UNIVERSIDADE DE SÃO PAULO

FACULDADE DE FILOSOFIA LETRAS E CIÊNCIAS

HUMANAS

DEPARTAMENTO DE HISTÓRIA

PROGRAMA DE PÓS-GRADUAÇÃO EM HISTÓRIA

ECONÔMICA

\author{
FÁBIO ROGÉRIO CASSIMIRO CORREA
}

\title{
Os Bancos de Custeio Rural e o crédito agrícola em São Paulo (1906-1914)
}

Versão revisada

São Paulo 
HUMANAS

DEPARTAMENTO DE HISTÓRIA

PROGRAMA DE PÓS-GRADUAÇÃO EM HISTÓRIA ECONÔMICA

\section{Os Bancos de Custeio Rural e o crédito agrícola em São Paulo (1906-1914)}

Fábio Rogério Cassimiro Correa

Dissertação de mestrado apresentada junto ao Programa de Pós-Graduação em História Econômica da Universidade de São Paulo (versão revisada).

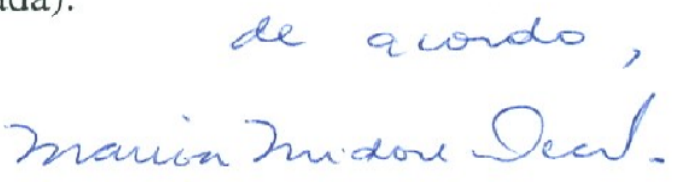

Orientadora: Profa. Dra. Marisa Midori Deaecto.

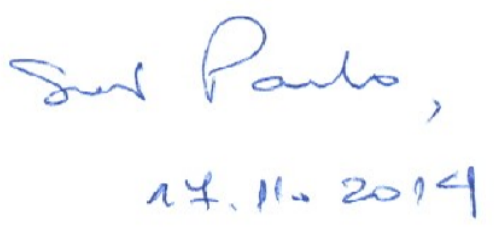

São Paulo 
UNIVERSIDADE DE SÃO PAULO

FACULDADE DE FILOSOFIA LETRAS E CIÊNCIAS

HUMANAS

DEPARTAMENTO DE HISTÓRIA

PROGRAMA DE PÓS-GRADUAÇÃO EM HISTÓRIA

ECONÔMICA

\section{Os Bancos de Custeio Rural e o crédito agrícola em São Paulo (1906-1914)}

Fábio Rogério Cassimiro Correa

Dissertação de mestrado apresentada junto ao Programa de Pós-Graduação em História Econômica da Universidade de São Paulo (versão revisada).

Orientadora: Profa. Dra. Marisa Midori Deaecto.

São Paulo 
A minha esposa, Claudia nosso filho,

Luiz Francisco, e a meus pais, Francisco e Maria 
Esta pesquisa foi financiada com recursos da FAPESP Processo $n^{0}$ 2011/16209-0 


\section{Sumário}

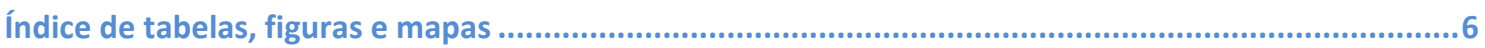

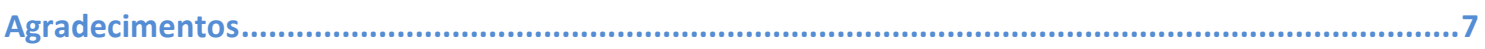

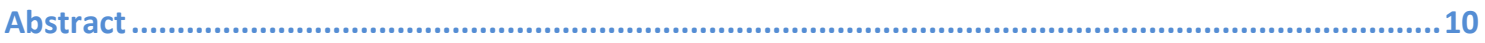

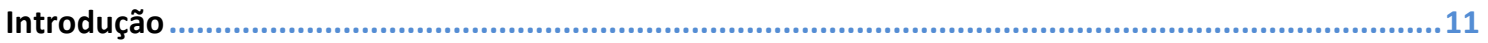

1. A evolução dos agentes do crédito e dos mecanismos de financiamento na economia cafeeira ......16

1.1. O problema do financiamento diante da expansão da cafeicultura escravista................. 16

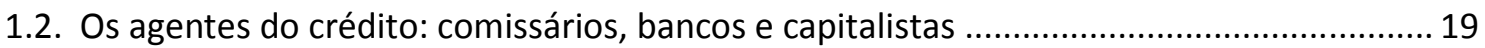

1.3. Os mecanismos de financiamento: a letra de câmbio e a hipoteca ............................... 31

1.4. A crise da cafeicultura escravista e seus efeitos sobre o sistema de financiamento......... 39

1.5. O trabalho livre e as transformações no sistema de financiamento ............................... 43

1.6. Novos mecanismos: reforma da lei de hipotecas, o penhor e o warrant .......................50

1.7. Muito além do comissário: um crédito multifacetado e hierarquizado .......................... 56

2. Crise econômica e crise política: a dinâmica dos conflitos no interior do complexo cafeeiro ...........63

2.1. A dinâmica do capital no complexo cafeeiro paulista................................................6 68

2.2. Poder oligárquico e capital cafeeiro............................................................ 71

2.3. A conformação do poder oligárquico: o PRP a e suas dissidências ................................. 80

2.4. Pela Lavoura: a disputa pelas associações de fazendeiros ....................................... 86

2.4.1. A Associação dos Lavradores Paulistas de 1896 ................................................... 88

2.4.2. Os clubes da lavoura e a constituição do Partido da Lavoura ................................ 93

2.4.3. A constituição da Sociedade Paulista de Agricultura e o papel das comissões

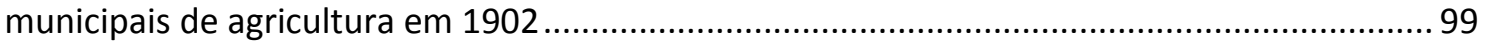

2.5. O PRP rumo ao congraçamento ................................................................... 102

3. O sindicalismo agrário e a origem do cooperativismo de crédito no Brasil................................107

3.1. Difusão do cooperativismo de crédito na Europa................................................. 108

3.2. Agrarismo: fusão dos sindicatos agrícolas com as caixas rurais ............................. 113

3.3. Sindicalismo rural e cooperativas de crédito no Brasil .............................................. 119

3.4. O catolicismo social e seu papel na difusão do cooperativismo de crédito no Brasil........121

3.6. O cooperativismo de crédito em São Paulo ............................................................ 125

4. Os Bancos de Custeio Rural ............................................................................................ 129 
4.1. A trajetória do projeto idealizado por Jacintho de Barros em 1899.

4.2. O surgimento da Sociedade Incorporadora e a aprovação da lei 1.062 em 1906.

4.3. Organização da Sociedade Incorporadora e dos Bancos de Custeio

4.4. Modo de operação e a atuação dos Bancos de Custeio Rural ............................................ 149

4.5. Os empréstimos concedidos pelos BCRs

4.7. Os Bancos de Custeio e a Sociedade Incorporadora dentro do sistema bancário paulista162

Conclusão

Fontes...

Referências bibliográficas

Anexo I- Discussão a respeito das fontes utilizadas na pesquisa. 
Tabela 1: Créditos concedidos entre 1896 e 1814 em Casa Branca, por ocupação dos credores (contos de réis)

Tabela 2: Quadro de acionistas da Sociedade Incorporadora em agosto de 1906

Tabela 3: Composição acionária da Sociedade Incorporadora em 1914 (em contos de réis)

Tabela 4: Empréstimos realizados pelos Bancos de Custeio Rural em 1907

Tabela 5: Recursos levantados com o Britsh Bank no exercício 1907/8

Tabela 6: Forma de financiamento pelos BCRs (réis)

Tabela 7: Operações de crédito realizadas pelos BCRs em 1910 (mil réis)

Tabela 8: Empréstimos concedidos pelos 20 Bancos de Custeio auxiliados e fiscalizados pelo governo (mil réis)

Tabela 9: Total de depósitos nos BCRs em 1910 (mil reis)

Tabela 10: Provisão de recursos em junho de 1908 (réis)

Tabela 11: Movimentação da Sociedade Incorporadora em dezembro de 1913

Tabela 12: Relação da Incorporadora com terceiros em janeiro de 1914

Figura 1: Modelo de sistema de financiamento da cafeicultura em São Paulo

Figura 2: Distribuição geográfica dos Bancos de Custeio Rural em 1913

Figura 3: Anúncio do Banco de Custeio Rural de Ribeirão Preto

Figura 4: Anúncio do Banco de Custeio Rural de Jaboticabal

Figura 5: Cheque sacado contra a Sociedade Incorporadora pelo BCR de Caçapava

Figura 6: Funcionamento em conjunto: Sociedade Incorporadora, 168 Bancos de Custeio Rural e mercado de letras de câmbio 
É com muita satisfação que escrevemos esses agradecimentos, não apenas porque estamos finalmente depositando nossa dissertação, mas principalmente porque nos possibilita lembrar da trajetória árdua que percorremos até finalização do texto. Ao longo desses anos tivemos a fortuna de encontrar pessoas extraordinárias que muito nos ajudaram, incentivando ou apontando nossas deficiências e que foram indispensáveis para conclusão desta dissertação.

Agradeço primeiramente à Profa. Dra. Marisa Midore Deaecto que nos acolheu no mestrado em História Econômica e foi sempre muito solícita, competente e paciente com nossas dificuldades. Agradeço também ao Prof. Dr. Lincoln Ferreira Secco que nos orientou na iniciação científica e nos apresentou à professora Marisa.

Agradeço à Profa. Vera Lúcia Amaral Ferlini, pois não poderia deixar de lembrar que foi na oficina de projetos de pesquisas, realizada no curso de História Econômica, durante a graduação que começamos a definir nosso objeto de pesquisa. Agradeceço especialmente ao Prof. Dr. Flávio Azevedo Marques de Saes, que desde 2010 nos atendeu com muita paciência, prontidão e generosidade, incentivando, lendo nossos manuscritos e nos auxiliando no levantamento de questionamentos sobre nosso objeto de pesquisa.

Agradecemos ainda ao Conselho Nacional de Desenvolvimento Científico e Tecnológico e ao Fundo de Amparo à Pesquisa do Estado de São Paulo pelo financiamento que nos foi concedido para realização da pesquisa.

É indispensável também agradecer aos professores que ministraram as disciplinas que frequentamos durante o curso de mestrado. Os Professores Doutores Alexandre de Freitas Barbosa, Nelson Nozoe, Rodrigo Ricupero, este último, ofereceu a seus alunos um raro espaço para o debate de seus projetos de pesquisa, ocasião na qual fomos prestigiados com as observações e questionamentos dos colegas Roberto Pereira, Carlos Tadeu, Idelma, Tiago e Cristiano Abreu. Agradeço especialmente ao Prof. Dr. Alexandre Saes, pelas oportunidades que criou para que pudéssemos expor nossa pesquisa.

Acumulei nestes últimos anos uma dívida impagável com diversos funcionários de arquivos sem os quais não teríamos acessado a documentação utilizada nesta dissertação. Este é o caso do Joaquim, funcionário do cartório da $2^{\text {a }}$ Vara Cível e do Jonas, funcionário do Fórum João Mendes, além do Paulo e da Cristina do Arquivo Geral do Judiciário. Agradecemos ainda os funcionários das bibliotecas Florestan Fernandes, 
assim como da Faculdade de Direito da USP, do Museu Republicano de Itu, do Instituto de Estudos Brasileiros, do Arquivo do Estado e do Museu Histórico de Jaboticabal.

Gostaria também de agradecer algumas pessoas que cruzaram nosso caminho nos últimos anos e sem as quais não podemos imaginar qual teria sido o resultado deste trabalho. Trata-se do Prof. Dr. Luiz Fernando Saraiva, que nos apresentou, ainda durante a graduação, a vários mecanismos de pesquisa e também pelas madrugadas que passamos discutindo o tema desta pesquisa, conversas nas quais me brindou com inteligentes soluções e inúmeros questionamentos para os problemas que se nos apresentava. Também o Prof. Dr. Renato Leite Marcondes, a quem agradeço pela atenção e generosidade em compartilhar informações que nos foram muito úteis. Lembramos ainda mais uma vez do professor Alexandre Saes, pela amizade e pelas leituras que fez de nosso trabalho, quase sempre em momentos críticos. Temos também uma dívida enorme para com os professores Rita Almico e Nelson Nozoe, pela leitura crítica que fizeram de partes de nosso trabalho, este último, como comentarista de nossa apresentação na IV Conferência Internacional de História Econômica \& VI Encontro Nacional de Pós-Graduação em História Econômica, ocorrido em 2012.

Agradecemos ainda a Gilmar Machado e Ivanil Nunes pelo companheirismo e a Cristiano Addario de Abreu e Rodrigo Fontanari, Juan Lucas Gómez com quem pudemos discutir intensamente os pontos nos quais nossas pesquisas se entrecruzavam.

Por fim, gostaria de manifestar toda a minha gratidão para com a minha querida esposa, Claudia, que teve enorme paciência nos momentos de angústia, apoiando-nos ao longo desses anos. 
Resumo

O sistema de financiamento da cafeicultura evoluiu no processo da transição do trabalho escravo para o livre, ocasionando o aumento da demanda do crédito para o custeio anual da safra sobre os empréstimos de longo prazo exigidos durante o regime escravista. Por outro lado, a crise dos preços do café ocorrida entre 1896 e 1906 evidenciou as limitações do sistema de financiamento existente que estava baseado nos adiantamentos fornecidos por comerciantes. As novas necessidades de crédito e o crescente clima de descontentamento com os mecanismos comerciais de financiamento acabariam por suscitar propostas de intervenção do Estado com políticas de crédito agrícola a serem organizadas ou subsidiadas pelo governo do Estado de São Paulo e que viriam a ser concretizadas na esteira do programa de valorização do café, adotado em 1906. Tais intervenções incluiriam a criação de bancos agrícolas e o incentivo às cooperativas rurais de crédito, das quais os chamados Bancos de Custeio Rural são os primeiros experimentos desse tipo no estado e constituem nosso objeto de estudo. Os Bancos de Custeio Rural formaram uma rede de cooperativas de crédito, que atuou entre 1906 e 1914 no interior do estado de São Paulo. Esses bancos emprestavam apenas aos fazendeiros associados o valor demandado no financiamento anual da lavoura. Tendo surgido no contexto da crise cafeeira de 1896-1906, a sua reconstituição revela o intenso debate a respeito dos meios de se combater a crise e sobre o papel do Estado no financiamento agrícola. Os bancos de custeio surgiram como uma alternativa à intervenção governamental no sistema de crédito e representam a primeira experiência com o cooperativismo de crédito no Estado de São Paulo. Em 1914, eles estavam presentes em quarenta e nove cidades paulistas, no entanto, apesar de seu rápido crescimento, eles desapareceram após a falência da companhia que os organizava, em janeiro deste ano. Neste artigo discutimos as circunstâncias de seu surgimento, sua organização, atuação e falência.

Palavras-chave: Crédito Agrícola - Café - Caixas rurais - Cooperativas - Cooperativas de crédito 


\section{Abstract}

The financing system of coffee has evolved in the transition from slave to free labor process as credit for the cost of the annual harvest was imposed in relation to long-term loans required by the slave system. On the other hand, the crisis in coffee prices that occurred between 1896 and 1906 would demonstrate the limitations of the funding system, based on advances provided by merchants. The new credit requirements and the growing sense of discontent with commercial financing mechanisms would eventually raise proposals for state intervention through an agricultural credit policy to be organized by the state government of São Paulo and that was to be carried on the mat the coffee valorization program adopted in 1906. Such interventions include the establishment of agricultural banks and encouraging rural credit cooperatives of which the so-called Costing rural banks are the first experiments of this type in the state and constitute our object of study. The "Bancos de Custeio Rural" consisted of a network of credit unions that operated between 1906 and 1914 in the state of São Paulo. During this period, these banks lent, to associated farmers only, the necessary amount to fund their annual crop. Having arisen in the context of the coffee crisis of 1896-1906, their reconstitution reveals the intense debate regarding ways to tackle the crisis and the role of the state in agricultural finance. The BCRs emerged as an alternative to government intervention in the credit system and represented the first experience with the credit cooperativism in the state of São Paulo. In 1914, they were present in forty-nine cities of that state. However, despite its rapid growth, they disappeared as soon as the company that have organized them went bankrupt, in January of that same year. In this article, we discuss the circumstances of its emergence, organization, operations and bankruptcy.

Key words: Agricultural Credit - Coffee - Rural Banks - Credit Cooperatives 


\section{INTRODUÇÃOO}

O objetivo deste trabalho é reconstituir a atuação de uma rede de cooperativas de crédito agrícola que atuou no interior do estado de São Paulo entre 1907 e 1914. Esses bancos cooperativos seguiam o modelo das caixas rurais Raiffeisen, instituições de caráter confessional que surgiram na Alemanha em meados do século XIX e se expandiram para o restante do continente, obtendo grande sucesso na França e na Bélgica após a década de 1890. Esta modalidade de cooperativa foi introduzida em São Paulo com a denominação de Bancos de Custeio Rural e resulta de intensos debates a respeito do sistema de financiamento da cafeicultura e das medidas reivindicadas pelos cafeicultores paulistas para no combate à crise cafeeira (1896-1906).

Esses pequenos bancos constituem uma das primeiras experiências com associações de crédito mútuo no Brasil e, ao mesmo tempo, representam uma das primeiras tentativas de implementar um sistema de financiamento específico ao custeio agrícola, em que sua organização teve impulso com a aprovação da Lei $n^{0} 1.062$, de 29 de dezembro de 1906, que autorizava o governo paulista a emitir títulos da dívida pública às primeiras dez cooperativas que organizadas segundo determinadas características e organizadas por uma companhia chamada Sociedade Incorporadora. A Incorporadora fomentou e articulou a criação de uma rede de 48 bancos distribuídos pelos principais centros produtores de café do estado e que chegaram a responder por uma importante parcela do crédito bancário concedido entre 1910 e 1913, entretanto, desapareceram rapidamente após a falência da sociedade que os organizara, em janeiro de 1914.

Pretendemos demonstrar que a compreensão do processo que levou à criação desses bancos passa necessariamente pela análise do contexto econômico e político do estado de São Paulo durante a chamada crise cafeeira, ciclo de baixa dos preços do café que perdurou de 1896 a 1906, além dos mecanismos de financiamento disponíveis à agricultura exportadora no período. Ao final do período politicamente conturbado que se seguiu à queda dos preços do café, os poderes políticos do estado de São Paulo colocariam em prática uma série de medidas destinadas a combater tanto os efeitos econômicos da crise como os problemas políticos por ela suscitados e que seriam resolvidos conjuntamente em meados de 1906.

$\mathrm{Na}$ esfera política a pacificação política foi alcançada pelo chamado congraçamento, uma política de aproximação posta em prática pelo núcleo dirigente do Partido Republicano Paulista, que visava incorporar ao comando do partido as forças 
dissidentes e opositoras que desde 1896 ameaçavam a hegemonia política PRP com a criação de um partido oposicionista, o Partido da Lavoura. $\mathrm{O}$ acordo final seria selado durante o congresso do PRP, reunido em maio de 1906, quando foi pactuada a divisão do controle do partido e sua acomodação no governo paulista. Como resultado desse processo, as principais forças políticas do estado uniram-se em torno da candidatura de Albuquerque Lins para a presidência do estado de São Paulo e a do mineiro Afonso Pena para o comando da República. Na esfera econômica, ocorreria um processo paralelo de negociações que acabou fazendo com que o governo tomasse medidas econômicas combatidas pelo comando do PRP desde o início da crise, como as reivindicações a respeito de intervenção "anticíclicas", que tinha como principal eixo a valorização do café, mas que envolvia também questões referentes à legislação trabalhista, à divisão de terras e, principalmente, à questão do crédito agrícola. As medidas intervencionistas mais conhecidas foram a aprovação do Convênio de Taubaté, em fevereiro de 1906, e a execução do Plano de Valorização, em novembro daquele mesmo ano. Entretanto, também faz parte desse mesmo processo a criação de uma política sistemática de aprovisionamento de crédito agrícola pelas instituições semioficiais como os Bancos de Custeio Rural e o Banco de Crédito Hipotecário e Agrícola do Estado de São Paulo (BCHAESP).

Os Bancos de Custeio Rural estavam organizados como caixas de crédito cooperativo e tinham por objetivo atrair depósitos provenientes da poupança dos colonos e permitir aos pequenos e médios fazendeiros o acesso ao crédito bancário - concentrado na capital paulista e disponível apenas aos maiores fazendeiros. A utilização desses empréstimos era limitada aos gastos anuais para a manutenção do cafezal e à colheita, modalidade de financiamento denominada custeio e cujas operações deveriam ser garantidas pelo penhor da safra. De maneira complementar aos Bancos de Custeio Rural, o governo paulista iniciou as negociações com um grupo de investidores franceses que organizariam, em 1909, o BCHAESP; este banco, por sua vez, atenderia a outra demanda específica de crédito - o capital para investimento e o financiamento de grandes fazendeiros - representada pelos empréstimos de maior valor e longo prazo concedidos através da emissão de letras hipotecárias.

Nossa pesquisa abrange uma parte desse processo com a reconstituição dos Bancos de Custeio Rural e teve início ainda durante a graduação em História e prosseguiu na pós-graduação. Ela foi dividida inicialmente em duas partes, na primeira delas, 
realizamos um levantamento da bibliografia que tratou da economia cafeeira, com ênfase para a cafeicultura paulista, quando analisamos obras clássicas com o objetivo de identificar as discussões a respeito do tema do financiamento, depois passamos à leitura de obras mais específicas sobre o crédito. O objetivo dessa parte da pesquisa era inserir nosso objeto em um quadro mais amplo e fazer uma análise de como o tema do financiamento fora abordado pela historiografia da economia cafeeira. Outra parte do trabalho consistiria na organização de um corpo documental que nos permitisse reconstituir a atuação dos Bancos de Custeio Rural: identificando os debates a respeito de sua criação e possíveis divergências em torno de seu projeto, além de discutir sua importância para o desenvolvimento da cafeicultura, quantificar suas operações e analisar as causas e as repercussões de sua falência em 1914.

Era assim que planejávamos a realização desta pesquisa, quando da apresentação de nosso projeto em 2011. Porém, ao longo do trabalho, tanto as novas leituras que fizemos como nas discussões que tivemos a oportunidade de participar na presença de colegas do Programa de Pós-Graduação em História Econômica e no contato com professores que nos honraram com críticas e sugestões, acabamos identificando a necessidade de ampliar a complexidade das análises, dada a especificidade de nosso objeto que exigia, por exemplo, uma compreensão mais detalhada do funcionamento do sistema de crédito e das demandas de financiamento da produção agroexportadora, assim como nos faltava uma compreensão de conjunto entre a dinâmica de reprodução da economia cafeeira e a dinâmica das disputas políticas ocorridas na primeira República.

Desse modo, além de reconstituir a operação dos Bancos de Custeio Rural, foi necessário reconstituir, por meio de pesquisa bibliográfica, o modelo de funcionamento do sistema de financiamento da cafeicultura, o que foi realizado no capítulo primeiro, em que procuramos apresentar a problemática do financiamento agrícola e os agentes e mecanismos utilizados na concessão do crédito, além de demonstrar as transformações pelas quais passou o sistema de financiamento após a adoção do trabalho livre e a repercussão que sobre ele pesou a crise cafeeira; reconstituindo-se, assim, o próprio contexto em que surgiram os Bancos de Custeio Rural.

No segundo capítulo, buscamos discutir conjuntamente os efeitos econômico e políticos da crise cafeeira com base na bibliografia a respeito do processo de reprodução da economia cafeeira e da dinâmica do processo político no estado. Posteriormente, por uma pesquisa em periódicos, obras políticas contemporâneas e documentação dos 
poderes executivo e legislativo, buscamos demonstrar o acirramento do conflito político entre 1896 e 1903 e como o discurso oposicionista passou a se articular em torno da questão da crise, principalmente as divergências entre aqueles que apoiavam a intervenção do governo no mercado cafeeiro e no sistema de crédito e aqueles que repudiavam a intervenção sobre a visão de que a economia encontraria na própria crise os remédios para sua superação.

No terceiro capítulo, $O$ sindicalismo agrário e a origem do cooperativismo de crédito no Brasil, buscamos descrever com base em bibliografia brasileira, francesa e espanhola a expansão do cooperativismo na Europa, analisando mais detalhadamente o cooperativismo agrícola de crédito. Esse capítulo está dividido em duas partes, na primeira delas, abordamos o surgimento das caixas rurais sob o modelo Raiffeisen e os bancos populares do tipo Schulze-Delitzsch na Renânia e na Prússia, em meados do século XIX; posteriormente, abordamos o contexto da crise agrária das últimas décadas do século para demonstrar o surgimento de movimentos agrários de tendência católica e antiliberal em vários países europeus e como esse movimento buscou se organizar em associações agrícolas e sindicatos rurais responsáveis pela disseminação de caixas rurais do modelo Raiffeisen. Posteriormente, abordamos a assimilação dos métodos do agrarismo francês no Brasil, principalmente pela Sociedade Nacional de Agricultura (SNA) que, em conjunto com associações de católicos leigos, lograram a aprovação do Decreto n. 979, de 6 de janeiro de 1903, que autorizava o funcionamento de sindicatos agrícolas e que constitui a primeira legislação brasileira sobre cooperativas. Por fim, demonstramos como no estado de São Paulo, o conflitante ambiente político e a postura cautelosa do governo determinou a organização de um tipo específico de cooperativa de crédito, com o subsídio à organização de instituições destituídas do teor doutrinário e do caráter classista e beneficente do cooperativismo sindical católico, constituindo-se em instituições de caráter mais utilitário, aproveitando-se dos benefícios econômicos desse tipo de organização.

No quarto capítulo, realizamos a reconstituição da atuação dos Bancos de Custeio Rural para qual utilizamos um corpo documental que começamos a captar e analisar ainda durante a graduação e que discutiremos mais adiante. Esse capítulo está dividido em sete partes, na primeira narramos a trajetória do projeto de criação dos Bancos de Custeio Rural, desde a concepção inicial de Jacintho Ferreira da Silva Barros que, em 1899, tentara organizar a Caixa Agrícola de Jaboticabal até a transformação do seu plano no 
Projeto de Lei $n^{0} 40$, de 1903. Posteriormente, analisamos a tramitação desse projeto e a aprovação da Lei $\mathrm{n}^{0} 1.062$, 29, de dezembro de 1906, e a criação da Sociedade Incorporadora. Em seguida, descrevemos o modo de funcionamento formal dos Bancos de Custeio Rural e da Sociedade Incorporadora. Procedemos, depois, à quantificação das operações dos Bancos de Custeio Rural e à reconstituição do modo como eles funcionavam na prática e interpretamos em conjunto as operações realizadas entre fazendeiros associados, bancos de custeio, Incorporadora e o mercado paulista de crédito. 


\section{A EVOLUÇÃO DOS AGENTES DO CRÉDITO E DOS MECANISMOS DE FINANCIAMENTO NA ECONOMIA CAFEEIRA}

O objetivo deste capítulo é discutir pesquisas que analisaram a cafeicultura e abordaram as relações de crédito e o financiamento para demonstrar a evolução dos agentes envolvidos no financiamento da cafeicultura, assim como dos mecanismos utilizados na concessão do crédito.

\subsection{O problema do financiamento diante da expansão da cafeicultura escravista}

Para que se possa discutir a evolução dos agentes e os mecanismos de concessão de crédito na economia cafeeira, gostaríamos de retomar a distinção feita por Wilson Cano sobre os complexos produtivos formados no Rio de Janeiro e em São Paulo ao longo do século XIX, o "complexo cafeeiro escravista" e o "complexo cafeeiro capitalista". O primeiro diz respeito ao sistema produtivo articulado em torno do porto do Rio de Janeiro, estreitamente vinculado ao trabalho escravo, abrangendo, principalmente, os municípios do sul do Rio de Janeiro e norte de São Paulo - região conhecida como vale do Paraíba. O segundo, diz respeito ao complexo articulado a partir do Porto de Santos e que incluía uma vasta região denominada genericamente de "oeste paulista", onde se obteve maior sucesso na introdução do trabalho livre e observou-se uma acelerada ampliação da produção durante as décadas de crise do escravismo ${ }^{1}$.

Por se tratar de um cultivo perene, as plantações de café exigiam um período de maturação que variava entre quatro a cinco anos e só a partir de então produziam plenamente. Esse fator contribuía para manter elevada a demanda por crédito de longo prazo para instalação das lavouras. Por outro lado, o regime de trabalho escravo tendia a agudizar essa dependência em relação ao crédito de longo prazo, visto que a aquisição de escravos representava uma imobilização de recursos que somente poderia ser amortizada ao longo de vários anos de produção. Além disso, o baixo volume de investimento na produtividade do solo e do trabalho impunha um caráter transitório às plantações, que fazia com que a fronteira agrícola se mantivesse em constante movimento, deixando para trás os solos desgastados e formando, constantemente, novas fazendas em zonas ainda inexploradas.

${ }^{1} C f$. Wilson Cano, "Padrões de diferenciação das principais regiões cafeeiras (1850-1930)". Estudos Econômicos, vol. 15, nº 2, p. 291-306,1985. 
A ampla literatura que abordou a cafeicultura escravista demonstrou que os escravos representavam o elemento de maior valor das propriedades, superando, como se demonstra nos inventários, o valor das terras, cafezais e benfeitorias dos proprietários fundiários. Desse modo, enquanto a compra de escravos era responsável pela demanda elevada de crédito de longo prazo, era esse mesmo escravo que fornecia a maior parte da garantia aos empréstimos, não as terras. Esta, por sua vez, tinha o seu valor determinado pela quantidade de escravos que empregada e pela idade dos cafezais plantados. Era o trabalho vivo e o trabalho morto transformados em renda capitalizada que definiam o valor das fazendas e o lastro dos empréstimos, esta característica da cafeicultura escravista determinará o desmoronamento do sistema de crédito durante a década de 1880, quando os cafezais se encontrariam envelhecidos e os escravos na eminência de serem libertados.

O crédito de longo prazo, como veremos a seguir, obtinha-se principalmente por meio da hipoteca, fornecido por prestamistas particulares e, em raras exceções, por instituições bancárias. Uma vez instalada a unidade produtora escravista era preciso alimentar e vestir os escravos, adquirir ferramentas e utensílios que eram fornecidos pelo comércio do Rio de Janeiro. Esse gasto realizado para manter o andamento da produção durante o ciclo anual era chamado de custeio e no sistema produtivo que se formou no vale do Paraíba, os fazendeiros obtinham os recursos para custeio por intermédio de comissários de café sob a forma de adiantamento contra a safra a ser-lhe entregue para comercialização.

O crédito para custeio distinguia-se do crédito para investir e implementar as lavouras porque requeria prazo menor, prazo que geralmente não ultrapassava a conclusão do ciclo produtivo, e era obtido mediante o aceite de letras de câmbio entre fazendeiros e agentes comissários, apesar da possibilidade do envolvimento de outros intermediários.

Entre os meados das décadas de 1870 e 1880 a produção cafeeira no vale do Paraíba apresentava-se em decadência e diversos autores que abordaram o tema destacaram o envelhecimento dos cafezais e a desagregação do regime escravista, que contribuía para a desarticulação das relações de crédito constituídas durante o auge da cafeicultura escravista. O sistema de comercialização e financiamento da cafeicultura 
passaria então por uma profunda crise que foi retratada opor autores como Stanley Stein, John Schulz e Marieta de Moraes Ferreira².

Com a transição para o trabalho livre e a expansão da lavoura no "oeste paulista" as condições de financiamento se alterariam significativamente, pois, enquanto a desconfiança em relação ao futuro da cafeicultura escravista causava restrição do crédito, a necessidade de se remunerar os trabalhadores aumentava a demanda por crédito de curto e médio prazo para o custeio da produção, o que por sua vez requeria novos mecanismos de financiamento para além da letra de cambio e da hipoteca.

No que diz respeito ao regime de exploração da mão de obra e sua relação com o modo como de dava o financiamento da lavoura, é preciso lembrar que o regime de trabalho adotado nas novas zonas produtivas do estado de São Paulo misturou três formas de remuneração num único contrato de trabalho. Conhecido como colonato, este contrato abrangia os principais trabalhos que deveriam ser realizados pelas famílias de colonos ao longo do ano, desde a limpeza dos cafezais até a colheita. Este contrato previa o pagamento de um valor mensal que estava oficialmente relacionado a carpa periódica do cafezal; a cessão de uma faixa de terra para o cultivo do colono (cultivo que servia para obtenção direta de meios de subsistência e para a venda de excedentes); além do pagamento de uma quantia em dinheiro ao final da safra, em função do volume de café colhido pelas famílias de colonos.

Com a demanda de recursos migrando das inversões de longo prazo para o custeio da safra tornara-se necessário desenvolver novos mecanismos jurídicos que garantissem o pagamento dos adiantamentos. A principal reivindicação do comércio comissário neste sentido era a melhoria do processo de execução das dívidas hipotecárias e a constituição do penhor dos frutos pendentes, o chamado penhor agrícola, o que foi conseguido pela aprovação da lei de execuções de 1885, que, na prática, era uma reformada da própria legislação hipotecária que vigorava desde 1865. Esta lei reforçava o processo de execução e criava uma nova garantia que se apresentava mais adequada ao financiamento de curto e médio prazo.

\footnotetext{
${ }^{2}$ Cf. FERREIRA, Marieta de Moraes, A crise dos comissários de café do Rio de Janeiro, Niterói, UFF (Dissertação de Mestrado), 1977; STEIN, Stanley J, Grandeza e Decadência do Café no vale do Paraíba, São Paulo, Brasiliense, 1961; SCHULZ, John, A crise financeira da abolição 1875-1901, São Paulo, Edusp, 1996.
} 
Esse sistema, como veremos a seguir, foi muito importante para manter o controle dos comissários de café sobre o financiamento da cafeicultura e, como consequência, o controle sobre o fluxo das mercadorias comercializadas. Entretanto, a dependência em relação ao crédito comercial se mostraria ainda um problema aos fazendeiros, principalmente nas quadras de crises. Enquanto os preços estavam em alta e o intermediário tinha interesse em fazer passar por suas mãos a maior quantidade possível de mercadoria, os adiantamentos eram fartos. Porém, ao longo de 1895, a notícia de que os preços despencariam na próxima safra causou uma grave retração. Quando veio finalmente a safra, as casas exportadoras já haviam comprado o café diretamente no interior dos estados, dispensando a intermediação dos comissários. Pagando à vista e até concedendo adiantamentos, os exportadores tinham margem para negociar a diminuição dos preços com os fazendeiros, tidos por recursos para pagar a colheita.

Em meados do século XIX, a economia e a sociedade brasileiras passam por uma série de transformações que marcam a sua inserção na nova ordem do comércio internacional, transformado pelo desenvolvimento das economias industriais - sobretudo da Inglaterra. São marcos desse processo, além da perseguição do padrão ouro a partir de 1846, a proibição do tráfico de escravos, a aprovação da Lei de Terras e o Código Comercial, ambos de 1850. Durante o primeiro ciclo de preços, entre 1857 e 1868, o vale do Paraíba era a principal zona cafeeira do país e o município de Vassouras constituírase como o principal centro produtor daquela zona. Na passagem do primeiro para o segundo ciclo de preços, o vale do Paraíba atingia o auge de sua produção. Segundo Stanley Stein, a expansão rápida da cafeicultura sob regime escravista assentava-se em três fatores: abundância de terras virgens, disponibilidade de escravos e recursos financeiros adquiridos, principalmente, por meio do crédito.

\subsection{Os agentes do crédito: comissários, bancos e capitalistas}

Na década de 1850 ocorreu uma série de transformações que contribuíram para fortalecer o papel centralizador da praça comercial e financeira do Rio de Janeiro em detrimento das demais praças do Império. Em primeiro lugar, o café produzido na província fluminense havia deslocado o açúcar como principal produto da pauta de exportações. As atividades de financiamento e a comercialização da safra desse produto eram coordenadas a partir da praça mercantil do Rio de Janeiro. Naquele mesmo período 
a proibição do tráfico atlântico revertera de maneira positiva para vários setores da economia na medida em que uma parcela dos capitais até então imobilizados no comércio de escravos refluiu para as praças comerciais do Império, possibilitando a formação de novos negócios, como bancos, firmas de seguros e diversos empreendimentos comerciais de grande porte.

Esses capitais liberados do tráfico foram fundamentais para a expansão das atividades bancárias no Rio de Janeiro. Paralelamente, em 1853, foi concedido o monopólio sobre emissões de moeda ao Banco do Brasil, o que contribuiria para concentrar as atividades financeiras do império em sua capital. As emissões realizadas pelo Banco do Brasil forneciam a liquidez necessária para o funcionamento de inúmeras casas bancárias que ofereciam o desconto dos títulos de crédito que circulavam no comércio. Desse modo, as casas comerciais do Rio de Janeiro se beneficiaram amplamente da oferta de crédito disponibilizado por esse sistema de crédito centralizado na capital do império, e constituía-se no elemento que permitiu a concentração do comércio atacadista do império naquela praça.

O funcionamento desse sistema pode ser resumido da seguinte forma: as firmas comerciais recebiam como pagamento letras de câmbio a prazo que podiam ser descontadas nas diversas casas bancárias existentes. Estas, por sua vez, redescontavam esses títulos com o Banco do Brasil, que graças ao privilégio de emissão estava capacitado para funcionar como emprestador de última instância.

Os diversos endossos conferiam credibilidade às letras de câmbio lastreadas na responsabilidade compartilhada entre os diversos agentes. Por sua vez, o Banco do Brasil redescontava apenas títulos com endosso de comerciantes que constavam de um cadastro de correntistas. Esta era uma maneira de conferir a solvabilidade dos títulos, mas que acabaria alçando tais comerciantes no patamar de liquidez superior ao dos demais, contribuindo para a concentração comercial. Assim, embora as letras de câmbio fossem emitidas e descontadas por qualquer pessoa, tornara-se indispensável que elas recebessem o endosso de um comerciante cadastrado no Banco do Brasil. Por outro lado, esse mecanismo articulado pelo Banco do Brasil permitiria à rede bancária atrair o imenso movimento das letras de câmbio, vales e notas promissórias que circulavam no comércio. Esse ambiente de negócio possibilitou a disseminação das atividades bancárias e contribuiu para a concentração das atividades comerciais e o fortalecimento dessa praça mercantil perante as demais praças do império. 
Até por conta disso um dos principais debates econômicos ao longo de todo o segundo império foi a questão do monopólio das emissões, conferido ao Banco do Brasil e a controvérsia em torno da conversibilidade em ouro das notas bancárias, o que interessava não apenas ao capital britânico, mas também aos banqueiros e comerciantes de grosso trato da praça mercantil do Rio de Janeiro, que estavam em condições de atrair maior quantidade do metal precioso graças à importância de seu comércio importador e exportador, mas que limitava a disponibilidade de crédito no restante do império.

O desenvolvimento desses mecanismos influenciaria diretamente o modo como eram realizadas as atividades de financiamento e comercialização do café, como veremos a seguir. Ao longo da década de 1850 ocorreu um processo de centralização e especialização do comércio comissário de café e a sua participação como principal agente financiador da cafeicultura do Vale do Paraíba.

Stanley Stein, ao descrever a origem dos recursos empregados pelos primeiros plantadores de Vassouras, afirmara que eles o haviam acumulado em outras atividades como o comércio ou haviam recorrido aos empréstimos com familiares, fazendeiros vizinhos e capitalistas locais. Os capitalistas, aliás, representavam uma fonte constante de recursos nas localidades. Esses indivíduos que se especializavam na concessão de empréstimos mantinham, por sua vez, relações com casas comissárias do Rio de Janeiro que os ajudavam na cobrança de dívidas contraídas por fazendeiros da localidade:

A maneira mais segura de cobrar uma dívida era fazê-lo por intermédio do comissário do fazendeiro no Rio. Mantinham os Teixeira Leite contatos íntimos com os grupos comerciais da Capital, onde membros da família tinham participação em casas comissárias ${ }^{3}$.

No início, os comissários concediam crédito aos fazendeiros apenas de maneira esporádica e, com o tempo, eles se especializaram nessa atividade e por volta da década de 1850 se consolidara no fornecimento de adiantamentos, deixando de lado a triangulação com indivíduos locais ${ }^{4}$.

Segundo Marieta Moraes Ferreira, até a década de 1850, havia uma miríade de pequenos comerciantes e negociantes que atuavam na comercialização do café e que se encarregavam de transferir a safra para os exportadores localizados no porto do Rio de Janeiro. A maioria desses agentes intermediários era composta por negociantes que com

\footnotetext{
${ }^{3}$ STEIN, 1961, op. cit., p. 21.

${ }^{4}$ Idem, pp. 20-23.
} 
o evoluir das lavouras, abriram casas, alugaram armazéns para guardar e vender seus gêneros no mercado ${ }^{5}$, operando com o comércio de consignação a partir de pequenos portos localizados no recôncavo da Guanabara ${ }^{6}$. Muitos desses receptadores eram, por exemplo, trapiches, que armazenavam café e diversas outras mercadorias e comercializavam pequenas quantidades sob consignação ou por conta própria. Esses agentes chegavam a até mesmo a conceder adiantamento aos depositantes ${ }^{7}$. Outros negociantes eram simplesmente comerciantes de secos e molhados estabelecidos no Rio de Janeiro que, ao manterem contato com varejistas nas localidades, recebiam o café que seus clientes fazendeiros lhes forneciam em troca de diversas mercadorias ${ }^{8}$.

Com a expansão dos negócios e o fortalecimento das relações entre firmas comerciais e casas bancárias, diversos comerciantes que atuavam até então com casa de secos e molhados, armazéns, trapiches, etc., especializaram-se no comércio de café, passo a passo agrega daqui desagrega dacolá, fez-se o comissário ${ }^{9}$ composto pelas grandes firmas tão características do comércio cafeeiro, que operando a partir do Rio de Janeiro, substituíram rapidamente as pequenas casas de consignação localizadas no recôncavo ${ }^{10}$. Além de negociar o café que lhes era remetido, faziam voltar pelas mesmas tropas de mulas uma infinidade de mercadorias para o abastecimento das unidades produtoras.

Posteriormente, entre essas firmas e as casas exportadoras estrangeiras surgiria outra classe de intermediário, o ensacador, responsável pela preparação e armazenamento do produto para a venda ao exportador.

O resultado desse processo de concentração do comércio sob comissões foi a estruturação de um sistema de financiamento das unidades produtoras que se baseava na liquidez fornecida pelas casas bancárias. A íntima relação entre essas grandes firmas comissárias e as casas bancárias existentes no Rio de Janeiro possibilitou ao comércio comissário assumir o financiamento das safras, o que até então era feito apenas de modo

\footnotetext{
5 JORDAO, Carlos A. de, “A Ação dos comissários de café” in: O Café no segundo centenário de sua introdução no Brasil. Rio de Janeiro: Dep. Nacional do Café, 1934, pp. 458-9.

${ }^{6}$ Cf. FERREIRA, 1977, op. cit.

${ }^{7}$ KUNIOCHI, Marcia Naomi. "Crédito, especulação e acumulação nos negócios mercantis. Rio de Janeiro: 1842-1857”. História e Economia: Revista Interdisciplinar (BBS), v. 4, n. 2, p. 199-220, 2008.

${ }^{8}$ Para a localidade de Capivary, na baixada fluminense, Hebe Mattos demonstrou que as vendas da região aceitavam gêneros agrícolas como farinha de mandioca, arroz, milho, feijão e café na liquidação das contas correntes dos proprietários, que por sua vez eram repassadas em lotes consolidados para atacadistas de secos e molhados do Rio de Janeiro, também em liquidação de contas. Cf. MATTOS, H. M.

9 JORDAO, op. cit, p. 459.

${ }^{10}$ FERREIRA, op. cit., pp. 10-11.
} 
esporádico. Esse novo papel do comércio comissário permitiu, por sua vez, o fortalecimento do vínculo entre fazendeiro e seu comissário, vínculo que garantia ao fazendeiro o financiamento da safra e ao comissário as remessas de café ${ }^{11}$.

Por outro lado, o relativo estado de isolamento no qual se mantinham a maioria dos fazendeiros fazia do comissário um importante elo com o Rio de Janeiro. Como era por meio desses agentes que se realizava a venda do café, eles também se ocupavam de vários serviços financeiros como a realização de pagamentos, cobranças e a remessa dinheiro para localidades onde também tivessem atuação. Desse modo, as casas comissárias tenderam a centralizar todas as operações comerciais e financeiras dos fazendeiros, funcionando como uma espécie de correspondente bancário ${ }^{12}$. Suas operações funcionavam na base da conta corrente, onde, de um lado se registravam o produto das vendas de café e, de outro, o valor dos gêneros remetidos pelos comissários, os pagamentos que realizavam por conta dos comitentes, a sua comissão e os juros que recaíam sobre os saldos. Na medida em que o comissário conseguia manter as despesas dos fazendeiros adstritas ao seu fluxo de caixa, a liquidação dos saldos em conta corrente demandava um volume mínimo de moeda.

Lembremos mais uma vez que foi o acesso das firmas comissárias ao crédito bancário que lhes permitia concentrar o comércio do café ${ }^{13}$.

Embora a maioria dos trabalhos sobre a cafeicultura tenha focado o papel do comissário de café como "o banqueiro dos fazendeiros", existiam outras fontes de crédito às quais os fazendeiros costumavam recorrer nas localidades. Um agente, cuja atuação só muito recentemente vem sendo desvendada, é o capitalista. Indivíduo que nas localidades emprestavam dinheiro a juros e que em diversos documentos aparecem também financiando a dívida pública de municípios e também como detentores de títulos do tesouro nacional. Nos recenseamentos do século XIX e também nas listas de qualificação de eleitores do império, o capitalista aparecia como uma qualificação profissional, por sinal, a dos mais abastados eleitores de São Paulo ${ }^{14}$. Além disso, grande parte da legislação sobre crédito fazia referência direta aos capitalistas enquanto agentes do

${ }^{11} C f$. STEIN, op. cit., 1961; FRANCO, op. cit., 1974.

${ }^{12} C f$. STEIN, op. cit., 1961.

${ }^{13} \mathrm{Cf}$. FAORO, op. cit., p. 417; FERREIRA, 1978, op. cit., pp. 12-15 e pp. 20-25.

${ }^{14}$ MAGALHÃES, Wanda Moreira, Eleitores e eleitosos agentes do poder em Campinas, na segunda metade do século XIX. São Paulo, 1992. 
crédito $^{15}$. Os almanaques do século XIX e também os do início do século XX dão ampla cobertura sobre sua presença nas mais diversas localidades.

Rui Barbosa, em seu relatório à frente do Ministério da Fazenda em 1890, ofereceu-nos uma descrição aproximada do papel do capitalista naquela sociedade, distinguindo-o da instituição bancária, desde que esta concedia empréstimos com os recursos captados de terceiros, enquanto o capitalista emprestava os recursos provenientes de sua própria acumulação ${ }^{16}$. No entanto, diversas pesquisas que abordaram o crédito hipotecário em localidades específicas apontam o capitalista como um intermediário entre o capital bancário e a clientela de fazendeiros e comerciantes nas localidades. Alguns indivíduos, por conta de sua importância política ou econômica, obtinham acesso privilegiado ao crédito hipotecário de origem bancária, como os fornecidos pela Carteira Hipotecária do Banco do Brasil ou pelo Banco de Crédito Real de São Paulo. Ao mesmo tempo, esses indivíduos, quase sempre grandes fazendeiros e chefes políticos, concentravam o fornecimento de empréstimos por meio de contratos particulares aos demais proprietários da localidade, como fora observado por Renato Leite Marcondes, em Lorena e Guaratinguetá, e por Rodrigo Fontanari, em Casa Branca ${ }^{17}$.

Nas poucas descrições historiográficas a respeito da atuação do capitalista, ele aparece como fornecedor de capital, em geral, com garantia hipotecária. O empréstimo hipotecário, por sua vez, tinha natureza diversa dos adiantamentos que caracterizavam a operação dos comissários. Eles estavam relacionados aos gastos mais elevados como as melhorias na propriedade, reposição de escravos ou mesmo expansão das unidades produtoras, enquanto os adiantamentos sobre a safra futura vinculavam-se diretamente à cobertura dos gastos de custeio. Aparentemente, os fazendeiros entravam em relação com capitalistas para obter recursos que não eram possíveis de serem obtidos pelo fluxo de caixa com os comissários, ou quando não lhes interessava condicionar a entrega do café aos adiantamentos. Embora os autores que analisaram a atuação dos comissários demonstrem que eles também se tornavam credores hipotecários, o que de fato

15 O Art. 10, do Decreto n. 3.272, de 5 de outubro de 1885, dizia o seguinte: "Os Bancos e sociedades de crédito real, e qualquer capitalista, poderão também fazer empréstimos aos agricultores [...]”.

${ }^{16}$ BARBOSA, Ruy. Obras completas de Rui Barbosa (V. XVIII Tomo II, Relatório do ministro da Fazenda), Rio de Janeiro: Ministério de Educação e Saúde, 1949, p. 40.

${ }^{17}$ MARCONDES, Renato Leite, "O financiamento hipotecário da cafeicultura do Vale do Paraíba Paulista (1865-1887)", Revista Brasileira de Economia, v. 56, n. 1, p. 147-170, JAN-MAR, 2002; FONTANARI, Rodrigo, O Problema do Financiamento: uma análise histórica sobre o crédito no complexo cafeeiro paulista. Casa Branca (1874-1914), Franca: Unesp (Dissertação de Mestrado), 2010. 
caracterizava a sua forma de atuação era o adiantamento e esses empréstimos de longo prazo estavam relacionados à consolidação de dívidas não liquidadas pelo fluxo de caixa.

A atuação do capitalista parece que esteve ligada muito mais relacionada às operações em dinheiro de valores elevados do que às transações por meio de letras de câmbio e aos demais sucedâneos monetários, embora seja possível também que tivessem participação na comercialização da safra.

No que diz respeito aos empréstimos entre particulares, a historiografia apresenta muitos indícios de que tais relações eram muito disseminadas na sociedade brasileira, isto pelo menos até as primeiras décadas do século XX. Sua importância foi constatada nas pesquisas com inventários post mortem, como os trabalhos de Rita de Cássia Almico ${ }^{18}$, Maria Lucília Viveiros de Araújo $^{19}$ e o clássico trabalho de Zélia Maria Cardoso de Mello $^{20}$. Além da tese de doutorado de Maria Luiza Ferreira de Oliveira, na qual a autora demonstrou serem tais relações muito presentes nos mais variados estratos sociais ${ }^{21}$.

O trabalho de Zélia Maria Cardoso de Mello, que analisou inventários post mortem de fazendeiros paulistas da segunda metade do século XIX, havia demonstrado uma tendência de diminuição dos escravos na composição da riqueza legada, principalmente a partir da década de 1870. A autora constatava, ao mesmo tempo, o aparecimento de títulos mobiliários, tais como ações, apólices e debêntures, que indicariam uma transformação no próprio modo de reprodução daquela economia ${ }^{22}$. Entretanto, o volume das "dívidas ativas" na composição da riqueza permaneceria elevado até o fim do período analisado. Por "dívidas ativas" denominavam-se os créditos concedidos em vida pelo falecido e que ele deixara a seus herdeiros e a autora não pode deixar de se mostrar surpresa com o alcance daquele tipo de relação de crédito em uma sociedade que já conhecia a instituição bancária:

Outro item que nos chama atenção dado seu percentual elevado no período todo é o dívidas ativas; nos almanaques elaborados no século XIX $(1857,1873,1883)$ e que contém informes preciosos sobre as pessoas e as profissões, as atividades, etc., em São Paulo, aparecem muitos indivíduos sobre a rubrica 'capitalistas' ou

\footnotetext{
${ }^{18}$ ALMICO, Rita de C, Fortunas em movimento: um estudo sobre as transformações na riqueza pessoal em Juiz de Fora / 1870-1914, Campinas: Unicamp (Dissertação de Mestrado), 2001.

${ }^{19}$ ARAUJO, Maria Lucília Viveiros de, Os caminhos da riqueza dos paulistanos na primeira metade do oitocentos. São Paulo: Hucitec-FAPESP, 2006.

${ }^{20}$ MELLO, Zélia M. C. Metamorfoses da riqueza, São Paulo, 1845-1895. São Paulo: Hucitec, 1985.

21 OLIVEIRA, Maria L. Ferreira de, Entre a casa e o armazém: relações sociais e experiência da urbanização, São Paulo: Alameda, 2005.

${ }^{22}$ MELLO, 1985, op. cit.
} 
'capitalista e proprietário'. Ainda que não se possa precisar o significado destas categorias, supôs-se que os 'capitalistas' seriam os empresários e os que viviam de empréstimos a juros e os 'proprietários' os que viviam de imóveis urbanos de aluguel $^{23}$.

Cardoso de Mello sugeria que dado a ausência do crédito bancário ou dado seu pequeno desenvolvimento, algumas pessoas deveriam funcionar como emprestadores particulares de quantias significativas, possibilitando o giro do dinheiro necessário numa economia em mudança com constantes inovações ${ }^{24}$. O trabalho de Zélia Cardoso de Mello se conectava aos estudos de Flávio Saes que, alguns anos antes, havia demonstrado a presença de fazendeiros que atuavam como capitalistas à frente da incorporação de companhias de serviços públicos e bancos em São Paulo. Essas pesquisas despertaram, posteriormente, grande interesse pela atuação do capitalista.

Em um artigo publicado em 1985, Pedro Carvalho de Mello discutia que as formas de investimento estavam disponíveis aos fazendeiros de café no século XIX. Tal questionamento fora influenciado pelo trabalho recém-publicado de Joseph Sweigart, que havia realizado um estudo quantitativo com as matrículas de hipotecas do município de Vassouras. Sweigart constatou que cerca de $40 \%$ dos empréstimos concedidos provinham de fontes locais. Com base nas taxas observadas, Pedro Carvalho de Mello elaborou um quadro comparativo das opções de investimento naquele período, em que a aquisição de título, apólices da dívida pública, depósitos bancários e ações de companhia negociadas na bolsa do Rio de Janeiro e de Londres apareciam como alternativas aos empréstimos a juros. A abordagem de Carvalho de Mello foi uma das primeiras análises historiográficas a abordar o crédito sob o prisma do credor e tratando o crédito como uma forma de investimento ${ }^{25}$.

Esses trabalhos inspirariam diversas pesquisas posteriores sobre composição da riqueza na economia cafeeira, originando novas interpretações a respeito das relações de crédito na economia agroexportadora, em que, um dos mais importantes foi, sem dúvida, o trabalho de Renato Leite Marcondes. Esse autor realizou uma minuciosa pesquisa com inventários e escrituras cartoriais referentes ao município de Lorena, no Vale do Paraíba paulista, possibilitando mapear a origem e o destino do crédito na região, onde se destacava a importância do crédito entre particulares. As relações de crédito foram

\footnotetext{
${ }^{23}$ Idem ibdem, p. 90.

${ }^{24}$ Idem, ibdem, p. 92.

${ }^{25}$ MELLO, Pedro Carvalho de, "Os Fazendeiros de Café e o mercado financeiro e de Capitais, 1871/88". Estudos Econômicos, v. 14, n. 1, p.145-161, 1984.
} 
abordadas tanto pelo aspecto da demanda por financiamento da atividade produtiva como o aspecto do empréstimo enquanto uma das modalidades de investimentos que, por sua vez, concorria com os títulos mobiliários, os depósitos bancários, além da aquisição de terras e escravos. Marcondes constatou que a maioria dos empréstimos fora concedida por indivíduos da própria localidade, mais do que isso, estavam concentrados nas mãos de três capitalistas, que eram também os indivíduos mais ricos da localidade ${ }^{26}$.

Os resultados da pesquisa de Marcondes, somados às descrições da atuação de capitalistas em Lorena, realizadas por Affonso de Taunay e Motta Sobrinho, permite-nos fazer uma comparação com a atuação desse mesmo tipo de agente na localidade de Vassouras, a partir dos estudos de Taunay, Stein e Sweigart.

Para Vassouras, Stanley Stein descrevera a atuação de capitalistas-fazendeiros como uma das mais importantes fontes de crédito, função na qual se destacara Francisco José Teixeira Leite, que havia se estabelecido naquela região na década de 1830. Proveniente de uma família de comerciantes, o futuro Barão de Vassouras, era filho do Barão de Itambé, capitalista em Minas Gerais, e sobrinho de Custódio Ferreira Leite (Barão de Ayuruoca), importante negociante da Praça do Rio de Janeiro. Francisco José formou a fazenda Cachoeira com dinheiro emprestado do pai e, ao mesmo tempo, emprestava dinheiro aos vizinhos, atuando, no início, como uma espécie de correspondente do $\mathrm{pai}^{27}$.

É interessante notar que a descrição da atuação de Francisco José feita por Taunay em nada lembra a descrição comum do fazendeiro escravista:

Tão ativo quanto inteligente, organizado e poupado, fizera girar com prudência e atilamento as sobras que lhe deixava o café. Nunca estendia demais as lavouras conservando-se em justo termo prático. Mais tarde alargando suas operações fizera vezes de banqueiro, e, afinal, chegara a ter verdadeira casa bancária, quando o município de Vassouras se opulentava dia a dia, girando com capitais paternos e os de diversos parentes seus de Minas Gerais ${ }^{28}$.

O justo termo prático que limitava as plantações de Francisco José advinha, certamente, do fato de ele ser mais do que um fazendeiro, um capitalista, além disso, a casa bancária à qual Taunay se refere era nada menos que o Banco Comercial e Agrícola

\footnotetext{
${ }^{26} C f$. MARCONDES, Renato Leite, A arte de Acumular na economia cafeeira: Vale do Paraíba século XIX, Lorena, Stiliano, 1998, cap. VI.

${ }^{27}$ TAUNAY, A. de E., História do café no Brasil. Rio de Janeiro: Inst. Nacional do Café, 1941, v. 5, pp. 202-3.

${ }^{28}$ TAUNAY, op. cit., v. 5, p. 208.
} 
do Rio de Janeiro, um banco de emissão constituído em 1858 e que se fundiria ao Banco do Brasil em $1862^{29}$.

Voltando à sua atividade como capitalista, de acordo com a análise do inventário do Barão de Vassouras feita por Taunay, verifica-se que ele era credor de importantes fazendeiros da província do Rio de Janeiro como o Barão de Paty do Alferes e o Barão de Capivary. Ao todo, ele mantinha negócios com 198 pessoas, seus devedores, de maiores e menores quantias, quase todos os fazendeiros, cujos débitos orçavam por 1.047:996\$217 reis ${ }^{30}$. Segundo Stanley Stein, Teixeira Leite dispunha de agentes em outras localidades que lhes ajudavam nas execuções de dívidas, principalmente quando implicavam na adjudicação de propriedades. Por outro lado, afirma o mesmo autor: $a$ maneira mais segura de cobrar uma dívida era fazê-lo por intermédio do comissário do fazendeiro no Rio e este capitalista mantinha contatos íntimos com os grupos comerciais da Capital, onde membros da família tinham participação em casas comissárias. Esta última constatação parece indicar algum tipo de intermediação do capitalista das localidades em relação a firmas comissárias do Rio de Janeiro ${ }^{31}$. Em decorrência do falecimento de sua esposa, no ano de 1850, o Barão de Vassouras distribuiu a metade de ativos entre os filhos, mesmo assim, os balanços de seus haveres demonstrariam progressivo avanço a ponto de nas vizinhanças de 1870 acusarem perto de 3.600 contos de reis ou cerca de trezentas e sessenta mil libras esterlinas ${ }^{32}$. Para que possamos compreender o representava esta cifra é preciso lembrar que as 235 escrituras de hipotecas encontradas por Joseph Sweigart no registro de Vassouras, entre 1873 e 1884, somavam 4.441 contos de réis ${ }^{33}$.

Voltando agora ao município de Lorena, estudado por Renato Leite Marcondes, esse autor observa que a concessão de empréstimos na localidade estava concentrada nas mãos de três capitalistas, o Padre Joaquim Ferreira da Cunha, o comendador José Vicente de Azevedo e o seu concunhado, o comerciante Joaquim José Moreira Lima ${ }^{34}$.

\footnotetext{
${ }^{29}$ GUIMARAES, Carlos G., "O Império e o crédito hipotecário: o estudo de caso do Banco Commercial e Agricola 1858-1861", I Seminário Interno do Programa de Pós-Graduação em Desenvolvimento Socioeconômico, UFMA, 3 a 4 de junho de 2013.

30 TAUNAY, 1941, op. cit., v. 5, p. 208.

31 STEIN, 1961, op. cit., p. 21

32 TAUNAY, 1941, op. cit., v. 5, p. 208.

${ }^{33}$ Cf. SWEIGART, Joseph E. Coffee factorage and the emergence of a Brazilian capital market, 18501888. 1980. New York: Garland, 1987.

${ }^{34}$ MARCONDES, op. cit., 1998, pp. 236-240.
} 
Além de analisar os inventários, ele também quantificou as hipotecas registradas em Lorena, demonstrando que no período de 1866 a 1879 foram registrados 1.414:199\$018 em hipotecas, em que 62,9\% havia sido concedido por indivíduos da localidade e apenas 3,8\% por bancos. No período seguinte, o autor observou um aumento da participação de bancos do Rio de Janeiro na concessão de empréstimos sobre hipotecas e, entre 1880 e 1887, dos 2.269:554\$935 registrados, os prestamistas locais ainda concentravam a maior parte, $55,2 \%$, no entanto, os empréstimos bancários representavam $16,9 \%$ do total ${ }^{35}$. O papel dos prestamistas locais em Lorena parece ser ainda mais preponderante que o observado em Vassouras por Sweigart. Este último havia observado que $39 \%$ das hipotecas da localidade tinham bancos como beneficiários, enquanto $40,9 \%$ desses empréstimos foram concedidos por indivíduos da localidade, sendo 35,3\% por capitalistas e fazendeiros e 5,6\% por comerciantes; enquanto as casas comissárias eram responsáveis por 20,1\% ${ }^{36}$. Embora Sweigart houvesse ressaltado a importância do crédito bancário na localidade, e a comparação Lorena o confirmaria, em ambas o crédito concedido por agentes locais permanecia preponderante,

Segundo Marcondes, dos três capitalistas de Lorena, era Joaquim José Moreira Lima que havia adquirido maior destaque, assim como Teixeira Leite, em Vassouras, ele concedia empréstimos para além da sua localidade, alcançando os municípios de Areias, Bananal e Guaratinguetá, onde contava também com a ajuda de representantes. Motta Sobrinho, que também estudou essa família, mostrou que Moreira Lima emprestava dinheiro para além da fronteira provincial e, em 1864, ele era credor de produtores de fumo de Itajubá, Minas Gerais ${ }^{37}$. Diz Motta Sobrinho que:

O velho capitalista estimulava os sitiantes trabalhadores e honrados a se converterem em fazendeiros. Aos grandes ensejava, quando devedores, oportunidade de não saírem da posse de suas terras. O filho do Visconde de Guaratinguetá deve a essa generosidade não ter perdido, por cem contos de réis, a grande fazenda das Três Barras, com mais de cem mil alqueires, e que seria a base da fortuna de seus dois genros, os irmãos Virgílio e Francisco de Paula Rodrigues Alves ${ }^{38}$.

De acordo com Marcondes, Moreira Lima também costumava receber parte dos pagamentos em café e remetia o produto a um representante em Mambucaba, no litoral

\footnotetext{
${ }^{35}$ Idem, ibdem, p. 234.

${ }^{36}$ SWEIGART, 1987, op. cit.

${ }^{37}$ SOBRINHO, A. Motta, A Civilização do Café (1820-1920), São Paulo: Brasiliense, 1978, p. 76.

${ }^{38}$ Idem. Ibdem, p. 85.
} 
sul fluminense, que se encarregava de encaminhá-lo a firmas comissárias do Rio de Janeiro $^{39}$. Outra característica observada em Vassouras e que aparentemente se repete em Lorena é a organização familiar na atividade creditícia. Após a morte de Moreira Lima em 1879, seu filho, o conde de Castro Lima assumiu o controle dos créditos concedidos pelo pai, dando continuidade na mesma atividade ${ }^{40}$.

As pesquisas analisadas até agora dão conta de que o financiamento da cafeicultura escravista dera-se por meio dos adiantamentos concedidos por comerciantes de café e empréstimos de dinheiro fornecido por particulares. Comissário e capitalista aparecem como responsáveis por duas demandas distintas de crédito: os adiantamentos para custeio e o empréstimo de dinheiro para incremento e expansão da produção. No entanto, há relatos de empréstimos hipotecários concedidos por comissários e de capitalistas que atuavam como intermediários com as firmas comissárias. É possível, por outro lado, que os créditos hipotecários concedidos por comissários tivessem como finalidade não a manutenção da safra, aparecendo como forma de subsidiar as transações por meio de contas correntes. Por outro lado, exemplos que descrevem a ação de capitalistas com a firmas comissárias não parecem indicar uma atuação generalizada do capitalista como intermediário de firmas comissárias, como será observado mais tarde em relação aos comissários do porto de Santos. Tais relações aparecem em Stein como forma de obter liquidação de dívidas e, no caso de Marcondes, como fruto do recebimento de café como pagamento de juros e amortização dos empréstimos concedidos.

De qualquer modo, se é possível observar comissários concedendo empréstimos hipotecários e capitalistas recebendo habitualmente café como pagamento de dívidas, o adiantamento em conta corrente era o que caracterizava o financiamento concedido pelas casas comissárias, e o empréstimo de dinheiro a juros era o que caracterizava a atividade de capitalista, este último entendido como indivíduos que possuíam recursos ociosos para emprestar. Como o crédito entre particulares era uma operação amplamente disseminada, certamente muitos fazendeiros emprestavam regularmente a seus vizinhos, parentes e amigos. Entretanto, havia uma camada de indivíduos que embora atuasse em outras atividades, como fazendeiros ou comerciantes, especializou-se na concessão de empréstimos.

\footnotetext{
${ }^{39}$ MARCONDES, 1998, op. cit., pp. 243-4.

${ }^{40}$ Idem, ibdem., p. 245.
} 


\subsection{Os mecanismos de financiamento: a letra de câmbio e a hipoteca}

Uma vez definidos os agentes do financiamento da cafeicultura voltamo-nos para a caracterização dos mecanismos utilizados para a concessão dos empréstimos, neste ponto é fundamental analisarmos os papeis que exerciam dois mecanismos de financiamento bastante distintos: a letra de câmbio e a hipoteca.

A letra de câmbio é uma órdem de pagamento escrita, dada por alguém a uma terceira pessoa, para que esta pague, a quem estiver indicado naquela ordem como beneficiário a importância então fixada ${ }^{41}$.

Trata-se de um antigo meio de pagamento pelo qual se costumava processar as transferências de valores entre praças distantes que, embora inseridas num mesmo circuito mercantil, utilizavam diferentes padrões monetários. Sua origem é controversa e a literatura jurídica e histórica já a situou, por exemplo, na Índia, entre os fenícios, romanos e gregos. É sabido, entretanto, que ela adquiriu enorme importância no comércio mediterrânico por volta dos séculos XI e XII. Juridicamente a letra de câmbio é um instrumento onde uma pessoa devedora (sacador ou emitente), pretendendo liquidar uma obrigação ordena que uma segunda pessoa (sacado) pague determinada quantia a um terceiro indivíduo (beneficiário). A prática mercantil transformou a letra num título negociável no qual o seu beneficiário pode transmiti-la a outrem apenas assinando no seu verso, ato que o torna também responsável pelo seu pagamento e é denominado desconto. De desconto em desconto a letra circula até o seu vencimento e os endossos que recebe aumentam a teia de responsabilidades e definem sua credibilidade ${ }^{42}$.

A história desse título confunde-se com a própria história da atividade bancária e também com o comércio de mercadorias sob consignação ${ }^{43}$. Como exemplo, digamos que um comerciante de Gênova no século XIV precisasse remeter valores a uma outra praça do mediterrâneo, para tal operação ele deveria procurar um banqueiro, espécie de negociante especializado em operações de câmbio e lhe entregava determinado valor em moeda local, em contrapartida o comerciante recebia um escrito denominado littera cambii pelo qual ele se comprometia a pagar ao portador valor correspondente em uma praça determinada, onde um correspondete do banqueiro deveria realizar o pagamento em moeda local. Este correspondente entrava em contato com outros comerciantes que

\footnotetext{
${ }^{41}$ COSTA, Wille Duarte. Títulos de crédito, Belo Horizonte: 2005, p. 10.

${ }^{42} \mathrm{Cf}$. COSTA, Wille Duarte. Títulos de crédito, Belo Horizonte: 2005.

${ }^{43}$ KUNIOCHI, Marcia Naomi. "Crédito, especulação e acumulação nos negócios mercantis. Rio de Janeiro: 1842-1857”. História e Economia: revista interdisciplinar (BBS), v. 4, n. 2, 2008 pp. 199-220.
} 
precisavam fazer o circuito inverso. Posteriormente, a prática mercantil transformou a letra num título negociável, possibilitando que outros indivíduos especulassem com sua cotação. Assim, o beneficiário de uma letra não precisava mais esperar pelo seu vencimento, podendo trocá-la para obter antecipadamente os valores ali representados. $\mathrm{O}$ desconto dissimulava o juro do dinheiro, segundo Fernand Braudel, esta característica fez da letra de câmbio um dos mais importantes mecanismos de crédito durante a cristandade ${ }^{44}$. Braudel descreve o modo como um mercador de Medina del Campo realizava o comércio de câmbio entre cidades distintas por volta de 1590:

A velha raposa compra, na praça de sua cidade [Medina del Campo], letras de câmbio sacadas por produtores de lã espanhola que despacham para a Itália seus tosões e não querem esperar, para receber o dinheiro, os prazos do transporte e os pagamentos normais. Têm pressa de receber o que lhes é devido. Simon Ruiz adianta-lhes o dinheiro, contra uma letra de câmbio, em geral sacada contra o comprador de lã, pagável três meses mais tarde. Comprou, se possível, o papel abaixo do preço nominal e enviou-o ao amigo, comissário e compatriota, Baltazar Suárez, que mora em Florença. Este recebe o dinheiro do sacado, utiliza-o para comprar nova letra de câmbio, esta sobre Medina del Campo, que Simón Ruiz receberá três meses mais tarde ${ }^{45}$.

No Brasil, até a década de 1850 , as transações desse tipo eram reguladas pelo Tribunal da Real Junta de Comércio, Agricultura, Fábricas e Navegação, criado após a chegada da família real portuguesa. Com a publicação do Código Comercial surgia a primeira legislação completa sobre a operação com esses títulos no país ${ }^{46}$.

A emissão de letras de câmbio dispensava depósito inicial de fundos, deveria ter prazo de vencimento e podia ser transferida por simples endosso. O código fazia uma distinção entre a letra de câmbio propriamente dita - utilizada no comércio entre moedas distintas e a denominada "letra da terra" - que era, em quase tudo, idêntica à primeira com a única diferença de serem passadas e aceitas na mesma Província ${ }^{47}$. Na prática, ambas não diferiam uma da outra e eram chamadas letras de câmbio, ou simplesmente letras.

Para o Código Comercial qualquer compromisso escrito de pagamento que envolvesse um comerciante era considerado letra de câmbio para fins de execução, o Código não fazia distinção entre letra de câmbio (que envolve três indivíduos) da -

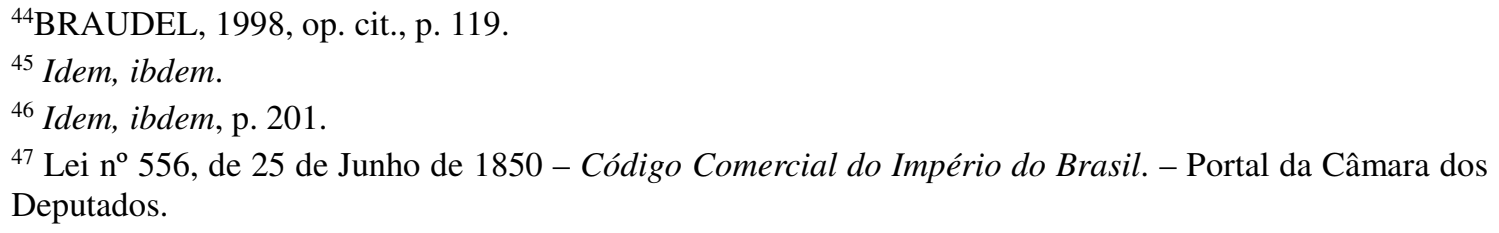


promessa simples de pagamento, também chamada "bilhete à ordem" ou "nota promissória", como fazia a legislação francesa, nem a distinguia da "carta de crédito", presente na legislação portuguesa do período. O que fazia da letra um titulo especialmente importante para a grande maioria das transações comerciais e operações de crédito era o fato de que, uma vez que ela envolvesse um comerciante, a sua execução dispensava processo executivo na justiça cível, valendo para fins de execução o simples protesto do não pagamento em cartório, passando a ter execução mais célere ao tramitar no juizado comercial.

Ao longo dos séculos de um instrumento próprio das transaçãoes internacionais a letra transformou-se em um mecanismo de crédito amplamente empregado no comércio interno dos países, como nos relata o seguinte diagnóstico de um jurista no início do século XX:

A cada classe, no comércio é familiar, em regra, certo número de vantagens que lhe dá a letra, mas são lhes estranhas as que ela liberaliza a outras classes. A casa comercial, que se entrega aos negócios de importação e exportação, o negociante de pequeno trato em praça minúscula, o indivíduo que especula no câmbio, o que remete dinheiro de praça a praça, o que busca capitais em momentos de angústia, não sabe senão de um limitadíssimo número de aplicações da letra.

O título de favor, a circulação anormal, a letra para caução, a que é garantida por hipoteca, a que nasce de uma mera relação cambial e a que provém de outras relações jurídicas preexistentes ou contemporâneas, acodem a interesses muito diversos, e não se regem, se não em parte, pelos mesmos princípios ${ }^{48}$.

No que diz respeito à cafeicultura, era a letra o elo que mantinha a rede de negócios envolvida no financiamento da lavoura cafeeira que incluía o fazendeiro de café, a casa comissária, a casa bancaria e o banco de emissão. Como lembrou Marcia Kuniochi a compreensão do funcionamento do circuito comercial e do próprio crédito bancário passa obrigatoriamente pela compreensão do papel central que letra de câmbio representava para $\operatorname{ambos}^{49}$.

A atuação dos comissários de café estava intimamente relacionada ao uso da letra de câmbio. Os haveres e deveres assinalados nos cadernos de conta corrente mantidos por fazendeiros e comissários eram acompanhados pelo aceite recíproco de letras que, ao final da safra, eram contrapostas. Como lembra Raimundo Faoro, o dinheiro entrava nesse sistema de contas apenas para liquidação do saldo resultante. As letras aceitas por

${ }^{48}$ ARRUDA, João, A letra de cambio actual, São Paulo: Siqueira, Nagel \& Comp., 1913, p. 4.

${ }^{49}$ KUNIOCHI, 2008, op. cit. 
fazendeiros eram sacadas por comissários e vice-versa e a presença da assinatura de um comerciante como sacador ou como endossante conferia maior credibilidade a esse título, permitindo seu desconto em casas bancárias ${ }^{50}$. Isto ocorria porque, em primeiro lugar, havia a sujeição do comerciante ao Código Comercial. Em segundo lugar, porque ele tinha a favor de seu crédito o receio de perder o registro na Junta de Comércio. Em terceiro lugar, o Banco do Brasil, instituição que dava liquidez ao circuito das letras de câmbio apenas redescontava as letras aceitas e endossadas por comerciantes previamente cadastrados e que mantinham relações com a instituição, de modo que as letras firmadas por tais indivíduos circulavam com maior facilidade e menor taxa desconto ${ }^{51}$.

Do modo como estava organizado o sistema bancário não era possível ao fazendeiro acessá-lo diretamente e os vários bancos que surgiram ao longo do século XIX com nomes que poderiam sugerir o atendimento à lavoura, tais como hipotecário, rural ou agrícola, nada mais eram do que bancos comerciais, ou seja, bancos de depósitos e descontos de letras. Esses bancos financiavam a atividade agrícola por intermédio da atuação de firmas comissárias, fosse aceitando letras em benéficos dos fazendeiros que, por sua vez, as utilizavam como meios de pagamentos, ou endossando letras aceitas por fazendeiros e redescontando-as nas casas bancárias ${ }^{52}$. Percebe-se desse modo como as transações por meio de letras de câmbio estão intimamente relacionadas ao circuito comercial e como o papel preponderante do desconto destas entre as atividades realizadas pelos bancos do período contribuíam para reforçar o papel do crédito comercial no financiamento da atividade produtiva.

Embora muitos autores tenham ressaltado o caráter arcaico do predomínio do crédito comercial na atividade agrícola brasileira, esse sistema era o que havia de mais moderno em se tratando de mecanismo de crédito, todo o sistema bancário inglês estava baseado nas transações com esse tipo de título, por outro lado, a participação do setor usurário-mercantil nos canais de financiamento era também um desafio para a agricultura da Europa continental durante o século XIX. A Alemanha resolveu primeiro esse problema com a criação de bancos territoriais que concediam empréstimos hipotecários de longo prazo e posteriormente com as caixas rurais, organizadas como cooperativas, e

$50 C f$. FAORO, op. cit.

${ }^{51}$ FERREIRA, 1978, op. cit., p. 22-5.

${ }^{52}$ LEVY, María Barbara; ANDRADE, Ana Maria de. Fundamentos do sistema bancário no Brasil: 18341860, Estudos Econômicos, v. 15, p. 17-48, 1985. 
que forneciam adiantamentos aos lavradores por meio do crédito pessoal. Instituições que depois seriam adotadas na França e, com intervalo de pouco mais de uma década, seriam também assimiladas no Brasil ${ }^{53}$.

O estabelecimento de bancos hipotecários para financiamento da lavoura fora, desde muito cedo, objeto de intensas discussões no império. Em 1848, Bernardo de Souza Franco publicou o trabalho Os Bancos do Brasil, Sua História, Defeitos da Organização Atual e Reforma do Sistema Bancário, uma das primeiras obras sobre crédito bancário produzidas no Brasil, em que apontava a necessidade de os bancos se ocuparem do financiamento da lavoura e, para tanto, defendia a realização de uma reforma da legislação hipotecária de modo que a propriedade pudesse servir de garantia, visto que a legislação em voga, herdada da colônia, não era capaz de conferir segurança jurídica à execução das dívidas hipotecárias, afastando, desse modo, os bancos dos empréstimos agrícolas. Naquele momento era impossível a um credor potencial saber se uma determinada propriedade já se encontrava onerada por hipoteca proveniente de empréstimos anteriores ou se recaíam sobre ela outros ônus como os obtidos por órfãos e pelo Tesouro, a chamada hipoteca legal. Nesse sentido, Souza Franco apontava que o sucesso de qualquer lei hipotecária dependia da possibilidade de se conferir publicidade às alienações ${ }^{54}$.

Além da publicidade das obrigações hipotecárias, a publicidade dos próprios títulos de propriedade constituía um grave problema para a concessão de empréstimos hipotecários. A Lei de Terras, de 1850, regulamentada pelo Decreto n. 1.318, de 30 de janeiro de 1854, obrigava todos os proprietários a registrar suas terras no registro paroquial. Porém, esse registro não solucionaria o problema da segurança dos títulos, principalmente porque não havia padronização das informações prestadas e porque, diante da ausência de autoridade cartorial nas localidades, eram os párocos que decidiam sobre a veracidade das informações, o que permitia que os registros fossem mais suscetíveis à influência do mandonismo local dos fazendeiros ${ }^{55}$. Em 1846, quase dez anos

\footnotetext{
${ }^{53}$ A reforma hipotecária francesa de 1850 teve por objetivo possibilitar a criação dos bancos territoriais tão bem-sucedidos nos Estados germânicos, por sua vez, ela inspiraria a lei hipotecária brasileira de 1864. No que diz respeito às caixas rurais, a implementação de tais instituições no Brasil fez-se de acordo com o modelo adotado na França, que, por sua vez, era inspirado nas caixas rurais alemãs. A respeito da lei hipotecária, veja: DURAND, Louis. Credit agricole en France et à l'etranger. Paris: Chevalier-Marescqet, 1891; WERNECK, Luis P. de Lacerda. Estudos sobre credito rural e hypothecario seguidos de leis, estatutos e outros documentos. Rio de Janeiro: Garnier, 1857.

${ }^{54}$ FRANCO, Bernardo de Souza. Os bancos do Brasil, Brasília: UNB, 1984, pp. 112-7.

${ }^{55}$ GARCIA, Graciela Bonassa, “Registros paroquiais de terras”, In: MOTTA, Marcia M. e GUIMARAES,
} 
antes do registro paroquial de terras, foi criado o Registro Geral de Hipotecas ${ }^{56}$, no entanto, como o registro era facultativo e como as hipotecas de terras e escravos deveriam ser registradas em locais diferentes, essa lei não resolveria o problema da publicidade dos ônus que pesavam sobre as propriedades.

A falta de segurança a respeito dos títulos de propriedade, assim como dos ônus que recaiam sobre ela, representava um sério problema para eventuais credores hipotecários. Esses dois problemas que caminhavam juntos seriam definitivamente resolvidos apenas com a lei hipotecária de 1864. Lei que criou o registro de hipotecas nas comarcas que substituíam os registros paroquiais e determinou que toda a transmissão de propriedade bem como os ônus que recaíssem sobre ela teriam validade apenas depois de registrados 57 .

A lei hipotecária, inspirada na reforma hipotecaria francesa de 1850, criou, além de um marco legal para a execução das hipotecas, uma nova forma de instituição de crédito e um novo mecanismo de concessão de empréstimos, a letra hipotecária emitida pelas chamadas sociedades de crédito real, similares aos bancos territoriais europeus como o Credit Foncier de France. Como a explicam Hanley e Marcondes:

A ideia era esta: bancos hipotecários aumentariam os fundos para empréstimos hipotecários vendendo estas letras aos investidores. As letras podiam ser nominativas ou ao portador e transmissíveis por simples endosso e seriam resgatadas pelo método determinado pelo banco, geralmente por loteria sobre uma escala prévia, eliminando a vulnerabilidade bancária a mudanças súbitas do mercado hipotecário ou nas condições econômicas fundamentais ${ }^{58}$.

Por volta de 1850 os bancos territoriais tinham mais de meio século de tradição nos Estados germânicos e neste período a legislação hipotecária francesa foi reformada para adequar-se a tais instituições, tendo sido criado o Credit Foncier de France, que adquiriu o monopólio sobre as operações hipotecárias. As discussões sobre a reforma da legislação hipotecária no Brasil refletiam diretamente os debates realizados na Assembleia Nacional francesa. Em 1854, Joaquim Nabuco apresentou ao Congresso uma

Elione (Org.), Propriedades e disputas: fontes para a história do oitocentos, Niterói: Eduff, 2011, pp. 6570; RODRIGUES, Pedro Parga, "Augusto Teixeira de Freitas e o Registro Geral de Imóveis no Império", Anais do XXV Simpósio Nacional de História, Anpuh, Fortaleza, 2009

${ }^{56}$ Lei $^{\circ} 317$, de 21 de outubro de 1843 e Decreto ${ }^{\circ}$ 482, de 14 de novembro de 1846.

${ }^{57}$ RODRIGUES, Pedro Parga, "A Lei Hipotecária de 1864 e a propriedade no XIX”, In: Anais do XIII Encontro de História Anpuh-Rio, Rio de Janeiro: UFRRJ, 2008.

${ }^{58}$ HANLEY e MARCONDES, 2007, op. cit., p. 4. 
proposta de lei hipotecária que provocou discussões que duraram uma década até a sua aprovação em 1864 e regulamentação em $1865^{59}$.

Em meados do século XIX, havia bancos hipotecários na maioria dos Estados germânicos, quase sempre com o monopólio sobre as operações de hipotecas em suas regiões e estavam constituídos em alguns Estados como associações de proprietários e, em outros, como associações de capitalistas. Suas letras tinham enorme credibilidade e grande aceitação entre os capitalistas, além de renderem juros, eram negociadas com ágio nas bolsas germânicas ${ }^{60}$. $\mathrm{O}$ surgimento de tais instituições contribuiu para institucionalizar a concessão de créditos hipotecários, permitindo que instituições bancárias substituíssem os prestamistas na concessão de crédito aos agricultores. Esses prestamistas deveriam substituir o investimento em empréstimos pela aquisição de letras hipotecárias, ficando os bancos territoriais encarregados pelos custos administrativos e de risco, adquirindo assim, uma alternativa segura de investimento ${ }^{61}$.

No Brasil, houve pouco interesse pela incorporação de sociedades de crédito real. A primeira a se constituir foi a Carteira Hipotecária do Banco do Brasil, criada em 1866, e que ganhou maior importância apenas em 1873, mas que encerrou suas operações em 1885 devido à proximidade da abolição ${ }^{62}$. A criação dessa carteira é reflexo direto da crise financeira de 1864 e marcou o fim do chamado "banco da ordem", termo utilizado por Thiago Gambi para se referir ao papel exercido pelo Banco do Brasil até aquele momento, atuando como executor da política monetária conservadora do império ${ }^{63}$. A Carteira Hipotecária foi assumida a contragosto pela diretoria do banco, que acabou aceitando-a mediante subsídios, mantendo ainda a sua carteira comercial de depósitos e descontos por onde financiava operações do comércio ${ }^{64}$.

Diante dos resultados restritos alcançados pelos bancos hipotecários, o governo imperial resolveu recorrer ao capital estrangeiro oferecendo subsídios à incorporação de sociedades de crédito real no Brasil, o que ocorreu a partir da Lei $n^{\circ} 2.687$, de 6 de

${ }^{59}$ NABUCO, Joaquim. Um estadista do Império, Nabuco de Araujo, sua vida, suas opiniões, sua época, por seu filho Joaquim Nabuco. Rio de Janeiro, Garnier, 1897, v. 2, pp. 120-5.

${ }^{60}$ WERNECK, 1857, op. cit., pp. 143-5.

${ }^{61}$ Idem, ibdem, pp. 27-8.

${ }^{62}$ SCHULZ, John, A Crise Financeira da Abolição 1875-1901, São Paulo, Edusp, 1996.

${ }^{63}$ GAMBI, Thiago Fontenlas Rosado, O banco da ordem: política e finanças no império brasileiro (185366), Campinas: UNICAMP (Tese de Doutorado), 2010.

${ }^{64}$ PIÑERO, Théo Lobarinhas, "A Carteira Hipotecária do Banco do Brasil: os conflitos em torno do Crédito Agrícola no II Reinado”. In Elione GUIMARAES e Márcia M. de M. MOTTA(orgs.). Campos em Disputa: História Agrária e Companhia, São Paulo, Annablume, p. 41-62, 2007. 
novembro de 1875 , pela qual o governo oferecia garantia de juros de $5 \%$ ao capital aplicado em uma sociedade de crédito real e mais garantia à remuneração das letras hipotecárias que fossem lançadas em praças estrangeiras ${ }^{65}$. A tentativa de atrair o capital estrangeiro ao financiamento hipotecário não obteve sucesso, segundo Rui Barbosa, o governo brasileiro procurou banqueiros e capitalistas ingleses e franceses, ouvindo dos primeiros que as letras, sendo garantidas pelo governo, concorreriam com os títulos do próprio governo que já negociados por eles naquela praça; obteve-se maior interesse por parte do Credit Foncier de France, porém este banco não consentia com as condições da lei, tais como limitação às hipotecas rurais, taxa máxima de $7 \%$, além dos prazos considerados excessivos e a obrigação de criar filiais ${ }^{66}$.

As letras hipotecárias emitidas pelo Banco do Brasil tiveram aplicação diversa das emitidas pelos bancos similares europeus, pois, ao invés de distribuí-las a bancos e capitalistas para captação de recursos, eram entregues aos próprios fazendeiros no lugar de moeda legal a fim de serem utilizadas como meios de pagamentos, enquanto que os juros e amortizações dos empréstimos devessem ser pagos em moeda legal. Uma explicação possível para esse modo de operação com as letras hipotecarias pode ser a ausência ou a restrição de um mercado de capitais que desse circulação a tais títulos. Entretanto, esta não os títulos da dívida pública encontravam enorme aceitação e, posteriormente, também as ações e de debêntures de companhia foram largamente observadas compondo o ativo de fazendeuiros e capitalistas do período. A utilização da letra hipotecária como meio de pagamento também foi observada no caso dos bancos de crédito real de São Paulo ${ }^{67}$ e Minas Gerais ${ }^{68}$, assim como pelo Banco de Crédito Hipotecário e Agrícola de São Paulo, este último iniciou suas operações em 1909 oferecendo apenas $5 \%$ do valor concedido em moeda legal.

Exceto pelas letras do Banco do Brasil, as letras dos bancos provinciais costumavam ser negociadas com deságio, o que significava que a taxa paga pelos empréstimos era muito maior que a nominal. Durante a crise da cafeicultura paulista

\footnotetext{
${ }^{65}$ Além do incentivo às sociedades de crédito real, essa lei também buscou animar o capital estrangeiro na instalação de Engenhos Centrais de açúcar no Brasil. Cf. MEIRA, R. B., Banguês, engenhos centrais e usinas: o desenvolvimento da economia açucareira em São Paulo e a sua correlação com as políticas estatais (1875-1941). São Paulo: Alameda, 2010.

${ }^{66}$ BRASIL, MINISTERIO DA FAZENDA. Relatorio do Ministro da Fazenda. Rio de Janeiro: Imprensa Nacional, 1891, p. 158-160.

67 BANCO DE CREDITO REAL DE SÃO PAULO. Relatorio que será apresentado á Assembléa dos accionistas convocada para 7 de maio de 1902. São Paulo: Duprat \& Comp., 1902.

${ }^{68}$ CROCE, M. Crises Financeiras na Primeira Década Republicana e os Bancos em Minas Gerais (1889 - 1903). Belo Horizonte: CEDEPLAR/UFMG (Tese de doutorado), 2013, p. 248.
} 
(1896-1906), os mutuários das sociedades de crédito real viram suas letras perderem valor rapidamente.

\subsection{A crise da cafeicultura escravista e seus efeitos sobre o sistema de financiamento.}

Em 1868, o mercado de café apresentava um novo ciclo de preços com um movimento de forte alta que se manteve até 1874. Este segundo ciclo de preços corresponde a um período de profundas transformações na economia brasileira, ao longo do qual se observa a rápida desagregação do regime escravista e o processo de decadência da produção cafeeira do Vale do Paraíba. Nesse período a historiografia da cafeicultura do vale ressaltou a expansão do crédito bancário, principalmente a partir de 1873 com a expansão dos empréstimos da carteira hipotecária do Banco do Brasil e do Banco Predial $^{69}$. Expansão que seria abortada logo em seguida pelo processo de decadência da cafeicultura do vale do Paraíba $^{70}$, na década seguinte, a desagregação do regime escravista e a abolição prejudicariam ainda mais a expansão dessa modalidade de crédito porque parte substancial do valor das fazendas era conferida pelo número de escravos que a tocavam.

Por outro lado, havia se iniciado o processo de formação de um mercado de capitais, centrado no Rio de Janeiro, e que teve início no fim da década de 1860 . O financiamento da Guerra do Paraguai impusera ao governo o aumento do déficit público a ser financiado pela emissão de apólices que, por sua vez, eram adquiridas por bancos e capitalistas. Ao mesmo tempo em que se difundia a aquisição de títulos públicos, ocorreu uma expansão extraordinária das sociedades anônimas e, em 1867, nada menos que 69 companhias tinham suas ações negociadas no país, cujo capital nominal atingia 108.003:217 $\$ 000^{71}$, para se ter uma ideia do que representava essa cifra, basta lembrar que o movimento total das exportações no ano 1866/7 fora de $156.020: 996 \$ 000^{72}$.

Na década de 1870, a confiança na lavoura cafeeira do Vale do Paraíba, que já se encontrava abalada pela decadência produtiva, tinha na promulgação da Lei do Ventre Livre (1871) um terrível golpe. O surgimento do mercado de capitais potencializava o problema do financiamento uma vez que as novas formas de aplicação do capital ocioso

\footnotetext{
${ }^{69}$ Cf. STEIN, 1961, op. cit.; SWEIGART, 1987, op. cit.

${ }^{70} \mathrm{Cf}$. SCHULZ, op. cit.

${ }^{71} C f$ MELLO, 1984, op. cit., p. 149.

${ }^{72}$ GRAZIERA, Rui G. A Guerra do Paraguai e o capitalismo no Brasil. São Paulo: Hucitec, 1979, p. 158.
} 
concorriam com os empréstimos concedidos a fazendeiros e que constituíam parte importante do financiamento agrícola ${ }^{73}$. Desse modo, uma situação trágica ia se delineando para o Vale do Paraíba ao longo da década de 1870: os fazendeiros se tornavam cada vez mais endividados e dependentes de mais crédito, seja para compra de escravos ou para substituir parte deles por máquinas de beneficiamento, enquanto os prestamistas ficavam cada vez mais receosos a respeito da liquidez dos fazendeiros ${ }^{74}$.

No Congresso Agrícola de 1878, um dos temas mais debatidos foi o problema do crédito. Os fazendeiros acusavam os bancos e os capitalistas de não lhes atenderem, de cobrarem taxas abusivas e de preferirem os títulos públicos. Por outro lado, os fazendeiros que estavam na condição de credores em relação aos demais reclamavam da falta de liquidez da lavoura e da dificuldade de execução das dívidas ${ }^{75}$. Um dos depoimentos do congresso ilustra bem a divisão de interesses no que dizia respeito ao crédito: os fazendeiros mais ricos [...] preocupavam-se com a segurança de seus ativos financeiros. Os menos abastados viam o sistema de financiamento fundamentalmente como um clube do qual eles estavam excluídos ${ }^{76}$.

Em resposta às reclamações dos fazendeiros, o ministro da fazenda, Cansanção de Sinimbu, comprometeu-se a reduzir a remuneração das apólices da dívida pública de $6 \%$ para $5 \%{ }^{77}$, o que evidencia o clima de insatisfação dos fazendeiros com os "desvios" do capital ocioso para a dívida pública. Além disso, não eram apenas os capitalistas que se viam atraídos pelas apólices, mas também os bancos; Carlos Gabriel Guimarães demonstrou que o Banco Rural e Hipotecário do Rio de Janeiro mantinha quase todo o seu ativo aplicado em apólices ${ }^{78}$.

A crise da cafeicultura escravista abalava de forma estrutural o sistema de financiamento erigido durante a década de 1850. O tradicional circuito de financiamento representado pela triangulação entre casa bancária - firma comissária - fazendeiro de café tivera a sua unidade abalada. Segundo Marieta de Moraes Ferreira, no fim da década de

${ }^{73}$ STEIN, 1961, op. cit., pp. 288 e 295.

${ }^{74}$ Idem, ibdem, pp. 271-280.

${ }^{75}$ Idem, ibdem, p. 256.

${ }^{76}$ SCHULZ, 1996, op. cit., p. 49.

${ }^{77}$ Idem, Ibdem, pp. 56-7.

${ }^{78}$ GUIMARAES, Carlos G. "O Banco Rural e Hipotecário do Rio de Janeiro e o pós-guerra do Paraguai, 1871-1875". Anais do V Congresso Brasileiro de História Econômica e $6^{a}$ Conferência Internacional de História de Empresas, ABPHE, 2003. 
1870, as casas comissárias do Rio de Janeiro começaram a enfrentar os efeitos da decadência, o que seria agravado pela queda dos preços no início da década de 1880 .

Uma vez que a confiança na lavoura escravista se via abalada, os bancos também passaram a exigir dos comissários garantias suplementares e elevaram as taxas de desconto. Ao ter de recusar o crédito a seus comitentes, as firmas comissárias não tinham mais como garantir as remessas de café, perdendo com isso o controle que exerciam sobre a comercialização do produto. Os fazendeiros, por sua vez, viam-se cada vez mais descontentes com os comissários.

Com a contração do crédito, desaparecia aquele vínculo que unia fazendeiro e comissário. Em anúncios pela imprensa carioca, os comissários apelavam a seus comitentes que tivessem paciência e que limitassem o saque de letras contra seus comissários a apenas o que fosse estritamente necessário ${ }^{79}$.

Ao mesmo tempo agitavam-se os ânimos na Capital do império em torno da questão da escravidão; em 1884, iniciavam-se as discussões que terminariam na aprovação da Lei do Sexagenário. Nesse momento era criado o Centro da Lavoura e do Comércio do Rio de Janeiro, órgão no qual o comissariado daquela praça oferecia combate ao movimento abolicionista e propunha a introdução de imigrantes chineses. Em setembro, era aprovada a lei do sexagenário e, no mês seguinte, a lei das execuções cíveis e comerciais ${ }^{80}$.

De acordo com Marieta de Moraes Ferreira a crise impôs a reorganização da atuação das casas comissárias. A impossibilidade de manter o financiamento das fazendas - pelo menos no mesmo nível como era feito desde 1850 - acarretava um afrouxamento dos laços que prendiam fazendeiros e comissários. Como resultado, o modo de comercialização do café teria passado por uma transformação com o aumento da concorrência pelo café adquirido no interior e o aparecimento de inúmeros intermediários

\footnotetext{
${ }^{79}$ FERREIRA, 1977, op. cit., p. 62.

${ }^{80} \mathrm{O}$ Centro da Lavoura e do Comércio do Café foi organizado pelos diversos clubes da lavoura que haviam se instalado nas diversas localidades para discutir a crise da cafeicultura e, segundo Marieta de Moraes Ferreira, esse órgão se propunha a fazer propaganda contra o abolicionismo e combater as fugas de escravos. Enquanto uma parte das reivindicações do Centro da Lavoura refletia interesses mais gerais da lavoura cafeeira, tais como a redução das tarifas ferroviárias, do imposto de exportação, a assinatura de tratados de comércio que permitissem a expansão do consumo mundial do café, a propaganda nos mercados consumidores e a imigração estrangeira - principalmente a chinesa. Outras refletiam interesses específicos que beneficiavam os credores da lavoura como comissários e capitalistas, estas propostas diziam respeito a uma reforma da legislação hipotecária que tornasse as ações hipotecárias executáveis pelo juízo comercial, apesar da hipoteca ser regida pela lei civil, o fim da adjudicação forçada e o estabelecimento do penhor agrícola. Cf. FERREIRA, 1977, op. cit., p. 65.
} 
entre os fazendeiros e as casas exportadoras e mesmo entre aqueles e as firmas comissárias: tornou-se frequente a abertura de agências no interior ou o envio de um agente, tendo ambos, o objetivo de adquirir novos clientes ou assegurar a fidelidade dos antigos. A concorrência entre as firmas comissárias pelas partidas de café vindas do interior era tamanha que mereceu menção de Van Delden Laerne, o botânico batavo que viajara ao Brasil para descrever as condições da produção e comércio do café brasileiro, tendo chamado tal prática de pescaria do cafée ${ }^{81}$.

Ao longo da década de 1880, todo o processo de comercialização do café foi alterado, levando à desconcentração do comércio comissário, com o surgimento de novos intermediários e a diversificação dos produtos negociados pelas firmas tradicionais do comércio cafeeiro. Invertia-se assim o modo de organização que havia sido estabelecido por volta de 1850, mediante a associação das firmas comissárias com o capital bancário da Praça do Rio de Janeiro.

As firmas comissárias, até então concentradas no Rio de Janeiro, passaram a deslocar seus agentes - que muitas vezes eram sócios da firma - pelas mais diversas regiões:

Expediente ainda mais simples, mas que funcionava com o mesmo objetivo, era a realização de sociedades com firmas comerciais do interior. Essa modalidade de negócio evitava muitos gastos e responsabilidades para o comissário, e auxiliava numa melhor arrecadação da produção ${ }^{82}$.

Outra modificação importante fora a diversificação das mercadorias negociadas por essas firmas, que passaram a realizar consignação de açúcar, algodão e cereais, além dos negócios com secos e molhados e importação e exportação. Algumas casas comissárias, as maiores, passaram a atuar diretamente com exportação de cafée ${ }^{83}$. Por outro lado, enquanto os comissários diversificavam suas atividades para se exporem menos aos sucessos da lavoura cafeeira, diversos comerciantes em geral aumentaram as suas transações com a lavoura, recebendo café em troca de produtos enviados aos fazendeiros, desde comerciantes de secos e molhados, armarinhos, ferragens, todos enfim que forneciam alguma coisa a crédito aos agricultores passaram a atuar um pouco como comissários $^{84}$.

\footnotetext{
${ }^{81}$ FERREIRA, 1977, op. cit., p. 82

${ }^{82}$ Idem, p. 83.

${ }^{83}$ Idem, p. 84-7

${ }^{84}$ Idem, p. 92
} 


\subsection{O trabalho livre e as transformações no sistema de financiamento}

De acordo com Delfim Netto, cada novo ciclo de preços do café era acompanhado por uma nova fase de expansão do consumo mundial e transformações na estrutura produtiva mundial. Desse modo, durante o segundo ciclo de preços, o consumo mundial de café havia saltado de 6,6 milhões de sacas em 1868 para atingir 11,5 milhões no ano de $1884^{85}$. Nesse período observou-se uma transformação no mercado consumidor com uma grande expansão do consumo nos Estados Unidos. A expansão do mercado norteamericano relacionava-se com o longo período de baixa dos preços, que se estendeu de 1874 a 1884, e também com o surgimento de indústrias torrefadoras, que passaram a vender o café torrado, moído e embalado em pequenos pacotes, o que facilitava o consumo doméstico. Ao mesmo tempo, ocorria uma importante transformação nas zonas produtoras, com a decadência da cafeicultura em Java, Ceilão e no vale do Paraíba ${ }^{86}$ concomitantes a expansão da cafeicultura no oeste paulista.

Diante dessa conjuntura negativa tanto a queda da produtividade no Vale do Paraíba (resultante da idade avançada dos cafezais) como a desagregação do regime escravista contribuíam mutuamente para a decadência da produção cafeeira nessa região. No oeste paulista, entretanto, a maior renda diferencial proporcionada pelos cafezais novos possibilitou aos cafeicultores manter o ritmo de expansão das plantações, enquanto, ao lado do braço escravo, incorporavam-se paulatinamente os trabalhadores livres, aumentando o volume da força de trabalho no mesmo ritmo em que a expansão da rede ferroviária ia incorporando novas zonas produtivas. Embora os preços estivessem em queda no mercado internacional, o mecanismo cambial havia permitido a manutenção de um ritmo lento de queda dos preços internos. Nesse mesmo movimento, a produção cafeeira do Vale do Paraíba era paulatinamente substituída pelo café produzido no oeste de São Paulo, sem que ocorressem sobressaltos no volume total exportado ${ }^{87}$.

No início da década de 1870, o escravismo se desagregava e tinha início o processo de substituição do braço escravo pelo livre, em que pese à população escrava da província de São Paulo ter aumentado entre 1872 e 1883, passando de 156.612 para 174.622 o número de cativos. Em 1886, entretanto, o número de escravos regredira para 160.665, mas diante de uma conjuntura favorável no mercado de café, a província logrou

\footnotetext{
${ }^{85}$ DELFIM NETTO, 1981, op. cit., p. 20.

${ }^{86}$ Cf. LACERDA, Joaquim Franco. Producção e Consumo de Cafe no Mundo. Situacao Economica e Financeira do Brazil. Questoes Economicas e Sociaes. São Paulo: Typ. Ind. de São Paulo, 1897.

${ }^{87}$ DELFIM NETTO, 1981, op. cit.
} 
receber um contingente de cerca de 50 mil imigrantes entre os anos 1875 e 1885 . Na segunda metade da década, a política de imigração subvencionada foi fundamental para estabelecer um intenso fluxo de trabalhadores estrangeiros, o que permitiu aos fazendeiros realizar a substituição completa do trabalho escravo e ainda ampliar o ritmo da expansão.

Durante os anos de depressão, São Paulo conseguiu atrair grande quantidade de escravos das outras províncias. Entre 1872 e 1883, o plantel de escravos aumentou de 156 para 174 mil $^{88}$. A alta produtividade nas terras novas de São Paulo havia permitido a introdução paulatina de trabalhadores estrangeiros, mantendo-se um ritmo constante de expansão da lavoura cafeeira. Quando teve início o terceiro ciclo de preços do café, em 1886, a população escrava fora reduzida para 160 mil. Nesse momento a produção paulista era estimulada pela crescente demanda do mercado mundial, e a ampliação da escala de produção foi mantida graças à manutenção de um fluxo de imigrantes que permitiu a entrada de 700 mil trabalhadores entre 1886 e $1896^{89}$. Em breve, o café exportado pelo Porto de Santos já excedia o volume de café escoado pelo Porto do Rio de Janeiro e, no início do século XX, o Porto de Santos escoava acima de $50 \%$ da produção mundial de café ${ }^{90}$.

Desde o início das discussões sobre a substituição do trabalho escravo pelo livre, que acompanhou os trabalhos em torno da proibição do tráfico de escravos, surgiram dois modelos de incorporação de trabalhadores imigrantes que constituíam tendências opostas. O governo imperial buscava o estabelecimento de núcleos de assentamento no interior, pois, como afirma Viotti da Costa, os objetivos de tal política eram, sobretudo, demográficos. Reconhecia-se a necessidade de povoar o país e, para isso, recorria-se à "colonização". O próprio termo colonização surgiu empregado no sentido de introdução e fixação de populações estrangeiras nas vastas áreas desocupadas do território nacional. Entretanto, diversas tentativas empreendidas no sentido de estabelecer núcleos de fixação fracassaram, reforçando a corrente oposta, representada por grandes produtores de café, pelos quais "afirmava-se que o país precisava de braços para a lavoura e não de núcleos

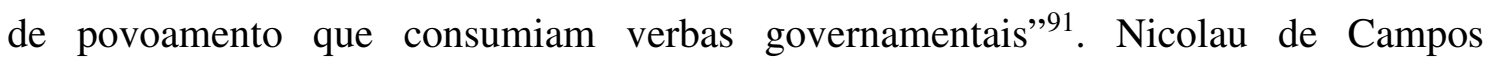

\footnotetext{
${ }^{88}$ COSTA. Emilia Viotti da. Da senzala à colônia. São Paulo: Liv. Ciências Humanas, 1982, p. 195-6

${ }^{89}$ SAO PAULO. Relatorio apresentado ao dr. Domingos Correa de Moraes Antonio Candido Rodrigues. Sao Paulo Secretaria da Agricultura. São Paulo: s/n, 1902.

${ }^{90}$ ARAUJO FILHO, José R. de. Santos, o Porto do Café. Rio de Janeiro: IBGE, 1969, pp. 171-5.

${ }^{91}$ COSTA, 1982, op. cit., p. 49.
} 
Vergueiro, importante fazendeiro e político do império, quando consultado, em 1827, sobre a possibilidade do estabelecimento de um núcleo colonial na província de São Paulo, apontou a "incompatibilidade entre esse tipo de colonização e o interesse dos proprietários"92.

Nas discussões em torno da Lei de Terras, aprovada em 1850, os legisladores brasileiros demostraram preocupação com o exemplo da colonização inglesa da Austrália, onde os emigrados, em vez de vender sua força de trabalho aos exploradores, desviavamse para a fronteira inexplorada para se tornarem pequenos proprietários. Desse modo, a Lei de Terras, ao impedir a aquisição de terra mediante posse, permitia que os imigrantes adquirissem terras, porém, antes eles teriam de vender sua força de trabalho e acumular o valor necessário para a compra ${ }^{93}$.

A manutenção de um regime de proletarização do trabalho demandava da propriedade agrícola prover a manutenção da força de trabalho durante os doze meses do ano. $\mathrm{O}$ ciclo da produção industrial possibilita a manutenção do nível de emprego por longos períodos, de modo que e a formação de um mercado urbano de trabalho permite ao industrial dispor de mão de obra conforme a sua necessidade, pagando um jornal que corresponde ao tempo trabalhado. Na agricultura, a situação é diferente, pois o ciclo da produção agrícola respeita a um calendário que é próprio de cada cultura ${ }^{94}$. No caso da cafeicultura, durante um semestre inteiro, os trabalhos de carpa dos cafezais e manutenção da propriedade são reduzidíssimos em comparação com o período da colheita. Se a remuneração do trabalho fosse compatível com o tempo de trabalho, demandado ao longo dos meses grande parte dos imigrantes, estaria desempregada na maior parte do ano e a inexistência de outras explorações que absorvesse essa força de trabalho forçaria sua migração para outras áreas, impedindo a consecução da colheita. Na Europa, onde nesse período as zonas rurais estavam densamente povoadas e a terra desconcentrada, as explorações agrícolas podiam contar com a massa de pequenos proprietários e arrendatários que viviam nas redondezas, pagando apenas o jornal ${ }^{95}$.

Os regimes de exploração do trabalho livre adotados no Brasil, principalmente na cafeicultura, realizavam-se por contratos anuais que possibilitavam a fixação dos

\footnotetext{
92 Idem, ibdem.

${ }^{93}$ Cf. MOTTA, 1998, op. cit.; MARTINS, 1981, op. cit.; COSTA, 1982, op. cit.

94 TESSARI, Cláudia Alessandra. Braços para colheita: sazonalidade e permanência do trabalho temporário na agricultura paulista (1890-1915). Campinas: UNICAMP, 2010.

${ }^{95}$ KAUTSKY, 1986, op. cit.
} 
trabalhadores na propriedade durante todo o ciclo agrícola. No entanto, para se fixar os trabalhadores à propriedade, era preciso que ela provesse a sua subsistência ao longo de todo o ano. Desse modo, todos os regimes de exploração experimentados incluíam a concessão de faixas de terra para o cultivo particular das famílias.

Os contratos de parceria, por exemplo, fixavam um determinado número de pés de café que o colono deveria cuidar e colher, além de lhes conceder uma faixa de terra. $\mathrm{O}$ trabalhador recebia uma parte do café colhido e, em muitos casos, o fazendeiro tinha participação nos resultados dos excedentes produzidos na faixa individual. Esse regime de trabalho, ou formas semelhantes, foram adotados na cafeicultura da zona da Mata de Minas Gerais ${ }^{96}$ e no Vale do Paraíba fluminense ${ }^{97}$ depois da abolição. Em São Paulo, entretanto, principalmente no oeste paulista, os contratos de parceria foram comuns apenas no período anterior à abolição. Os imigrantes introduzidos pela política de imigração subvencionada foram empregados em um regime de trabalho que ficou conhecido como colonato ${ }^{98}$. O regime de colonato consistia na contratação anual de famílias de colonos para cuidarem de um determinado número de pés de café e permaneciam fixados nas fazendas à disposição para os trabalhos na colheita. Nesse regime, a remuneração era composta por um conjunto de pagamentos e benefícios que permitiam ao trabalhador permanecer na propriedade durante o ciclo anual, sendo composta pelo pagamento mensal pelo trato do cafezal, calculado pela quantidade de pés de café sob sua responsabilidade; outra remuneração anual calculada pelo volume de café colhido e a concessão de uma porção de terra para uso do colono, o que lhe garantia alimento e lhe permitia extrair um excedente comercializável. Além disso, os colonos realizavam trabalhos esporádicos pelos quais recebiam diárias ${ }^{99}$.

\footnotetext{
${ }^{96} \mathrm{Na}$ Zona da Mata mineira, de acordo com o trabalho de Ana Lanna, o regime de trabalho predominante teria sido também a parceria, embora houvesse outras formas de contrato, algumas das quais incluíam o pagamento em dinheiro.

${ }^{97}$ Segundo Stanley Stein, a capacidade de financiamento dos fazendeiros de Vassouras determinou o regime de trabalho adotado. A safra de 1888 foi colhida por ex-escravos, mediante pagamento em dinheiro; entretanto, nos anos seguintes foram testadas diversas formas de contratação, tais como a empreitada e a parceria, tendo permanecido esta última como a predominante.

98 Colonato não é um termo recorrente na documentação, isto, pelo menos até a década de 1920. Pelo contrário, utilizavam-se recorrentemente os termos trabalho por contrato e assalariamento. Para se referir aos trabalhadores o termo mais recorrente era colono, mas utilizava-se também o termo "operários agrícolas", principalmente em documentos que defendiam a substituição do regime vigente pela “colonização", ou seja, a imigração baseada no assentamento de pequenos proprietários. Campos Salles em sua Mensagem de 1897 (p. 90) dizia: "são os operários agrícolas que acedem às exigências do trabalho na grande propriedade".

${ }^{99}$ HOLLOWAY, 1972, op. cit., pp. 160-3.
} 
O período de maior expansão da cafeicultura brasileira, garantido em sua maior parte pelo avanço da fronteira agrícola no oeste paulista, coincide com o processo de transição do trabalho escravo para o livre encerrado em 1888. No ano da abolição, a safra paulista foi quase o dobro da anterior. Em 1886, havia, segundo Viotti da Costa, 160.665 escravos em São Paulo, nesse ano, o número de imigrantes que até então havia entrado no estado somava 53.517. Em 1896, o estado de São Paulo já havia recebido cerca de 852 mil imigrantes (entre nacionais e europeus). Ignorando-se o número de libertos em 1886, os livres locais e os imigrantes que deixaram São Paulo, pode-se dizer que entre 1886 e 1896 o estado conseguiu multiplicar por cinco vezes o volume da sua força de trabalho.

Todo esse aumento foi conseguido sem recuar um centímetro no regime de concentração fundiária, pois a subvenção estatal havia garantido um fluxo constante de trabalhadores imigrantes, sem que fosse necessário oferecer a posse da terra para incentivá-los, o que por sua vez, traria graves consequências para o sistema de financiamento da lavoura, ao fazer com que as fazendas mantivessem um volume ocioso de força de trabalho ao longo do ano.

O regime de trabalho adotado influenciara diretamente a conformação do sistema de crédito. Por outro lado, a disponibilidade de meios financeiros e mecanismos de crédito adequados limitavam o grau de monetização da remuneração. De acordo com Stanley Stein, a capacidade de financiamento dos fazendeiros de Vassouras teria determinado que os fazendeiros da região adotassem a parceria em vez do pagamento de diárias. Ainda que a safra de 1888 tenha sido colhida por ex-escravos, mediante pagamento em dinheiro, nos anos seguintes, entretanto, foram testadas diversas formas de contratação para driblar a dificuldade de financiamento, tais como a empreitada e a parceria, tendo permanecido esta última como predominante. Por outro lado, a adoção da remuneração monetária mensal ocasionaria, em São Paulo, graves consequências sobre o sistema de financiamento na medida em que aumentava enormemente a demanda pelos adiantamentos concedidos por comissários de café.

\section{Como lembra Delfim Netto:}

A libertação trouxe consigo novos problemas de financiamento, que alteraram as relações entre os comissários e os exportadores. Antes de 1888, os recursos financeiros necessários para custeio da fazenda eram relativamente pequenos, 
pois a parte mais importante desse custeio - que era o pagamento da mão de obra -, praticamente não existia ${ }^{100}$.

Fora por conta dessas novas necessidades monetárias que as firmas comissárias se viram incapazes de financiar seus comitentes, contribuindo para a quebra do seu poder perante as casas exportadoras ${ }^{101}$.

Nos anos finais da monarquia, os preços elevados do café e o grande volume exportado elevaram a receita de divisas que contribuíram para uma rápida elevação do câmbio. A estabilidade cambial $\mathrm{e}$ as novas necessidades financeiras da lavoura fortaleciam as propostas, sempre latentes, a favor do aumento das emissões de moeda. Além desses fatores, vinha sendo disseminada a opinião a respeito da urgência em se aumentar a capilaridade das instituições bancárias para que elas canalizassem de volta ao sistema de crédito o dinheiro gasto com o pagamento de salários, o que poderia ser feito por meio da captação das poupanças dos colonos ${ }^{102}$.

Para justificar o aumento das emissões monetárias, Rui Barbosa argumentava que após a abolição, a necessidade de moeda da economia havia aumentado em 505\% sobre o volume de 212.640:000\$000 em circulação em 1888. Em 1890, o total das emissões realizadas atingiam o valor de 285.943:914\$000 de um total de 506.992:000\$000 ainda por ser concluído ${ }^{103}$. Diazia Rui Barbosa que até aquele momento os fazendeiros obtinham os parcos recursos necessários ao seu financiamento por meio de seus comissários pelo mecanismo de crédito e escrituração, que ordinariamente dispensava a tradição efetiva do dinheiro ${ }^{104}$. Porém, a abolição havia modificado o modo como as fazendas eram financiadas e os proprietários precisavam cada vez mais de moeda para o pagamento de trabalhadores, ainda segundo o Ministro da Fazenda, eles precisavam de dinheiro de contado; porque o jornaleiro, liberto, ou livre, entre nós, desconhece o crédito, e não se acomoda ao trabalho senão atraído e afeiçoado a ele pela pontualidade dos patrões ${ }^{105}$.

Rui Barbosa, evidentemente, havia desconsiderado que os fazendeiros adotavam mecanismos alternativos de financiamento, como o disseminado costume de afiançar as compras de seus empregados no comércio local ou mesmo fornecendo-lhes diretamente

\footnotetext{
100 DELFIM NETTO, 1981, op. cit., p. 23.

${ }^{101}$ Idem, ibdem, p. 24.

102 PELAĖ, Carlos Manuel e SUZIGAN, Wilson. História Monetária do Brasil: Análise da Política, Comportamento e Instituições Monetárias. Brasília: Ed. UnB, 1981, p. 177, SAES, 1986, op. cit.

103 BARBOSA, Ruy. Obras completas de Ruy Barbosa (V. XVIII Tomo II, Relatório do ministro da Fazenda). Rio de Janeiro: Ministério de Educação e Saúde, 1949.

104 Idem, ibdem, p. 142.

105 Idem, ibdem, p. 147.
} 
diversos gêneros, além do pagamento por meio de vales observado em diversas localidades ${ }^{106}$. Nesse sentido, Delfim Netto lembra que era comum aos proprietários tentar reduzir o máximo possível o saldo a liquidar em dinheiro para com seus empregados e na medida em que o fazendeiro conseguisse estabelecer uma conta corrente com seus colonos, o dinheiro funcionava simplesmente como unidade de conta e só era necessário para a liquidação dos saldos, entretanto, isto não significava que o volume de recursos não havia aumentado ${ }^{107}$.

Existem inúmeras estimativas sobre custo de produção, transporte e comercialização de café, no entanto, esses dados, na maioria das vezes, foram confeccionados para subsidiar os projetos de intervenção ou cobrar auxílios à lavoura e devem ser por isso tratados com muita cautela pelo historiador. Ainda assim, vários documentos parecem estabelecer um valor de remuneração pago aos colonos entre $60 \$ 000$ e $100 \$ 000$ por mil pés de café cuidados e a colheita em $\$ 500$ por cada porção de 50 litros de café apanhado, no fim da década de 1890.

Como as despesas eram divididas em cuidado e colheita, sendo a primeira paga por cada mil pés e a segunda por litro de café colhido, uma vez estipulados os valores pagos aos colonos era preciso obter a quantidade de cafeeiros em produção no estado e o volume de café produzido. No entanto, as estatísticas existentes, produzidas pelo mercado cafeeiro, davam conta apenas do volume de café embarcado em Santos e não há informações sobre a quantidade de cafeeiros plantados até 1909. Uma estimativa de 1909 afirma que havia no estado de São Paulo cerca de 17 milhões de pés de café, considerando-se o valor mínimo apontado por Holloway para a remuneração dos colonos em torno de $60 \$ 000$ anuais ${ }^{108}$, podemos fazer uma estimativa aproximada a respeito dos valores aplicados anualmente no custeio da lavoura cafeeira por volta de 1.420.000:000\$000. Esse valor é extremamente elevado se considerarmos que o volume de moeda em circulação era de 753.736:000\$000 ${ }^{109}$ e que os depósitos bancários eram da ordem de 170.957:114\$000 ${ }^{110}$.

106 Cf. MISSURA, Fábio Augusto, Costa machado: ação política e empresarial na sociedade do café em rio pardo (1877-1917), Franca: UNESP-FHDSS (Mestrado em História), 2003.

${ }^{107}$ DELFIM NETTO, 1981, op. cit., p. 23.

${ }^{108}$ HOLLOWAY

${ }^{109}$ PIRES DO RIO, José, A moeda brasileira e seu perene carater fiduciario. Rio de Janeiro: Jose Olympio, s/d, p. 175.

${ }^{110}$ SAES, 1986, op. cit., p. 219. 
Na medida em que o crédito bancário fosse expandido e aumentasse o volume de depósitos, o mecanismo multiplicador de meios de pagamento contribuiria para melhorar a circulação e a obtenção de recursos pelos fazendeiros, fosse diretamente por meio do empréstimo bancário ou pelos tradicionais intermediários, entretanto, uma expansão mais significativa do crédito bancário ocorreria apenas no fim da década de $1920^{111}$.

\subsection{Novos mecanismos: reforma da lei de hipotecas, o penhor e o warrant}

A decadência do regime escravista foi acompanhada por uma evolução significativa nos mecanismos empregados no financiamento, principalmente, no que diz respeito às garantias fornecidas pelos fazendeiros. No início da década de 1880, a expectativa do fim da escravidão afligia os proprietários rurais do Vale do Paraíba, de acordo com Stanley Stein, a rápida depreciação do braço escravo cobria as fazendas com sua mortalha, anos antes da abolição ${ }^{112}$. A aprovação da Lei do Sexagenário foi recebida como um golpe fatal para muitos fazendeiros de zonas escravistas, como era o caso de Vassouras, estudada por este autor. Além dos fazendeiros, a abolição assombrava especialmente os seus credores e, em 1885, o discurso de um deputado na Câmara resumia a preocupação desse segmento ao afirmar que a verdadeira garantia dos empréstimos não estava nos imóveis, mas no valor dos escravos: quanto maior é o numero destes em um estabelecimento rural, tanto maior é a garantia do credor, o mesmo deputado denunciava a atitude de alguns fazendeiros que para evitar ações de execução ameaçavam libertar seus escravos ${ }^{113}$.

Em 1883, uma estatística sobre as hipotecas adquiridas por três bancos hipotecários (Banco do Brasil, Predial e Crédito Real de São Paulo) apontava a existência de 30.358 escravos hipotecados na zona tributária ao porto do Rio de Janeiro e mais 9.908 na região do Porto de Santos. Esses escravos representavam 48\% do valor das propriedades hipotecadas na província do Rio de Janeiro, 44\% das do Vale do Paraíba paulista e $38 \%$ no oeste paulista ${ }^{114}$. Tais dados explicam os motivos que levaram o Banco do Brasil a encerrar a sua Carteira Hipotecária e recuo dos demais bancos nessa seara ${ }^{115}$,

${ }^{111}$ Idem, ibdem, p. 196.

${ }^{112}$ STEIN, 1961, op. cit., p. 294.

${ }^{113}$ Correio Paulistano, 9 de junho de 1883, p. 1."Camara dos Deputados".

${ }^{114}$ LAERNE, C. F. Van Delden. Le Brésil et Java, rapport sur la culture du café en Amérique, Asie et Afrique. La Haye: Martinus Nijhoff, 1885, pp. 190-5.

${ }^{115}$ MARCONDES, 2002, op. cit., nota 18. 
encerrando-se o ciclo de tentativas do governo imperial de estabelecer um sistema de financiamento bancário da agricultura, que se iniciara em 1864 com a aprovação da lei hipotecária e a substituição da carteira de emissões do Banco do Brasil pela Carteira Hipotecária.

Ao mesmo tempo, os credores da lavoura, que não se restringiam às carteiras hipotecárias desses três bancos, mas incluíam uma camada de capitalistas e comissários, reivindicavam modificações na legislação hipotecária de modo a adequá-la à nova realidade. De acordo com a legislação vigente, o imóvel não podia ser leiloado por valor inferior ao da avaliação judicial e caso não se apresentasse um lance superior, o credor era obrigado a assumir a propriedade do imóvel, dando quitação à dívida - a chamada adjudicação forçada. Os credores resistiam em assumir a propriedade dessas fazendas depreciadas pela idade avançada dos cafezais e cujo valor estava ameaçado pela perspectiva da abolição, os riscos eram ainda maiores quando se considerarmos a conjuntura de queda dos preços do café no mercado internacional.

Os credores que, caso a propriedade transferida fosse avaliada por valor superior ao da dívida, eles poderiam ser obrigados a ressarcir a diferença ao devedor. Assim dizia um deputado em sessão da Câmara Federal: quem empresta dinheiro quer receber em paga dinheiro, e não bens avaliados tão alto que lhe causam os maiores prejuízos, além de que às vezes ainda é o credor obrigado a dar mais dinheiro para cobrir o preço da adjudicação ${ }^{116}$. Apesar do grande alarido que se fez a respeito de terem os credores de ressarcir seus devedores, aparentemente, esta não parece ter sido uma situação comum. O autor do Retrospecto Comercial de 1884 deixara escapar que esta era, por enquanto, mais um receio do que uma constatação real: pode o devedor remisso, sob a proteção da lei hipotecária, entregar à sociedade os seus bens, exigindo dela em dinheiro a metade do valor total. E não se figura aqui uma simples hipótese ${ }^{117}$, mais à frente, o Retrospecto sugere que os credores preferiam negociar com os devedores uma alternativa às execuções: muitos credores hipotecários não iniciam o processo de execução com receio de receberem, em vez do dinheiro adiantado, bens de que não se cogitara no contrato e a que não saberão dar aplicação ${ }^{118}$.

\footnotetext{
${ }^{116}$ Correio Paulistano, 9 de junho de 1883, p. 1."Camara dos Deputados".

117 JORNAL DO COMMERCIO, Retrospecto Commercial do Jornal do Commercio, 1884. Rio de Janeiro. Typ. do Jornal do Commercio, 1885, p. 4.

${ }^{118}$ Idem, ibdem.
} 
Analisando os trabalhos que abordaram a questão do crédito, mesmo nas análises feitas por contemporâneos, percebemos que o problema da execução aparece recorrentemente nos debates sobre a legislação hipotecária. Em 1848, por exemplo, Souza Franco afirmava que a legislação vigente não dava ao credor segurança quanto à execução da hipoteca ${ }^{119}$. Entretanto, é preciso ponderar que as críticas feitas contra o processo de execução naquele período diziam respeito à falta de publicidade sobre os ônus que pesavam sobre os imóveis e a insegurança quanto aos títulos de propriedade. Problemas que, aparentemente, foram resolvidos com a reforma de 1864, visto que estes não aparecem nos debates sobre a lei hipotecária na década de 1880. As críticas que ressurgem nesse momento contra o processo de execução estavam relacionadas ao próprio processo de decadência da cafeicultura escravista, na medida em que muitas propriedades encontravam-se depreciadas tanto pela ação do tempo como pela ameaça da abolição.

O Clube da Lavoura e do Comércio do Rio de Janeiro, órgão que representava o interesse dos credores da lavoura cafeeira, reivindicava a aprovação de uma lei que instituísse a "falência civil", ou seja, a possibilidade de impor nas execuções hipotecárias (regida no âmbito da legislação cível) sanções às quais estavam sujeitos os comerciantes insolventes, por conta do Código Comercial. Também eram reivindicadas alterações na legislação hipotecária de modo a permitir o penhor de bens móveis, tais como implementos e os frutos pendentes, independentemente da propriedade já se encontrar onerada por hipoteca. Desse modo, era permitido ao comissário, capitalista ou banco, emprestar sob garantia do café a ser colhido e, em caso de inadimplência, o credor hipotecário poderia executar a propriedade sem que o credor pignoratício fosse molestado ou vice-versa ${ }^{120}$.

A pressão dos credores surtiu efeito e, logo após a aprovação da Lei do Sexagenário, foi aprovado o Decreto n 3.272 , de 5 de outubro de 1885 , chamado pelos contemporâneos de "Lei das execuções civis e comerciais" ${ }^{121}$. Essa lei alterava o processo das execuções, tanto as cíveis como as comerciais e ainda reformava a legislação hipotecária. No que dizia respeito às execuções, foi definido que o juízo comercial passaria a cuidar também das execuções hipotecárias que até então corriam na justiça

\footnotetext{
${ }^{119} \mathrm{Cf}$. FRANCO, 1984, op. cit.

${ }^{120}$ FERREIRA, 1977, op. cit., pp. 71-79.

${ }^{121}$ Cf. FERREIRA, 1977, op. cit.; CARONE, Edgard. A República velha, São Paulo: Difel, 1972, v.2 (Instituições e classes sociais).
} 
civil. Já no que dizia respeito à lei hipotecária foi extinta a adjudicação forçada e criado o penhor sobre os frutos pendentes e instrumentos da lavoura ${ }^{122}$.

Separavam-se assim os bens móveis do imóvel para que pudessem servir de garantia a empréstimos distintos e simultâneos, o crédito de curto e médio prazo para custeio da safra e o crédito de longo prazo para realização de melhorias e expansão do cultivo $^{123}$. O surgimento do penhor agrícola em 1885 refletia a importância que o custeio anual da lavoura adquiria sob o contexto do trabalho livre, exigindo maior volume de adiantamento e menor comprometimento de longo prazo devido ao fim das imobilizações para compra de escravos. Seu surgimento é reflexo direto da transição do trabalho escravo para o livre que transformara o modo pelo qual se financiavam as propriedades.

Em 1886, um grupo de capitalistas de São Paulo criava o Banco da Lavoura e seus anúncios coletados em um jornal paulista por Flávio Seas sugeriam a relação do penhor com a transformação no regime de trabalho:

A lavoura neste período difícil de transformação do trabalho encontrará no penhor agrícola de colheitas produtos armazenados, animais, máquinas e acessórios, novos meios de crédito. Ao comércio abre-se nova ordem de operações, tão seguras quanto lucrativas. Trata-se de instituição de grande interesse prático, quer do ponto de vista agrícola, quer do comercial ${ }^{124}$.

Dada a natureza dos créditos fornecidos pelos comissários de café, é provável que essa nova modalidade de garantia fosse muito adequada a esse agente tão importante para o financiamento da cafeicultura. Recentemente, Rodrigo Fontanari pesquisou o financiamento da cafeicultura no município de Casa Branca, no oeste paulista, entre os anos de 1874 e 1914. Ele analisou contratos de empréstimos realizados com garantia de hipotecas e penhor, e os dados colhidos indicam uma diferenciação entre os credores hipotecários e pignoratícios que corroboram com tal afirmação. A tabela abaixo demonstra a distribuição dos empréstimos sobre penhor e hipoteca de acordo com a ocupação dos credores.

${ }^{122}$ OLIVEIRA, A. de Almeida, A Lei das execuções ou Consolidação e concordância das disposições, que, segundo a Lei n. 3272 de 5 de outubro de 1885 e o regulamento n. 9549 de 23 de janeiro de 1886, regem as acçoes hypothecarias e de penhor agrícola e as execuções commerciaes e civis em geral, Rio de Janeiro: Garnier, 1987.

${ }^{123}$ Cf. ALBUQUERQUE, Diogo Velho C. de, Regimen Hypothecario, 1918; GAMA, A. Dionysio. Penhor civil, Mercantil e Agricola. Sao Paulo: Saraiva, 1919 e OURO PRETO, Affonso Celso de Assis Figueiredo, Visconde de. Credito Movel pelo penhor e o bilhete de mercadorias, Rio de Janeiro: Laemmert, 1898, p. 337.

${ }^{124}$ SAES, 1986, Crédito e bancos..., pp. 71-2. 
Tabela 1: Créditos concedidos entre 1896 e 1814 em Casa Branca, por ocupação dos credores (contos de réis)

\begin{tabular}{lrrrr}
\hline & Credores hipotecários & \multicolumn{2}{c}{ Credores pignoratícios } \\
\hline Negociante/comerciante & $1.082: 590$ & $5 \%$ & $525: 510$ & $5 \%$ \\
\hline Capitalista & $3.090: 730$ & $13 \%$ & $70: 500$ & $1 \%$ \\
\hline Proprietário & $2.167: 150$ & $9 \%$ & $382: 000$ & $4 \%$ \\
\hline Comissário & $4.398: 660$ & $19 \%$ & $6.532: 840$ & $63 \%$ \\
\hline Lavrador & $5.835: 410$ & $25 \%$ & $894: 140$ & $9 \%$ \\
Banco Nacional & $3.014: 890$ & $13 \%$ & $694: 810$ & $7 \%$ \\
Banco internacional & $1.621: 730$ & $7 \%$ & $821: 730$ & $8 \%$ \\
\hline Outros & $2.218: 230$ & $9 \%$ & $201: 120$ & $2 \%$ \\
\hline Indeterminado & $54: 100$ & $0 \%$ & $186: 950$ & $2 \%$ \\
\hline Total & $23.483: 490$ & & $10.309: 600$ & $100 \%$ \\
\hline Fonte: Tabela montada com base nos dados contidos em FONTANARI, 2010, op. cit., p. 84. \\
\hline
\end{tabular}

Com relação às hipotecas, é possível observar uma distribuição mais homogênea da ocupação declarada pelos credores, havendo uma maior participação de lavradores 25\% (empréstimos concedidos entre fazendeiros), seguida por comissários, 19\%, enquanto os bancos nacionais e estrangeiros somaram $20 \%$ e os capitalistas, $13 \%$. Já no que diz respeito aos créditos sobre penhor há um claro predomínio do comissariado que respondeu $63 \%$ das operações. Esses dados demonstram a relação entre a garantia móvel e o crédito fornecido por comissários.

Uma reforma da legislação hipotecária de 1864 foi concretizada nos primeiros anos da República e concebida como parte da reforma financeira realizada pelo ministro Rui Barbosa. A reforma compunha-se de uma lei autorizando a organização dos bancos de emissão, reforma da legislação de sociedades anônimas, reforma da legislação hipotecária (Decreto 169-A, de 19 de janeiro de 1890), além da organização do crédito móvel - bilhetes garantidos pelo penhor agrícola (Decreto 165-A, de 17 de janeiro de 1890). Os decretos referentes a hipotecas e o crédito móvel foram regulamentados em maio de $1890^{125}$. No que diz respeito à execução hipotecária, a nova lei mantinha as modificações impostas pelo decreto de 1885 , como eliminação da adjudicação forçada e a tramitação do processo no juízo comercial.

Em 1903, surgia um novo mecanismo de garantia para os empréstimos agrícolas, cuja discussão se arrastava desde 1896 e suscitara muita polêmica; trata-se do warrant,

${ }^{125}$ Decreto n. 370, de 2 de maio de 1890. "Manda observar o regulamento para execução do decreto n. 169 A de 19 de janeiro de 1890, que substituiu as leis n. 1237 de 24 de setembro de 1864 e n. 3272 de 5 de outubro de 1885, e do decreto n. 165 A de 17 de janeiro de 1890, sobre operações de credito móvel”. 
um título de crédito emitido sobre mercadorias depositadas em armazéns gerais, docas e trapiches ${ }^{126}$. O warrant surgira com a proposta de reforçar a chamada "organização comercial do café", esta última, entendida como a necessidade de se consolidar financeiramente a rede de intermediários nacionais diante das casas exportadoras estrangeiras. O estabelecimento de companhias de armazéns gerais junto ao Porto de Santos e nos entroncamentos das estradas de ferro deveria permitir maior controle sobre o escoamento da safra, possibilitando a regularização do fluxo de mercadorias, contribuindo para segurar a cotação do café. Porém, muitos comissários temiam que o warrant permitisse aos fazendeiros negociar e obter empréstimos sem a sua intermediação.

Os negócios com warrant funcionavam da seguinte forma: ao remeter o café aos armazéns, o depositante recebia um conhecimento de depósito e também o título opcional chamado warrant. $\mathrm{O}$ conhecimento era um título que comprovava a propriedade sobre o café depositado e era transmissível por endosso. Desse modo, era possível realizar diversas transações sem que o café saísse do armazém. Já o título de warrant permitiria ao depositante penhorar a mercadoria depositada.

Seu funcionamento dava-se da seguinte forma: um fazendeiro ou negociante depositava o café no armazém e recebia o comprovante de depósito. Opcionalmente ele recebia o warrant e com esse título dirigia-se a um capitalista ou banco onde obtinha um empréstimo, entregando o warrant como garantia. Por sua vez, o credor escrevia no verso do comprovante de depósito que o saque da mercadoria estava atrelado à liquidação do crédito, indicando-se o prazo e a taxa de juros. Tanto o comprovante de depósito como o warrant podiam ser transferidos mediante endosso. Para reaver a mercadoria, o portador do comprovante deveria apresentar ao armazém o warrant quitado ao seu portador. Em caso de não haver quitação do crédito, o portador do warrant protestava o título e o café depositado era levado à leilão ${ }^{127}$.

\footnotetext{
${ }^{126}$ Decreto $\mathrm{n}^{\mathrm{o}} 1.102$, de 21 de novembro de 1903 - "Institui regras para o estabelecimento de empresas de armazens gerais, determinando os direitos e obrigações dessas empresas".

${ }^{127}$ Cf. VIDAL, Raphael A. Sampaio, Organização Commercial da Defesa do Café - Armazéns Gerais e seus títulos (Warrant, etc.): Lei vigente e comentário, São Paulo: Duprat, 1906 e SOARES, José J., Sociedades Cooperativas e o regime democrático, teoria e prática das instituições mutualistas acomodadas a legislação atual, Rio de Janeiro: s/n., 1955.
} 


\subsection{Muito além do comissário: um crédito multifacetado e hierarquizado}

Em São Paulo, o comércio cafeeiro apresentava-se menos concentrado que no Rio de Janeiro durante o auge da produção vale-paraibana. Além disso, a cadeia de intermediários era mais complexa e incluía desde agentes que repassavam o café a casas maiores até o estabelecimento de firmas comissárias menores, com sede no interior, que concorriam com aquelas sediadas em São Paulo e Santos, além de uma ampla gama de comerciantes não especializados que tinham na compra e venda de café apenas uma parte de seus negócios. E ainda havia a penetração de casas exportadoras no interior onde compravam o café diretamente aos fazendeiros e negociantes locais, dispensando a intermediação das casas comissárias.

No entanto, se o comércio comissário santista estava menos concentrado e talvez menos entrelaçado ao crédito bancário como o comissariado fluminense, isto não significa que a sua participação no financiamento da lavoura fosse reduzida. Em 1912, quando firmas estrangeiras lançaram uma ofensiva por meio de boletins onde prometiam aos fazendeiros melhores preços e fornecimento de crédito que os libertariam dos intermediários, a Associação Comercial de Santos defendeu a atuação do comércio comissário do seguinte modo:

A organização do comércio comissário de Santos é perfeitamente conhecida dos próprios lavradores, que sabem que, devido a ela, é que os comissários podem fazer a colossal movimentação de capital, a ponto de, dadas certas circunstâncias, chegarem a ter soma nunca inferior a duzentos mil contos de réis, em mão de seus fregueses, sujeitando-se aos riscos inerentes. A organização do comércio de comissões em Santos é uma coisa conhecida; e toda a gente sabe que é daqui que tem partido o único auxílio que a lavoura de São Paulo tem tido; de Santos foi para o interior a enorme soma de capital com que o lavrador paulista conseguiu formar os 700 milhões de pés de café, que constituem a riqueza do estado de S. Paulo. Santos sempre foi o mercado monetário do grande Estado de S. Paulo; e, graças à constituição de seu comércio de comissões, nenhum lavrador, medianamente orientado e em condições de solvabilidade, deixou de encontrar aqui os recursos indispensáveis ao seu custeio ${ }^{128}$.

De acordo com Marieta de Moraes Ferreira, as casas comissárias do Rio de Janeiro sustentavam sua posição de predomínio graças ao relacionamento que mantinham com o capital bancário. Esse vínculo fora abalado durante a crise da cafeicultura escravista, ocasionando a reorganização do comércio cafeeiro, que se tornou mais competitivo, além de diminuir o grau de especialização das firmas envolvidas. Essas

128 PEREIRA, Maria Apparecida Franco, Comissário de café no porto de Santos: 1870-1920. São Paulo, 1980. 
características apontadas pela autora como consequência da crise da cafeicultura fluminense apresentam, entretanto, muita semelhança com a descrição da atuação dos comissários em Santos durante o auge de sua atuação entre o final do século XIX e início do século $\mathrm{XX}^{129}$.

Além do vínculo estreito entre as firmas comissárias e as casas bancárias do Rio de Janeiro, a mudança no regime de trabalho também impôs novas características ao introduzir novas demandas financeiras.

Uma característica que distingue o comissariado paulista do fluminense é o fato de que as firmas comissárias do Rio de Janeiro tinham sua origem na importante elite mercantil daquela praça, algo que não ocorrera em São Paulo. Em Santos, não havia um poderoso grupo mercantil que sustentasse o controle dos canais de comercialização tal como fizeram as firmas comissárias do Rio de Janeiro. De acordo com a descrição de Maria Apparecida Franco Pereira, os comerciantes oriundos do comércio de importação e exportação, casas tradicionais que haviam iniciado seus negócios com o comércio de açúcar e que passaram a comercializar café na década de 1850 , perderam sua posição no comércio cafeeiro na década de 1870 . Visto que as grandes firmas comissárias que surgiram nas últimas décadas do século eram organizadas na forma de sociedades que agrupavam importantes fazendeiros de café ${ }^{130}$. Além disso, como bem observou Flávio Saes, ao contrário do Rio de Janeiro, que concentrava as atividades portuárias e era a principal praça comercial do país, Santos seria deslocada para um papel secundário no contexto provincial, dada a concentração das atividades financeiras e de abastecimento do complexo cafeeiro na cidade de São Paulo - principalmente depois da década de 1870 . Além disso, no contexto imperial, Santos se mantinha financeiramente dependente em relação à praça fluminense, visto que os descontos de títulos cambiais continuariam a ser realizados por bancos do Rio de Janeiro até a década de $1890^{131}$.

Por último, é preciso lembrar que entre 1880 e 1890 o comércio internacional de café passou por intensas transformações determinadas pela verticalização oligopolista observada, sobretudo, nos EUA, onde um cartel de importadores liderados pela indústria torrefadora assumia um crescente controle sobre o comércio mundial do produto,

\footnotetext{
${ }^{129}$ Idem, ibdem.

${ }^{130}$ Idem, ibdem, p. 126.

${ }^{131} C f$. SAES, F. A. M. de. A grande empresa de serviços públicos na economia cafeeira 1850-1930. São Paulo: Hucitec, 1986.
} 
suprimindo a força das casas inglesas e exercendo forte pressão sobre os mercados exportadores, o que incluiria, no caso do Brasil, a entrada dessas firmas na concorrência com as casas comissárias pelo café remetido do interior.

Diversos autores descreveram as escaladas de conflitos entre o comércio comissário e as casas exportadoras, apontando o crescimento da escala de produção, o aumento da demanda financeira para custeio, a queda dos preços e a retração monetária do final do século XIX como responsáveis pelas transformações ocorridas no comércio cafeeiro que causariam o enfraquecimento dos comissários diante das casas exportadoras. Em 1896, essas firmas começaram a comprar o café diretamente no interior, prática combatida como muita veemência pelos comissários ${ }^{132}$. Além disso, várias pesquisas demonstraram que as casas exportadoras também realizavam adiantamentos a fazendeiros, como foi o caso da Theodor Wille ${ }^{133}$, Neumann, Geep \& $\mathrm{Co}^{134}$ e a Brazilian Warrant Company ${ }^{135}$.

A análise em conjunto de diversas obras que trataram de aspectos isolados do comércio e do financiamento da cafeicultura paulista nos permite verificar a grande diversificação dos agentes envolvidos na comercialização e no financiamento do café, o que nos permite extrapolar a tradicional descrição do comissário de café como o banqueiro do fazendeiro. Três dissertações, em especial, permitem uma compreensão mais ampla desse assunto, trata-se dos trabalhos de Maria Apparecida de Moraes Pereira O comissário de café no Porto de Santos (1870 - 1920), dissertação defendida em 1980, o trabalho de Rodrigo da Silva Teodoro O Crédito no Mundo dos Senhores do Café: Franca 1885-1914, dissertação defendida em 2006, e a dissertação de Rodrigo Fontanari O Problema do Financiamento: Uma Análise Histórica Sobre o Crédito no Complexo Cafeeiro Paulista. Casa Branca (1874-1914), defendida em $2011^{136}$.

De acordo com Franco Pereira, os negociantes de café estavam disseminados pela 'hinterland' paulista desde o fim do século XIX. Havendo, por exemplo, a participação de compradores que, nas mais diversas localidades adquiriam café por conta própria para

\footnotetext{
${ }^{132}$ Cf. DELFIM NETTO, 1959, op. cit.; TAUNAY, op. cit., v. 10; SAES, F. A. M. de. Crédito e bancos no desenvolvimento da economia paulista 1850 - 1930. São Paulo: IPE/USP, 1986; CARONE, 1972, op. cit. ${ }^{133} C f$ : MORAES, Maria Luiza Paiva Melo. Atuação da firma Theodor Wille \& Cia. no mercado cafeeiro do Brasil, 1844-1918. São Paulo: FFLCH, 1988 (Tese de Doutorado).

${ }^{134}$ FONTANARI, 2001, op. cit., p. 110.

135 PEREIRA, 1980, op. cit., p. 108-9.

${ }^{136}$ PEREIRA, 1980, op. cit.; TEODORO, R. S. O Crédito no Mundo dos Senhores do Café: Franca $1885-$ 1914. Campinas (Dissertação de Mestrado), 2006; FONTANARI, 2010, op. cit.
} 
revender em Santos. Outros tinham armazém de artigos gerais (as 'vendas') e recebiam café para negociar em outras praças. Havia ainda os "agentes" de casas comissárias, que nas localidades podiam exercer outras atividades, como a de fazendeiro, comerciante e capitalista, e que remetiam o café de terceiros para seus correspondentes em São Paulo ou Santos. Figura muito peculiar nesse contexto paulista era o "maquinista", proprietário de máquina de beneficiar café, que nas localidades do interior comprava ou tomava café em consignação de pequenos fazendeiros para beneficiá-lo e remeter a Santos ${ }^{137}$. Por último, além das grandes firmas comissárias de Santos, havia outras na capital paulista e pequenas firmas "independentes" espalhadas por diversas cidades do interior e que atendiam, principalmente, os pequenos lavradores ${ }^{138}$.

Uma pesquisa que contribuiu para compreensão do modo como era realizado o financiamento no complexo cafeeiro é o trabalho de Rodrigo Fontanari que analisou contratos de penhor e hipotecas registrados em Casa Branca. Para esse pesquisador a concessão de crédito apresentava-se como uma atividade multifacetada, havendo uma variada gama de agentes e de modalidades de financiamento, cuja distribuição refletia a hierarquização do complexo cafeeiro. Essa ampla gama de agentes encarregados do financiamento corresponde à grande variedade de agentes encarregados da comercialização do café observada por Pereira.

Fontanari também demonstrou a hierarquização no acesso ao crédito. O crédito bancário que podia ser concedido em condições mais vantajosas de prazo e juros estava disponível, sobretudo, aos maiores fazendeiros da região. Esses fazendeiros mantinham, aliás, relações diretas com grandes casas comissárias e firmas exportadoras com as quais também costumavam obter contratos de financiamento mediante penhor e hipoteca. Enquanto isso, aos fazendeiros menores, estavam disponíveis os empréstimos concedidos por capitalistas e negociantes locais, por meio de contratos que se mostravam mais onerosos. Geralmente, esses capitalistas eram os mesmos fazendeiros que obtinham acesso direto ao crédito bancário ${ }^{139}$.

No período entre 1896 e 1906, a queda dos preços do café causou severa restrição do crédito que, por sua vez, era agravada pela política monetária restritiva adotada no governo de Campos Salles. Porém, mesmo durante a conjuntura desfavorável, a produção

\footnotetext{
${ }^{137}$ PEREIRA, 1980, op. cit., p. 89-92.

${ }^{138}$ Idem, ibdem., 144

${ }^{139}$ PEREIRA, 1980, op. cit.; TEODORO; 2006, op. cit.; FONTANARI, 2010, op. cit.
} 
paulista não deixou de aumentar, e diversas regiões encontravam-se em plena expansão, como era o caso do município de Franca, que para nós é um exemplo emblemático de como a cafeicultura foi capaz de se manter em expansão mesmo nas quadras mais difíceis de baixa de preços e retração do crédito. Mas como os fazendeiros de localidades como Franca lograram manter a produção e ainda expandir suas plantações? Este questionamento foi colocado por Rodrigo da Silva Teodoro e também por Rogério Naques Faleiros que estudaram a dinâmica do crédito e os contratos de trabalho e naquela localidade.

Faleiros observou que os fazendeiros haviam adotado um expediente, aparentemente muito peculiar para reduzir os seus custos durante a crise, ao entregar seus cafezais em parceria aos colonos, repartindo com os trabalhadores os custos e os riscos advindos das oscilações do mercado. Além disso, o autor também demonstrou como que os contratos de formação do cafezal, modelo vigente nas zonas de expansão da cafeicultura, possibilitavam aos fazendeiros ampliar as plantações com pouco dispêndio monetário, mediante a permissão para que empreiteiros e colonos plantassem entre as covas dos cafeeiros enquanto aguardavam pela maturação da plantação ${ }^{140}$.

Rodrigo Teodoro, ao analisar os créditos escriturados em cartórios de Franca, verificou que em decorrência da expansão monetária da década de 1890 houve um aumento no volume do crédito concedido. Porém, a crise ocasionou um recuo geral dos empréstimos naquela localidade. Posteriormente, Teodoro observou que indivíduos classificados como capitalistas adquiriram papel relevante na concessão de empréstimos, ocupando o lugar dos comissários no financiamento do café ${ }^{141}$. Ao observar contratos escriturados naquela localidade, ele observou grande número de capitalistas intermediando o envio de café para casas comissárias de São Paulo e Santos e, a partir da análise desses contratos, ele sugeriu que ao fim da crise, os capitalistas locais passaram a atuar de forma coordenada com as casas comissárias de Santos, repassando aos fazendeiros o crédito obtido pelos comissários aos bancos da capital e de Santos, dividindo os riscos da avaliação de crédito.

${ }^{140}$ FALEIROS, Rogério N. Homens do café: Franca 1880-1920. Ribeirão Preto: Holoes, 2002.

141 TEODORO, 2006, op. cit., pp. 147-158. 
Figura 1: Modelo de sistema de financiamento da cafeicultura em São Paulo

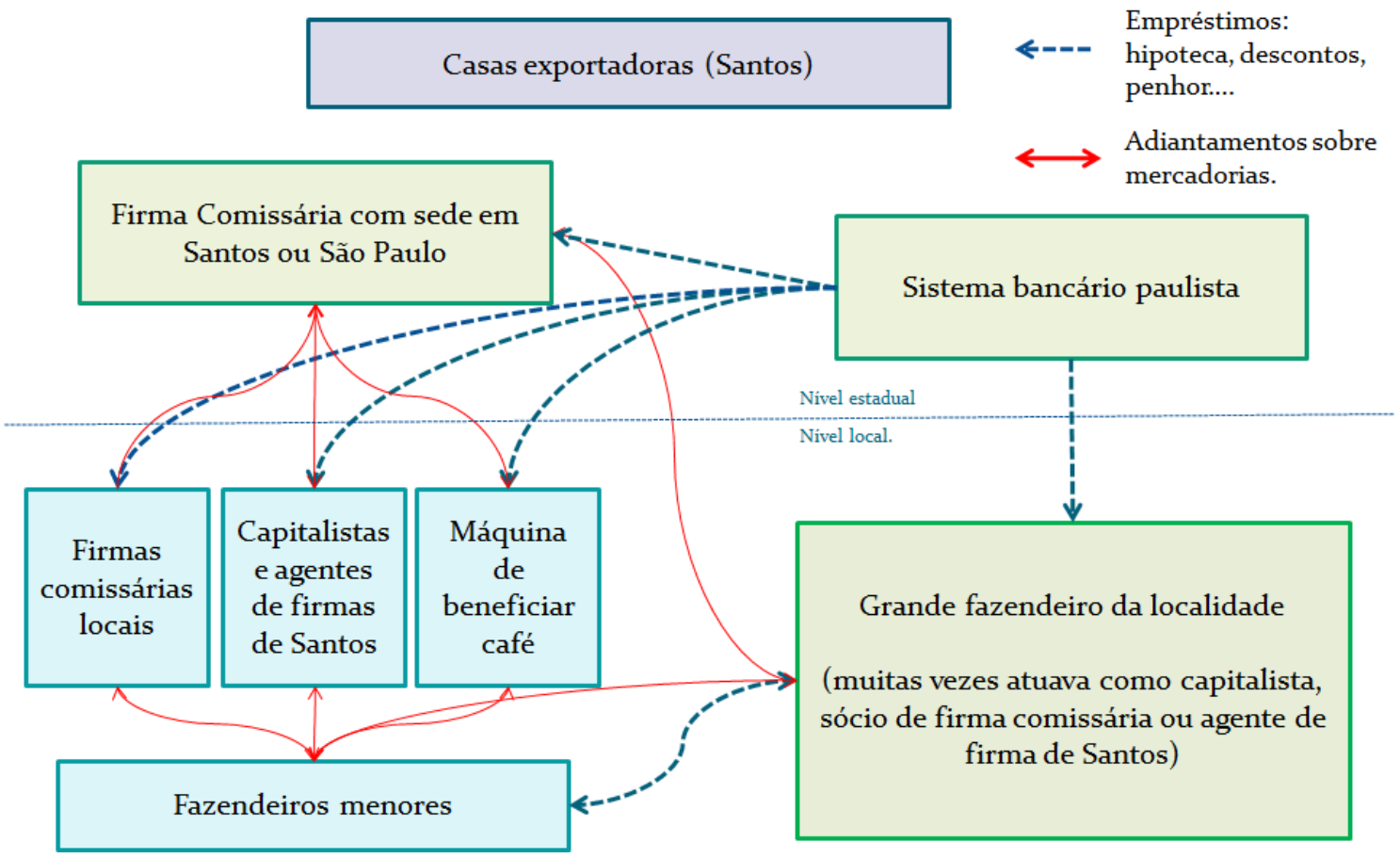

Desse modo, o capitalista cumpriria uma função primordial no complexo agroexportador atuando como uma correia de transmissão dos financiamentos do comissariado de acordo com o esquema bancos - casa comissária - capitalista local fazendeiro $^{142}$.

Desse modo, buscamos reconstruir através da análise da historiografia, que abordou a cafeicultura no modo como estava organizado o sistema de financiamento no complexo cafeeiro escravista e a forma como esse sistema evoluiu após a transição para o trabalho livre e o desenvolvimento do complexo cafeeiro paulista e que resultaram nas reformas da legislação hipotecária (1885 e 1890) que alteraram o processo das execuções hipotecárias e criaram o penhor agrícola, uma nova forma de garantia mais adequada às novas necessidades do custeio anual das fazendas.

Por outro lado, no que diz respeito à atuação dos comissários de café em São Paulo, embora estivessem tradicionalmente envolvidos no financiamento da cafeicultura, não exerciam o mesmo predomínio nas relações de crédito como foi observado para o complexo articulado em torno do Rio de Janeiro, principalmente porque entre as firmas

${ }^{142}$ Idem, p. 112. 
comissárias de Santos e os fazendeiros do "oeste" paulista havia uma miríade de intermediários que se inseriam na negociação das safras e também no financiamento da produção. No que diz respeito ao capitalista, observa-se que eles mantiveram atribuições semelhantes àquelas relatadas para o complexo escravista, porém, em muitos casos, observa-se a prática desses agentes negociando o café e financiando os fazendeiros de forma articulada com os comerciantes de Santos. Em relação ao sistema bancário não houve alteração significativa e mesmo que não se observasse um vínculo tão estreito entre banco e casa comissária como fora observado no Rio de Janeiro antes da abolição, os bancos comerciais paulistas eram bancos de depósito e descontos e contribuíam para o financiamento agrícola na medida em que estimulavam a circulação das letras de câmbio que davam liquidez aos negócios, sobretudo, o custeio da safra. 


\section{CRISE ECONÔMICA E CRISE POLÍTICA: A DINÂMICA DOS CONFLITOS NO INTERIOR DO COMPLEXO CAFEEIRO}

Neste segundo capítulo abordaremos os efeitos da crise cafeeira de 1896-1906 sobre a esfera política do complexo cafeeiro paulista e sua implicação na política de crédito agrícola adotada pelo governo paulista em 1906. Como se trata de um período de intensa expansão do cultivo de café, é preciso discutir a que tipo de crise estamos nos referindo. Não se trata, evidentemente, de uma crise geral da produção cafeeira tal como a que se abatera sobre o Vale do Paraíba a partir da década de 1870, tão pouco estamos tratando de uma interrupção do movimento de expansão da cafeicultura paulista, pelo contrário, esse era um momento de expansão da fronteira agrícola que no fim do século XIX já ultrapassava as fronteiras do estado, atingindo o norte do Paraná e o sul de Minas Gerais. Expansão que os poderes públicos do estado de São Paulo buscaram interromper em 1902 com a criação de um imposto proibitivo sobre as novas plantações de café.

A queda dos preços era reflexo do aumento das exportações e Delfim Netto demonstrou a existência de um movimento cíclico dos preços do café que estimulavam e freavam a expansão das plantações desde meados da década de 1850. Esse autor diagnosticou três ciclos de expansão e retração entre 1857 e 1906, e em cada um deles observa-se uma tendência de elevação que estimulava o aumento das plantações até que a saturação dos mercados consumidores ocasionasse um período de redução dos preços, desestimulando novas plantações. Ao fim de cada ciclo, um período relativamente longo de preços baixos permitia a conquista de novos mercados consumidores, aumentando assim a demanda e dando início a uma nova fase de elevação. A cada nova fase de expansão ocorriam mudanças na estrutura produtiva e, assim, o primeiro ciclo de preços fora marcado pela expansão da cafeicultura no Vale do Paraíba; a fase ascendente do segundo ciclo marcaria o início da produção cafeeira na zona de Campinas, no estado de São Paulo.

A lenta fase de deflação do segundo ciclo de preços ocorrida entre 1873 e 1885 relacionava-se à decadência da produção no Vale do Paraíba e a desagregação do próprio regime escravista; entretanto, foi também nessa fase que se observou a expansão das estradas de ferro paulistas, a intensificação da imigração e o início do intenso movimento de expansão das plantações de café no oeste paulista. Quando em 1886 teve início um novo ciclo de preços, a zona tributária do Porto de Santos já havia suplantado o Rio de Janeiro como principal produtora de café do Brasil e a cafeicultura paulista havia 
assegurado um fluxo de trabalhadores imigrantes que lhe permitiu superar a abolição da escravidão sem praticamente nenhum sobressalto.

A consolidação do Partido Republicano Paulista no controle da política estadual e a liderança desse partido sobre o governo da República deu-se em um período de grande prosperidade econômica. Em 1894, a oposição jacobina se encontrava neutralizada no estado e o PRP lograra uma grande vitória, ao cooptar e neutralizar as lideranças monarquistas que vinham articulando a criação do chamado Partido Republicano Conservador. No contexto nacional, os republicanos paulistas elegeram Prudente de Morais para o governo da República e no contexto estadual a direção do partido se consolidou sob o comando de uma aliança de chefes oligarcas, que era composta por republicanos históricos e antigos monarquistas. Esse grupo dominou a política paulista até o início da década de 1900 e era liderado por Prudente de Moraes Barros, Manuel Ferraz de Campos Salles, Rodrigues Alves, Júlio de Mesquita Filho e Bernardino de Campos, essa aliança foi rompida em 1901 com o racha deflagrado por Júlio de Mesquita e Prudente de Moraes, que ocasionou a criação do Partido Republicano Dissidente.

O momento de consolidação desse grupo no controle da política paulista equivale ao período de prosperidade econômica, quando a expansão das ferrovias incorporava rapidamente novas zonas produtoras de elevada fertilidade, a lucratividade elevada permitiu o surgimento de um complexo econômico extremamente diversificado e que possibilitava inúmeras alternativas para aplicação dos lucros auferidos na produção cafeeira. Por outro lado, o estabelecimento de um fluxo intermitente de trabalhadores imigrantes permitiu aos fazendeiros paulistas, para além da substituição do trabalho escravo, manter a sua disposição uma enorme massa de trabalhadores proletarizados. Dessa forma, o imigrante europeu foi empregado em grande escala nas fazendas paulistas sem que se alterasse o regime de propriedade como temiam os proprietários envolvidos no debate sobre imigração e colonização desde a década de 1840. A alternativa de "importação" de trabalhadores chineses e indianos, tidos como mais adequados a esse regime de trabalho e que fora defendida pelo Centro da Lavoura e do Comércio no Rio de Janeiro foi prontamente rechaçada em São Paulo diante do sucesso em submeter o imigrante europeu ao regime de colonato. Sem precisar distribuir terras nem recorrer aos esquemas de meação e parceria empregados em Minas Gerais ${ }^{143}$, os fazendeiros paulistas

${ }^{143}$ LANNA, Ana Lúcia. A transformação do trabalho: a passagem para o trabalho livre na zona da Mata Mineira, 1870-1920. Campinas: Ed. Da Unicamp, 1988. 
conseguiram atrair e manter um enorme contingente de trabalhadores a sua disposição para a colheita do café, ainda que subutilizada em grande parte do ano ${ }^{144}$. Isso foi possível, sem dúvida, graças à alta lucratividade que a cafeicultura paulista apresentou entre o início da década de 1880 e meados da década de 1890, além da disponibilidade de meios de financiamento ${ }^{145}$.

Todos esses fatores contribuíam para dirimir potenciais conflitos entre os proprietários de terras.

A queda dos preços a partir de 1896 comprimiu a lucratividade da cafeicultura e alarmou os fazendeiros em todo o interior do estado, em um congresso agrícola realizado naquele mesmo ano em São Paulo, o discurso de Antônio da Silva Prado que, além de grande fazendeiro era também banqueiro e comissário de café, mostrava que o período de conciliação de interesses no complexo cafeeiro havia chegado ao fim, Antônio Prado exortava os demais fazendeiros a dedicarem mais pessoalmente a suas plantações e a não estenderem-nas em demasia e deixassem de cobrar auxílios aos governos, para acalmar os ânimos, ele afirmava que não havia verdadeiramente uma crise porque o café ainda dava lucros à maioria dos fazendeiros, ou pelo menos a baixa dos preços ainda era suficiente para cobrir os custos. Nos anos seguintes os ânimos se acirrariam, pois, enquanto uma parcela de fazendeiros cobrava medidas de combate à crise, o PRP e o ministro da Fazenda de Campos Salles era partidário da teoria de que a compressão dos lucros ocasionaria apenas a eliminação dos produtores mais fracos, o que se mostraria, inclusive, salutar para aquela economia.

Entretanto, a contração do lucro traria consequências muito mais sérias que a substituição dos proprietários.

Enquanto a margem de lucro era folgada e os fazendeiros não tinham grandes dificuldades para levantar financiamento e escoar a produção, mantinha-se uma conjunção de interesses no interior do complexo cafeeiro que se resumia em estender os trilhos das estradas de ferro e sustentar o fluxo de imigrantes para as zonas produtoras. No entanto, na medida em que a crise comprimiu a taxa de lucro surgiram novas questões que tornaram mais complexa a condução da política econômica. Os fazendeiros começaram a reclamar recorrentemente dos custos do frete ferroviário, dos juros dos

144 TESSARI, Claudia Alessandra. Braços para colheita: sazonalidade e permanencia do trabalho temporario na agricultura paulista (1890-1915), São Paulo: Unicamp, 2010.

145 DELFIM NETTO, 1981, op. cit., pp. 44-5. 
empréstimos e da dificuldade de obter financiamento. Indispondo-os com a parcela dos fazendeiros mais abastados que possuíam grande parte de sua fortuna aplicada em ações de companhias ferroviárias e bancos.

Outra grave consequência foi a interrupção do fluxo de imigrantes durante a crise, o que se mostraria bastante preocupante porque era a abundância de mão de obra que permitia a manutenção do regime de colonato. Pois, a redução do contingente de trabalhadores fazia com que aumentasse as disputas entre os fazendeiros para atrair a mão de obra disponível, elevando-se assim o valor dos salários e dos benefícios nãomonetários concedidos aos trabalhadores. Lembrando-se de que os cafezais mantinham-se em expansão e que a formação de novas fazendas era financiada com enorme facilidade graças às características dos contratos de formação ${ }^{146}$.

No sistema de parceria em que os proprietários podiam dividir com os trabalhadores os custos e os riscos da produção agrícola, enquanto no regime de colonato, como afirma Delfim Netto, era uma exploração tipicamente industrial, onde o empresário recebe a remuneração residual e o trabalhador recebe a paga de seu trabalho, quer a colheita corra bem, quer não. Diante desse quadro, em uma conjuntura de crise, o fazendeiro que adotara a parceria podia simplesmente dividir o seu prejuízo com o trabalhador, mas no sistema de colonato o fazendeiro assumia toda a responsabilidade ${ }^{147}$.

Com a crise o funcionamento do sistema de crédito e a questão dos preços do frete ferroviário foi alvo de grande controvérsia. Em relação à mão de obra ocorreram intensos debates: enquanto uma parcela dos fazendeiros exigia do Legislativo a aprovação de leis mais rígidas que permitissem a coerção dos trabalhadores, outra parcela temia que a repressão levasse à interrupção do fluxo de imigrantes, o que realmente ocorreu a partir de 1899. Entre 1899 e 1902, houve inclusive déficit na balança de entrada e saída de imigrantes, o que suscitou propostas de substituição do regime de colonato pela parceria. Em Franca, conforme demonstrou Rogério Naques Faleiros, muitos fazendeiros optaram por distribuir faixas de terras aos trabalhadores como pagamento ou lhes entregar o cafezal em regime de parceria ${ }^{148}$. Entretanto, testemunhos contemporâneos indicam que

\footnotetext{
${ }^{146}$ FALEIROS, Rogério Naques. Homens do café: Franca 1880-1920. Ribeirão Preto: Holoes, 2002.

${ }^{147}$ DELFIM NETTO, 1981, op. cit., p. 45.

148 "O colonato, dominante de fins da década de 1880 até 1897, foi paulatinamente substituído pela 'parceria' ou pela 'empreitada' (variando-se o tipo do contrato de acordo com a idade dos cafeeiros) [...]. A ausência de dinheiro, oriunda da política econômica do período, pode ser notada nos contratos de trabalho
} 
os colonos tendiam a não aceitar a parceria naquele contexto de baixa, nesse sentido, uma importante liderança cafeicultora, Candido Franco de Lacerda, chegou a sugerir que diante da recusa os fazendeiros deveriam adotar como estratégia a eliminação de $20 \%$ dos cafezais do estado, cortando os pés menos produtivos para que, ameaçados pelo desemprego, os colonos aceitassem a mudança de regime ${ }^{149}$. Por outro lado, surgia também propostas que visavam substituir o regime de "assalariamento" pela “colonização", ou seja, a oferta de parcelas de terras aos trabalhadores junto às fazendas, criando-se viveiros de mão de obra que se mantivessem disponíveis nos momentos de maior demanda ${ }^{150}$, esta era a proposta da Sociedade Paulista de Agricultura, em 1902, uma das primeiras propostas de algo que poderíamos chamar de uma "reforma agrária"151.

Por toda parte do estado, a crise econômica havia suscitado um intenso debate que abalaria o equilíbrio das forças políticas conquistado em 1894.

O debate a respeito da crise tinha como eixos a definição de sua natureza e as medidas contraditórias para resolução do problema. Divergia-se, por exemplo, se a queda dos preços era causada pelo excesso da produção brasileira adiante da capacidade mundial de consumo ou se se tratava do reflexo de uma crise conjuntural, financeira, que causara a desorganização do comércio comissário e o avanço das casas exportadoras que exerceriam pressão baixista sobre os preços.

A tese da crise como reflexo de oscilações na esfera financeira pressupunha a necessidade do comércio cafeeiro nacional intervir no mercado com ou sem auxílio do

pela substituição das cláusulas monetárias por formas de pagamento que não envolviam dinheiro [...]. O regime da parceria, dominante no Rio de Janeiro e em Minas Gerais, impõe- se na região como uma estratégia de redução dos custos e como uma tentativa de manutenção da cafeicultura num contexto de grandes dificuldades". FALEIROS, 2002, p. 120.

${ }^{149}$ Correio da Manha, 12.06.1903, p. 2; TAUNAY, A. de E., Historia do café no Brasil, v. 9, Rio de Janeiro: Dep. Nacional do Café, 1939, pp. 518-520.

150 Embora não tenha abordado essas propostas, Claudia Tessari demonstrou, analisando o calendário agrícola, que as carpas periódicas nos cafezais eram compatíveis com os trabalhos de semeadura e colheita nas culturas de abastecimento como milho, arroz e feijão. O trabalho nestas culturas ao longo do ano também não impedia a utilização dessa força de trabalho na colheita, ambas eram, na verdade, complementares. $C f$. TESSARI, 2012, op. cit., cap. II.

${ }^{151}$ A proposta de substituição do regime de trabalho aparece recorrentemente nos jornais do período e foi tratada com muito rigor por Carlos Botelho no relatório da Sociedade Paulista de Agricultura de 1902 e também em seu relatório à frente da Secretaria de Agricultura no ano seguinte. A tônica de tal proposta é a distribuição de terra aos imigrantes para que eles produzissem gêneros de abastecimentos, reduzindo-se o custo de vida, e, principalmente, mantendo-os próximos as zonas produtoras para a colheita, sem a necessidade de remunerá-los ao longo do ano como acontecia com o regime de colonato. $C f$. SOCIEDADE PAULISTA D'AGRICULTURA, COMMERCIO E INDUSTRIA. Acta da Assembléa Geral Realisada no dia 15 de julho de 1902 contendo parecer da commissão nomeada para estudar a questão relativa a limitação da plantação cafeeira e o trabalho do dr. Carlos Botelho sobre o mesmo assumpto e sobre colonisação. São Paulo: Duprat, 1902. 
Estado. As propostas nesse sentido iam desde o fortalecimento financeiro do comércio cafeeiro, passando pela compra de café realizada por um cartel de comerciantes financiado pelo governo estadual ${ }^{152}$, organização de cooperativas para venda direta de café na Europa, além da proposta de taxação de $20 \%$ in natura sobre os cafés de baixa qualidade $^{153}$ e até a queima de excedentes. Enquanto isso, os defensores da tese da superprodução, principalmente, os grupos liderados por Campos Sales, Rodrigues Alves, Prudente de Morais e Júlio de Mesquita sustentavam uma argumentação mais afeita ao laissez-faire e defendiam que a recuperação ocorreria naturalmente pelos mecanismos naturais do mercado e a eliminação dos produtores ineficientes. Nesse campo, a única intervenção estatal aceita era a propaganda do café brasileiro no exterior como meio incentivar a expansão do consumo entre povos que ainda não o bebiam ou em mercados onde o café brasileiro não tinha boa aceitação.

Paralelamente a questão da sustentação dos preços e que se estabeleceram no estrato superior da classe dos fazendeiros e nas instâncias mais elevadas do partido, havia outra ordem de propostas para solucionar a crise que refletiam os interesses dos estratos inferiores. Nessa esfera, não se discutia exatamente a solução da crise, mas as medidas destinadas a reduzir seus efeitos sobre os fazendeiros, principalmente aqueles que não tinham acesso ao sistema de crédito.

\subsection{A dinâmica do capital no complexo cafeeiro paulista}

Flávio Saes, ao analisar o desenvolvimento do sistema bancário em São Paulo, havia observado que uma parcela dos fazendeiros, geralmente membros de famílias tradicionais que haviam recebido sesmarias ainda no século XVIII, exerciam além da atividade agrícola funções comerciais e creditícias e durante o processo de expansão da cafeicultura, sobretudo a partir da década de 1870, um grupo relativamente reduzido

\footnotetext{
${ }^{152}$ LACERDA, 1897, op. cit., pp. 55-58.

${ }^{153}$ Uma proposta foi apresentada por Vicente de Carvalho e era assinada por grande número de importantes fazendeiros e comissários de café e visava reduzir os embarques de café no Porto de Santos para segurar os preços. Outra proposta foi apresentada por Quintino Bocaiuva, presidente do Rio de Janeiro, ambas foram discutidas no Congresso Legislativo de São Paulo e também pela Sociedade Paulista de Agricultura e resultariam na imposição de um imposto sobre novos cafezais, defendida por Augusto Ferreira Ramos na SPA. Cf. CARVALHO, Vicente, Solução da crise do café. São Paulo: Livraria Civilização, 1901; RIO DE JANEIRO. Valorização do café, plano apresentado pelo Governo do Estado do Rio de Janeiro. Rio de Janeiro: Typ. do Jornal do Commercio, 1902 e SOCIEDADE PAULISTA DE AGRICULTURA INDUSTRIA E COMMERCIO, 1902, op. cit.
} 
desses fazendeiros havia participado da organização de companhias de estradas e posteriormente de bancos na capital paulista ${ }^{154}$.

Diferentemente do processo observado no Rio de Janeiro, onde a incorporação de sociedades bancárias e companhias de estradas de ferro foram realizadas pelo capital comercial, em São Paulo, a realização desses empreendimentos precedeu a criação de um centro comercial poderoso o suficiente para liderar tais inversões. Com exceção do Banco Mercantil de Santos, ligado ao comércio importador e exportador, assim como a São Paulo Railway que tinha capital inglês e a Companhia Sorocabana de Estradas de Ferro, que fora organizada por comerciantes de algodão, o restante dos investimentos em companhias ferroviárias e bancos foram realizados por fazendeiros. Para denominar esse capital que não era comercial e também não podia ser chamado de agrário, Flávio Saes adotou o termo capital cafeeiro, também utilizado por Sergio Silva ao explicar a dinâmica de acumulação no complexo cafeeiro ${ }^{155}$.

Segundo esse modelo, a dinâmica de acumulação do capital no complexo cafeeiro reproduzia a hierarquização social existente, ou seja, o estrato superior dos proprietários rurais assumia funções que extrapolavam o âmbito das propriedades rurais. Ainda que mantivessem seu papel de grandes produtores de café, suas propriedades passaram a representar apenas uma parte de suas inversões, dividindo espaço com a participação em bancos, companhias ferroviárias e empreendimentos industriais. Além disso, a liderança econômica desses grandes proprietários rurais confundia-se com a sua liderança da política estadual. O estrato de fazendeiros aburguesados foi denominado por Flávio Saes como o "grande capital cafeeiro", enquanto a parcela de fazendeiros que permanecia ligada à produção agrícola fora denominada como "médio capital cafeeiro" 156.

O sistema de crédito encontrava-se igualmente hierarquizado, refletindo a organização geral do complexo. O acesso do médio capital cafeeiro era mediado, de um lado, pela atuação do capitalista nas localidades e, por outro, pelo predomínio do comissário na manutenção dos adiantamentos sobre a safra. Enquanto isso, a organização do sistema bancário estava votada para as necessidades do setor comercial do complexo

\footnotetext{
${ }^{154}$ SAES, Flavio Azevedo Marques, Crédito e bancos no desenvolvimento da economia paulista, 18501930. São Paulo: IPE, 1986.

${ }^{155}$ Cf. SILVA, Sergio, Expansão Cafeeira e Origens da Indústria no Brasil. São Paulo: Alfa-Ômega, 1995; SAES, Flávio A. M. de. A grande empresa de serviços públicos na economia cafeeira. São Paulo: Hucitec, 1986.

${ }^{156}$ SAES, 1886, A Grande empresa de serviços públicos...,
} 
cafeeiro, e nas localidades eram poucos os fazendeiros que obtinham acesso ao crédito bancário, estes, quase sempre, obtinham-no para repassar aos demais fazendeiros mediante crédito pessoal, como foi observado por Rodrigo Fantanari na localidade de Casa Branca ${ }^{157}$.

A crise afetou diretamente a relação desses fazendeiros do estrato inferior com a representação política exercida pelos grupos à frente do Partido Republicano Paulista, principalmente aqueles liderados por Rodrigues Alves e Campos Salles.

Por um lado, a queda do câmbio havia elevado os custos das companhias de estrada de ferro, levando à adoção de um sistema de correção das tarifas, que permitia às companhias de estrada de ferro corrigir automaticamente as tarifas pelo aumento dos custos em moeda estrangeira, o que despertava o descontentamento dos fazendeiros que consumiam o serviço e a contraposição de seus interesses ao dos fazendeiros que detinham ações de companhias ferroviárias. Por outro lado, o sistema de crédito transformara-se em outro foco de conflito, suscitando reclamações dos fazendeiros e a reivindicação de um sistema de crédito agrícola que se constituísse como alternativa ao crédito comercial.

A contração da taxa de lucro tinha efeito especialmente negativo para aqueles fazendeiros que mantinham seus investimentos mais restritos à exploração rural, os que ocupavam terras de menor produtividade ou simplesmente aqueles que haviam comprometido grande parte do lucro com o pagamento de juros por empréstimos de longo prazo contraídos durante a expansão.

A crise causou um choque entre as reivindicações de caráter corporativas e intervencionistas e a ortodoxia liberal dominante na política brasileira da primeira República. Para os primeiros, a gestão do Estado era coisa estranha, como lhes era estranho a capacidade de pagamento das apólices da dívida pública e a manutenção do crédito público; do mesmo modo, essas questões não lhes sensibilizavam mais do que a criação de bancos agrícolas subvencionados pelo Estado. Além disso, eles não se mostravam tão interessados em discutir se a crise era causada pela especulação ou por excesso de produção, reivindicavam, basicamente, crédito barato e trabalhadores em abundância, pois estavam mais preocupados em manter a propriedade e garantir o custeio da safra.

${ }^{157}$ FONTANARI, 2010, op. cit. 
Na medida em que o crédito concedido por comissários e capitalistas havia se restringido em função da desconfiança geral com o futuro do mercado cafeeiro, o financiamento se tornava um assunto cada vez mais importante, principalmente o crédito para o custeio da safra, o que valia tanto para o pequeno como para o grande fazendeiro enquadrado nas condições citadas acima. O agravamento da crise havia despertado estremada insatisfação com o comércio comissário e, principalmente, com o capitalista, os primeiros porque ao desconfiarem do sucesso da lavoura restringiam os adiantamentos, estes último, porque nos períodos de crise aplicavam seus recursos em atividades mais seguras que o empréstimo de dinheiro a juros, como era o caso dos depósitos bancários e os títulos públicos.

\subsection{Poder oligárquico e capital cafeeiro}

A relação entre classes sociais e representação política na primeira República foi alvo de intensa controvérsia. Para muitos autores a República velha era caracterizada pela aliança entre as classes agrícolas de Minas Gerais e São Paulo e refletia a força hegemônica desses estados diante dos demais. Por outro lado, surgiram diversas críticas a estas interpretações, principalmente no ponto em que elas valorizavam o predomínio dos fazendeiros de café na formatação da política econômica do Estado brasileiro. Nesse mesmo sentido vários autores ressaltaram que a utilização de termos como oligarquia ou burguesia cafeeira mitigavam os conflitos no interior das elites estaduais transformandoas em blocos monolíticos ${ }^{158}$.

Boa parte dessas críticas articulou-se em torno do texto de Boris Fausto "Expansão do Café e Política Cafeeira", que foi publicado na coletânea História Geral da Civilização Brasileira $^{159}$. Boris Fausto entendia que tanto a dinâmica da economia cafeeira como a “política do café" explicavam-se pelo predomínio e hegemonia da burguesia do café no plano interno e sua dependência do capitalismo internacional no plano externo ${ }^{160}$. O autor não ignorava a existência de conflitos na gestão da economia agroexportadora, entretanto, sua análise os transferia para âmbito das disputas inter-regionais, as disputas entre as oligarquias dos diversos estados no conjunto da República e sobre as quais o interesse

${ }^{158}$ Cf. MENDONÇA, Sonia Regina de, O Ruralismo Brasileiro: 1888-1931, São Paulo: Hucitec, 1997 e PERISSINOTO, Renato M, Classes Dominantes e Hegemonia na República Velha, Campinas: Ed. Unicamp, 1994.

${ }^{159}$ FAUSTO, Boris. "Expansão do Café e Política Cafeeira". Boris FAUSTO (org.) História Geral da Civilização Brasileira. Tomo III: "O Brasil Republicano". São Paulo: Difel, 1985.

${ }^{160}$ Idem, ibdem, p. 195. 
cafeeiro exercia uma liderança. Nesse sentido, dizia Boris Fausto, que as forças sociais se compõem das diversas oligarquias regionais onde a oligarquia paulista exerce uma função hegemônica, a partir da aliança básica com a oligarquia mineira ${ }^{161}$.

Para o autor, a liderança dos fazendeiros paulistas teria se iniciado em 1894 com a eleição de Prudente de Moraes e se consolidaria em 1898 com a eleição de Campos Salles e a instituição da política dos governadores, o que se dera de acordo com o seguinte modelo:

Se a oligarquia paulista representava os interesses de classe dos fazendeiros de café - a burguesia cafeeira - como consequência esta oligarquia ao exercer uma hegemonia sobre as demais deveria impor seu interesse de classe na gestão da política econômica republicana.

No âmbito da política econômica, embora o complexo cafeeiro paulista dependesse da política monetária e externa da República, a importância que o café exercia sobre a receita de divisas afetava todo o conjunto da República, principalmente o comportamento da taxa de câmbio.

É certo que as oligarquias agroexportadoras dos demais estados também se beneficiavam da nova organização administrativa, mas certamente nenhuma delas obteve tantos benefícios quanto a paulista. No entanto, a análise das reformas econômicas mais importantes do período levou muitos autores a questionar até que ponto era o interesse dos cafeicultores que se impunha sobre as medidas adotadas pelos governos republicanos. Embora a reforma monetária de 1890 se justificasse pelas novas dificuldades advindas do trabalho livre, como o pagamento de salários e a aceleração das transações comerciais, ela não foi reivindicada pela elite paulista, refletia, pelo contrário, muito mais os interesses relacionados à praça comercial do Rio de Janeiro ${ }^{162}$.

Além disso, entre 1894 e 1906, o governo federal esteve sob controle direto do Partido Republicano Paulista, no entanto, não se pode afirmar que as medidas econômicas adotadas por esses governos refletissem diretamente o interesse dos fazendeiros paulistas, muito pelo contrário, elas haviam causado grande descontentamento nos fazendeiros de café de São Paulo, o que claramente ocorrera em relação à reforma monetária aplicada durante o governo de Campos Salles.

\footnotetext{
${ }^{161}$ Idem, ibdem, p. 195.

${ }^{162}$ Segundo Joseph Love, na aplicação da reforma bancária de Rui Barbosa, não previa nenhum banco de emissão em São Paulo e a inclusão da autorização que fora concedida ao Banco União de São Paulo foi possível pela intervenção de Campos Sales. $C f$. Love, op. cit., p. 251 e nota.
} 
Boris Fausto não deixou de notar a contradição encerrada entre a política monetária recessiva e o interesse dos fazendeiros paulistas. Afinal, como poderia um governo liderado pela burguesia cafeeira paulista ter aplicado uma política que pareceu tão odiosa à sua própria base?

A este respeito, o autor afirma que:

O paradoxo é apenas aparente quando se têm em conta três elementos interligados: a lógica do sistema econômico que, em situações críticas, tem maior importância do que a origem regional do presidente; o caráter dependente da classe hegemônica; a distinção entre interesses corporativos e políticas de uma classe social ${ }^{163}$.

No entanto, o problema não é tão simples e a contradição não era apenas aparente, pois as alas dominantes no Partido Republicado Paulista, representadas por Prudente de Moraes, Campos Salles, Rodrigues Alves e Bernardino de Campos, amargariam um enorme desgaste político nos anos seguintes.

Outro ponto de conflito foi o plano de valorização do café colocado em prática em 1906. A aprovação do convênio de Taubaté, durante o governo Rodrigues Alves, e a aplicação do plano de valorização durante o governo do mineiro Afonso Pena, foram fatores responsáveis pela noção de que a política econômica do período refletia o interesse de fazendeiros representados no comando do governo federal. A noção de um acordo entre as oligarquias estaduais parecia clara nesse momento, dado que o processo havia se iniciado durante a presidência do paulista Rodrigues Alves e a valorização foi implantada por seu sucessor, o mineiro Afonso Pena. No entanto, análises mais atentas, como a de Thomas Holloway ${ }^{164}$, demonstrariam o contrário, desde 1896 as propostas de intervenção no mercado cafeeiro e as reivindicações de auxílio aos fazendeiros prejudicados pela crise foram rechaçadas pelo PRP, tanto no âmbito da presidência do estado de São Paulo como no do governo da República.

A recusa do grupo hegemônico do partido em socorrer os fazendeiros e intervir nos preços do café, usando-se, inclusive de argumentos considerados ofensivos como o da seleção natural pela destruição dos mais fracos, somada à reforma monetária de 1898 que causou grande retração no crédito, contrariavam demasiadamente os fazendeiros paulistas. A oposição interna aos grupos no comando do PRP adquiriu enorme força em

163 FAUSTO, 1985, op. cit., p. 207.

${ }^{164}$ HOLLOWAY, Thomas H. Vida e Morte do Convenio de Taubaté, Rio de Janeiro, Paz e Terra, 1978. 
1899 e a insatisfação foi catalisada em torno das propostas de criação do Partido da Lavoura, onde lideranças de monarquistas, jacobinos e republicanos aproveitaram o clima de insatisfação na base eleitoral do PRP e ameaçaram lançar candidaturas dissidentes ao executivo e legislativo.

O ímpeto oposicionista começou a ser desfeito ainda durante a presidência estadual de Rodrigues Alves (1900-1902) e continuado por Bernardino de Campos (19021904), porém, a inflexibilidade doutrinária não permitiria ao partido e ao governo ceder aos apelos intervencionistas e o descontentamento se intensificaria durante a gestão de Jorge Tibiriçá (1904-1906). Este, por sua vez, cedeu definitivamente às pressões de intervenção econômica e, posteriormente, reformou o Partido Republicano.

Tibiriçá costurou um acordo com uma das alas da oligarquia mineira, viabilizando assim a assinatura do Convênio de Taubaté (no início de 1906), impondo, ao mesmo tempo o plano de valorização ao governo federal.

Rodrigues Alves, que ocupava a presidência da República, permanecia obediente aos princípios dos laissez-faire e manteve-se firme na recusa em avalizar a execução do plano de valorização. Como resultado, Rodrigues Alves, que costurava dentro do partido a candidatura de Bernardino de Campos como seu sucessor, viu-se obrigado a ceder à candidatura ao mineiro Afonso Pena, que contava com grande apoio no estado de São Paulo. A escolha de Bernardino deveria completar o ciclo das principais alas do partido na presidência da República, dando sequência a Prudente de Morais, Campos Salles e Rodrigues Alves. Mas Bernardino teve de desistir de sua candidatura e o PRP acabou fechando apoio a Afonso Pena. Eleito presidente, o mineiro entregou o ministério da Fazenda a David Campista, um dos negociadores do plano de valorização e idealizador da Caixa de Conversão. O novo governo assumiu a tempo de aprovar o aval necessário à consecução do plano para a safra daquele ano ${ }^{165}$.

Como se vê a elite cafeeira paulista não era um bloco monolítico, as alas que compunham o grupo no poder possuíam grande coesão, mas isso não significava que elas atendessem aos interesses dos fazendeiros de café. A razão do tratamento dessa elite como um bloco homogêneo residia em dois fatores: em primeiro lugar, o predomínio do Partido

${ }^{165}$ Cf. HOLLOWAY, Vida e Morte do Convenio de Taubaté, Rio de Janeiro: Paz e Terra, 1978; CARONE, 1972, op. cit.; SAES, 1986, op. cit.; SOARES JÚNIOR, Rodrigo, Jorge Tibiriçá e sua Época, Cia. Ed. Nacional, 1958; KUGELMAS, Eduardo. A difícil hegemonia, um estudo sobre São Paulo na primeira República. São Paulo: FFLCH-USP (Tese do Doutorado), 1987. 
Republicano Paulista e, em segundo, o fato de essa elite política ser composta, quase que na sua totalidade, por proprietários produtores de café. Entretanto, ser proprietário de terras e produtor de café em São Paulo não era atividade que permitisse distinguir um indivíduo, pois, desde os comissários de café, passando pelos acionistas e diretores de companhias ferroviárias, banqueiros e até mesmo grande parte dos industriais eram fazendeiros.

Diferentemente de Boris Fausto, Sergio Silva e Flávio Saes interpretaram as disputas em torno da política econômica no contexto do complexo cafeeiro paulista como o resultado de um distanciamento entre os interesses de uma parte da elite cafeicultora o "grande capital cafeeiro" - cujo capital estava investido em diversas aplicações que extrapolavam a esfera produtiva e que se contrapunham aos interesses daqueles fazendeiros que se mantinham ligados apenas ao cultivo do café - o "médio capital cafeeiro" 166 .

É indispensável citar aqui o exemplo de dois casos emblemáticos de fazendeiros que exerciam múltiplas atividades no complexo cafeeiro. O primeiro é Antônio de Lacerda Franco, ligado inicialmente ao cultivo de cana e gêneros de abastecimento, que se tornou sócio em casa comissária, acionista de companhia ferroviária e, na década de 1890, fundou o Banco União de São Paulo, que tinha participação em empresas comerciais e dirigia diretamente uma série de empreendimentos industriais, entre eles, a Indústria Têxtil Votorantim, em Sorocaba, uma das maiores fábricas de tecidos de São Paulo. Lacerda Franco fora deputado estadual, deputado federal e na vida partidária era representante de Bernardino de Campos na Comissão Central do Partido Republicano Paulista. Outro importante representante desse grande capital era Antônio da Silva Prado, um dos maiores fazendeiros de café de São Paulo que, ao mesmo tempo, dirigia a casa comissária e exportadora Prado, Chaves \& Cia, a maior do país, controlava vários empreendimentos como a Fábrica de Vidros Santa Maria, um frigorífico em Barretos,

\footnotetext{
${ }^{166}$ A noção de grande e médio capital cafeeiro foi proposta por Sérgio Silva em 1975, dentro do debate onde João Manoel Cardoso de Mello e Wilson Cano buscavam demonstrar como o desenvolvimento da cafeicultura paulista havia possibilitado o transbordamento da renda gerada na produção cafeeira para o setor urbano e industrial daquela economia, reformulando, assim, a teoria de Celso Furtado em que este autor propunha que a industrialização apenas se realizaria nos momentos de crise da economia agroexportadora. Cf. CANO, 1981, op. cit.; MELLO, João M. C. de. O Capitalismo Tardio, Rio de Janeiro: Brasiliense, 1987; SAES, 1986. A Grande Empresa de serviços públicos...; SILVA, Sergio, Expansão Cafeeira e Origens da Industria no Brasil, São Paulo, Alfa-Omega, 1995.
} 
além de ter ocupado a presidência da Cia. Paulista de Estradas de Ferro e o controle do maior banco paulista do período, o Banco Comércio e Indústria de São Paulo.

Exemplos como esses se repetem abundantemente na historiografia paulista, tais como Joaquim Egydio de Souza Aranha, Antonio Carlos Botelho (Conde do Pinhal), Francisco Ignácio de Souza Queiroz, Manuel Rodrigues Jordão, Nicolau Vergueiro, entre outros, tratados muitas vezes como simples fazendeiros.

Como vimos anteriormente, o conflito entre grande e médio capital cafeeiro seria capaz de explicar as divergências e contradições das posições dos paulistas no governo estadual e federal, dado que as políticas monetárias, cambial e de crédito tinham repercussões diferentes nos diversos setores da economia, inclusive entre diversas categorias de proprietários rurais, e a sua adesão dependia do posicionamento social dos indivíduos no interior do complexo cafeeiro.

A tese do distanciamento entre grande e médio capital cafeeiro parece explicar satisfatoriamente a natureza dos conflitos em torno da política econômica na primeira República. Entretanto, mais recentemente, Renato Perissinotto buscou utilizar essa mesma tese para explicar a natureza dos conflitos políticos ocorridos em São Paulo. Para esse autor, as dissidências refletiam diretamente o conflito originado no processo de reprodução do capital cafeeiro e as propostas de criação de um partido da lavoura, como um partido que atendesse às reivindicações dos fazendeiros prejudicados pela crise, seriam a expressão direta de uma tomada de consciência do médio capital cafeeiro, enquanto fração autônoma de classe ${ }^{167}$. Entretanto, é preciso ponderar que Sérgio Silva não havia tomado "o médio capital cafeeiro" como um grupo autônomo e tão pouco Flávio Saes indicava ser a lavoura uma fração autônoma de classe, embora tenha demonstrado a existência de conflitos entre ambos e a ligação entre esses conflitos e as propostas de criação de um partido da lavoura.

Tomando a formação dos partidos na primeira República por um outro prisma, como o fez Edgard Carone, devemos nos ater ao fato de que os partidos políticos naquele período não se organizavam como partidos de classe, visto que a organização social e política estava marcada pelo chamado compromisso oligárquico. Desse modo, não poderíamos, conceber os partidos republicanos como expressão da classe como fez Perissinotto, diferentemente, como nos sugere Carone, esses partidos eram expressão da

${ }^{167}$ PERISSINOTO, 1994, op. cit. 
oligarquia de cada estado e não da classe dos fazendeiros, e o comando da política estadual era exercido por um pequeno número de chefes estaduais que negociavam o poder com os chefes políticos nas localidades, os coronéis ${ }^{168}$.

No que diz respeito à classe dos fazendeiros, enquanto autores como Boris Fausto, Wilson Cano e Sérgio Silva compreendem a classe dominante no complexo cafeeiro como uma burguesia cafeeira, Edgard Carone entendia como burguesia a classe dos industriais, banqueiros e grandes comerciantes citadinos. Desse modo, à primeira vista, parece haver grande incompatibilidade entre a noção de burguesia de Carone e a dos autores que aderiram à noção de complexo cafeeiro, assim como pode parecer que Carone ignorava a superposição das atividades de fazendeiro e empresário urbano observada em relação aos postulantes ao rótulo de burgueses citadinos. Entretanto, pudemos observar que Carone não ignorava que as funções de banqueiro e fazendeiro se encontravam misturadas em um mesmo indivíduo, ele demonstrou isso ao afirmar que a camada mais dinâmica de fazendeiros dedica-se a atividades industriais, comerciais e bancárias, transformando a organização agrícola em uma forma organizatória paralela àquela que desenvolvem nas cidades ${ }^{169}$.

Vê-se, portanto, que aquilo que Carone chamou de burguesia é a mesma burguesia cafeeira abordada por Sergio Silva e que Flávio Saes chamará mais tarde de grande capital paulista. Para Carone, essa camada mais dinâmica da classe dos fazendeiros se sobrepunha a uma extração inferior que permanecia ruralizada. De acordo com esse autor, mesmo entre fazendeiros do oeste paulista, podem-se distinguir camadas mais tradicionais, que continuam a se prender ao modo de vida rural e, com a decadência dessas zonas, nelas permanecem, ruralizando-se totalmente ${ }^{170}$. Por outro lado, se podemos perceber que Carone não ignorava a superposição dos papéis de fazendeiro e industrial nos mesmos indivíduos, é flagrante também que ele não se aprofundou na compreensão do que seria a burguesia paulista, tão pouco naquilo que ele chamou genericamente de "classes agrícolas", concentrando sua análise no papel da oligarquia.

A oligarquia era a expressão de um sistema político que não se orientava pelos vínculos de classe, mas pelo predomínio de ligações patriarcais e de apadrinhamento. Os líderes políticos, os oligarcas, eram os chefes de verdadeiros clãs políticos que defendiam

${ }^{168}$ CARONE, 1972, op. cit.

169 Idem, ibdem.

${ }^{170}$ Idem, ibdem., p. 149. 
seus interesses como representantes da extração superior da classe dos proprietários rurais, porém, sua liderança contava com a adesão de diversos outros grupos. Na base desse sistema estavam os chefes políticos locais, muitas vezes investidos na patente de coronel da Guarda Nacional. O poder político do oligarca estaria baseado nos favores que, enquanto integrantes do governo estadual, concediam aos chefes políticos locais que, em troca desses favores, oferecia os votos de que necessitava o oligarca e que ele controlava firmemente ${ }^{171}$.

O oligarca seria então um chefe político de importância estadual enquanto o coronel tinha sua importância restrita à localidade. O oligarca e o coronel ocupavam duas esferas distintas de poder, a da política estadual e a da política local.

Em tal sociedade, o governo se confundia com o partido dominante, e este com as classes agrárias. Por isso, segundo Carone, esse regime não permitia a existência de oposições permanentes e as tensões geradas entre as diversas alas da oligarquia, entre os diversos chefes estaduais, e também na base coronelista acabavam sempre na formação de dissidências transitórias.

Ao longo da década de 1980, vários autores que se voltaram à explicação da política econômica na primeira República procuraram explicar a participação política da elite econômica eliminando o interesse de classe. Para esses autores, a gestão do Estado apresentaria demandas específicas da ação governamental, e o grupo político dominante funcionaria como uma corporação gestora, com interesses próprios, afastada de sua base social. O ponto de articulação dessas teses girou em torno de eventos em que se podia verificar um descompasso entre as políticas adotadas pelos governos e as classes sociais que davam sustentação ao poder político, o que refletiria demandas institucionais oriundas da gestão do Estado e não o compromisso de classe. Boris Fausto respondeu às essas críticas em um artigo publicado em 1990 com o título "Estado e Burguesia Agroexportadora na Primeira República: Uma Revisão Historiográfica”, no qual afirmou que o aparente descompasso das relações entre Estado e classes sociais não se devia ao deslocamento do vínculo de classe, mas ao fato de que elas também tinham conflitos internos e que, além disso, elas não conseguiam controlar completamente o Estado e tinham de dividi-lo com outros grupos de interesse ${ }^{172}$.

\footnotetext{
${ }^{171}$ Idem, ibdem.

172 FAUSTO, Boris, "Estado e burguesia agroexportadora na Primeira República: uma revisão historiográfica". Novos Estudos Cebrap, v. 27, 1990, p. 127.
} 
Enquanto a dinâmica de acumulação do capital cafeeiro repunha, constantemente, a hierarquização econômica no seio da classe agrária, a conformação oligárquica do poder político fazia com que o poder aparecesse repartido em duas esferas: uma estadual, oligárquica, e outra local, onde predominava o coronel. O regime oligárquico apresentava uma barreira à representação direta dos interesses de classe. É certo, porém, que a representação política é sempre permeada de mediações diversas, mas nesse caso ela adquiria contornos mais enrijecidos, gerando tensões que se acentuaram durante a crise cafeeira de 1896-1906.

Não nos parece possível identificar o núcleo do PRP ao grande capital cafeeiro e, como veremos a seguir, o Partido da Lavoura não era composto apenas pelo médio capital cafeeiro, ainda que se articulasse em torno de uma agenda que favorecia os fazendeiros e reivindicasse o papel de legítimo representante da lavoura do estado diante dos interesses estranhos do grupo dirigente. Por outro lado, é evidente que a direção do PRP à frente do governo federal tomou medidas que eram convenientes ao grande capital, mas não só a este, pois sofria pressão tanto de sua base social, ainda que mediada pelo compromisso oligárquico, como pelos interesses de outras elites estaduais e do capital estrangeiro. As cisões que culminaram no surgimento dos partidos dissidentes durante a crise cafeeira e que exprimiam o descontentamento com a política econômica, embora estivessem articuladas em torno da questão dos auxílios à lavoura e refletissem a insatisfação do médio capital cafeeiro, estavam também permeadas pela disputa oligárquica e muitos dos dissidentes que se colocavam como legítimos representantes da "classe da lavoura" eram, na verdade, chefes oligarcas alijados pelo grupo no poder, sem falar dos monarquistas e jacobinos.

A maior expressão do poder oligárquico era a composição da Comissão Central do Partido Republicano, órgão mais importante do partido que definia os candidatos à presidência do Estado e as listas de candidatos à câmara e ao senado e era composta pelos principais chefes oligárquicos do Estado. Sua composição variou entre cinco e nove membros ao longo da Primeira República, quando os líderes oligárquicos não podiam ocupar seus lugares na comissão, eles indicavam representantes, desse modo, em 1901, a Comissão era composta por Frederico Abranches (representante de Rodrigues Alves), José Alves Guimaraes Jr (representante de Prudente de Moraes), Alfredo Guedes (representante de Cerqueira Cesar), Pádua Salles (representante de Campos Salles) e 
Antonio de Lacerda Franco (representante de Bernardino de Campos) ${ }^{173}$. Muitos chefes oligárquicos estavam apartados do poder estadual, muitos eram monarquistas, outros republicanos alijados do poder estadual ${ }^{174}$.

A máquina partidária impedia a sobrevivência de candidaturas que oferecessem risco à oligarquia na medida em que ela controlava os chefes locais que, por sua vez, exerciam pressão sobre os eleitores, geralmente utilizando-se da violência. O chefe local se mantinha no poder do município pelo voto de cabresto e também pelas benesses concedidas pelo governo estadual ${ }^{175}$.

Os candidatos ao Congresso Legislativo e ao governo estadual não conquistavam o voto diretamente aos eleitores, mas por meio de negociações com os coronéis. No entanto, esse processo não era estático e, constantemente, ocorriam divisões que colocavam em oposição os postulantes à chefia local. As dissidências periódicas, quase sempre lideradas por indivíduos alijados momentaneamente do processo político, apoiavam-se nessas divergências que se mostraram sempre reversíveis e que muito dificilmente abalavam o conjunto do regime oligárquico.

\subsection{A conformação do poder oligárquico: o PRP a e suas dissidências}

A primeira década da República foi um período bastante conturbado para os republicanos de São Paulo. O grupo que no fim da década de 1890 liderava a política do Estado era encabeçado por Prudente de Moraes, Júlio de Mesquita, Cerqueira Cesar, Jorge Tibiriçá, Campos Salles, Bernardino de Campos e Rodrigues Alves; segundo Edgar Carone, cada um desses indivíduos liderava uma das alas que comandavam o Partido Republicano Paulista, tendo ocupado os cargos mais importantes da política estadual e federal. A consolidação desse grupo no controle do processo político do estado deu-se entre 1890 e 1894, pelo enfraquecimento dos militares no Estado e pela dissuasão dos

\footnotetext{
${ }^{173}$ Idem, p. 271-273

${ }^{174}$ Eram monarquistas, entre muitos outros, o Conde do Pinhal, Antonio Cândido Rodrigues e o Barão Geraldo Rezende e estavam à frente das tentativas de criação do Partido Republicano Conservador e também na liderança do Partido da Lavoura. Outros monarquistas, mesmo não aderindo ao republicanismo, aceitaram a conformação do poder sob a liderança do Partido Republicano; este era o caso de Antonio da Silva Prado, importante político do império, mas que resolveu não se opor ao governo republicano, pelo contrário, dissuadiu em várias ocasiões os monarquistas de criarem um partido de oposição, no entanto, optou por se resignar politicamente no que dizia respeito ao comando da política estadual e só voltou a disputá-la na década de 1920 ao assumir a liderança do Partido Democrático. $C f$. LEVI, Darrell E.A família Prado. São Paulo: Cultura, 1977

${ }^{175}$ LEAL, Victor Nunes, Coronelismo Enxada e Voto (O município e o Regime Representativo no Brasil), São Paulo, Companhia das Letras, 2012.
} 
antigos membros do Partido Conservador do império de constituírem um partido republicano em oposição ao Partido Republicano Conservador.

No início do período republicano os estados se viram imersos em lutas intensas entre republicanos históricos, monarquistas e republicanos de última hora. $\mathrm{O}$ grupo à frente do Paulista Republicano Paulista tinha a maior força política da República e era secundado pelos militares, denominados jacobinos, cuja força estava concentrada na capital federal. Essa tendência buscou desestabilizar os republicanos paulistas por meio de alianças com elementos oriundos do antigo Partido Conservador e republicanos que rejeitavam o grupo no comando do PRP. Pode se dizer que os primeiros cinco anos da República foram de fortalecimento daquele grupo à frente do PRP no controle da política estadual.

A aliança que consolidou esse grupo no controle do PRP deu-se quando Prudente de Moraes conseguira viabilizar sua candidatura à presidência da República, em 1891, contra os militares deodoristas. Em São Paulo, Prudente contava, incialmente, com a oposição de Bernardino de Campos e de Campos Salles. Depois de vencer a objeção de Bernardino e Campos Salles, o partido se unificou em torno do nome de Prudente de Moraes, formando uma chapa de candidatos a deputados que tinha quatro nomes conservadores, Antonio da Silva Prado, José Luis de Almeida Nogueira, Rubião Jr. e Rodrigues Alves.

Paralelamente, um grupo importante de monarquistas oriundos do Partido Conservador que havia anunciado sua adesão ao republicanismo articulava em sigilo a criação de um partido de oposição ao PRP, o Partido Republicano Conservador que deveria agrupar monarquistas ainda resistentes; entre eles, estavam o Barão de Jaguará, Barão de Souza Queiroz, Bernardo Gavião Peixoto, Frederico Abranches, Marques de Três Rios e Augusto de Souza Queiroz ${ }^{176}$. Nesse momento, Antônio Prado usara de seu prestígio entre os conservadores e conseguiu dissuadi-los de organizar tal partido e a resistência monarquista ao PRP foi mantida sobre controle por alguns anos, assim, o principal foco de divergência era mantido pelos jacobinos, principalmente Américo Brasilense.

${ }^{176}$ CASALECCHI, José Ê. O Partido Republicano Paulista (1889-1926), São Paulo, Brasiliense, 1987, p. 65. 
Em 7 de março de 1891, Deodoro depôs o presidente do Estado, Jorge Tibiriçá, e indicou para o seu lugar Américo Brasiliense que governaria com forte oposição do Congresso Legislativo, mas que contava com aliados importantes no interior do Estado. No mês de novembro de 1891, os republicanos históricos assistiam apreensivos aos acontecimentos que se sucediam no Rio de Janeiro, com o golpe promovido pelo Marechal Deodoro contra o parlamento. Nesse momento o governo paulista apoiava Deodoro, mas a maior parte do Partido Republicano apoiava Floriano que planejava um contragolpe.

Em novembro estourava a revolta da armada e Floriano obteve a renúncia de Deodoro que repercutiria imediatamente sobre o governo paulista, provocando a renúncia de Américo Brasiliense. Os republicanos históricos elegeram Cerqueira Cesar para seu lugar e, pela primeira vez, o PRP mantinha o controle do governo estadual e contava com o apoio do governo federal ${ }^{177}$. Em 1893, depois de uma longa negociação, Prudente conseguiu viabilizar seu nome para a sucessão de Floriano Peixoto.

Dado que as chapas para escolha dos candidatos eram indicadas pela comissão executiva, havia poucas possibilidades de surgirem candidaturas divergentes e mesmo que conseguissem passar por aquele filtro, era necessário enfrentar eleições realizadas em redutos controlados pela máquina partidária. Na medida em que o PRP, liderado pelos republicanos históricos, conseguia estabilizar o processo político, o controle dos municípios se transformava num importante espaço de disputa, visto que o controle dos diretórios municipais dava ao chefe político local poder para negociar com a direção estadual do PRP. Os jornais também se tornaram elementos cada vez mais importantes, pois a imprensa não estava submetida ao controle estrito do grupo dirigente.

O período que se inicia em 1895 foi de grande agitação no interior do partido, em que o grupo dirigente passou a ser recorrentemente contestado. Em março de 1895, Candido Rodrigues, Paulino de Lima e Rodolfo Miranda lançavam mão mais uma vez do Partido Republicano Conservador e, Cesário Motta, Secretário do Interior no governo Bernardino de Campos lançara o Partido Republicano de Oposição. No mesmo ano, o general Francisco Glicério, que promovera um racha no interior do Partido Republicano Federal se indispunha com Prudente de Moraes.

${ }^{177}$ Idem, ibdem, p. 65. 
Nesse momento, tramitava um projeto no Congresso Legislativo que visava limitar a autonomia municipal. Contra esse golpe, o general Francisco Glicério (jacobino) unia-se ao Partido Conservador de Cândido Rodrigues (monarquista) e a outros republicanos insatisfeitos, como Washington Luís, na defesa das municipalidades. O combate ao PRC veio por meio de uma campanha de cooptação das lideranças descontentes nas localidades e que conseguiu conter o seu avanço: segundo José Ênio Casalecchi, o situacionismo envolve e derrota os gliceristas através de consertada ação nas bases municipais.

Até aqui as disputas ocorriam em decorrência da luta por espaços no governo e na definição das sucessões do governo federal e os principais focos de oposição aos históricos surgiam daquelas lideranças que se associavam aos militares, como foi o caso de Américo Brasiliense (aliado de Deodoro) e Francisco Glicério (com Floriano Peixoto). Mas, em 1895, os militares estavam contidos e seus aliados em São Paulo enfraquecidos, entretanto, a crise econômica forneceria um novo combustível para a oposição e fomentava as dissensões políticas.

Após a reforma financeira implementada no governo de Campos Salles, o clima de insatisfação aumentava e surgia com grande força a proposta de criação do Partido da Lavoura, cujo o programa era a defesa dos interesses agrários em oposição aos interesses comerciais do complexo cafeeiro que estavam representados no comando do PRP. Em 1899, o jornal Correio Paulistano, que até então cumpria a função de órgão oficial do PRP, passou a fazer propaganda em favor do Partido da Lavoura, somando-se ao campo oposicionista onde já se encontrava o jornal monarquista O Comércio de São Paulo. Luiz Piza, que era diretor do Correio Paulistano e membro da Comissão Central do PRP chegou a ser advertido pelo partido por apoiar os dissidentes ${ }^{178}$.

Na prática, entretanto, a formação de dissidências era transitória e a atuação desses partidos consistia em estabelecer alianças com chefes locais em diversas localidades que por algum motivo estavam insatisfeitos com o comando do PRP. Se conseguissem organizar-se em uma grande quantidade de municípios, obtendo o controle do processo eleitoral local, os dissidentes obtinham poder de barganha para negociar com a Comissão Central a inclusão de seus candidatos na lista do Partido Republicano. Daí a importância do controle das localidades e a cooptação dos coronéis insatisfeitos para o lado dissidente.

${ }^{178}$ Idem, ibdem, p. 99, nota 90. 
Por isso, ao longo das primeiras décadas da República, o governo paulista buscou constantemente limitar o poder das câmaras municipais, como meio de enfraquecer os municípios e poder controlá-los mediante a distribuição de verbas ${ }^{179}$.

A dissidência que se organizou em torno do Partido da Lavoura ganhou força em 1899 e passou a contar com o apoio de monarquistas e jacobinos e pela primeira vez surgia uma força capaz de dividir os votos com o PRP em dezenas de localidades. O Partido da Lavoura acabou se esvaziando devido à cooptação de muitas de suas lideranças durante a gestão de Rodrigues Alves à frente do governo paulista, que indicou, por exemplo, Cândido Rodrigues, um antigo oposicionista, para o cargo de secretário de agricultura.

Enquanto ao longo de 1900 os republicanos à frente do PRP conseguiram trazer para o seu campo dissidentes e oposicionistas que haviam liderado a criação do Partido da Lavoura, uma nova dissidência ameaçava a unidade da oligarquia paulista; dessa vez, não se tratava de grupos alijados do processo político, mas de um importante grupo reunido em torno da liderança dos históricos Prudente de Morais e Júlio de Mesquita e a origem dessa cisão remonta à eleição de Campos Salles, em 1898. Desde a posse de Campos Salles, Prudente de Moraes reclamava que seus representantes na Comissão Central do PRP estavam isolados do processo decisório. Na origem do problema, estava o ressentimento de Campos Salles com Prudente de Morais pelo fato de ele não ter se empenhado suficientemente na candidatura de seu sucessor ao governo do Estado, Rodrigues Alves. Durante o processo de escolha, Campos Salles havia indicado o nome de Rodrigues Alves, desagradando a Júlio de Mesquita (aliado de Prudente na Comissão Central) que apoiava a indicação de Cerqueira Cesar. Cedendo às pressões de Prudente, Campos Salles reorganizou a Comissão Central do partido, mas usou do poder de barganha para manter a candidatura de Rodrigues Alves ${ }^{180}$.

Nas eleições para o executivo estadual, realizadas em janeiro de 1900, embora Campos Salles tenha desafiado Júlio de Mesquita e Prudente de Morais, ele obtivera habilmente um acordo com as lideranças do Partido da Lavoura para que não lançassem candidato próprio como era pretendido, nem atrapalhassem o pleito que escolheria Rodrigues Alves. Após o incêndio provocado pelo Partido Lavoura nas hostes do partido em 1899 ter sido controlado, Prudente e Júlio de Mesquita desencadearam uma nova cisão

${ }^{179}$ Cf. CASALECCHI, op. cit., pp. 99-100 e LEAL, 2012, op. cit.

${ }^{180}$ Idem, ibdem, pp. 100-103. 
em 1901. Esse conflito nada tinha a ver com as reivindicações da lavoura frente a crise, pois se tratava muito mais de uma discordância sobre a questão sucessória ${ }^{181}$.

Em novembro foi publicado o Manifesto do Partido Republicano Dissidente, que contou com assinatura de delegados de 106 das 162 localidades do Estado ${ }^{182}$. Embora a historiografia costume descrever esse racha como o mais importante até a década de 1920, é preciso relativizar o seu alcance, pois a sua importância residia muito mais no cacife político de seus participantes, mas que não foi suficiente para contagiar a base social do PRP. Como lembra Casalecchi, os dissidentes obtiveram um resultado pífio nas eleições municipais de dezembro de 1901, mostrando como era grande o poder de repressão do PRP sobre as bases locais. Mesmo contando os dissidentes de 1901 com poderosos e influentes membros da oligarquia, tais como Cerqueira Cesar, Prudente de Moraes e Júlio de Mesquita, dos oitenta municípios onde PRD apresentou candidaturas, ele saiu vitorioso em apenas três: Piracicaba, Ribeirão Bonito e Mogi Mirim ${ }^{183}$.

Entre 1902 e 1906, o governo paulista se voltaria ao trabalho de incorporação dos líderes oligarcas dissidentes e à oposição monarquista e militar no interior do Partido Republicano Paulista, enfraquecendo, definitivamente, as forças centrípetas que, desde 1890, ameaçavam a hegemonia do PRP com a criação dos partidos Conservador, Monarquista e da Lavoura e, mais tarde, reincorporando também as lideranças que haviam criado o Partido Republicano Dissidente. Na condução desse processo foi de enorme importância o controle que o governo e o seu partido conseguiram estabelecer sobre os canais de manifestação das oposições e dissidências, não apenas por meio do cerceamento das câmaras municipais como havia indicado Edgar Carone, mas também impedindo a organização das associações agrícolas.

Como veremos a seguir, a criação de sociedades de agricultura, inspiradas nas société de agriculture francesas, transformara-se em um veículo muito eficiente para arregimentação dos chefes locais. Com a eleição de delegados locais para participar de congressos e associações em âmbito estadual, a oposição conseguia vencer o isolamento no qual se encontravam os chefes políticos das localidades, criando espaços de representatividade que funcionavam como alternativa ao Partido Republicano e que

${ }^{181}$ CASALECCHI, op. cit., p. 100-16.

182 O programa do novo partido foi organizado por Antonio Mercado, Cesário Bastos, Cincinato Braga, Ignácio Uchoa e Julio de Mesquita, que propunham resgatar os princípios da Convenção de Itu e combater o mandonismo pessoal dos chefes políticos.

${ }^{183}$ Idem, p. 111. 
chegaram a se organizar enquanto partido. O governo paulista buscou esvaziar a organização de tais associações de lavradores, como fez com a Associação dos Lavradores Paulistas, criada em 1896, e o Centro dos Lavradores do Estado de São Paulo, entidade fundada em 1899, e que funcionava como comissão executiva do Partido da Lavoura.

\subsection{Pela Lavoura: a disputa pelas associações de fazendeiros}

A crise fizera com que as dissensões no interior do poder oligárquico tomassem um novo sentido; a partir de 1896, a oposição e as dissidências passaram a se articular em torno da crítica à condução da política econômica conduzida pelo PRP no âmbito da crise cafeeira. Na evolução desse processo, os diversos movimentos de contestação do status quo tomaram para si os reclamos dos fazendeiros em prol dos auxílios à lavoura, ao mesmo tempo, a insatisfação generalizada dava aos defensores do regresso monarquista o combustível para inflamar a "lavoura" contra a República. Desse modo, enquanto a dinâmica dos conflitos anteriores a 1896 estavam relacionados às disputas pela sucessão presidencial e tinham no jacobinismo o principal agente aglutinador da oposição oligárquica no Estado, depois de 1896, a questão dos auxílios à lavoura e a problemática da crise passariam a articular as forças que resistiam ao controle exercido pela direção do PRP.

Como bem destacou Casalecchi, depois de 1896, o partido e o governo passam a sofrer ponderável desgaste em suas hostes, com a crise, caberia ao governo enfrentar, ao mesmo tempo, dois novos problemas: o do complexo agroexportador cafeeiro e o da bancarrota financeira do estado ${ }^{184}$. Renato Perissinotto destacou que durante a crise a insatisfação dos fazendeiros com a política econômica cresceu a ponto de colocar em risco a hegemonia local do Partido Republicano Paulista, em um momento em que se consolidava no controle do governo da República ${ }^{185}$. Nesse mesmo sentido, José Ênio Casalecchi afirmara que nunca os paulistas tiveram tamanho controle sobre o governo federal - entre 1894 e 1906, porém, até aquele momento o PRP não conhecera oposição tão forte dentro do seu próprio estado.

${ }^{184}$ CASALECCHI, 1987, op. cit., p. 88

185 Sobre a reação dos fazendeiros às políticas econômicas dos governos paulista e federal durante a Primeira República, veja SAES, 1986, op. cit., pp. 172-180; PERISSINOTO, 1994, op. cit., pp. 17-45 e TORELLI, L. S., A Defesa do Café e a Política Cambial: Os Interesses da Elite Paulista na Primeira República (1898-1920), Campinas, IE/Unicamp, 2004. 
A crise política ocasionada pelo descontentamento com a política econômica nos permite desmitificar o domínio que se atribuiu à direção do PRP sobre o processo político do estado, mostrando que a hegemonia exercida por esse grupo era contestada frequentemente e não fora conquistada sem grandes dificuldades. $\mathrm{O}$ descontentamento por pouco não ocasionou um grave racha no partido, com dirigentes aderindo à tentativa de criação do Partido da Lavoura.

Diante da ameaça a seu partido, o governo tentou dissuadir dissidentes e oposicionistas com um processo não linear de negociações, que incluía a cooptação de lideranças e a aprovação de leis que contemplavam as reivindicações da lavoura, mas que muitas vezes não chegavam a ser cumpridas.

Enquanto muitos fazendeiros cobravam do Estado a concessão dos chamados auxílio à lavoura, fazendeiros mais afinados com a política oficial, refratária às intervenções do poder político no espaço econômico, afirmavam que os próprios fazendeiros deveriam encontrar saídas para superar suas dificuldades financeiras. Uma das formas indicadas era a criação de associações de classe, conforme o exemplo dos agricultores franceses que, diante da crise enfrentada nas últimas décadas, organizaram formas independentes de financiar a modernização dos processos de cultivo em vez de reivindicar o socorro estatal ${ }^{186}$. Esse discurso refletia a tendência do movimento agrícola francês ao criar associações agrícolas com objetivo de propagar novas técnicas de cultivo, adquirindo no atacado adubos e implementos para uso de seus sócios, além de estabelecerem novos canais de comercialização e organizarem caixas cooperativas de crédito.

Entretanto, as sociedades agrícolas criadas em São Paulo acabaram se transformando em espaços de contestação da política econômica e, o que era ainda mais grave, possibilitavam a criação de espaços de representatividade que concorriam com o partido oficial e pressionavam o governo no sentido de intervir no mercado de crédito, trabalho e na comercialização do café. Temendo que associações de fazendeiros pudessem tomar rumo político, os poderes constituídos se esforçaram para que o próprio Estado agregasse tais associações à sua estrutura administrativa, domando o ímpeto contestatório, o que foi conseguido com a criação do Serviço Agronômico do Estado de

${ }^{186}$ SAES, 1986, op. cit., p. 177. 
São Paulo, em 1900, e a tutela exercida sobre a Sociedade Paulista de Agricultura, criada em 1902.

\subsubsection{A Associação dos Lavradores Paulistas de 1896}

Na década de 1880, houve um intenso movimento de formação de associações locais que congregavam os interesses de proprietários escravistas. Tratavam-se dos clubes da lavoura que surgiram em diversos pontos do império e que, na província de São Paulo, teve como principal representante o Clube da Lavoura de Campinas. O clube ofereceu duro combate aos abolicionistas e logrou derrubar a lei provincial de 1881 que taxava as transações de escravos na província ${ }^{187}$. Na mesma época, foi organizado no Rio de Janeiro o Centro da Lavoura e do Comércio que se propunha a funcionar como ponto de articulação dos diversos clubes que vinham surgindo no território do império. O Centro da Lavoura, segundo Marieta de Moraes Ferreira, havia se constituído em um importante centro de combate ao abolicionismo em torno do qual estavam articulados os interesses do comissariado fluminense, cuja maior realização foi a aprovação da "lei das execuções civis e comerciais" de $1885^{188}$. Após a abolição e o advento da República, os clubes da lavoura desapareceram em São Paulo.

Em 1893, Manoel Ferraz de Campos Salles, que havia participado do Clube da Lavoura de Campinas e agora ocupava o cargo de senador da República pelo Partido Republicano Paulista, fizera uma viagem à Europa e teve oportunidade de conhecer as realizações da Société des Agriculteurs de France, uma entidade que funcionava como sindicato central de agricultores. Em carta remetida à imprensa e publicada no Correio Paulistano, Campos Salles propunha a adaptação da experiência francesa às necessidades dos agricultores paulistas, aproveitando-se da experiência ainda recente dos clubes da lavoura, os quais ele acreditava que foram malsucedidos no intuito de congregar os interesses da classe agrícola devido aos antagonismos em torno do trabalho escravo.

\footnotetext{
${ }^{187}$ A Lei provincial n. 1, de 21 de janeiro de 1881, estipulava uma taxa de 2:000\$000 sobre a averbação de escravos e destinava-se a formar um fundo para o financiamento da imigração que, por meio da Lei n. 36, de 21 de fevereiro de 1881, permitia a aplicação de até 150:000\$000 para o pagamento de passagens a imigrantes e na construção de uma hospedaria. Em torno desse debate havia se colocado o interesse de fazendeiros das regiões mais antigas do oeste paulista, defensores do escravismo, contra o daqueles que investiam nas novas zonas e que apoiavam a mudança no regime de trabalho e a subvenção da imigração, como era o caso do deputado republicano à assembleia provincial, Martinho Prado Jr., autor da referida lei. Cf. BEIGUELMAN, Paula. A formação do povo no complexo cafeeiro: aspectos políticos, São Paulo: EDUSP, 2005, p. 64.

${ }^{188}$ CF. FERREIRA, 1977, op. cit.
} 
Dizia o senador Campos Salles que:

A existência da escravidão criava antagonismos irreconciliáveis nos interesses e nos intuitos dos próprios agricultores, que embaraçavam a ação coletiva, impedindo a coesão dos sentimentos e quebrando os laços de solidariedade. E para dizer tudo, o egoísmo de interesse individual, produto fatal da malfadada instituição, tinha aniquilado o espírito de classe. Agora, porém, que a causa desapareceu e que a coordenação dos interesses abre franco espaço para ao sentimento de concórdia, precioso apanágio dos paulistas, parece que seria tempo de cogitar destes magnos interesses ${ }^{189}$.

Em maio de 1896, Campos Salles assumiu a presidência do estado de São Paulo e decidiu fomentar a criação de uma associação de lavradores que deveria celebrar o abiente de concórdia em que vivia a classe agrícola paulista. Ele nomeu uma comissão provisória composta por importantes fazendeiros e a encarregou de convocar delegados nas mais diversas localidade do estado para realização de um congresso agrícola para constituição da Sociedade dos Agricultores Paulista. Essa comissão era composta por Jorge Miranda, Rodolfo Miranda, Cerqueira Cesar, Antonio da Silva Prado, Jorge Tibiriçá, Rodolfo Dantas, Domingos de Moraes Salles e Francisco de Paula Queiroz. Uma vez que fosse concluída a organização da sociedade, os delegados presentes em sua assembleia deveriam retornar a seus municípios imbuídos do propósito de reunir os fazendeiros da localidade e criar sociedades locais que se filiariam àquela sociedade central $^{190}$.

Naquela altura, entretanto, havia uma crise rondando a lavoura cafeeira. Diante dos prognósticos de queda nos preços, os comissários haviam suspendido os adiantamentos, levando os fazendeiros a se indisporem com comissários, banqueiros e capitalistas. Em vez de concórdia, Campos Salles vira os preparativos para a assembleia da associação sofrerem a influência da escalada das tensões que emergiam nas diversas localidade do estado. Os fazendeiros estavam exaltados contra o sistema de crédito e exigiam do governo republicano que interviesse no sistema de crédito, proibisse as companhias ferroviárias de elevar as tarifas de acordo com o movimento do câmbio e que aprovasse leis que lhes permitissem coagir os colonos a aceitarem a diminuição dos salários.

${ }^{189}$ Correio Paulistano, 15/3/1893. "Carta de Paris", p.1.

${ }^{190}$ Cf. CASALECCHI, 1987, op. cit., pp.88-9; O Commercio de São Paulo, 2/9/1896. "Congresso dos Lavradores Paulista"; Revista Industrial de Minas Gerais, n. 18-19, p. (?) 
Entre o final de julho e início de agosto de 1896, enquanto se realizavam reuniões de lavradores nas localidades para a escolha dos delegados ao congresso agrícola que se reuniria na capital, o clima de tensão havia contaminado os preparativos para criação da Sociedade dos Agricultores ${ }^{191}$. Por intermédio da comissão provisória, o governo buscou adiar a realização do congresso e após dois adiamentos, foi criada uma comissão paralela que convocou um congresso de lavradores que se reunião em $1^{\circ}$ de setembro na sede do Banco Construtor, na Capital paulista ${ }^{192}$. A pauta desse congresso previa a escolha de um presidente que deveria se entender com a comissão provisória a fim de concluir a organização da Sociedade dos Agricultores e nomear diversas comissões para estudar os assuntos de seu interesse, entre os quais se destacavam a questão do trabalho e o crédito agrícola $^{193}$. No mesmo dia em que se reunira o congresso de lavradores, a comissão provisória se reuniu e marcou para o próximo dia 30 de setembro a realização do congresso para instalação da Sociedade dos Agricultores Paulistas.

No dia do congresso, um editorial do jornal monarquista $O$ Comércio de São Paulo demonstrava que aquela reunião de fazendeiros deveria se transformar em um espaço de contestação do governo republicano, como dizia o editorial, "a reunião de hoje é um verdadeiro meeting contra a administração republicana”. Ele aproveitou a ocasião para fazer propaganda monarquista, ao afirmar que fora graças à monarquia que a lavoura expandira-se em São Paulo, pela constituição das estradas de ferro, do serviço de imigração e, principalmente, as facilidades do crédito transformadas pela República em orgia. O editorial terminava conclamando os fazendeiros a intervirem na política do Estado, o que significava o lançamento de candidaturas em oposição ao PRP ${ }^{194}$.

O congresso se reuniu na sede da Secretaria de Agricultura e contou com a participação de 150 delegados. A sessão de abertura foi iniciada por Antonio da Silva Prado que convidou para presidir os trabalhos o secretário de agricultura, Alvaro de

${ }^{191}$ No que dizia respeito ao crédito, os fazendeiros defendiam a criação de um banco agrícola estadual, composto por agências nos municípios, as quais se encarregariam da abertura de contas correntes aos fazendeiros, tais operações deveriam ser realizadas sob a garantia do penhor agrícola. Nessa proposta, observa-se o intuito de modificar o sistema de crédito, levando até as sedes de município as filiais de instituições bancárias que deveriam substituir os comissários no fornecimento de adiantamentos sob garantia das safras. Cf. Correio Paulistano, 22/ 7 e 7/8 de 1896.

192 Correio Paulistano, 23/9/1896.

${ }^{193}$ No que se refere ao trabalho, os fazendeiros reunidos nesse congresso, defendiam a descentralização do serviço de imigração, com a criação de hospedaria locais de imigrantes e de um serviço de colocação de trabalhadores; além da introdução de imigrantes alemães, em caráter permanente, e de japoneses, em caráter transitório; e, por fim, a organização de núcleos de pequenos proprietários imigrantes que servissem de viveiros de trabalho sazonal. Cf. Correio Paulistano, 02.09.1896.

${ }^{194}$ O Commercio de São Paulo, 30/9/1896, "Aflicções da lavoura". 
Carvalho. Em seguida, foi eleita a diretoria da Sociedade dos Agricultores, composta por Antonio Prado, Conde do Pinhal, Antonio Luiz dos Santos Werneck, Jorge Miranda, Luiz Pereira Barreto, Barão Geraldo Rezende, José Paulino Nogueira, Rodolpho Miranda e Luiz Piza ${ }^{195}$. Em seguida, iniciou-se a discussão dos estatutos da sociedade. Embora a pauta se restringisse à instalação daquela associação, as conferências giraram em torno de temas como a força de trabalho e o crédito agrícola.

No que diz respeito especificamente ao crédito, fora proposto a garantia estatal das letras hipotecárias, criação de um banco estadual com filiais nos municípios e curso forçado para as letras hipotecárias. O incentivo à criação de bancos municipais, proposto por Luiz Carlos de Assumpção, estava baseado na organização das cooperativas de crédito europeias e tinha muitas das características dos Bancos de Custeio Rural que discutiremos adiante. Tendo caráter mutual esse banco deveria ser constituído por assembleia de lavradores do município e suas transações deveriam ser limitadas aos adiantamentos mensais realizados apenas aos fazendeiros associados. Além das funções de financiamento, esse banco deveria também ser encarregado de organizar a comercialização da produção de seus sócios, substituindo, dessa forma, o comissário de café ${ }^{196}$.

Foi na sessão de encerramento desse congresso que Antonio Prado proferiu o célebre discurso sobre as causas da crise que causou descontentamento de muitos fazendeiros e foi reproduzido pelo Jornal do Comércio. Enquanto a maioria dos lavradores reivindicavam auxílios do governo paulista à lavoura, Prado os aconselhava a reduzir seus investimentos ao alcance de seus braços e responsabilizou os fazendeiros pelo descuido com a lavoura, condenou-os por aumentarem demasiadamente suas plantações e de se mudarem para a cidade, abrindo mão da administração de suas fazendas em detrimento de administradores ineptos e os aconselhava a educarem os seus filhos de maneira a incutir-lhes o amor pela terra. Apesar de falar como contido fazendeiro, o próprio Antônio Prado era também um capitalista, atuava como prestamista, era diretor de banco, firma comissátria e companhia de estrada de ferro, além de fabulosas inversões em fazendas pelo interior do estado. Na verdade, como afirmou Flávio Saes, ele falava

195 O Commercio de São Paulo, 1/10/1896, "Congresso Agricola”.

${ }^{196}$ Correio Paulistano, 3/10/1896. 
como fazendeiro a fazendeiros, mas o seu discurso refletia interesses urbanos, como comissário, capitalista e diretor de banco que era ${ }^{197}$.

Por outro lado, ele pedia aos fazendeiros que não se alarmassem, pois não havia uma verdadeira crise da lavoura cafeeira, pois o que ocorrera fora unicamente uma crise financeira, passageira. Como resposta às queixas dos fazendeiros a respeito da restrição de crédito do comércio comissário durante a crise, Antonio Prado afirmava que aquilo ocorrera por conta da crise financeira que atingira também os bancos e os comissários. Dizia ele que os banqueiros e comissários, embora tenham toda a confiança na classe agrícola, viram-se na dura necessidade de restringir os adiantamentos ${ }^{198}$.

O relatório do secretario de agricultura apontava uma interpretação idêntica à de Antonio Prado. Ao mesmo tempo em que refutava o caráter econômico da crise, afirmava que seria no seu próprio bojo que a lavoura encontraria o remédio para suas dificuldades, pois, a diminuição dos preços causaria alargamento do consumo e redução dos investimentos, possibilitando o equilíbrio da produção. O problema do trabalho também seria resolvido naturalmente como resultado da crise, pois, se fosse mantida a oferta de braços, o seu excesso deveria saturar a lavoura, contribuindo para redução dos salários sem recorrer à coerção dos trabalhadores. No que dizia respeito à redução das tarifas ferroviárias, o secretário lembrava que tal medida não podia ser tomada pelo governo porque ela punha em choque duas classes, a dos lavradores e a dos acionistas das estradas de ferro ${ }^{199}$.

Posteriormente, a Sociedade dos Agricultores Paulistas desapareceu dos jornais e, de acordo com José Ênio Casalecchi, o governo paulista, temendo que a sociedade tomasse rumo político resolveu desmobilizá-1a ${ }^{200}$. Uma matéria publicada em um jornal paulistano em 1898 indicava que ela havia desaparecido ainda em 1896 ${ }^{201}$. Em sua mensagem anual, Campos Salles não fez qualquer menção à realização do congresso ou da constituição da sociedade, mas fez ameaça contra a manifestação de monarquistas ${ }^{202}$.

\footnotetext{
${ }^{197}$ SAES, 1986, op. cit., p. 177

${ }^{198}$ Correio Paulistano, 5/10/1896. "Congresso Agricola, $3^{\text {a }}$ Sessão ordinaria".

199 SÃO PAULO. SECRETARIA DA AGRICULTURA. Relatório de 1896 apresentado ao Dr. Manoel Ferraz de Campos Salles, presidente do estado, pelo Dr. Alvaro Augusto da Costa Carvalho, Secretário dos Negócios da Agricultura, Commercio e Obras Públicas. São Paulo Espindola, Siqueira 1897, p. 80.

${ }^{200}$ CASALECCHI, 1987, op. cit., p. 89.

201 O Commercio de São Paulo, 18/8/1898, p. 1.

202 SAO PAULO. Mensagem enviada ao Congresso Legislativo a 7 de abril de 1897 por Campos Salles Presidente do Estado, São Paulo, Typ. do Diario Official 1897.
} 


\subsubsection{Os clubes da lavoura e a constituição do Partido da Lavoura}

Em 1899, o descontentamento da lavoura com a atução dos governos estadual e federal misturava-se às disputas em torno do controle da política estadual e contribuía para o recrudencimento dos conflitos. Desde 1896, o governo paulista havia endurecido com a oposição ao PRP, fechando o Centro Monarquista e proibindo manifestações de cunho restaurador, abortando as tentativas de constituição de um partido monarquista, além de dissuadir a formação de dissidências dentro do Partido Republicano Paulista. Nessa altura, as manifestações de caráter dissidente assim como as restauradoras passariam a se agrupar em torno da proposta de criação do Partido da Lavoura, agremiação que relacionada ao contexto da crise, reivindicava o apoio dos fazendeiros mais prejudicados em contraposição ao núcleo dirigente do PRP no controle dos governos estadual e federal.

Esse partido agrupava, portanto, republicanos dissidentes, jacobinos e monarquistas. Diante da coerção realizada pelo governo paulista, a sua organização passara a ser ocultada pela mobilização para criação de clubes da lavoura. Essas associações locais de lavradores estariam distribuídas pelas diversas localidades do interior e formariam uma entidade central, denominada Centro dos Lavradores do Estado de São Paulo.

A criação dos clubes da lavoura remontava aos vários clubes homônimos que surgiram no interior do estado na década de 1880 e que reuniam fazendeiros das zonas de produção mais antiga do "oeste paulista" em oposição aos interesses imigrantistas e abolicionistas de fazendeiros das zonas mais novas. Nessa nova leva, os clubes da lavoura deveriam agrupar os fazendeiros descontentes com a política agrícola do PRP e teve no Clube da Lavoura de São Carlos o seu precursor, fundado em 6 de janeiro de 1899, sob a direção de Raphael de Abreu Sampaio Vidal ${ }^{203}$.

Oficialmente os clubes da lavoura deveriam funcionar como sindicatos agrícolas, promovendo a popularização de modernas práticas agrícolas, confecção de estatísticas da produção, além de contribuir para a organização de caixas de crédito. Na prática, eles acabaram funcionando como diretórios municipais do Partido da Lavoura, enquanto o Centro dos Lavradores deveria funcionar como o seu diretório central. Esse tipo de

\footnotetext{
${ }^{203}$ Sócio em importante firma comissária de Santos e foi diretor do Banco União de São Carlos, fundado por Antonio Carlos de Arruda Botelho, o Conde do Pinhal.
} 
sociedade guardava semelhanças com o Centro Católico Alemão, entidade central das associações locais de proprietarios que nas localidades organizavam cooperativas e caixas de crédito e que, em âmbito nacional, atuava como um partido, elegendo representantes para o parlamento.

Em fevereiro de 1899, estavam em funcionamento os clubes da lavoura de São Carlos do Pinhal, Brotas, Araraquara, Batatais, São Simão, Santa Cruz das Palmeiras, Campinas, Franca, São José do Rio Pardo, Jaboticabal e Ribeirão Preto ${ }^{204}$. Na cobertura realizada pela imprensa paulista a respeito das reuniões para constituição dos clubes, as lideranças locais se preocupavam em refutar o seu caráter político, como pode ser observado nas reuniões de São Carlos do Pinhal e Araraquara: nesta última cidade uma nota do clube local afirmava que não se trata de uma organização política partidária, nem da escolha de candidatos ao Congresso nem da designação de pretendentes a empregos públicos ${ }^{205}$.

Em 23 de janeiro, o monarquista Antonio Cândido Rodrigues convocava os fazendeiros de São José do Rio Pardo para fundação do clube local ${ }^{206}$ e, em 23 de fevereiro, outro conhecido monarquista, Eduardo Prado, convidava os fazendeiros de Santa Cruz das Palmeiras, para a reunião para discutir a fundação do clube local ${ }^{207}$. Enquanto isso, o clube de Batatais era republicano, presidido por Washington Luiz, que, havia convocado a reunião para a organização do clube de Ribeirão Preto. O clube de Batatais era republicano dissidente e o de São Carlos, monarquista, em outras localidades, entretanto, as duas tendências estavam presentes na organização, como era o caso de Jaboticabal, em que os lavradores eram chamados a superar suas dissensões políticas em prol do interesse de classe ${ }^{208}$ e, em Franca, onde um periódico publicou a lista dos participantes ressaltando que compareceram membros de todos os partidos políticos, ficando, portanto dissipadas as suspeitas de que ali se pretendia fazer política ${ }^{209}$. Em outras cidades, o caráter político dos clubes era defendido abertamente, como era o caso de Brotas, na reunião convocada pelo juiz de direito, José Pedro dizia-se que $o$ Club muito

${ }^{204}$ O Commercio de São Paulo, 6/3/1899, p. 1 - "O movimento agricola”; Correio da Manhã, 2/3/1899, p. 2, "Convite aos senhores lavradores de Santa Cruz das Palmeiras" e Correio da Manhã, 16/9/1899, "Club da Lavoura de Jaboticabal".

205 O Commercio de São Paulo, 8/3/1899, p. 1 - "Movimento agricola".

${ }^{206}$ Correio da Manhã, 2/2/1899 - "S. José do Rio Pardo, Reunião de Lavradores".

207 Correio da Manhã, 2/3/1899, p. 2 - "Convite aos senhores lavradores de Santa Cruz das Palmeiras"

${ }^{208}$ Correio da Manhã, 16/9/1899 - Club da Lavoura de Jaboticabal.

${ }^{209}$ Correio Paulistano, 17/3/1899, p. 2 - "Franca, Reunião da Lavoura". 
precisa de um caráter político para poder intervir na administração pública por meio de seus legítimos representantes ${ }^{210}$.

Reuniões similares estavam sendo realizadas em Minas Gerais, com a fundação de clubes em cidades como Jacutinga e Uberaba, e reunira-se na cidade de Juiz de Fora, em 15 de novembro, a assembleia de fundação do Centro da Lavoura e Indústria de Minas Gerais, que teria objetivos idênticos aos de São Paulo, organizar clubes locais de fazendeiros, filiados ao Centro que indicaria seus candidatos aos pleitos do Estado ${ }^{211}$. Enquanto isso, Augusto Silva Telles afirmava em artigo publicado no $O$ Estado de São Paulo que as assembleias dos clubes serviam de tribuna para expansões exclusivamente partidárias, explorando-se o mal estar da lavoura; em breve veremos a propaganda do café degenerando em propaganda política ${ }^{212}$.

Em março de 1899, os diversos clubes espalhados pelo estado elegeram delegados para um congresso em Campinas para fundação do Centro da Lavoura do Estado de São Paulo, com sede naquela cidade e que deveria congregar todos os clubes do estado. Seus estatutos afirmavam que o Centro tinha por objetivo: manter a opinião da classe, defender a redução de impostos, a expansão do crédito real e a criação de bancos agrícolas, redução das tarifas das estradas de ferro, manutenção do serviço imigratório e a criação de núcleos agrícolas para produção de cereais; além disso, ele se propunha a organizar estatísticas da produção agrícola no município, exposições periódicas de produtos agrícolas e pastoris, escolas práticas de agricultura, bancos regionais que recebessem pequenas quantias em depósito, promover o estudo das condições da cultura de café nos países estrangeiros e dos mercados consumidores e defender a aprovação de leis que regulassem as relações entre os proprietários e os trabalhadores ${ }^{213}$.

Em 28 de setembro, o Jornal do Comércio publicou a introdução do relatório do ministro da Fazenda Joaquim Murtinho que dizia que a crise da cafeicultura seria resolvida pela seleção natural, em uma luta em que apenas os produtores mais fortes e preparados sobreviveriam. A publicação desse relatório provocou manifestações acaloradas contra o ministro, com a assembleia do Clube da Lavoura de Boa Esperança,

\footnotetext{
${ }^{210}$ Correio Paulistano, 22/1/1899, p. 1.

211 Cf. Correio Paulistano, 20/11/1899, p. 2 - "Centro da Lavoura e Industria de Minas Gerais"; O Commercio de São Paulo, 11/3/1899, p. 1 - "Movimento agricola".

212 TELLES, Augusto C. da Silva. O café e o Estado de S. Paulo. São Paulo, Diario Official, 1900, p. 19.

${ }^{213}$ No Congresso realizado em 25 de março de 1899, a mesa do congresso havia sido presidida por Inglez de Souza, Barão de Ataliba e Rodrigo Lobato Marcondes Machado. Veja Correio Paulistano, 26/3/1899, p. 1 - "O Congresso de Campinas".
} 
reunida em 13 de outubro e que afirmava ser preciso que a lavoura se ponha francamente em campo, em sua própria defesa, sem mais hesitações e receios, a fim de evitar que prevaleçam as teorias do Sr. Murtinho ${ }^{214}$. Enquanto isso, o Barão do Rio Pardo, presidente do Clube de Casa Branca oficiou ao Centro dos Lavradores a necessidade de ele assumir um papel francamente político, intervindo nas próximas eleições:

Este clube, colocando-se na vanguarda da ideia da intervenção política, foi impelido, além de muitos outros motivos, pela recente e monstruosa heresia atirada ineptamente e audaciosamente à face de toda a nação pelo seu tresloucado ministro das finanças, aconselhando-nos, como único meio de salvação, ou devorarmo-nos mutuamente, como canibais ${ }^{215}$.

Com o avanço das propostas de candidaturas do Partido da Lavoura apoiadas pelos clubes da lavoura, o jornal $O$ Estado de São Paulo buscou dissuadir os dissidentes refutando a tese de que "a lavoura" era uma classe desprestigiada e argumentando a cisão classista abriria um perigoso precedente para a criação de um partido operário, que prejudicaria a classe da lavoura como um todo. De acordo com a opinião expressa nesse jornal, não fazia sentido dizer que a lavoura era desprestigiada quando as lideranças políticas no comando das localidades e do próprio Estado eram também lavradores:

Ide a mais modesta vila do Estado e perguntai quem é o chefe político. Um lavrador. O Juiz de Paz é lavrador, os vereadores são lavradores e, se não o são, obedecem respeitosamente ao mando do fazendeiro rico que, queira ou não queira, governa a localidade. No Congresso Legislativo a maioria é de lavradores e na administração superior do Estado também. O secretário da agricultura é quase sempre um lavrador. Subi um pouco mais: quem é o presidente da República? O nosso patrício Dr. Campos Salles, um lavrador ${ }^{216}$.

Nesse momento a criação do Partido da Lavoura contava com o apoio de dois importantes jornais paulistas, o monarquista O Comércio de São Paulo e Correio Paulistano, que funcionava anteriormente como órgão oficial do PRP, mas que nesse momento apoiava a dissidência republicana. Em resposta aos artigos publicados no $O$ Estado de São Paulo, no Correio Paulistano 2 publicava-se a seguinte opinião:

Se a lavoura paulista organizar um partido político e se este for vencedor, que mal haverá nisso? Pois já se não revezaram no poder três partidos - o governista, o amerista [Américo Brasiliense] e o federal [Francisco Glicério] - estando agora nele o republicano e sem que por isso viesse abaixo o céu velho, cuja incomensurável abóbada cobre tantas perfídias e tantas ambições?

\footnotetext{
${ }^{214}$ O Commercio de São Paulo, 23/10/1899, p. 1 - "Movimento agrícola".

${ }^{215}$ O Commercio de São Paulo, 18/10/1899, p. 1 - "Movimento agrícola".

${ }^{216}$ CASALECCHI, p. 97.
} 
Enquanto o Centro da Lavoura não manifestava uma posição oficial a respeito das próximas eleições, diversos clubes faziam suas indicações de candidatos da lavoura. Assim, o clube de Casa Branca anunciou o Sr. Conselheiro Antonio Prado, para a presidência, não da república, mas simplesmente do Estado; o senhor Adolpho Botelho, para vice-presidente, e os senhores Eduardo Prado e Washington [Luis Pereira] de Souza, para deputados federais ${ }^{217}$, enquanto o clube de Franca indicava Antonio Prado e Adolpho Botelho para presidente e vice; Francisco Glycério e Washington Luis para deputados e Manoel de Moraes Barros para o senado ${ }^{218}$, esta mesma chapa foi também indicada pelos clubes de Santa Rita do Paraiso e Batatais ${ }^{219}$.

Antonio Prado contava com respeito de monarquistas e republicanos; apesar de nunca ter aderido ao Partido Republicano, ele havia dado importante apoio à República ao dissuadir outros monarquistas da tentativa de criação de um partido de oposição em 1893, o Partido Republicano Conservador. Eduardo Prado era monarquista e ferrenho opositor da República e, Francisco Glicério, jacobino, fez oposição aos republicanos históricos desde a proclamação da República. Enquanto isso, Manoel de Moraes Barros era senador da República e irmão de Prudente de Moraes, já Washington Luiz era republicano dissidente, adversário tanto dos monarquistas como dos jacobinos e da direção do PRP.

Um colunista do Jornal do Comércio fazia críticas às indicações de candidatos feitas pelos clubes da lavoura, na opinião desse colunista, Antonio Prado não tinha muitas simpatias na classe dos lavradores devido aos conceitos que sobre estes formulou na reunião convocada, há tempos, nesta capital pelo secretário de Agricultura. Ele defendia que as indicações de candidatos fossem feitas pelo Centro dos Lavradores, para evitar a dispersão, além de criticar as indicações de Francisco Glycerio que, além de não ser fazendeiro, ninguém podia ignorar que era jacobino e nesta condição, eleito presidente, será o coveiro da lavoura 220.

Em 22 de outubro, o Congresso Agrícola reunia-se na cidade de Campinas para deliberar sobre os candidatos da lavoura, em que o delegado de Casa Branca afirmava que não militando aquele clube sob qualquer bandeira política o seu partido compor-seá de monarquistas, republicanos conservadores, ou jacobinos e, bem assim, dos

\footnotetext{
217 O Commercio de São Paulo, 6/11/1899, p. 1 - "Rabiscos".

${ }^{218}$ O Commercio de São Paulo, 6/11/1899, p. 1 - "Rabiscos".

${ }^{219}$ O Commercio de São Paulo, 17/11/1899, p. 1.

${ }^{220}$ O Commercio de São Paulo, 7/11/1899, p. 1 - "Movimento agricola".
} 
indiferentes $^{221}$. O congresso do Centro da Lavoura acabou por indicar apenas candidatos para as eleições legislativas que ocorreriam em 31 de dezembro, sendo escolhidos Francisco Glicério e Washington Luiz para concorrerem pelo $6^{\circ}$ distrito eleitoral, estes obtiveram maioria dos votos em diversos municípios, mas não se elegeram.

Após as eleições parlamentares, a concretização do Centro da Lavoura e o sucesso da articulação de candidaturas próprias que rompeu a barreira oferecida pela máquina partidária do PRP, o governo modificou o modo de conduzir a crise política e a crise cafeeira. Aparentemente houve um acordo que envolveu as lideranças do Centro da Lavoura e a direção do PRP: em 15 de janeiro, o Centro se reuniu novamente e decidiu abrir mão de lançar candidaturas ao executivo estadual:

Após a nossa recente e valorosa vitória nas urnas [...] mister seria que também pressurosos corrêssemos às urnas na eleição presidencial, afim de sufragarmos um nome distinto e digno de ocupar o primeiro lugar na magistratura do Estado. Entretanto, interesses de ordem maior, circunstancias imperiosas de muito alcance e resultados, determinaram que abstenhamo-nos desse pleito, donde por certo, sairão triunfantes os já escolhidos e designados pelo atual governo.

Estava em andamento o processo de pacificação do Partido Republicano que levou ao abandono do Partido da Lavoura por parte do Centro da Lavoura, o que levaria também ao esvaziamento deste último, assim como ao enfraquecimento das aspirações restauradoras e culminaria na eleição de Rodrigues Alves à presidência do Estado e a um secretariado composto por lideranças do Centro da Lavoura, como a escolha de Cândido Rodrigues para a Secretaria da Agricultura e a criação do Serviço Agronômico do Estado de São Paulo, uma instância estatal que passaria a cumprir o papel pretendido pelo Centro da Lavoura.

O Serviço Agronômico do Estado de São Paulo começou a funcionar em 1900 e tinha sua sede na cidade de Campinas e assumiria, praticamente, todas as atribuições planejadas para o Centro da Lavoura, tais como a promoção do ensino agrícola, organização de estatísticas da produção agropecuária, além de pesquisa e fomento de novas práticas de cultivo. Mas o principal ponto de convergência era o papel que este órgão passaria a ocupar na articulação das comissões municipais de agricultura, constituídas como instâncias semiautônomas para discussão dos interesses dos fazendeiros locais.

${ }^{221}$ O Commercio de São Paulo, 7/11/1899, p. 1 - "Ao eleitorado do $1^{\circ}$ districto e especialmente ao da comarca de Casa Branca". 
As comissões municipais eram compostas por três fazendeiros residentes no município e tinham a incumbência de representar os interesses dos fazendeiros de sua localidade no governo, responder às solicitações de informações feitas pela Secretaria de Agricultura, tais como dados da produção agrícola para confecção de estatísticas e convocar e presidir as reuniões dos lavradores do município ${ }^{222}$.

Com a criação do Serviço Agronômico, o governo estadual resolvia diversas carências apontadas durante a crise como a falta de estatísticas da produção agrícola e a promoção de novos métodos de criação e cultivo. A primeira estatística geral da produção agrícola do estado foi executada pelo órgão em 1904. Ele também passou a gerir as escolas práticas de agricultura e o registro climatológico. Por outro lado, por meio das comissões municipais, o Serviço Agronômico trazia para dentro da estrutura da Secretaria de Agricultura as discussões de aspectos relevantes aos fazendeiros locais, contribuindo para esvaziar os clubes da lavoura, afastando-se a influência de forças dissidentes e a propaganda monarquista.

\subsubsection{A constituição da Sociedade Paulista de Agricultura e o papel das comissões municipais de agricultura em 1902}

Em fevereiro de 1902 foi organizada a Sociedade Paulista de Agricultura. Desde a fracassada tentativava de organização da Sociedade dos Agricultores Paulistas, patrocinada por Campos Salles, o governo paulista logrou impedir a constituição de sociedades agrícolas, dado o risco de que elas se transformassem em organizações de caráter político que concorressem ou pudessem pressionar a Comissão Central do Partido Republicano Paulista ${ }^{223}$. A criação de uma sociedade de agricultura foi possível apenas em 1902 devido à conciliação entre o governo e as forças dissidentes que ameaçavam a hegemonia do PRP. A SPA se constituirá, assim, em uma entidade semioficial, dirigida pelos grandes fazendeiros de café de São Paulo e subsidiada pelo governo paulista.

O percurso para a criação dessa entidade teve início em 1899, quando, paralelamente à criação do Centro da Lavoura do Estado de São Paulo, foi organizado no Rio de Janeiro, o Centro dos Lavradores do Brasil, uma sociedade de caráter privado,

\footnotetext{
${ }^{222}$ A lei n. 678, de 13 de setembro de 1899, que criava o serviço agronômico também instituía as Comissões Municipais de Agricultura, regulamentadas pelo decreto n. 752, de 15 de março de 1900.

223 SÃO PAULO. SECRETARIA DA AGRICULTURA. Relatório de 1896 apresentado ao Dr. Manoel Ferraz de Campos Salles, presidente do estado, pelo Dr. Alvaro Augusto da Costa Carvalho, Secretário dos Negócios da Agricultura, Commercio e Obras Públicas. São Paulo Espindola, Siqueira 1897.
} 
ligada à Sociedade Nacional de Agricultura, mas subsidiada pelos governos da União em conjunto com os principais estados produtores de café224. Em novembro de 1899, a SNA nomeou uma comissão de grandes fazendeiros residentes na capital paulista para discutir a propaganda a cargo do Centro da Lavoura. A SNA pretendia criar uma instância estadual para tratar do assunto que fosse composta por delegados indicados pelos fazendeiros nas localidades, que possivelmente devesse se transformar em uma sociedade estadual. Essa instância, composta por representantes das localidades, estaria submetida a uma segunda, composta por fazendeiros paulistas com cargo no Congresso Nacional mais o conselheiro Leôncio de Carvalho, que já ocupava a função de comissário do governo paulista na capital federal. Observa-se assim o objetivo de se manter a legitimidade do processo e ao mesmo tempo mantê-la submetida ao PRP 225 .

Pouco mais de 12 meses depois, Leôncio de Carvalho concvocara uma reunião de lavradores que se reuniram na sede da Secretaria de Agricultura para organizar uma associação agrícola e comercial para defesa dos interesses ligados ao café. A Sociedade Paulista de Agricultura foi formamalemnte constituída em 23 de fevereiro daquele e ano e sua diretoria era composta por Luiz Pereira Barreto (presidente), Leôncio de Carvalho (secretário), além de José Paulino Nogueira, Augusto da Silva Telles, Carlos Botelho, Siqueira Campos, Raul Rezende e Fernando Werneck ${ }^{226}$.

Segundo o jornal O Comércio de São Paulo, a primeira reunião para constituição da sociedade, realizada em 8 de fevereiro, havia traçado que seus objetivos seriam: organização do crédito agrícola, constituição de entrepostos comerciais (armazéns gerais); organização de engenhos para classificação de café; desenvolver ações para difundir o café no exterior; defender com os poderes legislativos federal e estadual a mudança da forma de introdução de imigrantes, possibilitando o estabelecimento da pequena propriedade policultora; incentivar o ensino agrícola e a propagação de novas técnicas de cultivo. A respeito do crédito agrícola, dizia-se que a sociedade deveria organizá-lo por meio de cooperativas agrícolas, que operassem sobre penhor agrícola ou bilhetes de mercadorias e warrants $^{227}$.

\footnotetext{
${ }^{224}$ Essa sociedade foi constituída como resultado de um acordo realizado em 1896 entre os governos de São Paulo, Rio de Janeiro, Espírito Santo e Bahia para promover a expansão do consumo do café na Europa. ${ }^{225}$ Correio Paulistano, 18/6/1900, p.1, "Propaganda do Café Brasil".

${ }^{226}$ Correio Paulistano, 23/2/1902, p.1, "Associação Agricola Commercial”; O Commercio de São Paulo, 24/2/1902, p. 2, "Centro Agricola Commercial Paulista".

${ }^{227}$ O Commercio de São Paulo, 9/2/1902, p.1, “Associação Agricola Commercial paulista”.
} 
Em 1901, houve um agravamento da crise do café, que se somava à diminuição do fluxo de imigrantes e ao aumento dos conflitos salariais. Além disso, uma crise bancária atingira o Rio de Janeiro, tendo repercussões em São Paulo com a quebra do Banco de Crédito Real e de vários pequenos bancos do interior de São Paulo que funcionavam desde $1890^{228}$.

Em julho de 1901, a comissão municipal de agricultura de Brotas enviou uma petição ao Congresso Legislativo, informando que os lavradores daquele município haviam deliberado reduzir conjuntamente os salários dos colonos e o valor pago pela colheita e solicitavam do Congresso medidas no sentido de reduzir as tarifas ferroviárias que seriam responsáveis por $20 \%$ de seus custos de produção. Pedia-se, principalmente, a realização de uma reunião, com caráter oficial, em que os presidentes das comissões municipais de agricultura pudessem expor a opinião dos fazendeiros ${ }^{22}$.

No ano seguinte, em 2 de julho, a Secretaria da Agricultura enviou uma circular às comissões municipais de agricultura solicitando que fosse realizada uma consulta aos lavradores a fim de se levantar opiniões a respeito dos meios a serem adotados para minorar os efeitos da crise. No geral, as propostas incluíam medidas relativas ao crédito agrícola, a proibição de novas plantações de café, proibição da exportação de cafés de baixa qualidade e adoção do plano de valorização apresentado por Quintino Bocaiúva, presidente do Rio de Janeiro ${ }^{230}$.

A reunião de fazendeiros, proposta pelo Clube da Lavoura de Brotas em julho de 1901, foi realizada em 21 de julho de 1902 em Ribeirão Preto (sede do $3^{\circ}$ distrito agronômico) e contou com a participação de representantes de 16 municípios. A reunião foi presidida por Francisco Ferreira Ramos, membro da Sociedade Paulista de Agricultura $^{231}$ e aprovou as seguintes deliberações: $1^{\text {o }}$ ) aprovação de um imposto proibitivo sobre novas plantações de cafés, $2^{\circ}$ ) eliminação dos cafés de escolha, os cafés de baixa qualidade, que deprimiam o preço do produto brasileiro; $3^{\circ}$ ) Adoção do projeto

\footnotetext{
228 A liquidação do Banco de Crédito Real em 1899 havia proporcionado grande constrangimento à lavoura, visto que os descontos das letras hipotecárias fornecidas aos fazendeiros a título de empréstimos pelo banco haviam se desvalorizado e os fazendeiros não conseguiam repassá-las sem um elevado deságio, fato que havia contribuído para que vários clubes da lavoura reivindicassem uma moratória da dívida hipotecária. ${ }^{229}$ SAO PAULO. ALESP: ACERVO HISTÓRICO. Documento n. 40.050, lata 295 "Providencia sobre os meios de minorar os effeitos...", p. 204-8.

${ }^{230}$ SAO PAULO. ALESP: ACERVO HISTÓRICO. Documento n. 40.050, lata 295 "Providencia sobre os meios de minorar os effeitos...", p. 210-8.

${ }^{231}$ Em 1902, Rodrigues Alves assumiria a presidência da República. Embora sua posse estivesse marcada para novembro, quem assinou a mensagem enviada ao Congresso Legislativo, em meados daquele ano, foi o seu vice, Domingos de Moraes.
} 
de valorização apresentado pelo presidente do Rio de Janeiro, Quintino Bocayuva, mediante convênio com os estados produtores; $4^{\circ}$ ) auxiliar a criação de cooperativas agrícolas, $5^{\circ}$ ) abolição dos impostos interestaduais sobre o café, para que parte dos grãos de baixa qualidade pudesse ser escoado para os demais estados; $5^{\circ}$ ) fazer representar-se o Brasil na exposição internacional do café que se realizaria em Nova York no ano de 1903 e, por fim, 6º aceitação das medidas propostas pela Sociedade Paulista de Agricultura, conforme sua assembleia de 25 de julho ${ }^{232}$.

A limitação do cultivo fora proposta por Augusto Ramos no âmbito da Sociedade Paulista de Agricultura ${ }^{233}$.

A participação do governo, via Secretaria da Agricultura e Sociedade Paulista de Agricultura, na reunião de lavradores em Ribeirão Preto, mostra que o executivo obteve sucesso ao criar as comissões municipais de agricultura, cooptando as lideranças locais e impedindo que os clubes da lavoura dessem encaminhamento contestatório ao debate. No entanto, o trabalho de cooptação das lideranças oposicionistas deixara ainda algumas arestas. Em agosto de 1902, ocorreu na cidade de Ribeirão Preto, sede do $3^{\circ}$ distrito agronômico, uma nova reunião de lavradores, em que, diferentemente daquela realizada em julho pelas comissões municipais de agricultura, observara-se a radicalização dos discursos e o reaparecimento da proposta de criação de um partido da lavoura. Um dos fazendeiros presentes nessa reunião, Carlos de Moraes Barros, conclamava os lavradores à disputa política: formem um grande partido da lavoura e verão se hão de ser ou não ouvidos, outro fazendeiro, Amaral Barros, ia além e conclamava à revolução da lavoura como caminho de obter seus objetivos e a destruição dos trilhos das estradas de ferro seria o ato inicial ${ }^{234}$.

\subsection{O PRP rumo ao congraçamento}

Os acontecimentos políticos sucedidos entre 1899 e 1903 modificaram a forma como o governo estadual conduzia a crise. Bernardino de Campos, em 1903, enviou ao Congresso Legislativo um projeto de lei para apreciação da Comissão Especial que incorporava reivindicações dos fazendeiros, em que se manifestavam algumas das

232 SAO PAULO. ALESP: ACERVO HISTÓRICO. Projeto s/nº. Documento 33.592, lata 60.

233 SOCIEDADE PAULISTA DE AGRICULTURA, COMMERCIO E INDUSTRIA, 1902, op. cit.; Ver também NOZOE, Nelson Hideiki, São Paulo: Economia cafeeira e urbanização, Estudo da Estrutura tributária e das atividades economicas da capital paulista (1889-1933). São Paulo, p. 20.

${ }^{234}$ CASALECCHI, 1987, op. cit., p. 123. 
medidas executadas em 1906, como a execução do programa de valorização do café e a criação de bancos agrícolas e cooperativas de crédito, entretanto, nenhuma das medidas previstas na lei 866 de 1903 fora colocada em prática em seu governo ${ }^{235}$.

$\mathrm{Na}$ segunda quinzena de agosto, o relatório do inspetor do mesmo $3^{\circ}$ distrito agronômico, sediado em Ribeirão Preto, afirmava que os ânimos estavam aflorados naquela zona, principalmente após a severa geada que atingiu grande parte dos cafezais nas bordas do Rio Moji. Dias depois, em 24 de agosto, eclodia uma rebelião armada que objetivava depor o presidente Campos Salles (cujo mandato terminaria em 15 de novembro) e restabelecer a monarquia. Durante três dias, várias cidades do interior estiveram sublevadas.

De acordo com Casalecchi, a revolta alertou o governo e o seu partido para a situação explosiva da lavoura, até então encaminhada de forma pacífica, através dos seus Congressos ${ }^{236}$. O movimento foi sufocado rapidamente e um inquérito foi aberto para indiciar os envolvidos. No entanto, deflagrava-se uma nova luta nos tribunais para julgar os envolvidos, em 16 de setembro de 1902, o Correio Paulistano publicou a lista dos indiciados, na qual constavam membros importantes do poder oligárquico. O judiciário e o governo trataram de abafar a situação, o que indicava a existência de algum tipo de negociação.

Diante dessa nova tensão, em janeiro de 1903, realizou-se um novo congresso da lavoura, entre os participantes, encontravam-se os nomes de fazendeiros relacionados anteriormente ao Partido da Lavoura, a maioria deles monarquistas. O presidente do congresso, Barão Geraldo Rezende, determinou que nesse congresso não haveria deliberações, pois apenas seriam apresentadas propostas a respeito da valorização do café. Diferentemente dos congressos realizados anteriormente, não se observou a concorrência de discursos políticos inflamados. Foi eleita uma comissão incumbida de discutir e sintetizar as propostas dos fazendeiros e enviá-las ao governo ${ }^{237}$.

O secretário de fazenda, Mello Peixoto, apresentou em seu relatório as linhas gerais da proposta enviada pela comissão do congresso de 1903 e comparando-as com aquelas propostas apresentadas na reunião de lavradores de julho de 1902, observa-se que

\footnotetext{
${ }^{235}$ Bernardino, 1903, pp. 11-13.

236 Idem, p. 121.

${ }^{237}$ Eram membros da comissão do congresso dos lavradores o Barão Geraldo Rezende, Antônio da Silva Prado, José de Queiroz, Alfredo Guedes e Ignácio Uchôa, a maioria deles monarquistas e comerciantes de café. Cf. Correio Paulistano, 2-4.2. 1903. "Congresso dos Lavradores".
} 
a proposta da comissão tendia muito mais aos interesses do setor comercial do complexo cafeeiro. Muitas das medidas são basicamente as mesmas propostas em 1902, tais como eliminação dos cafés de baixa qualidade, redução das tarifas ferroviárias e eliminação dos impostos interestaduais para escoar o café de escolha por cabotagem. A diferença estava nos itens que diziam respeito ao crédito e a respeito da lei que determinou o imposto proibitivo sobre novos cafezais. Pela proposta da comissão, o governo deveria auxiliar os bancos comerciais já existentes a financiar a lavoura por intermédio dos comissários de café, o que na prática era a manutenção do sistema em vigor potencializado pelo subsídio estatal $^{238}$. Enquanto isso, a proposta dos lavradores de Ribeirão Preto pugnava-se pela criação de cooperativas de crédito e a criação de um banco agrícola que emprestasse diretamente aos fazendeiros ${ }^{239}$.

O acirramento cada vez maior do debate político acabaria por modificar a forma como o governo paulista encarava a crise e também a condução da política econômica.

Bernardino de Campos, que havia assumido a presidência do estado em 1903, demonstrou maior sensibilidade política que seus antecessores com relação aos reclamados auxílios à lavoura. O relatório de seu secretário de fazenda, João Batista de Mello Peixoto, distinguia-se claramente daqueles apresentados por Francisco Malta e Rodrigues Alves nos anos anteriores e que corroboravam com as teses de Murtinho sobre a superprodução de café. Mello Peixoto demonstrava ter uma leitura da crise que era muito mais agradável aos lavradores e condizente com suas reivindicações, ele dizia que a lucratividade havia caído abaixo do custo de produção e que o sistema de crédito existente não podia mais suprir as necessidades de financiamento da lavoura. Por um lado, o capitalista, receoso de empate nas fazendas, demandava agora outros empregos, de preferência os imóveis da Capital, os títulos das melhores empresas de vias férreas ou de outras indústrias, enquanto o comércio comissário ficou impossibilitado de manter os adiantamentos que sempre fez à lavoura e restringiu consideravelmente o papel de sua carteira de custeios, propendendo demais a mais a constituir-se exclusivamente como intermediário nas vendas do café2 240 .

\footnotetext{
${ }^{238}$ SÃO PAULO. SECRETARIA DA FAZENDA. Relatorio Apresentado ao Exm. Sr. Dr. Domingos Correa de Moraes, vice-presidente do estado de São Paulo pelo Dr. Firmiano de Moraes Pinto, Secretario de Estado dos Negocios da Fazenda. São Paulo Diario Oficial 1903, pp. 10-11.

${ }^{239}$ SÃO PAULO. SECRETARIA DA FAZENDA, 1903, op. cit., pp. 9-10 e Correio Paulistano, 2-4.2. 1903, p.2, "Congresso dos Lavradores".

${ }^{240}$ SÃO PAULO. SECRETARIA DA FAZENDA, 1903, op. cit., pp. 3-4.
} 
No mesmo ano, o presidente Bernardino de Campos afirmava em sua mensagem anual ao Congresso Legislativo que desde 1896 já se havia verificado que a crise era de caráter financeiro e não econômico e que embora a superabundância do produto fosse tida por muitos como a principal causa da crise, ela constituía um meio no qual se elaboravam especulações de efeitos ainda mais graves.

Tanto o presidente como seu secretário de fazenda acenavam para os lavradores com a possibilidade de intervir no mercado de crédito.

Em 1904, ocorria mais uma vez a troca de comando no governo estadual, assumindo a presidência o experiente e respeitado Jorge Tibiriçá, primeiro presidente do estado. Naquele momento, a rebeldia da lavoura atingia novamente o seu clímax. Bernardino de Campos, ao passar o cargo para seu sucessor fez o seguinte alerta a Tibiriçá: "Jorge, você vai governar com um espinho atravessado na garganta - a dissidência" ${ }^{241}$. Os dissidentes do PRD, que reivindicavam uma reforma eleitoral e pregavam o boicote eleitoral, criaram em 1905 a Liga Republicana que reuniu em seu Congresso dissidentes de todos os matizes. Em abril de 1906, fizeram uma reunião das oposições, presidida por Cerqueira Cesar, onde compareceram representantes de cerca de 60 municípios, mas que apresentava um programa bastante genérico ${ }^{242}$. Como reação à Liga, o PRP convocou um Congresso para setembro que viria a ser o mais concorrido da República, em que algumas das reivindicações foram atendidas, como a elevação do número de integrantes da Comissão Central de cinco para nove membros, oferecendo-se as novas vagas aos líderes das principais alas dissidentes. Além disso, foi decidido que as chapas eleitorais deveriam passar pela consulta prévia dos diretórios municipais.

Jorge Tibiriçá, ao mesmo tempo, pôs em prática um processo de negociações com as alas descontentes da oligarquia, convidando muitos deles para compor o seu secretariado, inclusive propagadores do Partido Monarquista. Além do agravamento da crise e a vitória do projeto intervencionista sobre o liberal, havia outros elementos que contribuíram para unificar politicamente os cafeicultores, como o movimento grevista que estourou nas companhias ferroviárias em maio de 1906.

Em seu programa de governo, Tibiriçá havia incluído várias das reivindicações oposicionistas, tais como a reformulação da constituição estadual, uma reforma eleitoral

${ }^{241}$ CASALECCHI, 1987, op. cit., pp. 124-5.

${ }^{242}$ Idem, ibdem., p. 126. 
e o atendimento das necessidades da lavoura. Seu governo foi responsável pelo chamado "congraçamento", processo de reorganização do PRP e assimilação das dissidências, concluído durante o congresso do PRP de setembro de $1906^{243}$. Finalmente, a execução do plano de valorização e a criação da Caixa de Conversão jogaram uma pá de cal sobre as dissidências e o clima de congraçamento tomou conta do cenário político e no fim daquele ano os dissidentes históricos fariam uma homenagem a Jorge Tibiriçá.

Foi no governo de Jorge Tibiriçá que as medidas aprovadas em 1903 começaram a ser aplicadas, de modo que em 8 de agosto de 1904 foi aprovada a Lei n. 923 que fornecia garantais cambiais ao capital estrangeiro investido no banco agrícola ${ }^{244}$, lei que dava aplicação à lei 866 e revogava outra lei de 1902, que também estabelecia auxílios à criação de um banco agrícola ${ }^{245}$. Em 1905, o governo paulista entrou em negociação com um consórcio de capitalistas franceses que resultou, em 1908, na assinatura de um contrato para organização do Banco de Crédito Hipotecário e Agrícola do Estado de São Paulo, que entrou em operação em $1909^{246}$. Em 1906, foi aprovada a lei estadual n ${ }^{\circ} 1.062$, que provisionava um auxílio às cooperativas de crédito chamadas Bancos de Custeio Rural, cujo projeto de lei tramitava no Congresso desde 1903, esses bancos entraram em funcionamento em 1907 e se espalharam rapidamente pelo interior paulista.

${ }^{243}$ Idem, ibdem., 126

${ }^{244}$ Lei n. 923, de 8 de agosto de 1904, “Transforma em ouro as garantias dadas pelo Estado aos bancos da credito agrícola".

${ }^{245}$ Lei n. 865, de 17 de dezembro de 1902.

246 SÃO PAULO, Relatorio Apresentado ao Dr. Jorge Tibiriçá, Presidente do Estado, Pelo Dr. Olavo Egydio de Souza Aranha, Secretario da Fazenda, 1907, São Paulo: Typ. do Diario Official, 1908. 


\section{O SINDICALISMO AGRÁRIO E A ORIGEM DO COOPERATIVISMO DE CRÉDITO NO BRASIL}

Na segunda metade do século XIX as cooperativas de crédito tornaram-se muito populares na Europa continental, principalmente na Alemanha e na França. A difusão dessas instituições se explica, por um lado, pela ausência do crédito bancário nas zonas rurais assim como no atendimento à demanda de pequenos empréstimos requeridos por pequenos comerciantes e artesãos que não atraíam a atenção do crédito bancário. Essas cooperativas cumpriam a função de concentrar esses pequenos empréstimos e conferirlhes a credibilidade advinda da responsabilidade mútua, atraindo para elas o crédito bancário. Por outro lado, a organização de cooperativas agrícolas inseria-se no contexto do movimento agrário que se opunha ao liberalismo econômico e que tinha profunda inspiração católica.

Na França e na Alemanha, surgiram dois modelos de associações rurais que influenciariam diretamente as experiências brasileiras, tanto na organização de sociedades agrárias como na constituição de cooperativas de crédito. O chamado movimento do catolicismo social apoiava amplamente a criação de associações de agricultores católicos e a organização de caixas de crédito e cooperativas para aquisição de insumos e venda de produtos.

$\mathrm{Na}$ Alemanha, a reação dos produtores à crise agrária se confundia, em algumas regiões, com o movimento de restauração católica, particularmente forte na Renânia e na Westfália. Esse movimento conseguiu estruturar uma influente rede de instituições de caráter civil, cuja maior expressão eram os congressos católicos (Katholikentage) que reuniam delegados católicos de localidades de todo o império e chegou a formar um partido, o Partido do Centro. Após a publicação da Encíclica Rerum Novarum, o catolicismo social alemão buscou organizar associações de caráter multiprofissional, as uniões populares (Volksverein) que, por sua vez, promoviam a criação de sociedades de auxílio mútuo e clubes agrícolas (Bauernverein) nas quais se organizavam caixas rurais. Este, por exemplo é o modelo que os imigrantes católicos alemães reproduziram na colônia do Rio Grande do Sul, pioneira na criação de caixas rurais no Brasil e que abordaremos mais adiante ${ }^{247}$.

247 VOGT, Olgário Paulo \& Roberto RADÜNZ, "De matriz conservadora a uma postura progressista: catolicismo social no Rio Grande do Sul - RS - Brasil", Redes, v. 18, n. 2, p. 124-141, 2013; SCHALLENBERGER, Erneldo. "Cooperativismo e desenvolvimento comunitário". Mediações-Revista de Ciências Sociais, v. 8, n. 2, p. 9-26, 2003. 
$\mathrm{Na}$ França, surgiu um sistema hierarquizado de sociedades agrícolas cuja base era formada por sindicatos de caráter local que funcionavam como locus de discussão dos interesses agrários da localidade e ao mesmo tempo como uma espécie de cooperativa ao realizar a aquisição de implemento para uso coletivo e a compra de adubos no atacado e que eram distribuídos a preço de custo aos associados. Ao lado dos sindicatos agrícolas funcionavam caixas rurais e cooperativas para a venda de produtos. Enquanto os sindicatos locais eram filiados a sociedades agrícolas de caráter nacional, e havia mais de uma, as caixas de crédito funcionavam interligadas a caixas centrais que centralizavam suas operações de crédito e exerciam controle sobre sua organização e estavam, por sua vez, submetidas a sociedades regionais e nacionais de agricultores ou ao governo. Esse modelo de organização agrícola influenciaria a criação da Sociedade Nacional de Agricultura em 1897 e a aprovação da lei n. 979 de 1903, que autorizou a criação de sindicatos agrícolas de 1903.

Ao longo deste capítulo pretendemos abordar rapidamente os modelos de cooperativas de crédito, discutindo suas influências e demonstrando um aspecto de sua assimilação no Brasil em torno das discussões que culminariam na criação dos Bancos de Custeio Rural.

\subsection{Difusão do cooperativismo de crédito na Europa}

As primeiras sociedades cooperativas foram concebidas como instrumento de resistência dos trabalhadores às duras condições de vida nas cidades industriais inglesas no início do século XIX ${ }^{248}$, a exemplo dos clubes de consumo constituídos sob orientação socialista, os quais funcionavam, muitas vezes, como braço econômico das organizações políticas do movimento operário ${ }^{249}$. Paralelamente ao cooperativismo socialista, surgira na Alemanha e na França uma vertente de caráter religioso. O cooperativismo chamou

${ }^{248}$ Em que pesem as primeiras sociedades cooperativas datarem do fim do século XVIII, foi no início do século XIX que elas proliferaram em centros industriais ingleses com o objetivo de satisfazer necessidades básicas dos trabalhadores. Caberia, entretanto, a Robert Owen a formulação de um conjunto de diretrizes organizacionais que diferenciavam a sociedade cooperativa das sociedades anônimas, tais como: a igualdade de voto, independentemente do número de cotas em poder de um participante; limitação dos lucros e a criação de um fundo ou patrimônio mútuo indivisível. A primeira associação a seguir tais diretrizes foi organizada em Roshdale (Manchester) em 1844 e os seus estatutos serviriam de modelo a inúmeras experiências que se espalhariam pela Europa ao longo da segunda metade do século XIX. $C f$. José Luis Monzón Campos, "El cooperativismo en la historia de la literatura económica", Ciriec-España, n. 44, p. 9-32, 2003.

${ }^{249}$ KOCKA, Jürgen and Marina Sanchis MARTÌNEZ, "Los artesanos, los trabajadores y el Estado: hacia una historia social de los comienzos del movimiento obrero alemán", Historia Social, n. 12, p. 101-118, 1992. 
também a atenção de economistas burgueses que tentavam refletir e adaptar seus preceitos doutrinários ao programa econômico liberal, surgindo uma corrente liberal que ganharia destaque nas últimas décadas daquele século. Tal como as correntes religiosas, a vertente liberal buscava atenuar o caráter reformador das doutrinas socialistas, promovendo a conciliação de classe. Ao longo desse século, entretanto, surgiram diversas modalidades de sociedades para fins mutualísticos como as associações de seguros, muitas das quais de caráter beneficente e que remontavam aos montes da piedade; as cooperativas de produção artesanal e agrícola e as cooperativas de construção habitacionais de crédito que tinham orientações das mais diversas, desde a influência do socialismo francês, passando pelo liberalismo às tendências cristãs como as caixas rurais Raiffeisen e toda a marcante obra do catolicismo social.

No que diz respeito às cooperativas de crédito existem duas modalidades principais, os chamados bancos populares e as caixas rurais. Os bancos populares têm abrangência urbana e tinham orientação liberal enquanto que as caixas rurais estavam orientadas por princípios cristãos e se constituíram em um importante instrumento de propagação do catolicismo. Na França e na Bélgica, a organização das caixas rurais estava intimamente relacionada ao movimento agrário que compreendia a organização de sindicatos rurais e sociedades agrícolas. Esse movimento, que resultava da insatisfação dos agricultores com a depressão econômica iniciada na década de 1870, tinha em sua maioria inspiração católica e encarava a organização de sindicalismo agrícola e cooperativismo de crédito como parte da obra de fortalecimento da religião católica contra o socialismo e o liberalismo.

No fim do século, o cooperativismo tinha, incontestavelmente, uma enorme importância social e adquiria cada dia mais importância econômica, visto que grande parte dessas associações havia se inserido, de alguma forma, no processo de reprodução do capital. Na prática, a cooperação mútua havia se tornado uma forma de dinamizar certos setores que permaneciam à margem do mercado - como era o caso do acesso ao crédito, indisponível para grande parcela dos agentes econômicos, além de dinamizar a produção camponesa, como foi o caso das cooperativas de viticultores e de produtores de açúcar. Desse modo, enquanto as cooperativas de consumo permitiam aos operários adquirir bens de consumo no atacado e com preços reduzidos, as sociedades construtoras possibilitavam à classe média e mesmo a operários a aquisição de imóveis. Enquanto isso, as cooperativas rurais permitiam que camponeses pudessem adquirir, em conjunto, 
adubos e implementos agrícolas que, de outro modo, estariam disponíveis apenas aos proprietários com grande poder aquisitivo ou aos que possuíssem acesso ao crédito hipotecário.

As cooperativas de crédito abriam crédito e captavam a poupança de artesãos, pequenos comerciantes e camponeses ignorados pelas instituições bancárias, fosse porque os bancos estavam concentrados nas grandes cidades, fosse porque não viam interesse nessas operações minúsculas ou porque não tinham condições de auferir a sua liquidez desses indivíduos. Por outro lado, o associativismo, ao permitir que diversos setores adquirissem produtos e serviços, criava demandas que se encontravam reprimidas. Assim, os camponeses associados tornavam-se consumidores de implementos e fertilizantes, enquanto as cooperativas de crédito abriam a pequenos produtores e comerciantes as portas do mercado formal de crédito.

Os Estados germânicos foram um grande laboratório de experiências com instituições de crédito agrícola no início do século XIX, quando surgiram e se disseminaram os bancos territoriais emissores de letras hipotecária, reproduzidos posteriormente no restante do continente e na América. Em meados daquele mesmo século surgia outra forma de instituição, as caixas de crédito e os bancos populares, organizados como cooperativas e que se disseminaram após a unificação alemã. Consistiam-se de associações de poupança e crédito cujo surgimento remonta à crise econômica da década de 1840 que atingiu duramente o mundo rural e urbano. Na segunda metade do século haviam se constituído dois modelos de cooperativas de crédito, bem distintos e que gozariam de imenso prestígio e reconhecimento internacional, tratavamse das caixas rurais do sistema Raiffeisen (darlenkassen) e os bancos populares do sistema Schulze-Delitzsch (volksbanken). O primeiro, de caráter religioso, antissocialista, antiliberal e voltado para o atendimento das necessidades de camponeses e pequenos proprietários e, o segundo, de inspiração liberal, tinha caráter liberal e estava voltado ao atendimento das necessidades de artesãos e pequenos comerciantes em relação ao crédito comercial.

As caixas rurais foram idealizadas por Friedrich Wilhelm Raiffeisen, um luterano que ocupava o cargo de burgomestre em uma localidade da Renânia e que concebeu um modelo associativo de caixas para realizar empréstimos a juros baixos. Ele havia criado, inicialmente, uma sociedade beneficente para auxiliar os camponeses em uma localidade de Heddesdorf na Renânia. Essa entidade era mantida pela igreja, com apoio da elite local 
e se encarregava da compra de gado e implementos que eram fornecidos a crédito aos camponeses. Mais tarde, em 1864, ele criou uma primeira cooperativa de crédito, denominada Associação de Caixas de Empréstimos de Heddesdorf, cujo objetivo era socorrer os camponeses e livrá-los da usura. A forma de organização dessas caixas guardava semelhança com os princípios desenvolvidos pelas cooperativas socialistas inglesas, tais como a igualdade de voto, indivisibilidade do patrimônio e inexistência de capital social e lucro, além da obrigatoriedade de serem constituídas apenas por camponeses que habitassem uma mesma localidade.

Enquanto isso, o prussiano Herman Schulze criou um sistema de cooperativas de crédito urbanas, tendo fundado em 1856, na cidade de Delitzsch, uma "sociedade para adiantamentos de dinheiro" cujo modelo ficaria conhecido como sistema SchulzeDelitzsch, ou simplesmente por bancos populares. Diferentemente de Raiffeisen, Schulze era um campeão do liberalismo econômico, adversário tanto de Raiffeisen como dos socialistas liderados por Ferdinand Lassalle. Em vez da caridade manifesta nas instituições promovidas por Raiffeisen, Schulze havia recorrido ao lucro como forma de atrair associados para seu banco popular que, além de voltados para a clientela de artesãos e pequenos comerciantes, não possuía limitação geográfica como as caixas Raiffeisen ${ }^{250}$. O banco popular Schulze-Delitzsch funcionava, na prática, como um pequeno banco comercial, seu formato associativo devia-se a possibilidade de fazer com que a responsabilidade solidária se constituísse em uma garantia para o bom funcionamento da instituição que, entretanto, realizava operações similares às dos bancos de depósito e descontos, mas em dimensões muito menores ${ }^{251}$.

Muito em breve, essas experiências pioneiras realizadas na Alemanha inspirariam o italiano Luigi Luzzatti, professor de economia política no Instituto Técnico de Milão, que divulgou as teorias de Herman Schulze em língua italiana e adaptou suas instituições à legislação e às necessidades italianas. Em 1863, Luzzatti publicou o livro La Diffusione del Credito e le Banche Popolari, no qual mesclou características das caixas Raiffeisen com as de Schulze-Delitzsch: seu modelo ficaria conhecido como bancos Luzzatti ${ }^{252}$.

\footnotetext{
${ }^{250}$ POULAT, Emile. “Gueslin (André) Les Origines du Crédit Agricole (1840-1914)”. Archives des sciences sociales des religions, v. 48, n. 2, p. 292-293, 1979.

${ }^{251}$ PINHEIRO, Marcos A. H., Cooperativas de Crédito História da evolução normativa no Brasil. Brasília: Banco Central do Brasil, 2008.

${ }^{252}$ Luigi Luzzatti foi ministro das Finanças da Itália em 1896 e 1903 e Primeiro Ministro em 1910.
} 
Da Alemanha para a Itália e depois para o resto do continente as cooperativas de crédito se difundiram rapidamente e adquiram enorme importância econômica, principalmente em países onde o crédito bancário não havia se difundido com a mesma intensidade observada na Inglaterra. Nesses países, as caixas rurais e os bancos populares exerceriam funções similares às dos pequenos bancos locais e regionais que sustentavam a capilaridade do sistema bancário britânico. Atuando localmente, essas associações tinham melhores condições para avaliar e distribuir o crédito, além de receber o depósito de pequenas poupanças e atuarem como intermediários dos bancos maiores.

No fim do século XIX esse tipo de associação de crédito havia atingido enorme envergadura. Karl Kautsky, ao analisar a questão agrária na Alemanha, discorreu longamente sobre o papel das cooperativas de crédito, ressaltando, além de sua importância social, o fato de elas estarem perfeitamente adaptadas aos recentes desenvolvimentos do capitalismo, pois, com a sobrevivência persistente da pequena propriedade camponesa e diante das transformações ocorridas no mercado de produtos agrícolas, a cooperativa se tornara a única forma com que camponeses e pequenos proprietários obtinham acesso ao crédito, indispensável para a modernização dos processos de cultivo, mas que estava vedado aos indivíduos de pequenas posses.

No trecho transcrito a seguir, Kautsky resume o papel dessas instituições ligando os agricultores ao capital bancário:

Se, por um lado, os empréstimos solicitados pelos lavradores individuais são pequenos demais para despertar o interesse do grande capital, os de uma cooperativa inteira desempenham, por outro lado, um papel bem diferente. Se um empréstimo concedido a um camponês desconhecido representa um sério risco para o banqueiro da cidade, a solidariedade dos cooperados reduz esse risco a um mínimo. Estabelece-se, dessa maneira, através das cooperativas de crédito, a possibilidade de o lavrador receber também dinheiro a juros módicos, juros que o mesmo será capaz de pagar sem arruinar a própria empresa, melhorando o esquema de sua produção. Sem dúvida alguma as cooperativas de crédito são da maior importância para o camponês, como meio de progredir economicamente. São meios de progresso econômico que não levam ao socialismo (conforme muitos pensam), mas ao progresso do capitalismo ${ }^{253}$.

A grande evolução dessas instituiçoes ocorreu após a década de 1870. Em 1871, havia pouco mais de 100 caixas rurais na alemanha e o seu número cresceria rapidamente atingindo 2.135 em 1890 e dobrado o seu número para 6.391 em $1896^{254}$. As caixas

${ }^{253}$ KAUTSKY, Karl. A Questão Agrária. São Paulo, Nova Cultural, 1986, pp. 109-10.

${ }^{254}$ Idem, p. 110. 
raiffeisen formavam redes articuladas por caixas centrais que as colocavam em contato com o sistema tradicional de crédito. Muitas dessas federações de cooperativas de crédito adquiriam grande importância e existem ainda hoje, como é o caso do holandês Rabobank (Raiffeisen Boerenleenbank), fruto da fusão da Cooperatieve Centrale Boerenleenbank com a Cooperatieve Centrale Raiffeisen-bank, constituídas em 1898. Assim, como o Credit Mutuel, importante banco fancês que tem origem na fusão de diversas caixas centrais que remontam à década de 1890 .

\subsection{Agrarismo: fusão dos sindicatos agrícolas com as caixas rurais}

Para que se possa compreender a difusão das caixas rurais na Europa neste fim de século e a sua influência sobre as propostas de cooperativimso de crédito que simultaneamente eram propagadas no Brasil, torna-se indispensável discutir, ainda que rapidamente, o contexto da crise agrária europeia e aquilo que Hobsbawm descreveu com o resultado mais importante dessa crise, o surgimento de um movimento agrário antiliberal $^{255}$ e a ideologia do catolicismo social que permeava uma grande parcela do movimento agrário, principalmente na Alemanha, França e Bélgica.

Nas décadas finais do século XIX a economia agrícola de diversos países passava por intensa transformação. Inicialmente, o desenvolvimento industrial havia elevado o consumo de gêneros primários possibilitando que os preços permanecessem elevados por largo período. Porém, a partir da década de 1870 os preços dos gêneros agrícolas apresentaram uma prolongada tendência de baixa que perdurou até meados da década de 1890. Até esse período, a agricultura europeia se encontrava relativamente protegida devido à barreira que altos custos do transporte marítimo ofereciam à concorrência colonial. Porém, a evolução das estradas de ferro e da navegação a vapor causou uma expansão do mercado de grãos, possibilitando, por exemplo, que o trigo do Canadá, Argentina e Estados Unidos entrassem no mercado consumidor europeu. Eric Hobsbawm, ao analisar o alcance da chamada grande "depressão", afirmava que não houvera uma verdadeira crise econômica com diminuição do nível da produção industrial, mas prolongada depressão dos preços e contração da taxa de lucro, depressão que atingira mais seriamente o mundo agrícola que o urbano.

${ }^{255}$ HOBSBAWM, Eric J. A era dos impérios. Rio de Janeiro, Paz e Terra, 2012. 
Dizia Hobsbawm que a agricultura foi a vítima mais espetacular desse declínio dos lucros e o setor cujo contentamento teve consequências políticas mais imediatas e de maior alcance $e^{256}$. A reação agrária havia variado de acordo com o país, passando da agitação eleitoral às revoltas camponesas como as que eclodiram na Irlanda, Sicília e Romênia. Lembra ainda Hobsbawm, que os anos de 1880 conheceram as mais elevadas taxas de imigração ultramarina da história, mecanismo que acabava funcionando como válvula de escape em países como Alemanha, Irlanda e Itália. Por conta da importância demográfica e eleitoral do mundo rural, os governos europeus se demonstraram bastante suscetíveis à pressão exercida pelo setor agrícola, enquanto o campo havia se transformado em um importante espaço da disputa política ${ }^{257}$.

O descontentamento do camponês permitira aos partidos conservadores conquistar espaços importantes nos parlamentos perante os partidos liberais.

Na década de 1890, o irrompimento da questão agrária na França e na Alemanha tomava de surpresa os partidos socialistas. Segundo Karl Kautsky, o crescimento eleitoral da social-democracia alemã passara a depender diretamente da conquista do voto camponês. No entanto, o partido não tinha um programa agrário e a admissão das reivindicações camponesas causava constrangimento e divergências. Marx havia previsto que o desenvolvimento capitalista causaria a dissolução da pequena exploração camponesa em favor da exploração capitalista, inversora de capital e especializada. Entretanto, o que se observava naquele momento era o contrário, aumento da renda fundiária e a incorporação dos pequenos proprietários ao mercado ${ }^{258}$. Engels, que havia terminado a redação do livro terceiro de $O$ Capital em 1895, confirmara a expectativa na transformação do quadro agrícola, ao afirmar que o desenvolvimento dos vapores transoceânicos e das estradas de ferro norte e sul-americanas e indianas inundariam os mercados europeus de trigo barato. Felizmente, dizia Engels, nem todas as terras de estepes passaram a ser cultivadas; ainda há o suficiente para arruinar toda a grande propriedade fundiária europeia e, ainda por cima a pequena ${ }^{259}$.

Em 1899, no congresso do Partido Social-Democrata alemão de Erfurt, a aprovação de um programa agrário causaria uma cisão no partido. Um dos temas mais

\footnotetext{
${ }^{256}$ HOBSBAWM, 2012, op. cit., p. 60.

${ }^{257}$ Idem, ibdem.

${ }^{258}$ KAUSTSKY, 1986, op. cit.

${ }^{259}$ MARX, K. O capital: Crítica da economia política (volume 3, tomo 2, O processo global da produção capitalista). São Paulo: Nova Cultural, 1986, p. 203.
} 
polêmicos desse programa dizia respeito ao papel das cooperativas agrícolas e das caixas rurais de crédito ${ }^{260}$. Como lembra Kautsky, o mundo rural transformara-se em um desafio político para a social-democracia e um problema aos teóricos marxistas ${ }^{261}$. Ao escrever $A$ Questão Agrária, Kautsky absorveu muitas das críticas apontadas contra O Capital e buscou redefinir o conceito de agricultura capitalista, mostrando que o capitalismo ao invés de destruir aquela estrutura social, transformava-a na medida em que a incorporava ao seu processo de reprodução e as cooperativas e as caixas rurais de crédito cumpririam um importante papel nesse processo, possibilitando que a agricultura, não apenas a pequena, mas também a grande, pudesse modernizar seu processo de cultivo ${ }^{262}$.

Por outro lado, um dos resultados da reação agrária foi o combate ao liberalismo econômico e a defesa do protecionismo agrícola. Essa reação se expressava em um tipo de movimento que tomou corpo não apenas na Europa, mas também nos Estados Unidos, que é denominado agrarismo.

Nos Estados Unidos, a reação agrária à depressão refletia o descontentamento dos agricultores com os juros do financiamento e as tarifas das estradas de ferro, cujo peso havia se tornado muito grande diante da contração do lucro. Esse descontentamento culminara na criação das farmers alliances, sociedades locais de agricultores que se reuniam em federações que se estabeleciam em lócus de discussão dos interesses agrários, por meio das quais se pressionava congresso e governo para que interviesse nas tarifas ferroviárias e no mercado de crédito, aumentassem a circulação monetária e cobravam o estabelecimento de barreiras alfandegárias. Na década de 1890, durante o auge da revolta agrária esse movimento logrou organizar o Partido Populista, com o qual disputaram as eleições presidenciais ${ }^{263}$.

A igreja católica teve papel fundamental nos conflitos suscitados pela crise agrícola, principalmente, por meio da doutrina do catolicismo social, incentivada pelo Papa Leão XIII através da Encíclica Rerum Novarum de 1891. O documento, endereçado aos bispos, defendia a caridade e o direito à sindicalização, ao mesmo tempo em que condenava o liberalismo e o socialismo.

\footnotetext{
${ }^{260}$ KAUTSKY, 1986, op. cit.

${ }^{261}$ Cf. KAUTSKY, 1986, "Introdução"; ANDERSON, Perry. Considerações sobre o marxismo ocidental, São Paulo, Boitempo, 2004.

262 KAUTSKY, 1986, op. cit.

${ }^{263}$ LINK, Arthur S. História moderna dos Estados Unidos, Rio de Janeiro, Zahar, 1965, p. 30.
} 
$\mathrm{Na}$ Alemanha, a reação agrária confundia-se, em muitas regiões, com o movimento da restauração católica, particularmente forte na Renânia e na Westfália. Esse movimento conseguiu estruturar uma influente rede de instituições de caráter civil cuja maior expressão eram os congressos católicos (Katholikentage) que reuniam delegados católicos de localidades de todo o império e que chegou a formar um partido, o Partido do Centro. Após a publicação da Encíclica Rerum Novarum, o catolicismo social alemão buscou organizar associações de caráter multiprofissional como a União Popular (Volksverein) que, por sua vez, promoviam a criação de sociedades de auxílio mútuo e clubes agrícolas (Bauernverein), junto aos quais se organizavam caixas rurais segundo o modelo Raiffeisen. Esse tipo de organização foi reproduzido no Brasil pela colônia alemã do Rio Grande do Sul, pioneira na criação de caixas rurais pelo modelo Raiffeisen no Brasil e que abordaremos adiante ${ }^{264}$.

Assim como na Alemanha e na França, a difusão das caixas de crédito estava intimamente relacionada ao catolicismo social. Segundo o pesquisador francês, Emile Poulat, o crédito agrícola, antes de 1914, era uma das joias do catolicismo social ${ }^{265}$. A difusão das caixas rurais estava, por sua vez, intimamente relacionada à criação de sindicatos rurais promovidos pela tradicional Société des Agriculteurs de France (SAF), entidade que congregava grandes proprietários de terras e tinha influência católica. Essa entidade ficou conhecida como sociedade dos duques e marqueses, devido a suas posições aristocráticas.

Em 1881, foi aprovada a lei de liberdade sindical, que permitia a organização de associações de classe por operários e agricultores. Nos anos seguintes a Société des Agriculteurs de France (SAF) promoveu intensamente a criação de sindicatos rurais de caráter local e regional que posteriormente viriam a se congregar em federações de sindicatos como a Union Centrale des Syndicats Agricoles, fundada em 1886 com apoio da SAF, além da Union du Sud-Est, fundada em Lion no ano de $1888^{266}$. Como havia se transformado em espaço de intensa disputa política, os republicanos buscaram organizar sua própria sociedade de agricultura, criando a Société d'Encouragement à l'Agriculture

\footnotetext{
${ }^{264}$ VOGT \& RADÜNZ, 2013, op. cit.; SCHALLENBERGER, Erneldo. "Cooperativismo e desenvolvimento comunitário". Mediações-Revista de Ciências Sociais, v. 8, n. 2, p. 9-26, 2003.

${ }^{265}$ POULAT, Emile. "Gueslin (André) Les Origines du Crédit Agricole (1840-1914)". Archives des sciences sociales des religions, v. 48, n. 2, p. 292-293, 1979.

${ }^{266}$ NICOLAS, Philippe. "Emergence, développement et rôle des coopératives agricoles en France. Aperçus sur une histoire séculaire", Économie rurale, v. 184, n. 1, p. 116-122, 1988, p. 116.
} 
que, por sua vez, ficaria conhecida como sociedade dos ministros e futuros ministros dada a sua ligação com o Estado ${ }^{267}$.

Outra expressão do agrarismo francês era o movimento retour à la terre, idealizado por Jules Méline, político republicano, defensor das instituições liberais internas, mas ao mesmo tempo, um dos maiores responsáveis pelo intervencionismo em relação à política externa, como na defesa das tarifas protecionistas que foram aprovadas em 1892 e que eram conhecidas por tarifs Méline ${ }^{268}$. No que dizia respeito ao estabelecimento do crédito agrícola, os liberais republicanos liderados por Méline eram contrários à criação de bancos estatais para provimento de crédito aos agricultores e foi sob essa perspectiva que eles se voltaram para a utilização do mutualismo como forma de organizar o crédito agrícola, aproveitando-se da expansão dos sindicatos agrícolas observada desde 1881. Méline propusera à Assembleia Nacional um projeto de lei em 1890 para fomentar instituições de crédito agrícola, o qual tinha por base as experiências alemãs com as caixas rurais ${ }^{269}$.

O maior propagador das ideias de Raiffeisen na França era Louis Durand, um jovem advogado de Lion que, em 1890, foi encarregado pela Union du Sud-Est para estudar o projeto de crédito agrícola proposto por Jules Méline ${ }^{270}$. Durand publicou em 1891 o livro Le Credit Agricole en France et a l'Étranger e, em 1893, o Manuel Pratique à l'Usage des Fondateurs et Administrateurs des Caisses Rurales. O seu modelo de caixas rurais, conhecido como Raiffeisen-Durand, transformara-se em um padrão para a organização desse tipo de instituição na França e também no exterior.

Durante a década de 1890 houve uma grande expansão do número de cooperativas e caixas rurais que seguiam o modelo Raiffeisen. As caixas rurais e as cooperativas agrícolas funcionavam localmente sob a direção dos sindicatos agrícolas. Segundo Philippe Nicolas, nessa mesma década a corrente corporativista (aristocrática e católica) controlava grande parte dos sindicatos agrícolas e das caixas de crédito na França e contava com a concorrência dos republicanos que buscavam submeter as caixas rurais à

\footnotetext{
${ }^{267}$ MENDRAS, Henri. "Les organisations agricoles et la politique". Revue Française de Science Politique, v. 5, n. 4, p. 736-760, 1955; NICOLAS, Philippe, "Emergence, développement et rôle des coopératives agricoles en France. Aperçus sur une histoire séculaire", Économie rurale, v. 184, n. 1, p. 116-122, 1988.

${ }^{268}$ Méline ocupou os cargos de Ministro da Agricultura e Primeiro Ministro da França entre 1896 e 1898.

${ }^{269} C f$. MENDRAS, 1955, op. cit.; NICOLAS, 1988, op. cit.

${ }^{270}$ LAUNAY, Marcel. "Le clergé et la naissance des caisses rurales en Bretagne (1893-1914)". In: Annales de Bretagne et despays de l'Ouest. Presses Universitaires de Rennes, 1987, p. 553-564.
} 
tutela do Estado, como forma de aumentar a influência política dos republicanos no campo e de controlar o avanço das entidades aristocráticas.

Em 1893, Louis Durand organizou a Union des Caisses Rurales et Ouvrières de France, que funcionaria como cooperativa central das caixas de crédito organizadas por ele e que estavam ligadas a Union du Sud-Est. Em 1897, os republicanos aprovaram uma dotação para que a Banque de France dispusesse de um fundo de 40 milhões de francos para financiar as caisses regionales de credit agricole que fossem controladas pelo Estado. Contrariamente à intervenção do Estado francês, a SAF, por intermédio da Union Centrale passou a organizar as suas próprias caisses regionales de credit agricole mutuel que funcionariam como caixa central para articulação de suas caixas locais ${ }^{271}$. Enquanto isso, as caixas ligadas à Union des Caisses Rurales de Luis Douran mantinham sua independência em relação às caixas regionais mantidas pelo estado e pela SAF.

O desenvolvimento dos bancos populares urbanos tiveram desenvolvimento bem mais tímido na França. Assim, como na Alemanha, esse modelo se opunha ao caráter religioso e beneficente das caixas Raiffeisen. Um dos maiores divulgadores dos bancos populares na França era Ludovico de Besse, um frei capuchinho que possuía ideias liberais quanto à organização das cooperativas de crédito. Influenciado pelas instituições de Schulze-Delitzsch e pelos bancos de Luigi Luzzatti, que conheceu pessoalmente, Ludovico de Besse havia organizado diversos banco desse tipo desde a década de $1880^{272}$.

Em 1901, Ludovico de Besse, apesar de religioso, criticava o caráter confessional das caixas rurais de Louis Durand e da Caisse Centrale e das caixas regionais subsidiadas pelo Estado:

La caisse rurale n'est ni une oeuvre religieuse, ni une oeuvre politique. En effet elle n'est pas un sacrement, ni un service gouvernemental. Elle est une association économique. En conséquence nous avons condamné la doctrine qui fait de cette oeuvre une chose essentiellement religieuse ${ }^{273}$.

O sindicalismo e o associativismo rural de crédito de influência católica foi também muito forte na Bélgica, onde o partido católico mantinha o controle do governo. O sindicalismo-cooperativismo católico belga e o francês tiveram grande influência no Brasil, principalmente devido à aprovação da lei dos sindicatos agrícolas, em 1903, obtida

\footnotetext{
${ }^{271}$ NICOLAS, 1988, op. cit., p. 117.

${ }^{272}$ Idem, ibdem, p. 118.

${ }^{273}$ Ludovico de BESSE apud LAUNAY, 1987, op. cit., p. 554.
} 
depois de intensa campanha realizada pela Sociedade Nacional de Agricultura e também pela igreja católica, como veremos adiante.

O associativismo católico francês teve também grande influência em Portugal e Espanha, onde, entretanto, as caixas rurais não vicejaram com o mesmo sucesso da França e Bélgica.

Na Espanha, de acordo com Ángel Pascual Martinez Soto, o raiffeisianismo de matiz católico teve grande difusão a partir de 1891 devido à propaganda de Joaquim Diaz de Rábago, que mantinha correspondência com Louis Durand. A primeira experiência desse tipo ocorreu em Múrcia com a criação da Caja Rural de Ahorros, Prestamos y Socorros de Javalí Viejo, em $1891^{274}$. O número das caixas rurais espanholas creceu em ritmo mais lento, mas constante, chegando a 384 em 1910, porém, nos anos seguintes elas tiveram uma evolução muito lenta. Em 1924, havia 501 caixas rurais que contavam com 57.965 sócios.

O diminuto sucesso das caixas rurais na Espanha foi creditado pelo mesmo autor à sua dificuldade em levantar os recursos necessários de realizar operações de crédito. Apesar de que, em 1902, os sindicatos e as caixas rurais católicas chegaram a organizar um banco chamado Banco Popular de León XIII, que deveria centralizar as operações de suas caixas, mas que teve alcance bastante limitado. Em 1915, com o surgimento da Confederación Nacional Católica Agraria (CNCA), essa entidade, que tinha por objetivo organizar as corporações sociais católicas, tentou criar, em 1917, a sua própria instituição financeira, chamada Caixa de Crédito Confederal, mas que fracassou em menos de um ano por não conseguir atrair recursos ${ }^{275}$.

\subsection{Sindicalismo rural e cooperativas de crédito no Brasil}

A organização de sociedades mútuas para a provisão de crédito agrícola foi uma preocupação recorrente das lideranças agrárias e dos poderes federal e estaduais no Brasil, principalmente entre as décadas de 1890 e 1910. Nesse período houve uma intensa produção editorial voltada à propaganda do cooperativismo de crédito e este tema era

${ }^{274}$ MARTINEZ-SOTO, Ángel Pascual. "Los orígenes del cooperativismo de crédito agrario en España". CIRIEC-ESPAÑA, n. 44, p. 57-104, 2003.

${ }^{275}$ MARTÍNEZ-SOTO, Ángel P. e RODRÍGUEZ, Susana M. "Cooperativismo Agrario de Credito en Espana (1890-1935); Solidaridad Desde Abajo?" Segundo Congreso Latinoamericano de Historia Económica e Cuarto Congreso Internacional de la Asociación Mexicana de Historia Económica. Cidade do México, 2010. 
também recorrente na imprensa e foi abordado nos relatórios de diversos ministros da fazenda e na maioria dos relatórios dos secretários de fazenda de São Paulo, principalmente entre 1896 e 1918, assim como nas plataformas eleitorais de candidatos à presidência do estado, como Albuquerque Lins e Altino Arantes.

Analisando essas fontes verificamos a existência de pelo menos três vertentes do cooperativismo de crédito sendo difundidas no país. Uma delas é caracterizada pelo forte teor doutrinário raiffeisianista, marcadamente influenciada pelo catolicismo social, antissocialista e antiliberal. Outra vertente era inspirada no movimento agrarista francês, ainda que destituída de viés religioso, mantinha o caráter classista das associações francesas e belgas e estava relacionada ao movimento de constituição de sociedades agrícolas, como a Sociedade Nacional de Agricultura, e objetivavam criar espaços de convergência dos interesses agrários para exercer influência sobre as políticas estatais. Por outro lado, há uma absorção mais utilitária do cooperativismo calcada no reconhecimento da importância econômica das instituições associativas que haviam se difundido na Europa, tais como a caixa rural e o banco popular. Esta última vertente tinha uma interpretação liberal e via no associativismo de crédito uma forma de regularizar o crédito agrícola sem a intervenção do Estado.

Paralelamente a essas três vertentes é possível identificar alguns eixos principais pelos quais o cooperativismo de crédito se difundiu no país. Um deles foi associativismo adotado pela colônia católica alemã do Rio Grande do Sul, que buscou reproduzir instituições do movimento católico alemão e cuja liderança coubera ao padre jesuíta suíço Theodor Amstad e que fundou a primeira caixa rural do país na cidade de Nova Petrópolis, em 1902 1976 . Outro eixo de difusão do associativismo de crédito fora estabelecido entre a Sociedade Nacional da Agricultura, fundada no Rio de Janeiro em 1897 e associações de católicos leigos, que buscaram reproduzir no Brasil o modelo dos sindicatos agrícolas e caixas de crédito amplamente difundidos na Bélgica e na França. Esse segundo eixo fora responsável pela aprovação do Decreto n. 979, de 6 de janeiro de 1903 e pela organização de diversos sindicatos rurais em Minas Gerais, Pernambuco e Rio Grande do Sul. Finalmente, observamos um terceiro eixo, estabelecido principalmente entre São Paulo e Minas Gerais que tinha em comum uma interpretação mais utilitária a respeito do papel do cooperativismo e que culminaria na organização dos

${ }^{276}$ VOGT \& RADÜNZ, 2013, op. cit.. 
Bancos de Custeio Rural no interior paulista, a partir de 1903, e na política de incentivo às cooperativas cafeeiras promovida pelo governo, em 1907.

\subsection{O catolicismo social e seu papel na difusão do cooperativismo de crédito no Brasil}

O movimento, liderado pelo padre suíço Theodor Amstad, organizou diversos congressos católicos entre 1897 e 1900, e, no último deles foi criada a Associação RioGrandense de Agricultura, uma entidade de caráter multiconfessional, que deveria abranger católicos e luteranos alemães. Foi no âmbito dessa sociedade que surgiram as primeiras caixas rurais do país. A primeira delas foi a Caixa de Economia e Empréstimos, organizada em 1902 na localidade de Nova Petrópolis (posteriormente Caixa Rural de Nova Petrópolis) ${ }^{277}$ e a mais importante fora a Caixa de Economia e Empréstimos de Santa Cruz do Sul, posteriormente, Caixa Cooperativa de Crédito Santa-Cruzense (1904) ${ }^{278}$. Essa caixa obteve sucesso em atrair as poupanças da colônia alemã e chegou a manter filiais em diversas cidades do estado, mudando, posteriormente, sua dede para Porto Alegre e, em 1938, transformou-se no Banco Agrícola e Mercantil S/A.

Em 1912, durante o IX congresso católico realizado em Venâncio Aires, o movimento católico alemão resolveu criar uma nova sociedade, a Sociedade União Popular que existe ainda hoje. Essa entidade, de abrangência estadual, era composta por sessões formadas por entidades similares organizadas nos distritos municipais e chegou a contar com 9.000 sócios em 1914. Seu objetivo era atender tanto os interesses religiosos e culturais, como também os econômicos da comunidade alemã do estado, tendo organizado em 1925 a Central das Caixas Rurais da União Popular do Estado do Rio Grande do Sul, que por volta de 1933 contava com 34 caixas cooperativas filiadas ${ }^{279}$.

A maioria dessas associações de crédito faliu ou perdeu sua característica de cooperativas após a reforma bancária de 1964. De acordo com Gentil Corazza, a Central

277 Cf. OBERACKER JUNIOR, Carlos H, "Vestígios suíços na história do Brasil". Revista de História, São Paulo, v. XXXV, n. 72, p. 463-482, 1967, pp. 471-2; NORONHA, Andrius E, Beneméritos empresários: história social de uma elite de origem imigrante do sul do Brasil (Santa Cruz do Sul, 19051966), Porto Alegre, PUC-RS (Tese de Doutorado), 2012, pp. 278-294; SCHALLENBERGER, 2003, op. cit.

278 Esta caixa não era exatamente uma sociedade do tipo Raiffeisen, assemelhando-se aos bancos populares do tipo Schulze-Delitzsch, sendo composta por comerciantes e industriais alemães, tanto católicos como protestantes. $C f$. NORONHA, 2012, op. cit, pp. 278-294.

${ }^{279}$ VOLGT, 2013, op. cit. 
das Caixas Rurais faliu em 1967 e no mesmo ano o Banco Agrícola e Mercantil foi incorporado pelo banco Moreira Salles para formar o Unibanco ${ }^{280}$.

O eixo de difusão do cooperativismo de crédito desenvolveu-se em torno do movimento que Sônia Regina de Mendonça denominou de "ruralismo brasileiro", liderado principalmente por engenheiros da Escola Politécnica do Rio de Janeiro e intelectuais ligados à lavoura de Rio de Janeiro e Rio Grande do Sul que, em 1897, organizaram a Sociedade Nacional de Agricultura ${ }^{281}$, influenciada pelo agrarismo francês ${ }^{282}$.

A SNA, liderada por Assis Brasil, Wenceslao Bello e Joaquim Ignácio Tosta, empreendeu intensa campanha em prol do associativismo rural que levou à aprovação do Decreto n. 979, de 6 de janeiro de 1903 que regulamentava o estabelecimento de sindicatos rurais e caixas agrícolas no país. O modelo adotado era o da lei de liberdade sindical, aprovada na França em 1881283. Segundo a legislação francesa os sindicatos eram organizações estritamente profissionais, mas que podiam adquirir equipamentos e adubos para uso de seus sócios e atuar como institutos de previdência. Eles não podiam, entretanto, operar caixas de crédito nem realizar operações comerciais. Para realizar essas duas funções, eles organizavam, paralelamente, cooperativas de produção para comercializar seus produtos e caixas rurais para depósitos de poupança e financiamento de seus sócios. Enquanto isso, a lei brasileira de 1903 permitia aos sindicatos agrícolas operar como caixas rurais e também na comercialização de produtos agrícolas, o que mais tarde seria modificado pela aprovação do Decreto n. 1.637, de 5 de janeiro de 1907, que separava as esferas de funcionamento dos sindicatos e das sociedades cooperativas ${ }^{284}$.

Na sequência da aprovação da lei n. 979 surgiu um grande número de publicações a respeito do assunto, como o trabalho do conselheiro da SNA Carvalho Borges Junior,

${ }^{280} C f$. NORONHA, 2012, op. cit, pp. 278-294; CORAZZA, Gentil, "Sistema financeiro (e desenvolvimento) do Rio Grande do Sul", Ensaios FEE, Porto Alegre, v. 23, Número Especial, p. 491-516, 2002.

${ }^{281}$ Segundo Mendonça, a SNA estava comprometida com um projeto agrário independente da política hegemônica desenvolvida em torno da cafeicultura, buscando incentivar a diversificação da agricultura e a modernização das práticas de cultivo. $C f$. MENDONÇA, Sônia Regina de, "A Sociedade Nacional de Agricultura e a institucionalização de interesses agrários no Brasil", Revista do Mestrado em História (Universidade Severino Sombra), V. 2, 1999.

${ }^{282}$ MENDONÇA, Sonia Regina de, O Ruralismo Brasileiro: 1888-1931, São Paulo, Hucitec, 1997.

${ }^{283}$ Cf. LACOMBE, Américo Jacobina, “A igreja no início do século XX (1900-1910)”, In: Luiz Antônio Severo da COSTA, Brasil: 1900-1910. Rio de Janeiro: Biblioteca nacional, 1980, pp. 47-60; SILVA, Giovane José da, O batismo de clio: catolicismo-social e história em Jonathas Serrano (1908-1931), São João Del Rei: UFSJ (Dissertação de Mestrado), 2011.

${ }^{284}$ SOARES, José Julio, Idéas cooperatistas, Belo Horizonte, Salesiano, 1914. 
Propaganda Cooperativa ${ }^{285}$; Caixas Economicas e o Credito Agrícola de Alfredo Rocha (1905) ${ }^{286}$. Posteriormente, a SNA patrocinou a publicação de uma obra francesa sobre sindicatos agrícolas de Gailhard Bancelo, traduzida por João Batista de Castro com o título Manual Pratico dos Syndicatos Agrícolas ${ }^{287} e$ o Ministério da Agricultura publicou o trabalho de Wenceslao Bello, A Previdencia e o Credito Agrícola (1908); assim como a obra de Sarandy Raposo, funcionário do ministério que teve seu trabalho: Theoria e Pratica da Cooperação, publicado como anexo ao relatório de $1911^{288}$.

Recentemente, Giovani José da Silva, ao estudar a obra do militante católico Jonathas Serrano identificou ligações entre o projeto associativista da Sociedade Nacional de Agricultura com o movimento do catolicismo social, principalmente pelo seu vínculo com o Círculo Católico do Rio de Janeiro (CCRJ) e a União Católica Brasileira (UCB) ${ }^{289}$.

Ao estudar as obras de difusão do associativismo de crédito no Brasil, notamos também uma estreita relação entre a SNA e o Círculo Católico do Rio de Janeiro, principalmente pela atuação do deputado Joaquim Ignácio Tosta, autor da lei sobre sindicatos agrícolas e que compunha a direção da SNA e era membro do Círculo Católico do Rio de Janeiro. Tosta era fundador da Sociedade Baiana de Agricultura, entidade que presidiu o Congresso Canavieiro da Bahia (organizado pela SNA em 1901) e esteve também à frente do II Congresso Católico Brasileiro.

Outra convergência observada foi a realização quase simultânea do Congresso Católico e do II Congresso Nacional de Agricultura, realizados entre julho e agosto de 1908 e que contaram com a participação do belga Emilio Vlieberg, apontado como autoridade nos temas dos sindicatos agrícolas e das caixas rurais. Vlieberg era líder da Liga Democrática Belga e professor de economia rural da Universidade de Louvain $^{290}$ e

\footnotetext{
${ }^{285}$ Livro reúne o texto de sua conferência no $1^{\circ}$ Congresso Nacional de Agricultura, realizado em 9 de novembro de 1905, intitulado "Sobre o cooperativismo e a lavouar" e artigo publicado no Jornal do Comércio intitulado "Sobre a instictuição do syndicatos agrícolas".

${ }^{286}$ Alfredo Rocha era funcionário do Ministério da Indústria, Viação e Obras Públicas e membro da SNA, tendo também participado da comissão que organizou o II Congresso Nacional de Agricultura, Cf. Correio Paulistano, 31/8/1908, p.1.

${ }^{287}$ MOURA, 2013, p. 12.

${ }^{288}$ RAPOSO, C. A. Sarandy. "Theoria e pratica da cooperação (da cooperação em geral e especialmente no Brasil)". In: BRASIL. Relatorio apresentado ao presidente da República dos Estados Unidos do Brazil pelo Ministro do estado dos Negocios da Agricultura, Industria e Commercio, Dr. Pedro de Toledo, No anno de 1911 (v. III). Rio de Janeiro: Directoria Geral de estatística, 1911.

${ }^{289}$ SILVA, 2011, op. cit., p. 68.

290 Cf. A LAVOURA, XII, n. 1 e 2, 1908, pp. 4-7; DUARTE, A. Teixeira. Catecismo da Cooperação: O cooperativismo em Minas Gerais (1908-1911) - Seu histórico, suas practicas, seus resultados, Belo Horizonte: Beltrão \& Comp., 1912, pp. 9-19; SILVA, 2013, op. cit., p. 69-71.
} 
suas conferências proferidas nos congressos agrícola e católico versavam sobre política católica, sindicalismo e crédito agrícola. Elas foram publicadas, em 1910, como folhetim avulso da revista A Lavoura que era mantida pela SNA ${ }^{291}$. Segundo Américo Lacombe, a obra de Vlieberg sobre o sindicalismo agrário belga teria inspirado o projeto de Joaquim Ignácio Costa sobre sindicatos agrícolas em $1901^{292}$.

Em 1910, foi organizado o Centro Católico do Brasil, cuja assembleia de fundação fora convocada por Ignácio Tosta, Cândido Mendes de Almeida, Leôncio de Carvalho (membro da SNA em São Paulo e primeiro presidente da Sociedade Paulista de Agricultura) e Lucio José dos Santos, delegado da diocese de Mariana e difusor do raiffeisianismo em Minas Gerais, autor do livro Ao Povo Mineiro: As Caixas Agrarias do Systema Raiffeisen (1911). O Centro Católico deveria atuar como um partido político, a exemplo do Centro Católico Alemão: segundo o discurso de Plácido de Mello, o Centro seria núcleo organizador de um partido nacional, com sede na cidade do Rio de Janeiro, destinado a concentrar a direção política dos católicos brasileiros ${ }^{293}$. Plácido de Mello fez uma ampla explanação sobre as caixas rurais do modelo Raiffeisen, reivindicando aos católicos e, principalmente, à orientação do Papa Leão XIII o seu sucesso:

A caixa rural ou cooperativa do sistema raiffeisen, senhores, é a aplicação prática da encíclica 'Rerum Novarum' nos domínios da atividade agrícola, onde, como sabeis, moureja a grande maioria dos nossos compatriotas.

É uma obra católica não porque seja obra confessional, mas porque se baseia no credito pessoal. Não há credito pessoal sem moralidade, nem moralidade sem religião, bem entendido, sem religião católica, que é a única religião verdadeira. Raiffeisen não conseguiu fazer medrar sua instituição entre protestantes; daí provavelmente a sua conversão ao catolicismo ${ }^{294}$.

O Centro Católico incentivou a publicação de várias obras a respeito das caixas Raiffeisen, como o trabalho de José Júlio Soares, citado anteriormente, o trabalho de Teixeira Duarte Catecismo da Cooperação: O cooperativismo em Minas Gerais (1908-

\footnotetext{
291 As conferências de Vlieberg versavam sobre os seguintes temas: I. Os católicos belgas: o que tem contribuído para a sua permanência no poder há vinte e quatro anos; II. Os congressos anuais dos Católicos alemães; III. As tendências dos povos latinos e germanos na solução da questão social; IV. Das obras agrícolas da Bélgica; V. Do crédito agrícola; VI. Seguro contra moléstia; VII. Seguro contra invalidez e a velhice; VIII. Seguro contra a falta de trabalho. Cf. SILVA, 2013, op. cit., p. 71

${ }^{292}$ Cf. LACOMBE, 1980, op. cit., pp. 47-60.

${ }^{293}$ O Paiz, 5/11/1912.

${ }^{294} C f$. Conferência de Plácido de Mello perante o Círculo Católico do Rio de Janeiro, em O Paiz, 5/11/1912.
} 
1911) - Seu histórico, suas practicas, seus resultados (1912), além da obra de Plácido de Mello, O Evangelho em Ação Social - Caixas Rurais (1913) ${ }^{295}$.

Se a defesa do sindicalismo agrícola e das caixas Raiffeisen aproximava a Sociedade Nacional de Agricultura do Círculo Católico do Rio de Janeiro na década de 1900, na década seguinte parece ter havido um distanciamento entre elas, pois, em 1913, Plácido de Mello defendia a criação de uma liga agrícola católica. Ele se justificava dizendo que se a lei sindical era cristã, cristã haveria de ser a Liga dos lavradores ${ }^{296}$. Nas propostas de organização de caixas rurais e bancos populares em São Paulo, não se observa nem a vinculação entre sindicato e cooperativa, característico do modelo francês, seguido pela Sociedade Nacional de Agricultura, tão pouco se observa uma forte tendência doutrinária.

\subsection{O cooperativismo de crédito em São Paulo}

Em São Paulo, o interesse pelas cooperativas de crédito resultava do reconhecimento da importância desses pequenos bancos dentro do sistema de crédito em países como Alemanha, Itália e França, países onde o sistema bancário não fora capaz de difundir suas instituições pelas zonas mais remotas, tal como se observava com os pequenos bancos provinciais e locais existentes na Inglaterra, Escócia e nos EUA.

A adoção do cooperativismo de crédito era defendida pela sua alegada capacidade em suprir uma carência do sistema bancário paulista, concentrado na capital do estado. Após a abolição, os poderes econômicos do estado viam como urgente a necessidade de se incentivar a constituição de bancos regionais e caixas econômicas no interior do estado, que recuperassem os recursos utilizados para o pagamento dos colonos e restituí-los à circulação. Durante as décadas de 1890 e 1900 acreditava-se que havia uma imensa quantidade de recursos monetários que os colonos guardavam em casa, na expectativa de enviar para Europa assim que o câmbio fosse favorável. Desse modo, a constituição de caixas econômicas e cooperativas de crédito nas localidades permitiria aos colonos guardar esses recursos de maneira segura e contribuindo para a dinamização do sistema de crédito.

\footnotetext{
295 MOURA, Valdiki, Bibliografia brasileira do cooperativismo: pequeno ensaio de sistematização. Rio de Janeiro: Casa do Estudante do Brasil, 1951.

${ }^{296}$ SILVA, 2013, op. cit., p. 71.
} 
Foi com base nessa nova característica da circulação monetária ocasionada pelo trabalho livre que Rui Barbosa, em 1890, justificava a necessidade de se elevar o volume das emissões monetárias:

E eis como a extinção da propriedade servil constituiu, por assim dizer, e generalizou a circulação monetária, quase nula, até então, nas zonas agrícolas e lenta, muito lenta mesmo, no seio das aglomerações urbanas, onde ainda hoje prepondera o habito de amealharem-se em casa os frutos da economia particular, e somas incalculáveis, que noutros países se confiam aos bancos, penetrando por estes no movimento geral da circulação, dormem aqui preciosamente estagnadas na gaveta, ou na algibeira individual ${ }^{297}$.

Para Rui Barbosa, a resolução para tal problema passava, primeiramente, pelo aumento da circulação monetária, calculando que ela deveria ser elevada em 505\%, e, secundariamente pelo incentivo à poupança.

Em São Paulo, onde diversos documentos apontam que o volume de crédito consumido pelo custeio das fazendas superava 100 mil contos de réis anualmente, a preocupação com a captação da poupança dos colonos se reflete na crítica à legislação federal centralizadora a respeito das caixas econômicas, na tentativa de se estabelecer uma caixa econômica estadual, cuja primeira tentativa ocorreu em 1893 e na denominação de diversos bancos comerciais que surgiram no interior do estado, tais como Banco Popular de Guaratinguetá, Banco Regional de Mocóca, Banco União de São Carlos, e mesmo no Banco Popular e Banco Cooperativo. Quando da constituição do Banco Comércio e Indústria de São Paulo, em 1889, seus estatutos previam a existência de uma seção especial, responsável pela organização de bancos populares, o que não foi concretizado.

Ao problema da destinação das economias dos trabalhadores e pequenos industriais e comerciantes, após 1896, somara-se a percepção de que o atual modelo de financiamento da cafeicultura, baseado no comissário de café era limitado. Diante do descontentamento dos fazendeiros e as insistentes reivindicações para que o governo estadual criasse ou subsidiasse os bancos agrícolas, o incentivo à criação de cooperativas de crédito era apresentado como uma solução para o problema do crédito sem que fosse necessário ao Estado atuar diretamente na formação de bancos agrícolas.

Em 1896, o ministro da fazenda, o paulista Bernardino de Campos fez uma extensa exposição sobre os benefícios das caixas rurais e bancos populares como forma de resolver o problema da crise da lavoura. Ele refutava qualquer possibilidade de o

${ }^{297}$ BARBOSA, 1949, op. cit., p. 147. 
Estado vir a subsidiar ou mesmo organizar bancos agrícolas, defendendo, em contrapartida, a adoção de um modelo de financiamento "paralelo" ao mercado de crédito e que, ao mesmo tempo, fosse independente do Estado. $\mathrm{O}$ ministro discorreu longamente sobre o crédito agrícola na Europa e demonstrou que, exceto na Inglaterra e na Escócia, os bancos tradicionais também não emprestavam à lavoura. Como consequência, em países como França, Alemanha, Itália e Bélgica haviam se formado extensas redes de caixas rurais e bancos populares modeladas nos princípios das caixas Raiffeisen e Schulze-Delitzsch (na Alemanha) e dos bancos Luzzatti (na Itália) ${ }^{298}$.

Bernardino de Campos propunha que os fazendeiros brasileiros deveriam seguir o exemplo dos povos mais adiantados e organizar cooperativas de crédito que pudessem captar os depósitos na sua zona de atuação e, munidos dessa poupança, e de empréstimos levantados com a rede bancária, pudessem prover mutuamente os adiantamentos de que necessitavam.

Em 1891, o deputado paulista, Paulo Egydio, um dos fundadores do Banco Comercial e Agrícola de São Paulo, publicou na imprensa paulista ensaios sobre sociedades cooperativas e sobre caixas econômicas que foram publicados posteriormente com o título Ensaio Sobre Algumas Questões de Direito e Economia Política ${ }^{299}$. Em 1900, Antônio de Lacerda Franco, diretor do Banco União de São Paulo, publicou o livro Estudos Sobre a Aplicação da Mutualidade ao Crédito Rural e Agrícola no Brasil.

Paralelamente, no âmbito das reuniões dos clubes da lavoura para a organização do Centro da Lavoura do Estado de São Paulo, surgiram também diversas projetos sobre caixas rurais, destacando-se a participação de Symphoroso de Lara Fernandes, Jacintho Ferreira da Silva Barros e Domingos Jaguaribe. Symphoroso de Lara era membro do Clube da Lavoura de Batatais, reduto oposicionista, onde atuavam Washington Luiz, Altino Arantes e Albuquerque Lins. Foi na gestão deste último na Secretaria da Agricultura que se organizaram os Bancos de Custeio Rural. Em 1906, Symphoroso de Lara Fernandes foi contratado pela Secretaria de Agricultura para organizar cooperativas

\footnotetext{
${ }^{298}$ BRASIL, Ministério da Fazenda, Relatório apresentado [...] pelo Ministro de Negocios da Fazenda Bernardino de Campos, no anno de 1897, Rio de Janeiro: Imp. Nacional, 1897 p. 180-210.

${ }^{299}$ EGYDIO DE CARVALHO, Paulo, Ensaio sobre algumas questões de direito e economia politica. São Paulo: J. G. d’Arruda Leite, 1896.
} 
leiteiras no estado e, sob os auspícios da Sociedade Paulista de Agricultura, publicou o livro Syndicatos Agricolas (1906) ${ }^{300}$.

Em que pese à legislação brasileira sobre cooperativas agrícolas ter assimilado o vínculo entre as associações sindicais dos fazendeiros e a organização de caixas rurais, esse arranjo foi logo desestimulado em São Paulo. Foi adotado no estado um modelo de cooperativas que assimilava de maneira utilitária o raiffeisianismo alemão e o associativismo agrário francês; o que se explicava pelo receio de que o crescente descontentamento dos fazendeiros desencadeasse uma rebelião eleitoral contra o Partido Republicano Paulista. Desse modo, o governo paulista e a direção do PRP buscaram desestimular a organização de associações de fazendeiros, tal como fez com a Associação dos Agricultores Paulistas (1896) e a cooptação das lideranças do Centro dos Lavradores do Estado de São Paulo (1900), incentivando a organização de uma associação rural de caráter governista que congregava os interesses do estrato superior dos fazendeiros, a Sociedade Paulista de Agricultura, que foi fundada em 1902.

A organização de caixas rurais foi totalmente desatrelada das associações sindicais, em que pese à lei 866 de 1903, que havia determinado a concessão de um auxílio aos sindicatos e cooperativas que operassem caixas rurais, os Bancos de Custeio Rural estavam organizados como sociedades anônimas e eram totalmente destituídos de caráter sindical, constituindo-se em associações de crédito de caráter puramente econômico e que mais se aproximavam dos bancos populares alemães do tipo Schulze-Delitsch e os Luzzati da Itália, que das darlenkassen e caisses rurales do modelo Raiffeisen, tradicionalmente utilizadas na agricultura.

${ }^{300}$ FERNANDES, Symphoroso de Lara, Syndicatos agricolas: notas à lei n. 979, de 6 de janeiro de 1903, São Paulo: Rothschild, 1906. 


\section{Os Bancos de Custeio RuRal}

\subsection{A trajetória do projeto idealizado por Jacintho de Barros em 1899}

Vimos anteriormente o desenvolvimento de dois debates que se entrecruzaram no período entre 1896 e 1906. O primeiro deles referente à organização de instituições de crédito agrícola e o segundo, resultado das discussões em torno organização de associações de classe de fazendeiros em São Paulo. Demonstramos como os debates em torno dos problemas agrários no Brasil estiveram influenciados pelas experiências europeias, principalmente a francesa, em que os interesses agrários encontraram na formação de associações, sindicatos agrícolas e cooperativas de crédito um modo de satisfazer as necessidades de modernização e de financiamento da agricultura naquela quadra de crise. Esse modelo de mobilização social e organização dos interesses políticos e econômicos foi reproduzido em formas diversas no Brasil. Em São Paulo, o cooperativismo de crédito foi implementado com auxílio do Estado na sequência das negociações em torno do plano de valorização do café e culminou na organização da Sociedade Paulista de Agricultura e dos Bancos de Custeio Rural.

Em 1899, Jacintho Pereira da Silva Barros, um proprietário de terras oriundo da região de Taubaté, no Vale do Paraíba, e que atuava como advogado e fazendeiro no município de Jaboticabal, organizou uma cooperativa de crédito denominada Caixa Agrícola de Jaboticabal ${ }^{301}$. Barros era membro do Clube da Lavoura de Jaboticabal e delegado dessa agremiação na assembleia de fundação do Centro dos Lavradores do Estado de São Paulo, consequentemente, era também aderente ao Partido da Lavoura. Ele enviou ao governo paulista um pedido de auxílio a seu banco cooperativo e teve sua petição respondida no relatório da Secretaria da Fazenda de 1900, que afirmou o seguinte:

Os estatutos dessa sociedade eram vasados em moldes elevados, moralizadores, contendo elementos que se aproximavam de outros países, sistema em que a par da iniciativa dos interessados, dominam o limite do voto e o das exigências e ambições dos que fazem parte da associação ${ }^{302}$.

Esse primeiro experimento não vingou, segundo Jacintho de Barros, porque ele deixou de ser fazendeiro naquela cidade para assumir o cargo de juiz municipal em

\footnotetext{
301 Correio Paulistano, 17/11/1907, p. 2 - "Bancos de Custeio Rural".

302 SÃO PAULO. SECRETARIA DA FAZENDA. Relatorio Apresentado ao Dr. Francisco de Paula Rodrigues Alves, Presidente do Estado, Pelo Dr. Francisco de Toledo Malta, Secretario da Fazenda, Anno de 1900. São Paulo: Typ. Do Diario Official, 1901, p. 45.
} 
Capivari $^{303}$, porém, segundo o secretário da Fazenda, o motivo do insucesso fora a baixa adesão dos fazendeiros da localidade devido provavelmente as dificuldades da quadra difícil para a reunião de capitais $^{304}$.

Consoante o pensamento do ministro da Fazenda em 1896, Bernardino de Campos, Jacintho de Barros entendia que o crédito agrícola deveria se estabelecer por meio de associações dos próprios fazendeiros, em circunscrições limitadas, cabendo ao governo auxiliar a iniciativa particular apenas no seu início ${ }^{305}$. Preocupando sempre em deixar claro que esse auxílio não era subsídio, apenas um impulso para que, associados, os próprios fazendeiros tratassem de canalizar o capital para o custeio da lavoura.

Já Francisco Malta, o secretário da Fazenda, era partidário das ideias de Joaquim Murtinho e denunciava as reivindicações dos fazendeiros por crédito agrícola como auxílios artificiais que apenas poderiam beneficiar aos produtores marginais. Malta, entretanto, apoiava a organização de cooperativas como meio legítimo de estabelecer o crédito agrícola, desde que partisse da iniciativa particular, que deveria se constituir como uma alternativa às subvenções a bancos agrícolas.

É por meio dessa assimilação liberal das políticas de crédito agrícola que o cooperativismo é adotado em São Paulo. A constituição dos Bancos de Custeio Rural é fruto dessa resistência ao intervencionismo e do empenho particular de Jacintho de Barros que, desde 1899 até 1906, organizou várias caixas rurais que serviriam de modelo à propaganda do cooperativista no estado. Em 1903, ele organizou o Banco de Custeio Rural de Capivari e o de Ribeirão Bonito e defendeu sua proposta em diversas reuniões e congressos de lavradores em Campinas e Ribeirão Preto.

Outra proposta de cooperativa fora apresentada em uma Sessão Extraordinária do Congresso Legislativo de 1903, por meio de uma petição encaminhada pela recém-criada União dos Lavradores de São Paulo, entidade que se apresentava como Syndicato Agricola Central e seus organizadores a apresentavam como sendo moldada pela lei dos sindicatos rurais aprovada recentemente e argumentavam que o governo paulista deveria tomar o exemplo do governo francês e incentivar a proliferação de tais instituições: indubitável que, no seio dos Syndicatos Agrícolas, encontrarão os lavradores a melhor defesa de seus interesses, pela valorização de seus produtos e reorganização de seu

${ }^{303}$ SÃO PAULO. ALESP: ACERVO HISTÓRICO. Parecer n. 125 de 1903, cx 226, pp. 9-26

${ }^{304}$ Idem, p. 46

305 idem, p. 9 - "Introdução" 
crédito. Nesse sentido, afirmava que a aprovação da lei n. 979 vinha satisfazer uma aspiração perfeitamente justificável, mas que, no entanto, o espírito associativo não está ainda perfeitamente orientado entre nós e, sendo assim, solicitava auxílios ao governo estadual $^{306}$.

A União dos Lavradores se propunha a atuar como sindicato central para a comercialização do café produzido por fazendeiros organizados em torno de sindicatos locais que, por sua vez, estariam filiados à União dos Lavradores. O financiamento dos produtores associados seria provisionado por caixas rurais, anexas aos sindicatos locais, tal como nas instituições francesas, e teriam os recursos centralizados pela União dos Lavradores que funcionaria como caixa central. Seus organizadores solicitavam isenção do imposto de exportação e redução de $30 \%$ das tarifas ferroviárias. Não sabemos quando essa sociedade foi criada, mas logo após a aprovação da lei dos sindicatos agrícolas foi convocada uma assembleia para adequar seus estatutos à nova legislação. Seus diretores no fim de 1902 eram Octaviano Vallim Pereira de Souza, Barão de Almeida Vallim, Higino Costa, Alvaro Teixeira Pinto e Domingos José Nogueira Jaguaribe ${ }^{307}$. Desde 11 de dezembro de 1902, essa sociedade mantinha em circulação um boletim semanal chamado União dos Lavradores: Órgão da União dos Lavradores de São Paulo, que tinha Jaguaribe como redator ${ }^{308}$.

Domingos Jaguaribe havia defendido a organização de sindicatos rurais para venda do café de seus associados no Congresso de Lavradores, que ocorreu na Capital em 1903, em que o congresso foi composto por monarquistas e presidido pelo barão Geraldo Rezende. Constatamos que esse congresso fora oficialmente convocado pela própria Sociedade União dos Lavradores, demonstrando que muito mais que uma cooperativa agrícola, seus organizadores tinham a pretensão de fazê-la funcionar como órgão de classe ${ }^{309}$.

A proposta de auxílio aos sindicatos filiados fora encaminhada ao governo paulista e acabou sendo inserida na lei $\mathrm{n}^{\circ} 866$ de 1903, cujo texto autorizava o governo a

\footnotetext{
${ }^{306}$ SÃO PAULO. ALESP: ACERVO HISTÓRICO. Projeto n. 40, de 1903, cx 60 - "União dos Lavradores de São Paulo" [petição], pp. 84-6.

307 Correio Paulistano, 1903.01.25, p.1, "Acta de assemblea geral da Sociedade União dos Lavradores de S. Paulo".

308 MARTINS, Ana Luiza, Revistas em Revista: Imprensa e Práticas Culturais em Tempos de República, São Paulo (1890-1922), São Paulo: Edusp, 2001, p. 295.

309 Correio Paulistano, 1903.02.04, p. 1, "Congresso dos lavradores - Sessão de 3 de fevereiro Presidencia do sr. Barão de Rezende".
} 
auxiliar a fundação de sindicatos e cooperativas agrícolas e autorizava o governo a fornecer-lhe 25 mil contos de reis para conceder adiantamentos a seus sócios assim como por meio de um banco agrícola que se pretendia organizar ${ }^{310}$. A Sociedade União dos Lavradores chegou a exportar o café, mas não recebeu os auxílios autorizados pelo Congresso Legislativo e logo em seguida faliu.

Percebe-se aqui a influência das associações de classe dos agricultores franceses nos arranjos encontrados para organizar cooperativas de crédito no Brasil. A Sociedade União dos Lavradores estava em sintonia com as associações propagadas pela Sociedade Nacional de Agricultura e que culminariam na aprovação na lei de sindicatos agrícolas de 1903. Percebe-se por conta disso o vínculo estreito entre as associações de crédito planejadas e as sociedades de caráter de classe, o que, naquele contexto político acirrado, costumavam a evoluir para a contestação partidária. No caso do congresso de fevereiro de 1903, embora possamos perceber a presença marcante de monarquistas, o clima era de conciliação com o governo e o PRP.

Veremos a seguir que a concepção de caixa rural idealizada por Jacintho de Barros foge completamente à lógica classista das caixas rurais ligadas às associações de agricultores franceses e às associações propagadas pela SNA. Seu projeto, apesar de inspirado diretamente nas caixas do tipo Raiffeisen, tinha em comum com elas a gratuidade dos serviços da diretoria, a limitação geográfica e a atuação exclusiva ao âmbito rural. Porém, os Bancos de Custeio Rural assumiriam muitas das características dos bancos populares, negando-lhes o papel beneficente assim como o caráter moralista e religioso, do mesmo modo, estavam desvinculadas das associações de classe, o lucro também não era condenado, mas apenas limitado a $6 \%$.

Após a aprovação da Lei 866, Jacintho de Barros, que agora residia em Capivari e atuava como juiz municipal, organizou com auxílio do poder político local o Banco de Custeio Rural de Capivari, cuja ata de fundação data de 16 de julho de $1903^{311}$. Em 20 de agosto de 1903, ele peticionou ao Congresso Legislativo, solicitando um empréstimo de 800 contos de réis, na verdade, ele requeria a emissão de apólices da dívida pública e o

310 Lei n. 866, de 7 de abril de 1903, "Providencia sobre os meios de attenuar os effeitos da crise da lavoura de café".

${ }^{311}$ SÃO PAULO. ALESP: ACERVO HISTÓRICO. Parecer n. 125 de 1903, cx 226 - Gazeta de Capivary, 19/09/1903, "Estatutos do Banco de Custeio Rural de Capivary". 
seu empréstimo às caixas de crédito que se organizassem segundo o modelo do banco de Capivari $^{312}$.

Muito embora o Banco de Custeio Rural de Capivari fosse organizado como sociedade anônima ele deveria atuar como uma cooperativa de crédito restrita ao âmbito dos fazendeiros, seus estatutos não faziam qualquer referência aos sindicatos agrícolas e a lei foi aprovada em janeiro daquele ano; também não fora reivindicado os auxílios preconizados pela Lei n. 866, que apenas recairiam sobre as caixas organizadas como sindicatos.

Segundo a ata de fundação do Banco de Custeio Rural de Capivari, apenas dois dos diretores se identificaram como fazendeiros, Theophilo Olyntho de Arruda e Francisco de Paula Penteado, ambos plantadores de cana-de-açúcar. Os demais eram um comerciante, José Dias Ferraz; o próprio Jancintho Pereira da Silva Barros (advogado); o padre Manoel José Marques (ex-presidente da Câmara Municipal) e o promotor público e, posteriormente, juiz de Direito Agrícola de Campos Salles ${ }^{313}$. Em seu discurso de encerramento da assembleia inaugural, Jacintho de Barros mencionou o apoio de diversas personalidades políticas, o que nos ofereceu algumas pistas sobre sua filiação política, tais como Augusto Ramos, Albuquerque Lins, Jorge Tibiriçá, João Ribeiro Marcondes (capitalista), Antônio Dino da Costa Bueno, Pedro Lessa, Siqueira Campos, Veiga Filho, Ismael Dias da Silva e Antônio Lobo. Com exceção de Jorge Tibiriçá, todos esses homens haviam participado de dissidências ou do lançamento de partidos de oposição ao PRP nos últimos anos, a maioria deles estava na organização do Centro dos Lavradores do Estado de São Paulo.

No pronunciamento de encerramento da assembleia constituinte, Barros manifestou o objetivo de fazer com que o banco servisse de modelo aos demais que lhe seguiriam, devendo ser organizados nos principais centros cafeeiros e convergindo para uma federação de cooperativas de crédito que acumulasse forças suficientes para livrar seus associados da dependência em relação ao crédito fornecido por comissários e prestamistas.

312 Idem, "Petição de Jacintho Pereira da Silva Barros, solicitando um auxilio para o Banco de Custeio Rural de Capivary" (documento anexado ao parecer 125).

${ }^{313}$ Idem, ibdem. 
Em 2 de outubro de 1903, Jacintho de Barros participou da organização do Banco de Custeio Rural de Ribeirão Bonito ${ }^{314}$ que, diferentemente do Banco de Capivari, estava situado em um importante centro produtor de café, próximo a São Carlos.

Era pretendido que o Congresso Legislativo autorizasse a emissão de oitocentas apólices de um conto de réis a serem emprestadas pelo tesouro estadual aos primeiros bancos de custeio criados. Uma vez que as apólices estivessem em poder dos bancos, elas seriam utilizadas como garantia em empréstimos levantados à rede bancária da capital que, por sua vez, seriam aplicados em empréstimos aos fazendeiros associados com juros de no máximo $8 \%$ ao ano ${ }^{315}$.

De acordo com sua argumentação, o auxílio pretendido não acarretava ônus para o Estado, porque não se tratava do empréstimo de dinheiro, mas de apólices que apenas se transformariam em compromisso de pagamento, caso falissem aqueles bancos, tratarse-ia de um voto de confiança. A hipótese de falência deveria ser descartada porque o modelo mútuo e o fato dos empréstimos serem garantidos pelo penhor agrícola confeririam uma solidez plena a esses bancos. No entanto, em resposta à petição de Jacintho de Barros, a Comissão de Fazenda e Contas emitiu um parecer desfavorável em 9 de outubro. A Comissão reconhecia a manifesta utilidade de tais bancos, mas negava o auxílio justificando que como era intentado operar sob o lastro garantidor das apólices do Estado seria o Estado quem, afinal de contas, responderá pelo insucesso do novo tipo bancário, hipótese que não pode ser gratuita $^{316}$. Por outro lado, o relator concluía o seu parecer dizendo que não cabia ao Congresso discutir uma nova lei de auxílio agrícola enquanto estava em vigor a lei n. 866 que já havia autorizado o governo a auxiliar a fundação de sindicatos e cooperativas agrícolas ${ }^{317}$.

A Comissão de Fazenda e Contas era composta por Uladislau Herculano de Freitas, João Pedro da Veiga Filho (relator) e Antônio Mercado, apenas este último votou

314 Diario Official do Estado de São Paulo, 12/5/1907, p. 1445 - Acta da assembleia extraordinaria do Banco de Custeio Rural de Ribeirão Bonito, em 14 de Abril de 1907.

${ }^{315}$ Idem, "Petição de Jacintho Pereira da Silva Barros, solicitando um auxílio para o Banco de Custeio Rural de Capivary" (documento anexado ao parecer 125), pp. 5-8.

316 SÃO PAULO. ALESP: ACERVO HISTÓRICO. Parecer n. 125 de 1903, cx 226.

${ }^{317}$ Idem, ibdem., p. 2. 
contrariamente ao parecer, e resolveu transformar a petição de Jacintho de Barros em um projeto de lei: projeto n. 40 de $1903^{318}$.

Jacintho de Barros havia anexado à petição um estudo com o título Modelos de estatutos para Bancos de Custeio Rural, composto por um estatuto modelo que serviria de base aos demais bancos de custeio e uma exposição de motivos. Fora também anexada uma carta de recomendação escrita por Augusto Ferreira Ramos, avalizando a necessidade e a viabilidade do plano. Ramos era engenheiro, formado pela Escola Politécnica do Rio de Janeiro e também fazendeiro e havia atuado na organização do Centro dos Lavradores do Estado de São Paulo e, em 1902, aderiu ao governo e ajudou a fundar a Sociedade Paulista de Agricultura ${ }^{319}$.

Na exposição de motivos, Barros dizia que a crise da lavoura seria resolvida tomando como lição as medidas aplicadas nos países europeus. Estes, ao passarem pela mesma situação, incentivaram a criação de bancos agrícolas e caixas de crédito para prover e auxiliar a lavoura. Dizia ainda que no Brasil a missão das cooperativas seria facilitada pela poupança que os colonos traziam acumulada em suas casas e que não confiavam em depositar nos bancos tradicionais. Os Bancos de Custeio, por sua vez, deveriam conquistar a confiança dos colonos, confiando-lhe o depósito de suas economias, fazendo voltar à circulação, uma parte ao menos, desse imenso capital em que consigo retém, e cuja falta tantas perturbações nos está causando ${ }^{320}$.

O projeto de Jacintho de Barros encerrava também uma interpretação a respeito da natureza da crise, em sua opinião, ela não tinha causa na superprodução, nem por falta de numerário, tratava-se unicamente de uma crise financeira, apenas conjuntural, resultado de uma passageira falta de confiança:

O dinheiro empregado se reproduz anualmente e o juro comum é suportável; só para o custeio, incontestavelmente, existem utilizáveis reservas mais que

${ }^{318}$ SÃO PAULO. ALESP: ACERVO HISTÓRICO. Parecer 141 de 1906, cx. 229, p. 4.

${ }^{319}$ Segundo Thomas Holloway, Augusto Ramos foi o idealizador da medida de taxação dos novos cultivos de café aplicada em 1902 e, mais tarde, entre o fim de 1904 e o início de 1905 visitou os principais países produtores de café da América Latina para conhecer o estado da produção no estrangeiro. No relatório dessa viagem, Ramos afirmou que aqueles países não ofereceriam risco à posição de quase monopólio do Brasil; este texto seria utilizado para justificar a viabilidade da intervenção no mercado. No final de 1905, Ramos foi também o chefe da delegação paulista que negociou com os representantes de outros estados o plano de valorização, firmado mais tarde em Taubaté entre os presidentes dos estados produtores. $C f$. HOLLOWAY, op. cit., pp. 53-59.

${ }^{320}$ SÃO PAULO. ALESP: ACERVO HISTÓRICO. Parecer $n .125$ de 1903, cx 226, p. 15. 
suficientes, em numerário imobilizado no interior, especialmente em poder de colonos, e também aqui nas caixas dos bancos de depósito ${ }^{321}$.

Desse modo, percebemos aqui como a proposta do crédito cooperativo representava uma alternativa às propostas existentes que visavam à emissão de moeda e à subvenção a bancos agrícolas, admitindo-se, por outro lado, a deficiência no sistema de crédito em suprir de crédito a lavoura, o que deveria ser sanado pela iniciativa dos próprios fazendeiros, sem a intervenção do tesouro federal ou estadual.

Tais bancos somente emprestariam a seus sócios o valor que fosse estritamente necessário ao custeio de suas fazendas pelo período de um ano, sob a garantia do penhor da safra ${ }^{322}$. A segurança de tais instituições estaria garantida pelo duplo papel que o sócio cumpre em uma sociedade de cunho mutualista: a verdadeira vitalidade dos Bancos de Custeio Rural está na harmonia do interesse de todos em sustentá-los pela identificação do duplo caráter de acionista e mutuário na mesma pessoa ${ }^{323}$. Cada sócio teria interesse em manter seus pagamentos e fiscalizar a pontualidade dos demais: na qualidade de acionistas, são garantes das transações e na qualidade de mutuários, tem todo o interesse em que os excessos dos juros pagos [...] não se percam em cobrir prejuízos dados por $u m^{324}$.

O valor dos empréstimos deveria ser estabelecido com base em uma avaliação dos custos da produção anual do mutuário, evitando que o dinheiro fosse utilizado para outros fins. Além disso, os empréstimos não poderiam exceder em seis vezes o valor nominal de cada ação até o máximo de seis ações por sócio, de modo que uma única pessoa não devesse quantia alta demais em relação à sua participação no capital da instituição.

Por outro lado, os estatutos desses bancos limitavam o poder dos sócios e a remuneração das ações, aproximando-os das cooperativas de crédito do tipo Raiffeisen. Cada sócio teria direito a um único voto, independentemente do número de ações que ele possuísse, assim, impedia-se que um indivíduo pudesse concentrar o controle da instituição, desfavorecendo os demais acionistas. Enquanto nas caixas Raiffeisen, o lucro

\footnotetext{
${ }^{321}$ Idem, ibdem, p. 9 (carta de Augusto Ramos anexada ao parecer 125)

${ }^{322}$ Idem, ibdem, p. 10.

${ }^{323}$ Idem, ibdem.

${ }^{324}$ Idem, ibdem, p. 11.
} 
era suprimido pelo desconto dos juros a pagar, nos bancos de custeio o dividendo era limitado em $6 \%$ ao ano.

\subsection{O surgimento da Sociedade Incorporadora e a aprovação da lei 1.062 em 1906}

No ano 1906, a crise econômica e a crise política haviam se intensificado. Os ânimos se encontravam ainda mais acirrados que em 1903 e 1904. Na primavera de 1905, uma florada abundante nos cafezais prenunciava a ocorrência de uma "safra monstro", como se dizia. Tais prognósticos alarmaram de tal modo fazendeiros, comerciantes e o governo paulista que os últimos entraves à intervenção no mercado cafeeiro foram removidos. Em fevereiro de 1906, firmara-se o Convênio de Taubaté, entretanto, o plano de valorização só entraria em vigor após a posse do presidente Afonso Pena; nesse interim, ocorria um acirrado debate em torno do tema da valorização no Congresso Legislativo de São Paulo e, paralelamente, colocava-se em prática, finalmente, aquelas medidas anunciadas pela lei n. 866, de 1903, que, além de haver autorizado a realização do convênio, permitia que o governo contratasse a incorporação de um banco agrícola e auxiliasse a criação de cooperativas de crédito, de acordo com a lei de sindicatos agrícolas daquele mesmo ano ${ }^{325}$.

A incorporação de um banco hipotecário agrícola foi possibilitada depois que o governo paulista assinou o contrato com um pool de capitalistas franceses para criação do Banco de Crédito Hipotecário e Agrícola do Estado de São Paulo, que entraria em operação em 1909. No que dizia respeito às caixas rurais, a proposta inicial avalizada por Bernardino de Campos e prevista na Lei n. 866, que consistia na criação de sindicatos agrícolas regidos pelo Decreto n. 979, de 6 de janeiro daquele ano, foi substituída pelo

${ }^{325} \mathrm{O}$ plano Siciliano era uma versão mais adequada aos interesses da trust teuto-norte-americano que liderava a exportação do café brasileiro e era representada pelas firmas Theodor Wille, Crossman \& Silken, Albucle. Esse plano, por outro lado, contava com a oposição do capital financeiro britânico e do governo federal e, para ser colocado em prática, precisava de garantias fornecidas pelo governo federal para realização da operação financeira e da aprovação da Caixa de Conversão no Congresso. Pelo plano colocado em prática, um cartel liderado por firmas norte-americanas e alemãs, que contava também com a participação da casa Prado Chaves \& Cia, cujo presidente era Antônio da Silva Prado, que anteriormente fora adversário do Plano. O cartel compraria grande parte do café escoado para Santos a um valor préestipulado e, armazenando-o nos EUA e na Europa, distribuiria o produto de forma racionada a fim de manter os preços em patamar elevado. O plano demorou para ser colocado em prática porque não contava com apoio do governo federal, cujo presidente era o paulista Rodrigues Alves. Enquanto os debates contra e a favor do plano eram realizados, a safra havia se iniciado, despertando temores e exaltando os ânimos no estado, os defensores do Convênio temiam que caso o plano demorasse a entrar em vigor e a safra começasse a ser vendida, os preços despencariam de maneira irreversível. Com a posse do novo presidente, o simples anúncio definitivo de que o plano entraria em vigor serviu para elevar as cotações do produto. $C f$. HOLLOWAY, op. cit., p. 66; TORELLI, 2004, op. cit.; KUGELMAS, 1987, op. cit. 
plano de Jacintho de Barros, que o senador Antônio Mercado apresentou ao Congresso Legislativo em outubro de 1903. Foi em um contexto de tensão quanto à aplicação do plano de valorização que o projeto n. 40 de Antônio Mercado, abandonado desde 1903, voltou a ser discutido no Congresso paulista. Dessa vez, deputados e senadores já não manifestavam divergência quanto à necessidade de o Estado vir a incentivar o financiamento agrícola, mas esta permanecia quanto ao tipo de instituição a ser fomentada e se haveria um ou dois bancos agrícolas.

Desde que as discussões sobre a criação de bancos agrícolas haviam se iniciado em 1896, surgira duas linhas de propostas sobre tal assunto. Uma delas apontava para a necessidade de dois bancos diferentes, um destinado a promover o custeio anual das fazendas, operando com o penhor agrícola e outro que deveria operar apenas com empréstimos hipotecários. Anos mais tarde, em 1899, o Congresso Legislativo estava novamente dividido entre a salvação do Banco de Crédito Real de São Paulo e a criação de um novo banco hipotecário que apenas emprestaria sobre hipotecas agrícolas. Nessa altura, começava a tramitar o projeto de um banco agrícola que seria subsidiado pelo Estado e obteria o direito de emitir letras tanto sobre hipotecas como sobre penhores. Desse modo foram aprovadas as leis n. 866, de 1903, e a de número 923, de 1904, propondo a criação de um banco agrícola hipotecário que operasse com penhor e hipoteca. Posteriormente, a proposta do banco agrícola evoluiria para a criação de um banco que deveria se especializar em operações hipotecárias e restrito à agricultura, enquanto a proposta dos Bancos de Custeio evoluiria para que eles cumprissem o financiamento de médio prazo sobre penhores. Assim, o resultado seria a formação de pequenos bancos locais, organizados como cooperativas e operando com penhor agrícola, que seriam os Bancos de Custeio Rural, e os empréstimos de médio e longo prazo ficariam sob a responsabilidade de um banco emissor de letras hipotecárias, o Banco de Crédito Hipotecário e Agrícola do Estado de São Paulo, fundado em 1909.

Enquanto esse debate ocorria no Congresso Legislativo, um grupo de grandes fazendeiros, comerciantes, banqueiros, muitos deles membros do legislativo, além do próprio Jacintho de Barros articularam a criação de uma companhia chamada Sociedade Incorporadora, que passou a propor-se no papel de organizadora dos Bancos de Custeio Rural. A sociedade Incorporadora era uma companhia por ações que se propunha a atuar como caixa central dos Bancos de Custeio Rural, tal como as centrais das caixas Raiffeisen. Seus estatutos, aprovados em 25 de agosto de 1906, diziam que o seu fim era 
organizar os Bancos de Custeio Rural, assim como sociedades congêneres de seguro, de consumo, etc.: e depois constituir-se centro da federação que se formar. Os estatutos da Sociedade Incorporadora foram aprovados em assembleia realizada na sede da Sociedade Paulista de Agricultura ${ }^{326}$. Percebe-se que a intenção manifesta pelos organizadores da Incorporadora era de que ela funcionasse como cooperativa central, não apenas das caixas de crédito, mas também de sociedades de consumo e de seguros mútuos.

Antonio Mercado, que fora o autor inicial do projeto n. 40 de 1903, já não ocupava mais cargo no legislativo e desse modo os parlamentares João Pedro da Veiga Filho, José Bonifácio de Oliveira Coutinho e Manuel Aureliano de Gusmão apresentaram um substitutivo ao projeto original e iniciaram as negociações para a aprovação da lei. Veiga Filho fora o relator da Comissão de Fazenda e Contas que, em 1903, apresentou parecer contrário ao pedido de Jacintho de Barros e, agora, mudara de opinião, assumindo a autoria do substitutivo ao projeto de Antônio Mercado. A única alteração significativa em relação ao projeto original foi a substituição do artigo primeiro que restringia o auxílio aos bancos organizados pela Sociedade Incorporadora. $\mathrm{O}$ trecho que dizia que $o$ 'Banco de Custeio Rural de Capivari' e os que se fundarem tomando aquele como tipo e de acordo com decreto federal n. 434, de 4 de julho de 1891, receberão auxílios do Estado ${ }^{327}$, foi substituído por receberão auxílio do Estado os 'Bancos de Custeio Rural' que forem organizados ou reorganizados pelos moldes da 'Sociedade Incorporadora'328.

Antes da aprovação do substitutivo ao projeto de Antônio Mercado, a Incorporadora surgira com o objetivo de organizar os Bancos de Custeio Rural. De acordo com o projeto original, esses bancos deveriam surgir de forma autônoma ainda que seguindo o modelo do banco experimental de Capivari. Mas segundo o substitutivo, a Incorporadora deveria centralizar a criação desses bancos, além de coordenar a gestão de seus ativos. Pelo artigo décimo terceiro de seus estatutos, a nova companhia assumia todas as formalidades legais de fazer a instalação, de contratar e pagar durante o primeiro ano o respectivo secretariado contador, recebendo por todo esse serviço sete oitavos das joias pagas pelos respectivos sócios fundadores ${ }^{329}$.

\footnotetext{
${ }^{326} 1^{\circ}$ REGISTRO DE IMÓVEIS DA CAPITAL. SOCIEDADE INCORPORADORA. Estatutos da Sociedade Incorporadora.

327 SÃO PAULO. ALESP: ACERVO HISTÓRICO. Projeto n. 40, de 1903, cx 60, p. 9.

${ }^{328}$ SÃO PAULO. ALESP: ACERVO HISTÓRICO. Projeto $n .40$ de 1903, cx 229.

${ }^{329} 1^{\circ}$ REGISTRO DE IMÓVEIS DA CAPITAL. SOCIEDADE INCORPORADORA. Estatutos da
} 
$\mathrm{Na}$ assembleia constituinte, cinquenta e quatro pessoas subscreveram 500 ações de um conto de réis cada. Em que pese Jacintho de Barros ter enfatizado que a gestão dos bancos de custeio deveria ser "democratizada", refletindo-se essa determinação na disposição que impedia aos sócios obterem mais de um voto nas assembleias, os estatutos da Sociedade Incorporadora não possuíam qualquer limitação nesse mesmo sentido, constituindo-se como uma sociedade anônima comum. Tratava-se de uma companhia por ações no controle de uma federação de cooperativas locais de crédito. Por outro lado, embora possamos perceber que os Bancos de Custeio Rural estivessem destinados a atender pequenos e médios fazendeiros de café, os acionistas da Sociedade Incorporadora podiam ser identificados como membros do grande capital cafeeiro, a maioria deles atuava nas mais diversas atividades, eram capitalistas, comissários de café, comerciantes, etc., além disso, todos os deputados e senadores envolvidos na aprovação do projeto $\mathrm{n}^{\circ}$ 40 compunham o quadro de acionistas da Incorporadora.

$\mathrm{Na}$ diretoria da entidade estavam Antônio Mercado, Augusto Ferreira Ramos, Cândido Rodrigues, Aureliano de Gusmão, Veiga Filho, Oliveira Coutinho, entre outros. A tabela a seguir mostra o quadro dos acionistas da Incorporadora. Em 1911, a direção da Sociedade Incorporadora foi profissionalizada, passando a ser controlada por um diretor gerente que não seria mais, necessariamente, um acionista ${ }^{330}$.

A assembleia de fundação companhia foi presidida por Antônio Candido Rodrigues, secretário da agricultura (monarquista em 1896 e defensor do Partido da Lavoura em 1899); foram convidados para secretariar a mesa os senhores João Pedro da Veiga Filho e Antônio Machado Cesar (comissário de café). Aprovados os estatutos da sociedade, foram escolhidos para a diretoria José Bonifácio de Oliveira Coutinho e Manoel Aureliano de Gusmão (coautores do substitutivo), além de Antônio Machado Cesar. Para o conselho fiscal da entidade, foram aclamados os nomes de Augusto Ferreira Ramos (Sociedade Paulista de Agricultura), o senador Antonio Dino da Costa Bueno e o Comendador Cícero Bastos e, para suplentes, José Candido da Silveira, Alfredo Alberto Fortes e José Jorge Marcondes Machado, e Jacintho de Barros foi escolhido quarto diretor, uma espécie de diretor de honra ${ }^{331}$. 
Após a reforma estatutária de 1911 Cândido, Jacintho de Barros e Antônio Dino da Costa Bueno passaram para o Conselho Fiscal. Nos primeiros documentos, datados de 1907, Augusto Ramos apareceu como diretor da Incorporadora, porém desaparecendo mais tarde.

Tabela 2: Quadro de acionistas da Sociedade Incorporadora em Agosto de 1906

\begin{tabular}{|c|c|c|c|}
\hline 1 & Antonio Dino da Costa Bueno (Dr.) & 28 & José Luiz de Almeida Nogueira (Dr.) \\
\hline 2 & Antonio Candido Rodrigues (Dr.) & 29 & José Jorge Marcondes Machado \\
\hline 3 & Antonio Mercado (Dr.) & 30 & José Candido da Silveira \\
\hline 4 & Antonio Saturnino Cardim (coronel) & 31 & Joao de Faria (Dr.) \\
\hline 5 & Antonio Machado Cesar & 32 & Joao Pedro da Veiga Filho (Dr.) \\
\hline 6 & Alfredo Rodrigues Jordão (Dr.) & 33 & João Ribeiro Marcondes Machado (Dr.) \\
\hline 7 & Alfredo de Toledo & 34 & João de Carvalho \\
\hline 8 & Alfredo Alberto Fortes & 35 & Jacintho Pereira da Silva Barros (Dr.) \\
\hline 9 & Augusto Ferreira Ramos (Dr.) & 36 & Julio Brandão Sobrinho (Dr.) \\
\hline 10 & Argemiro da Silveira (Dr.) & 37 & Luiz Gonzaga Mendes de Almeida (Dr.) \\
\hline 11 & Adolpho V. de Oliveira Coutinho (Dr.) & 38 & Luiz Gonzaga de Oliveira e Costa (Dr.) \\
\hline 12 & Arnaldo Vieira de Carvalho & 39 & Luiz Fagundes (Coronel) \\
\hline 13 & Aureliano de Souza e Oliveira Gusmão & 40 & Leopoldino M. Meira de Andrade (Dr.) \\
\hline 14 & Bernardino Avelino Gavião Peixoto (Cons.) & 41 & Manoel A. Duarte de Azevedo (Cons.) \\
\hline 15 & Clementino de Souza Castro & 42 & Manoel Aureliano de Gusmão (Dr.) \\
\hline 16 & Cicero Bastos (conselheiro) & 43 & Manoel P. de Siqueira Campos (Dr.) \\
\hline 17 & Domiciano de Campos & 44 & Manoel Augusto de Alvarenga (Dr.) \\
\hline 18 & Ernesto Pedroso & 45 & Manoel Netto de Araujo (Dr.) \\
\hline 19 & Fernando L. dos Santos Werneck (Dr.) & 46 & Mario Tavares (Dr.) \\
\hline 20 & Henrique Bastos & 47 & Olavo Egydio de Souza Aranha (Dr.) \\
\hline 21 & José Bonifácio de Oliveira Coutinho & 48 & Orozimbo R. de Amaral (Dr.) \\
\hline 22 & José Vieira Marcondes (Dr.) & 49 & Paulo Orozimbo de Azevedo (coronel) \\
\hline 23 & José Manoel da Fonseca Junior (Dr.) & 50 & Pedro Antonio Santangelo \\
\hline 24 & José Torres de Oliveira (Dr.) & 51 & Barão de Ribeiro Barbosa \\
\hline 25 & José Estanislau do Amaral (Dr.) & 52 & Rodrigo Lobato Marcondes Machado (Dr.) \\
\hline 26 & José Mariano C. de Camargo Aranha (Dr.) & 53 & Raul Renato Cardoso de Mello (Dr.) \\
\hline 27 & José Antonio Marcondes Machado (Dr.) & 54 & Sergio Meira (Dr.) \\
\hline
\end{tabular}

Tanto a Sociedade Incorporadora foi constituída para organizar e gerir a liquidez dos Bancos de Custeio como o próprio projeto da lei 1.062 foi alterado para que o auxílio fornecido pelo Estado recaísse apenas sobre as cooperativas organizadas por ela. Enquanto isso, a proposta dos Bancos de Custeio Rural havia evoluído e o seu futuro não dependeria mais do empenho de Jacintho de Barros, mas do quadro de acionistas da Incorporadora, cuja composição refletia a nova composição do poder político no estado de São Paulo. 
Assegurado o controle político sobre o processo de constituição dos Bancos de Custeio Rural, em 15 de dezembro de 1906, um parecer da Comissão de Indústria e Comércio foi favorável à execução do auxílio estatal. O relator da comissão era Antônio Cândido Rodrigues e, diferentemente do parecer da Comissão de Fazenda e Contas de 1903, o seu parecer foi amplamente favorável aos bancos de custeio:

Com intuitos tão alevantados e patrióticos, de alcance tão palpável para o amparo, progresso e normalidade da lavoura do Estado, mui naturalmente a 'Sociedade Incorporadora' despertou a atenção do legislador paulista e daí o substitutivo apresentado ao projeto Mercado pelos deputados Oliveira Coutinho, Aureliano de Gusmão e convertido no projeto de lei ora sujeito ao estudo da Comissão de Comercio e Industria do Senado.

O auxilio concedido pelo Estado da quantia de 50:000\$000 em 'apólices de auxilio agrícola' de juro de $8 \%$, será puramente de credito, simplesmente nominal, já porque operando com toda segurança sobre penhor agrícola, os bancos não podem dar prejuízos [...] nem mesmo o juro das apólices serão pagos pelo Governo, porquanto eles só são exigíveis depois da averbação das apólices no Tesouro do Estado, e esta averbação só se poderá dar no caso de liquidação forçada do banco que as houver recebido em penhor ou na execução do penhor que elas constituírem nesse banco ${ }^{332}$.

Após a aprovação da lei 1.062 em 29 de dezembro, todas as novas subscrições de ações foram realizadas por Bancos de Custeio na medida em que eles foram sendo organizados. Entretanto, durante todo o seu período de existência, os diretores e membros do conselho fiscal da Sociedade Incorporadora não estavam ligados aos Bancos de Custeio (possuidores da maioria das ações); seriam todos oriundos do grupo de acionistas da primeira subscrição, e apenas Jacintho da Silva Barros acumulava cargos nas diretorias do Banco de Custeio Rural de Jaboticabal e da Sociedade Incorporadora ${ }^{333}$.

\subsection{Organização da Sociedade Incorporadora e dos Bancos de Custeio}

Em 29 de dezembro de 1906 foi aprovada a lei estadual n. 1.062 que destinava um auxílio aos Bancos de Custeio Rural e estabelecia exigências estatutárias para que pudessem receber o apoio preconizado. Os primeiros dez bancos organizados pela Sociedade Incorporadora receberiam o empréstimo de 50 contos de réis em apólices da dívida pública, títulos especiais chamados Apólice de Auxílio Agrícola resgatáveis pelo portador em dez $\operatorname{anos}^{334}$. Esse auxílio deveria funcionar como impulso aos bancos de

${ }^{332}$ SÃO PAULO. ALESP: ACERVO HISTÓRICO. Projeto n. 40 de 1903, cx 229, pp. 4-8.

$3331^{\circ}$ REGISTRO DE IMÓVEIS DA CAPITAL. SOCIEDADE INCORPORADORA. Acta da Assemblea constituinte da Sociedade Incorporadora.

${ }^{334}$ SÃO PAULO. ALESP: ACERVO HISTÓRICO. Projeto n. 40 de 1903, cx 229, pp. 5 - "Substitutivo ao 
custeio e garantir suas primeiras operações. Regularmente, eles deveriam operar com recursos provenientes da atração de pequenos depósitos e empréstimos levantados na rede bancária e que, por sua vez, estariam garantidos pelos contratos de penhor firmados com os fazendeiros ${ }^{335}$.

A organização dos Bancos de Custeio continuaria a seguir estritamente o que fora planejado por Jacintho de Barros em 1903. Eles emprestariam apenas aos fazendeiros associados o valor estritamente necessário ao custeio anual da produção e sob a garantia do penhor da safra. Eles cumpririam uma função bastante específica que consistia na manutenção do fluxo de caixa das fazendas e o que, até então, coubera principalmente aos comissários de café. Assim como os bancos de custeio, a Sociedade Incorporadora não podia fazer concessão de crédito fora do âmbito de seus associados, esse impedimento deveria evitar operações especulativas que desvirtuassem da atenção dada aos fazendeiros ${ }^{336}$.

Em 1907, o senador e diretor da Incorporadora, Cândido Rodrigues reforçava ao presidente do estado os dois objetivos dos Bancos de Custeio:

Os bancos de custeio rural, Sr. Presidente, organizados sob o princípio da mutualidade, são verdadeiras sociedades cooperativas, que só operam nas comarcas em que se fundam e em benefício dos seus associados, aos quais, exclusivamente fornecem os recursos necessários para o custeio de suas lavouras, sob o penhor agrícola da produção, conquanto recebem destes e de terceiros, quantias em deposito a prazo fixo, e se encarregam de passagem de dinheiros para qualquer parte do pais ou do estrangeiro.

Além disso, si se considerar que estão reunidas no mutuário as duas qualidades de acionista e mutuário de banco, chega-se à conclusão de que todos terão empenho e interesse na pontualidade dos pagamentos, evitando assim prejuízos no instituto de crédito que tão bons serviços lhe presta ${ }^{337}$.

A lei $\mathrm{n}^{\mathrm{o}} 1.062$ determinava que cada BCR deveria ser organizado com um capital mínimo de 100 contos de réis, dividido em cem ações de um conto cada. Dessas cem ações, a Incorporadora deveria subscrever dez e a Câmara Municipal da localidade mais vinte. Desse modo garantia-se que para organizar um banco desse tipo os fundadores deveriam contar com o aval da Incorporadora e do poder político local. O restante das

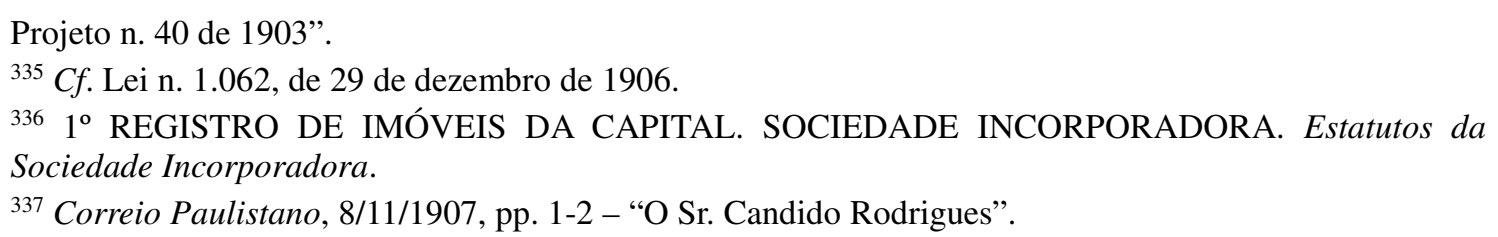


ações deveria ser subscrito apenas por fazendeiros que residissem no mesmo município do banco ou então em localidades vizinhas onde não houvesse banco do mesmo tipo.

É importante ressaltar que os bancos de custeio não eram sindicatos agrícolas, cujos estatutos possuíam determinações características de uma sociedade cooperativa, como eram as caixas Raiffeisen, tais como o princípio de "um homem, um voto" que impedia que determinado sócio obtivesse o controle da sociedade, mesmo que obtivesse um grande número de ações e o fato de que as ações não podiam ser negociadas livremente, mas apenas entre os sócios já admitidos ao grupo. A respeito dos dividendos, não se observa a ausência de lucro como no modelo Raiffeisen, porém o limitavam a $6 \%$ ao ano, e quando houvesse lucro superior, as sobras deveriam ser aplicadas no abatimento de juros dos empréstimos ou aplicado na realização do capital social. Desse modo, percebemos que as ações deveriam funcionar não como partícula de propriedade de uma determinada empresa, como é comum nas sociedades anônimas, mas como uma espécie de cota de participação em um bem coletivo. Outras características comuns às caixas Raiffeisen eram a administração restrita aos sócios e a operação dentro de um espaço geográfico delimitado.

No início de 1907, o governo do estado começou a firmar com a Sociedade Incorporadora os contratos para o fornecimento das apólices de auxílio agrícola aos primeiros Bancos de Custeio Rural. As cópias de dois desses contratos, de Taubaté e Sertãozinho, foram anexadas ao Relatório da Secretaria da Fazenda de 1907. Neles, Augusto Ferreira Ramos e Jacintho de Barros, dirigentes da Sociedade Incorporadora, se comprometiam a organizar aqueles bancos de custeio de acordo com a lei 1.062 e reforçavam o seu caráter associativo e as condições de utilização das apólices do auxílio agrícola ${ }^{338}$.

O Banco de Custeio Rural de Capivari já se encontrava liquidado, quando a lei 1062 foi aprovada e diversos bancos de custeio começaram a ser organizados pelo interior do estado. Em 14 de abril de 1907, o Banco de Custeio Rural de Ribeirão Bonito, organizado por Jacintho de Barros, em 1903, ainda permanecia em funcionamento e teve seus estatutos reformados para se adequar à lei 1.062 e se submeter ao controle da Sociedade Incorporadora ${ }^{339}$. A reorganização do banco usou como modelo os estatutos

338 SÃO PAULO. Relatorio Apresentado ao Dr. Jorge Tibiriçá, Presidente do Estado, Pelo Dr. Olavo Egydio de Souza Aranha, Secretario da Fazenda, 1907. São Paulo: Typ. do Diario Official, 1908.

${ }^{339}$ Diario Official do Estado de São Paulo, 12.5.1907, p. 1.445 - “Acta da assembleia extraordinaria do 
dos BCRs de Jaboticabal e Ribeirão Preto, que foram os primeiros a receber aprovação do governo paulista e contar com o seu auxílio.

Em 1907, o governo estadual aprovou os estatutos e firmou contratos para auxiliar bancos de custeio em Jaboticabal, Ribeirão Preto e Ribeirão Bonito, Serra Negra, Sertãozinho, Jaú e Taubaté, que receberam 50 contos de reis em apólices de auxílio agrícola $^{340}$. Além desses sete bancos estavam organizados os Bancos de Custeio Rural de Avaré, Bragança, Botucatu, Itapira, Pindamonhangaba e São José do Rio Pardo. Como havia ainda vários Bancos de Custeio sendo organizados, ultrapassando a cota de dez bancos a serem auxiliados pela lei 1.062, o senador Antônio Cândido Rodrigues apresentou em novembro de 1907 um projeto de lei propondo aumentar em 500 contos de réis a emissão de apólices de auxílio agrícola, com o objetivo de incentivar a marcha de seu desenvolvimento, com a possibilidade de auxiliar a criação de mais dez bancos de custeio $^{341}$.

Para sedimentar sua proposta, Cândido Rodrigues fez um relato das operações dos Bancos de Custeio já auxiliados, destacando o de Serra Negra, cuja diretoria foi bastante rápida. O auxilio foi aprovado em $1^{\circ}$ de setembro e no dia 19 ele já estava emprestando; em seguida, explica que como a lavoura daquele município encontrava-se bastante subdividida: de pequeno custeio depende suas propriedades, e por isso dos 12 contratos lavrados no total de 35:000\$000 apenas 1 é de 9:000\$000 sendo os outros de 3:000\$000 e menos ${ }^{342}$. Ainda, segundo o senador, os demais bancos auxiliados também vinham regularmente lavrando contratos, porém um tanto maiores sem entretanto serem grandes, pois temos adotado geralmente o critério de começar o fornecimento pelos pequenos lavradores, para ir subindo gradativamente ${ }^{343}$.

Em dezembro de 1907, foi aprovado o aumento de 500 contos de réis em apólices a serem entregues aos novos bancos, de acordo com o projeto de Candido Rodrigues. Desse modo, no início de 1908 foram aprovados os estatutos e firmados os contratos de auxílio aos bancos de Botucatu, Pindamonhangaba e São José do Rio Pardo. Em junho, quando uma comissão de fiscalização da Secretaria da Fazenda visitou esses bancos, eles

\footnotetext{
Banco de Custeio Rural de Ribeirão Bonito, em 14 de abril de 1907”.

${ }^{340}$ SÃO PAULO. Mensagem enviada ao Congresso Legislativo do Estado a 14 de julho de 1908 pelo Dr. M. J; Albuquerque Lins, Presidente do Estado.

${ }^{341}$ Correio Paulistano, 8/11/1907, pp. 1-2 - "O Sr. Candido Rodrigues".

342 Idem, ibdem.

343 Idem, ibdem.
} 
estavam operando normalmente ${ }^{344}$. No segundo semestre foram autorizados auxílios aos bancos de Descalvado, Jacareí, Lorena, Limeira, Santa Cruz do Rio Pardo Pirassununga e Itapira ${ }^{345}$ e, em 1909, foram aprovados ainda os estatutos de bancos em Taquaritinga, São Manoel e Santa Rita do Passa Quatro (organizados em 1909) ${ }^{346}$. Esses vinte primeiros bancos criados até 1909 foram beneficiados pelo auxílio em apólices e, por isso, estavam submetidos à fiscalização da Secretaria da Fazenda ${ }^{347}$.

Até 1913 surgiram quarenta e oito Bancos de Custeio associados à Incorporadora, desse total apenas vinte receberam auxílios do governo. Entre os BCRs que não receberam auxílios estava o BCR de Campinas que, embora tenha sido organizado em 1908, não obteve apólices. No Anuário Estatístico de 1909 aparecem os BCRs de Caçapava, Caconde, Casa Branca, Rio Claro e São Simão (vinte e seis bancos). No ano de 1910, surgiram bancos nas localidades de Agudos, Bauru, Itatinga, Piracaia e São Carlos (trinta e um). Em 1911, aparecem os bancos de Araraquara, Franca, Ibitinga, Mococa, Palmeiras e Piracicaba (trinta e seis). Em 1912, no Anuário Estatístico, aparecem os balanços dos BCRs em Bebedouro, Dois Córregos, Dourado, Igarapava, Itápolis, Monte Alto, Orlândia, São João da Boa Vista e Salto Grande do Paranapanema (quarenta e cinco $)^{348}$. Em 1914, de acordo com o relatório de falência da Sociedade Incorporadora, teriam surgidos os BCRs de Amparo, Espírito Santo do Pinhal e São José do Rio Preto (quarenta e oito).

\footnotetext{
${ }^{344}$ SÃO PAULO. Relatorio Apresentado [...] Secretario da Fazenda, 1907. São Paulo: Typ. do Diario Official, 1908.

${ }^{344}$ Diario Official do Estado de São Paulo, 12/5/1907, p. 1445 - "Acta da assembleia extraordinaria do Banco de Custeio Rural de Ribeirão Bonito, em 14 de abril de 1907".

${ }^{345}$ SÃO PAULO. Secretaria de Fazenda e do Thesouro do Estado de S. Paulo, Directoria de Fiscalização. Indice de Leis e Decretos da Secretaria da Fazenda de 1889 a 1933. São Paulo: Typ. Bancaria, 1934.

${ }^{346}$ SÃO PAULO. Congresso Legislativo do Estado de São Paulo. Coleção de leis e decretos do Estado de São Paulo. São Paulo: Imprensa Oficial do Estado, 1933.

347 SÃO PAULO. Relatorio Apresentado ao Dr. Manuel Joaquim de Albuquerque Lins, Presidente do Estado, Pelo Dr. Carlos Augusto Pereira Guimarães, Secretario Interino da Fazenda, 1910. São Paulo: Typ. Casa Garraux, 1911.

${ }^{348}$ SÃO PAULO. Annuario Estatístico de São Paulo, 1911. Estatísticas Econômicas e Financeiras. Vol. II, São Paulo: Typ. Brazil de Rothschild, 1913.
} 
Figura 2: Distribuição geográfica dos Bancos de Custeio Rural em 1913

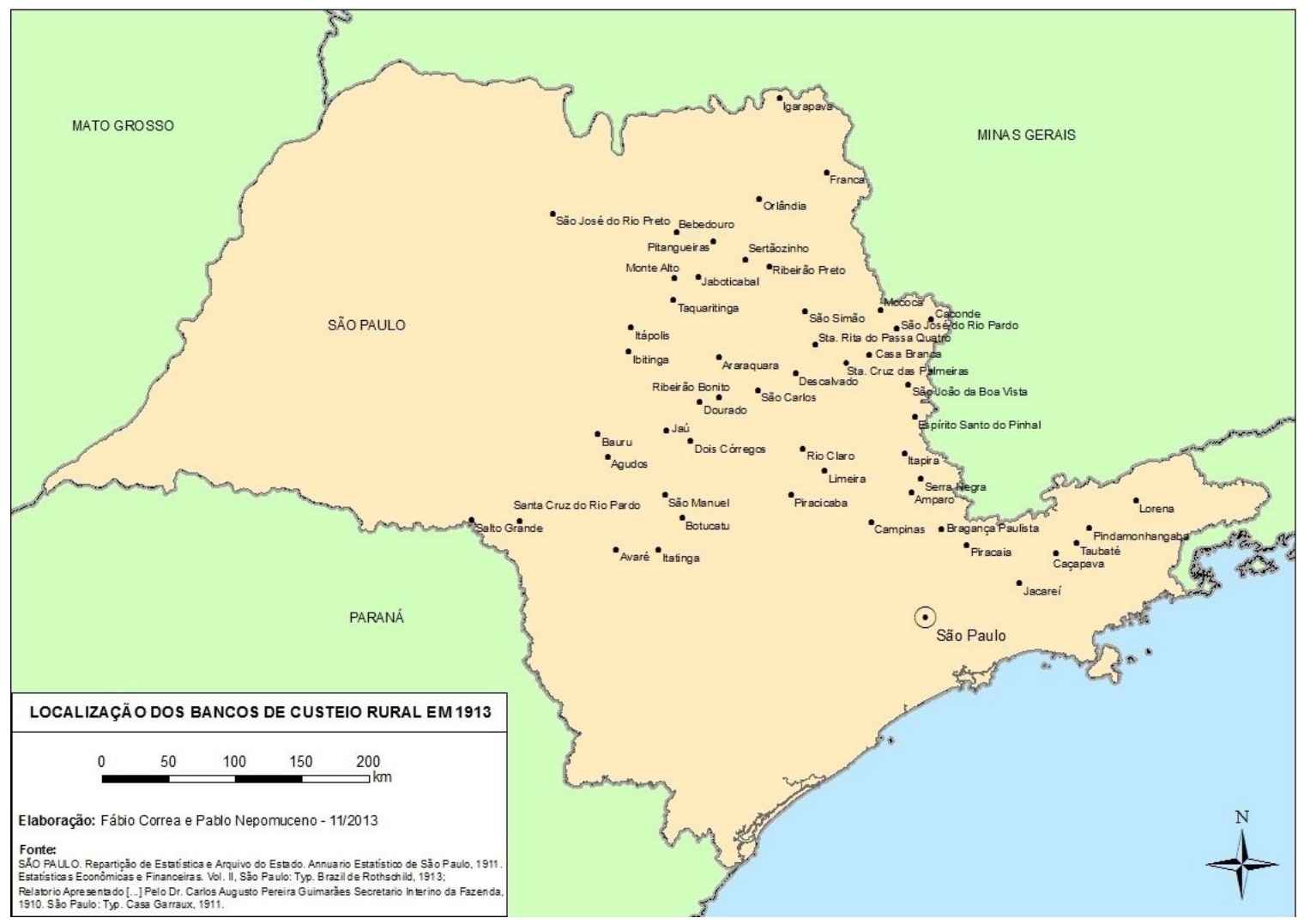

Ao longo da pesquisa, identificamos o funcionamento de Bancos de Custeio em outras cidades, no entanto, não conseguimos averiguar sua existência após 1907. Este é o caso do Banco de Custeio Rural de Avaré, organizado em 1903 pelo senador Antônio Cândido Rodrigues e que, segundo o mesmo senador, ainda estava em funcionamento em $1907^{349}$. Outro banco que chegou a ser organizado, mas que não obtivemos informações posteriores foi o de Bragança, constituído em novembro de 1906 e cuja assembleia constituinte fora presidida por Antônio de Machado Cesar, um diretor da Incorporadora ${ }^{350}$. Tanto o aludido BCR de Avaré como o de Bragança não chegaram a receber auxílio do governo estadual nem se associaram à Incorporadora e aparentemente não lograram êxito. Por outro lado, o Anuário Estatístico de 1912 indica a existência do Banco de Custeio Rural de Pitangueiras que não figurava na relação de bancos associados à Incorporadora, mas vinha emprestando regularmente. Desse modo, podemos dizer que o número confirmado de Bancos de Custeio existentes em 1913 era de 49, sendo 48 organizados pela Incorporadora, dos quais apenas vinte eram auxiliados pelo governo.

\footnotetext{
349 Correio Paulistano, 8/11/1907, pp. 1-2 - "O Sr. Candido Rodrigues".

${ }^{350}$ Correio Paulistano, 29/11/1906, p. 3 - "Bragança".
} 
Tabela 3: Composição acionária da Sociedade Incorporadora em 1914 (em contos de réis)

\begin{tabular}{|c|c|c|c|c|c|c|}
\hline & & $\begin{array}{l}\text { Primeiro } \\
\text { Aumento } \\
\text { de Capital - } \\
21 / 12 / 1907\end{array}$ & $\begin{array}{l}\text { Segundo } \\
\text { Aumento } \\
\text { de capital - } \\
17 / 12 / 1908\end{array}$ & $\begin{array}{l}\text { Terceiro } \\
\text { Aumento } \\
\text { de capital } \\
- \\
22 / 12 / 1910\end{array}$ & $\begin{array}{l}\text { Quarto } \\
\text { Aumento } \\
\text { de capital - } \\
30 / 12 / 1911\end{array}$ & $\begin{array}{l}\text { Quinto } \\
\text { Aumento de } \\
\text { capital (não } \\
\text { concluído) }\end{array}$ \\
\hline 1 & BCR de Jaboticabal & 50 & & & & \\
\hline 2 & BCR de Ribeirão Bonito & 50 & & & & \\
\hline 3 & BCR de Ribeirão Preto & 50 & & & & \\
\hline 4 & BCR de Sertãozinho & 50 & & & & \\
\hline 5 & BCR de Serra Negra & 50 & & & & \\
\hline 6 & BCR de Itapira & 50 & & & & \\
\hline 7 & BCR de Taubaté & 50 & & & & \\
\hline 8 & BCR de Jaú & 50 & & & & \\
\hline 9 & BCR de S. J. do Rio Pardo & 50 & & & & \\
\hline 10 & BCR de Pindamonhangaba & & 50 & & & \\
\hline 11 & BCR de Jacareí & & 50 & & & \\
\hline 12 & BCR de Descalvado & & 50 & & & \\
\hline 13 & BCR de Pirassununga & & 50 & & & \\
\hline 14 & BCR de Lorena & & 50 & & & \\
\hline 15 & BCR de Limeira & & 50 & & & \\
\hline 16 & BCR de S. C. do Rio Pardo & & 50 & & & \\
\hline 17 & BCR de Botucatu & & 50 & & & \\
\hline 18 & BCR de São Manoel & & 50 & & & \\
\hline 19 & BCR de Taquaritinga & & 50 & & & \\
\hline 20 & BCR de Caçapava & & & 50 & & \\
\hline 21 & BCR de S. R. Passa Quatro & & & 50 & & \\
\hline 22 & BCR de Caconde & & & 50 & & \\
\hline 23 & BCR de São Simão & & & 50 & & \\
\hline 24 & BCR de Rio Claro & & & 50 & & \\
\hline 25 & BCR de Piracaia & & & 50 & & \\
\hline 26 & BCR de Casa Branca & & & 50 & & \\
\hline 27 & BCR de Campinas & & & 50 & & \\
\hline 28 & BCR de Itatinga & & & 50 & & \\
\hline A. & Roteio Rural de Tremembé & & & 50 & & \\
\hline 29 & BCR de Palmeiras & & & & 50 & \\
\hline 30 & BCR de Ibitinga & & & & 50 & \\
\hline 31 & BCR de Araraquara & & & & 50 & \\
\hline 32 & BCR de Franca & & & & 50 & \\
\hline 33 & BCR de Piracicaba & & & & 50 & \\
\hline 34 & BCR de Bebedouro & & & & 50 & \\
\hline 35 & BCR de Monte Alto & & & & 50 & \\
\hline 36 & BCR de São Carlos & & & & 50 & \\
\hline 37 & BCR de Bauru & & & & 50 & \\
\hline 38 & BCR de Agudos & & & & 50 & \\
\hline 38 & BCR de Agudos & & & & 50 & \\
\hline 39 & BCR de S. G. Paranapanema & & & & & 50 \\
\hline 40 & BCR de Itápolis & & & & & 50 \\
\hline 41 & BCR de Orlândia & & & & & 50 \\
\hline 42 & BCR de Dourados & & & & & 50 \\
\hline 43 & BCR de E. Santo do Pinhal & & & & & 50 \\
\hline 44 & BCR de S. J. da Boa Vista & & & & & 50 \\
\hline 45 & BCR de Igarapava & & & & & 50 \\
\hline 46 & BCR de Dois Córregos & & & & & 50 \\
\hline 47 & BCR de Pitangueira & & & & & 50 \\
\hline 48 & BCR de Amparo & & & & & 50 \\
\hline & & 450 & 500 & 500 & 500 & 500 \\
\hline & & & \multicolumn{3}{|c|}{ Ações subscritas em agosto de 1906} & 50 \\
\hline & & & \multicolumn{3}{|c|}{ Capital nominal } & 2.500 \\
\hline
\end{tabular}

Fonte: SÃO PAULO. TJSP: ARQUIVO GERAL. "2o oficial da 1a Vara Commercial de São Paulo", Processo de Fallencia, Sociedade Incorporadora (v. 1), n. 12.504, cx 431 (Relatório dos síndicos da massa falida)

No quadro de acionistas apresentado acima aparece a participação da Associação de Roteio Rural de Tremembé como acionista da Sociedade Incorporadora, tratava-se de uma sociedade constituída para desenvolver o plantio irrigado de arroz na cidade de 
Tremembé e era presidida por Jacintho Ferreira da Silva Barros, com financiamento da Sociedade Incorporadora. A integração desse tipo de sociedade à Incorporadora era permitida por seus estatutos que incluíam a possibilidade de ela organizar sindicatos e sociedades de seguros mútuos.

Podemos observar pelo quadro anterior que os 50 acionistas iniciais da Incorporadora foram diluídos no quadro societário nos próximos aumentos de capital, o que ocorria na medida em que cada novo Banco de Custeio Rural subscrevia 50:000\$000 em ações. O capital social nominal da Incorporadora chegou a somar 2.500:000\$000 em 1913.

\subsection{Modo de operação e a atuação dos Bancos de Custeio Rural}

Os idealizadores dos Bancos de Custeio Rural pretendiam criar uma nova modalidade de financiamento que lhes permitisse emprestar aos associados os valores ao custeio anual de suas plantações, utilizando, por sua vez, os títulos representativos desse empréstimo como garantia para levantar recursos aos bancos estabelecidos na capital. Os dispositivos legais empregados eram amplamente utilizados pelo sistema de crédito do período, tais como a letra de câmbio, a conta corrente, o penhor agrícola e o mercantil. No entanto, esses mecanismos foram combinados em um sistema relativamente complexo que exporemos agora.

Do lado do indivíduo que contraía o empréstimo, os bancos de custeio apareciam como um instrumento de crédito mútuo, onde a união de capitais, a fiscalização recíproca e o empenho da safra futura conferiam uma garantia sólida para que obtivesse acesso privilegiado ao crédito bancário, enquanto a Incorporadora atuava negociando com o sistema bancário condições vantajosas de refinanciamento aos bancos de custeio. $\mathrm{Na}$ outra ponta, estavam os bancos comerciais estabelecidos na capital, que tinham nessas dezenas de pequenos bancos espalhados pelo interior paulista, oportunidade de expandir suas operações em direção ao interior, onde a solvabilidade dos fazendeiros era de difícil aferição. $\mathrm{O}$ anseio pela instalação de pequenos bancos no interior, os chamados bancos regionais, é evidente em relatórios oficiais e na imprensa do período. É também recorrente a menção feita à capilaridade do sistema bancário britânico, que tinha grande capacidade de captar depósitos e fazer empréstimos. Nesse sentido, instalados próximos aos clientes, os bancos de custeio se encontrariam na condição de cumprir tal papel, avaliando o crédito e servindo de intermediário com os bancos da capital. De modo que os riscos com 
avaliação e concessão dos empréstimos fossem diminuídos tanto pela proximidade com os tomadores como pela organização mutual, em relação à qual se atribuía solidez devido à responsabilidade dos tomadores de empréstimos enquanto sócios.

Os bancos nacionais e estrangeiros com sede na capital paulista dispunham de pouquíssimas agências no interior, mas contavam com correspondentes em diversos pontos que se encarregavam de realizar cobranças das letras de câmbio adquiridas por desconto pela instituição sediada na capital. Apenas algumas cidades contavam com agências bancárias e os poucos bancos que surgiram com sede no interior apresentaram uma vida bastante turbulenta e efêmera até a década de $1920^{351}$.

Como já discutimos anteriormente, de modo geral, o sistema bancário não tinha mecanismo para financiar a agricultura e o crédito bancário era concedido principalmente com desconto de letras de câmbio, operação geralmente utilizada no curto prazo e mais adequada ao comércio. Os Bancos de Custeio, entretanto, encontraram um modo de fazer da letra de câmbio um veículo para o crédito de médio prazo (doze meses). Assim, para compreender o seu funcionamento torna-se necessário compreender minimamente o funcionamento da letra de câmbio. O crédito concedido pelos Bancos de Custeio Rural consistia em um contrato de penhor estabelecido com o fazendeiro acionista e inscrito no registro de hipotecas da localidade. O contrato garantia ao fazendeiro o financiamento por três anos consecutivos, que cobria o custeio de três safras consecutivas, cujo valor era estipulado com base em uma estimativa do custo da produção anual da fazenda.

Enquanto o banco se comprometia a conceder o empréstimo, o fazendeiro se comprometia a aceitar no início de cada um dos três anos de sua vigência uma letra de câmbio em favor do banco, com vencimento para doze meses. O banco, por sua vez, realizava o seu desconto, mas não pagava imediatamente ao fazendeiro, dividindo o pagamento da letra em doze parcelas que eram creditadas mensalmente na conta corrente do fazendeiro. Em suma, o empréstimo consistia no desconto de uma letra de câmbio para doze meses que tinha como garantia o penhor agrícola. O banco fornecia os recursos ao fazendeiro durante os doze meses de vigência da letra e no momento de sua liquidação, quando então o mutuário já vendera o café, ele dispunha dos recursos necessários para saldar a dívida, assim a liquidação do empréstimo se fazia pelo pagamento da letra mais a taxa de $6 \%$ de desconto, que vinha a ser o juro anual da operação. Em seguida, dando

${ }^{351}$ SAES, op. cit., p. 110; pp. 123-6. 
continuidade ao contrato, o fazendeiro emitia uma nova letra para o próximo período e a operação se repetia por mais duas vezes até o fim do contrato. Vencido o contrato, eles decidiam se o renovavam por mais três anos ${ }^{352}$.

Figura 3: Anúncio do Banco de Custeio Rural de Ribeirão Preto

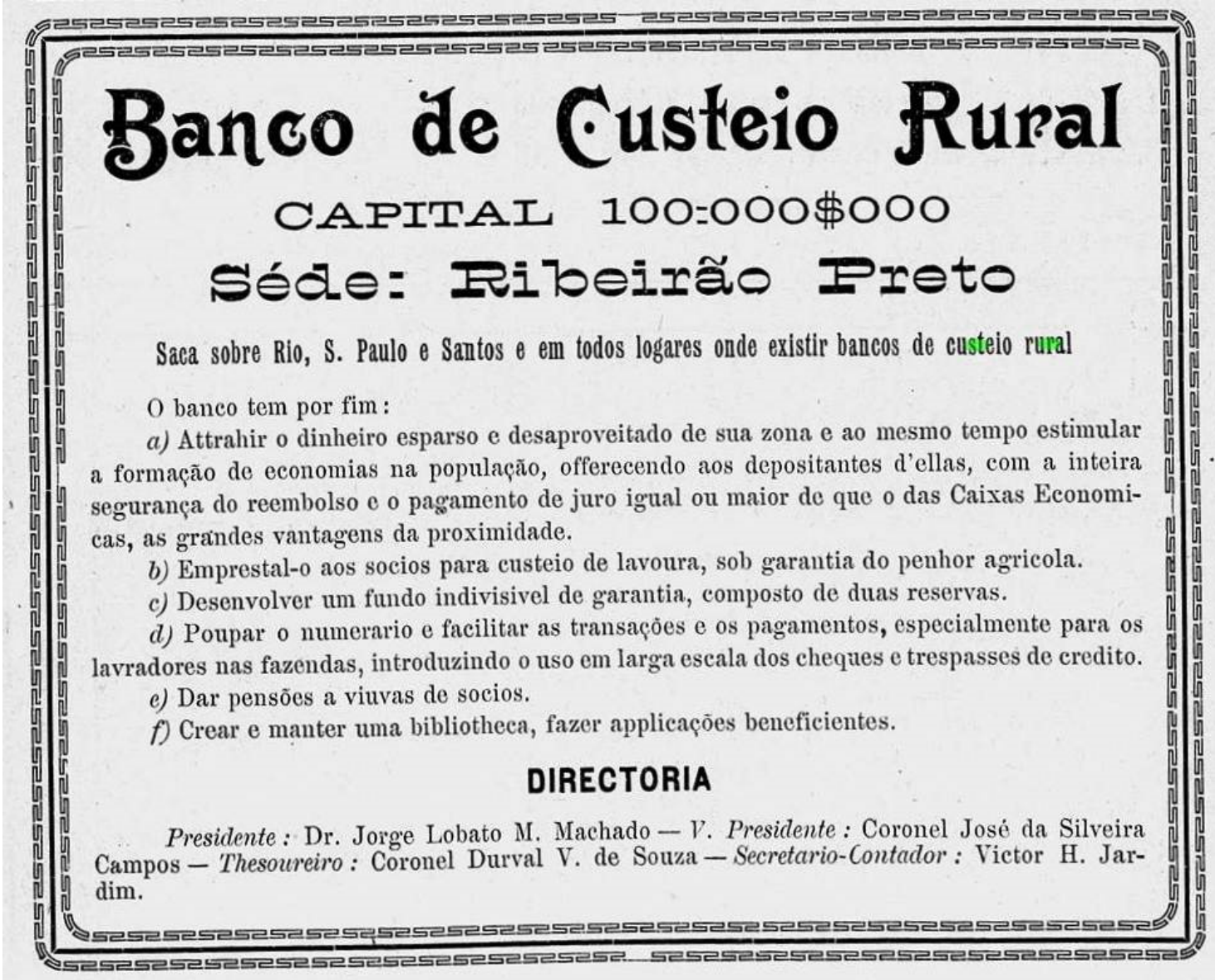

Tomemos como exemplo o contrato estabelecido entre o Banco de Custeio Rural de Campinas e o fazendeiro Joaquim Antonio Leite de Oliveira, inscrito no registro de hipotecas daquela comarca em 15 de janeiro de 1912. Esse contrato tinha vigência de três anos e estabelecia um financiamento de 10 contos de réis por ano e taxa de desconto de $6 \%$. Nessa operação, o fazendeiro emitiu em favor do banco uma letra no valor 10 contos de réis que o banco descontava e punha-lhe à disposição 833,333 mil-réis em uma conta corrente todos os meses até o vencimento da letra. Essa operação estava garantida pelo penhor de seis mil arrobas de café, duas mil de cada uma das safras de 1912, 1913 e 1914. As letras tinham vencimento para o dia 31 de dezembro de cada um dos três anos ${ }^{353}$.

\footnotetext{
${ }^{352}$ Diario Official do Estado de São Paulo. 1/2/1907 "Estatutos do Banco de Custeio Rural de Jaboticabal". 353 TRIBUNAL DE JUSTIÇA DO ESTADO DE SÃO PAULO. ARQUIVO GERAL. " $2^{\circ}$ oficial da $1^{\text {a }}$ Vara Commercial de São Paulo", Processo de Fallencia, Sociedade Incorporadora (v. 1), n. 12.504, cx 431, pp.
} 
O pagamento das parcelas nem sempre era realizado em dinheiro, nos primeiros anos, os BCRs entregavam aos mutuários notas promissórias de valor equivalente a 1/5 dos empréstimos contratados e com vencimento para doze meses e eram utilizadas como meio de pagamento. Porém, em 1910, eles abandonaram a entrega de notas e passaram a disponibilizar o valor integral dos empréstimos em parcelas mensais na conta corrente do mutuário; valores que podiam ser sacados mediante emissão de cheques ${ }^{354}$.

O credor da lavoura poderia conceder os empréstimos utilizando-se apenas da garantia conferida pelo penhor da safra, mas optou-se pelo uso da letra de câmbio em auxílio ao contrato de penhor. O contrato de penhor atrelado ao aceite da letra de câmbio se explica pela dupla garantia que era oferecida ao credor, garantia pessoal oferecida pela letra e a garantia real conferida pelo contrato pignoratício. Por outro lado, o compromisso de pagamento da letra de câmbio permitia aos Bancos de Custeio Rural descontar esses títulos na rede bancária, modo pelo qual levantavam os recursos necessários para emprestar aos fazendeiros.

\subsection{Os empréstimos concedidos pelos BCRs}

De acordo com os contratos firmados entre o governo de São Paulo e a Sociedade Incorporadora, os Bancos de Custeio que recebiam as Apólices de Auxílio Agrícola passavam a submeter-se à físcalização da Secretaria da Fazenda. Uma comissão de fiscalização passou a visitar anualmente esses bancos para analisar seus balanços e os contratos firmados.

Os relatórios dessa comissão foram publicados anexos ao Relatório da Secretaria da Fazenda e constituem importante fonte para o conhecimento de suas operações. Eles descreviam detalhadamente as operações realizadas pelos bancos de custeio, operações que dificilmente poderiam ser descritas apenas pela análise dos balanços, pois uma mesma operação de financiamento aparecia pelo menos duas vezes no ativo desses bancos, uma vez como conta corrente e outra como desconto das letras de câmbio. ${ }^{355}$. Entretanto nesses relatórios só encontramos os dados referentes aos bancos submetidos à fiscalização do governo, ou seja, dez bancos em 1907 e vinte a partir de 1909. Por outro lado, os balanços de todos os Bancos de Custeio, inclusive aqueles não estavam

111-114 (contrato de penhor anexado ao processo).

${ }^{354}$ SÃO PAULO. Relatorio [...] Secretario Interino da Fazenda, 1910. São Paulo: Typ. Casa Garraux, 1911. ${ }^{355}$ SÃO PAULO, Relatorio Apresentado ao Dr. Jorge Tibiriçá, Presidente do Estado, Pelo Dr. Olavo Egydio de Souza Aranha, Secretario da Fazenda, 1907, São Paulo: Typ. do Diario Official, 1908. 
submetidos à fiscalização, foram publicados no Anuário Estatístico do Estado de São Paulo, mas apenas as séries de 1908, 1909 e 1912 nos permitiram quantificar os empréstimos, dada a ausência de padronização.

$\mathrm{Na}$ tabela abaixo, demonstramos as operações de crédito efetuadas no exercício de 1907 pelos dez bancos fiscalizados.

Tabela 4: Empréstimos realizados pelos Bancos de Custeio Rural em 1907

\begin{tabular}{|c|c|c|c|c|}
\hline & Contratos & $\begin{array}{l}\text { Valor dos } \\
\text { empréstimos }\end{array}$ & $\begin{array}{l}\text { Média dos } \\
\text { contratos }\end{array}$ & $\begin{array}{l}\text { Penhor de } \\
\text { café } \\
\text { (arrobas) }\end{array}$ \\
\hline Serra Negra & 22 & $53: 875 \$ 000$ & $2: 448 \$ 864$ & 15.387 \\
\hline São J. do Rio Pardo & 19 & 74:040\$000 & $3: 896 \$ 842$ & 30.100 \\
\hline Ribeirão Preto & 13 & $72: 250 \$ 000$ & $5: 596 \$ 154$ & 29.300 \\
\hline Sertãozinho & 13 & $138: 000 \$ 000$ & $10: 615 \$ 385$ & 56.400 \\
\hline Jaboticabal & 16 & $104: 410 \$ 000$ & $6: 525 \$ 625$ & 42.097 \\
\hline Ribeirão Bonito & 7 & $68: 400 \$ 000$ & $9: 771 \$ 428$ & 22.500 \\
\hline Jaú & 8 & $105: 390 \$ 000$ & $13: 173 \$ 750$ & 35.133 \\
\hline Botucatu & 20 & $96: 150 \$ 000$ & $4: 807 \$ 500$ & 32.116 \\
\hline Pindamonhangaba & 20 & $88: 400 \$ 000$ & $4: 420 \$ 000$ & 25.281 \\
\hline Taubaté & 27 & 159:000\$000 & $5: 888 \$ 889$ & 46.778 \\
\hline Totais & 165 & $960: 415 \$ 000$ & $5: 820 \$ 696$ & 335.092 \\
\hline
\end{tabular}

Vemos acima que o total dos empréstimos concedidos em 1907 pelos Bancos de Custeio foi de 960:415\$000, créditos garantidos por 335.092 arrobas de café ao preço médio de 3\$000 a arroba. Analisando o relatório de 1907, percebemos que os empréstimos individuais variaram entre $600 \$ 000$ e 30:000\$000 e representaram uma média de 5:820\$696; não é arriscado dizer que significavam pequenas quantias, principalmente quando as contrastamos com o valor do financiamento de grandes fazendas, o que, para efeito de comparação, tomamos os valores de custeio da fazenda Guatapará, de propriedade da família Prado e que produzia 165.000 arrobas de café em 1900. Naquela safra, as despesas de produção montaram a 481:000\$000 356 , sendo oitenta e duas vezes maiores que a média dos empréstimos concedidos pelos Bancos de Custeio, sete anos depois. Podemos fazer outra comparação com o custeio da Fazenda Monte Alegre, em Ribeirão Preto, financiada pela casa exportadora Theodor Wille e que, em 1905, produzia 20.000 arrobas de café que custaram 100:974\$870. Essas comparações

\footnotetext{
${ }^{356}$ IEB, Fundo Caio Prado Junior, "Fazenda Guatapará”, Caixa 17, doc. CPJ-FG1296.
} 
demonstram que a clientela dos bancos de custeio era composta por pequenos e médios fazendeiros.

Para dar conta desses empréstimos, os Bancos de Custeio enviavam as letras de câmbio emitidas pelos fazendeiros à Sociedade Incorporadora que, por sua vez, ocupavase de contratar a seu favor empréstimos ao British Bank.

Tabela 5: Recursos levantados do British Bank no exercício 1907/8

\begin{tabular}{|c|c|c|c|}
\hline Banco de Custeio & $\begin{array}{l}\text { Letras endossadas } \\
\text { e caucionadas ao } \\
\text { British Bank }\end{array}$ & $\begin{array}{c}\text { Apólices de auxílio } \\
\text { agrícola } \\
\text { caucionadas }\end{array}$ & $\begin{array}{l}\text { Empréstimos } \\
\text { obtidos com o } \\
\text { British Bank }\end{array}$ \\
\hline Serra Negra & $53: 875 \$ 000$ & $50: 000 \$ 000$ & $43.100 \$ 000$ \\
\hline São José do Rio Pardo & $65: 040 \$ 000$ & $50: 000 \$ 000$ & $48.912 \$ 000$ \\
\hline Ribeirão Preto & $72: 000 \$ 000$ & $50: 000 \$ 000$ & $57.600 \$ 000$ \\
\hline Sertãozinho & $66: 000 \$ 000$ & $50: 000 \$ 000$ & $52.800 \$ 000$ \\
\hline Jaboticabal & $62: 485 \$ 000$ & $50: 000 \$ 000$ & $50.000 \$ 000$ \\
\hline Ribeirão Bonito & $68: 400 \$ 000$ & $50: 000 \$ 000$ & $50.000 \$ 000$ \\
\hline Jaú & $62: 400 \$ 000$ & $50: 000 \$ 000$ & $49.920 \$ 000$ \\
\hline Botucatu & $64: 800 \$ 000$ & $50: 000 \$ 000$ & $50.000 \$ 000$ \\
\hline Pindamonhangaba & $85: 400 \$ 000$ & $50: 000 \$ 000$ & $50.000 \$ 000$ \\
\hline Taubaté & $86: 100 \$ 000$ & $50: 000 \$ 000$ & $50.400 \$ 000$ \\
\hline Totais & $686: 500 \$ 000$ & $500: 000 \$ 000$ & $502.732 \$ 000$ \\
\hline
\end{tabular}

Fonte: SÃO PAULO. Relatorio [...], Secretario da Fazenda, 1907. São Paulo: Typ. do Diario Official, 1908

De acordo com o relatório apresentado à Secretaria da Fazenda, os fiscais demonstraram que os recursos foram obtidos por meio de contas correntes garantidas pelo penhor de apólices e letras de câmbio e por meio destas cauções obtiveram os bancos capitais na importância de 502:732\$000, 80\% aproximadamente do valor das letras ${ }^{357}$. Não sabemos, entretanto, a que taxa esses recursos foram levantados. A Incorporadora havia fornecido como garantia 686.500\$000 em “letras pignoratícias" mais 500:000\$000 em Apólices do Auxílio Agrícola. É preciso ressaltar que o empréstimo obtido pelos

357 SÃO PAULO, Relatorio Apresentado ao Dr. Jorge Tibiriçá, Presidente do Estado, Pelo Dr. Olavo Egydio de Souza Aranha, Secretario da Fazenda, 1907. São Paulo: Typ. do Diario Official, 1908, p. 370. 
bancos era cerca de $30 \%$ inferior ao valor das letras, pois, somando-se as letras e as apólices, o total de títulos caucionados foi de 1.186:500\$000.

Conforme discutido anteriormente, no ato da assinatura do contrato, os BCRs forneciam aos fazendeiros notas promissórias no valor de 1/5 do total do financiamento contratado com vencimento para doze meses. O restante do valor contratado era dividido em doze parcelas a serem creditadas mensalmente na conta do mutuário, como vemos na tabela seguinte:

Tabela 6: Forma de financiamento pelos BCRs (réis)

\begin{tabular}{lccc}
\hline Banco de Custeio & $\begin{array}{c}\text { Valor pago em } \\
\text { promissórias }\end{array}$ & $\begin{array}{c}\text { Valor pago em } \\
\text { dinheiro }\end{array}$ & $\begin{array}{c}\text { Valor das parcelas } \\
\text { mensais }\end{array}$ \\
\hline Serra Negra & $10: 775 \$ 000$ & $43: 100 \$ 000$ & $3: 591 \$ 670$ \\
São José do Rio Pardo & $14: 808 \$ 000$ & $59: 232 \$ 000$ & $4: 936 \$ 000$ \\
Ribeirão Preto & $14: 550 \$ 000$ & $58: 200 \$ 000$ & $4: 850 \$ 000$ \\
Sertãozinho & $27: 600 \$ 000$ & $110: 400 \$ 000$ & $9: 200 \$ 000$ \\
Jaboticabal & $20: 882 \$ 000$ & $83: 528 \$ 000$ & $6: 960 \$ 670$ \\
Ribeirão Bonito & $13: 680 \$ 000$ & $54: 720 \$ 000$ & $4: 560 \$ 000$ \\
Jaú & $21: 078 \$ 000$ & $84: 312 \$ 000$ & $7: 026 \$ 000$ \\
Botucatu & $19: 230 \$ 000$ & $76: 920 \$ 000$ & $6: 410 \$ 000$ \\
\hline Pindamonhangaba & $17: 680 \$ 000$ & $70: 720 \$ 000$ & $5: 893 \$ 330$ \\
\hline Taubaté & $31: 800 \$ 000$ & $127: 200 \$ 000$ & $10: 600 \$ 000$ \\
\hline
\end{tabular}

Observemos por essa tabela que os BCRs puderam aliviar o seu caixa em 92:083\$000, fornecendo parte dos empréstimos em notas promissórias, sendo o restante creditado à razão de 64:027\$667 todos os meses na conta dos mutuários. O valor total dos compromissos parcelados era de 768:332\$000. Desse modo, vemos que apenas os 502:732\$000 contraídos inicialmente não poderiam dar conta dessas operações, entretanto, de acordo com balanço geral das operações dos dez bancos que foi apresentado pela comissão de fiscalização aparece no passivo geral um valor de 280:469\$146, denominado "conta corrente", possivelmente fruto de depósitos; porém analisando os relatórios seguintes, percebemos que essa conta era utilizada para registrar haveres da 
Sociedade Incorporadora com os BCRs ${ }^{358}$. Esses depósitos em conta corrente somados ao valor captado por meio de empréstimos com o British Bank montavam a 783:201\$146, saldo suficiente para cobrir todas as prestações.

Figura 4: Anúncio do Banco de Custeio Rural de Jaboticabal

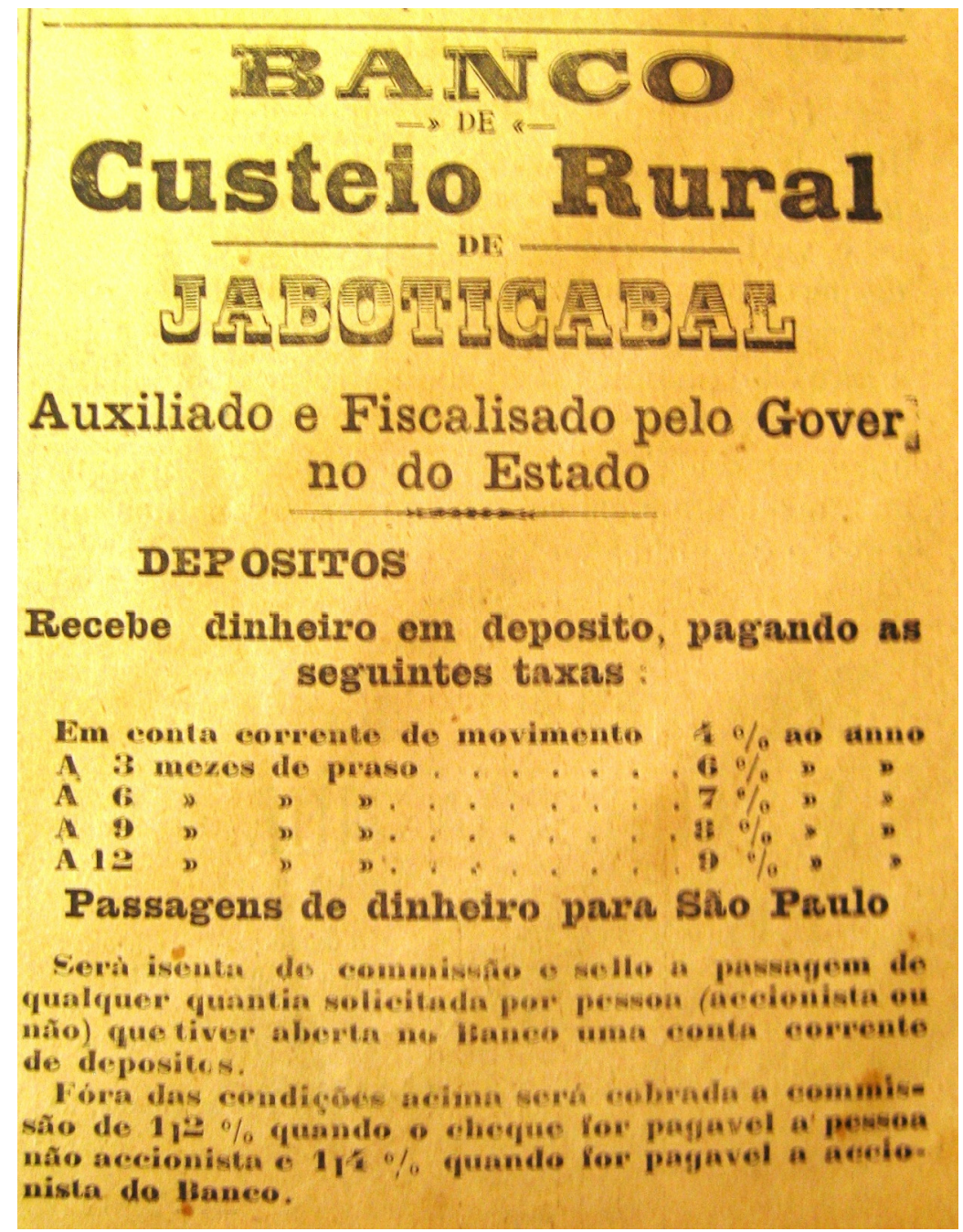

Por ocasião do relatório de 1910, a situação dos Bancos de Custeio Rural era bem diferente. Em dezembro de 1907, o governo estadual emitira mais 500:000\$000 em Apólices do Auxílio Agrícola, permitindo o auxílio a mais dez bancos; entretanto, outros dez bancos haviam sido organizados pela Incorporadora ainda que não tenham recebido o auxílio das apólices, ou seja, havia vinte bancos auxiliados e suas apólices garantiam indiretamente a operação de outros dez bancos filiados à incorporadora. No ano de 1910, o conjunto dos vinte bancos fiscalizados firmou contratos de penhor no valor de

358 SÃO PAULO. Relatorio Apresentado ao Dr. Jorge Tibiriçá, Presidente do Estado, Pelo Dr. Olavo Egydio de Souza Aranha, Secretario da Fazenda, 1907. São Paulo: Typ. do Diario Official, 1908, p. 371-2, Balancetes. 
4.045:142\$000 e levantou recursos da ordem de 3.686:523\$000, considerando-se ainda a existência de 1.000:000\$000 apólices de auxílio agrícola em caução.

Aparentemente, esses recursos entraram nos registros dos bancos unicamente para fins contábeis, pois existe uma intensa movimentação da conta existente com a Incorporadora, na qual esses recursos figuram como débito daquela sociedade.

Tabela 7: Operações de crédito realizadas pelos BCRs em 1910 (mil réis)

\begin{tabular}{|c|c|c|c|c|c|}
\hline Banco de Custeio & $\begin{array}{l}\text { Valor dos } \\
\text { contratos }\end{array}$ & $\begin{array}{l}\text { Valor das } \\
\text { parcelas }\end{array}$ & $\begin{array}{l}\text { Antecipação } \\
\text { de parcelas }\end{array}$ & $\begin{array}{l}\text { Empréstimos } \\
\text { contratados }\end{array}$ & $\begin{array}{l}\text { Saldo com a } \\
\text { Incorporadora }\end{array}$ \\
\hline Botucatu & 130.200 & 10.850 & 10.206 & 108.450 & -68.719 \\
\hline Descalvado & 332.500 & 27.708 & 18.261 & 333.500 & 112.329 \\
\hline Itapira & 247.389 & 20.616 & 1.872 & 210.394 & 202.198 \\
\hline Jaboticabal & 265.500 & 22.125 & 5.362 & 172.000 & 191.715 \\
\hline Jacareí & 130.849 & 10.904 & 28.008 & 136.545 & 73.629 \\
\hline Jaú & 361.700 & 30.142 & 65.832 & 307.200 & 2.035 \\
\hline Limeira & 130.300 & 10.858 & 2.060 & 130.300 & 109.125 \\
\hline Lorena & 147.684 & 12.307 & 13.987 & 147.684 & -2.759 \\
\hline Pindamonhangaba & 155.500 & 12.958 & 7.560 & 179.600 & -64.098 \\
\hline Pirassununga & 77.400 & 6.450 & 3.784 & 54.600 & 12.850 \\
\hline Ribeirão Bonito & 168.800 & 14.067 & 5.999 & 136.700 & 69.951 \\
\hline $\begin{array}{l}\text { Ribeirão Preto } \\
\text { Santa Cruz }\end{array}$ & $\begin{array}{r}530.300 \\
39.500\end{array}$ & $\begin{array}{r}44.192 \\
3.292\end{array}$ & $\begin{array}{r}79.810 \\
4.189\end{array}$ & $\begin{array}{r}440.300 \\
39.500\end{array}$ & $\begin{array}{r}-142.643 \\
-183\end{array}$ \\
\hline Santa Rita & 146.000 & 12.167 & 9.114 & 143.000 & 30.058 \\
\hline S. J. do Rio Pardo & 351.600 & 29.300 & 16.602 & 309.600 & 281.854 \\
\hline São Manoel & 66.500 & 5.542 & 1.818 & 66.500 & 53.198 \\
\hline Serra Negra & 96.220 & 8.018 & 4.189 & 96.220 & 25.000 \\
\hline Sertãozinho & 302.000 & 25.167 & 13.022 & 317.000 & 68.986 \\
\hline Taquaritinga & 238.800 & 19.900 & 15.734 & 185.800 & -86.664 \\
\hline \multirow[t]{2}{*}{ Taubaté } & 126.400 & 10.533 & 22.619 & 171.630 & 57.799 \\
\hline & 4.045 .142 & 337.095 & 330.027 & 3.686 .523 & 925.662 \\
\hline
\end{tabular}

Percebe-se logo de início o aumento expressivo do volume emprestado aos associados entre 1907 e 1910. Em 1907, os dez bancos haviam emprestado 960:415\$000, enquanto os vinte bancos fiscalizados em 1910 haviam fornecido 4.045:142\$000, isso sem considerar os bancos não fiscalizados.

O movimento intenso da conta "sociedade incorporadora" sugere que os recursos arrecadados não iam diretamente para o caixa dos BCRs e ficavam sob a guarda da Incorporadora, que os disponibilizara em conta corrente. Apenas os BCRs de Botucatu, Lorena, Pindamonhangaba, Ribeirão Preto e Taquaritinga aparecem com saldo devedor 
nessa conta, os demais aparecem como credores $^{359}$. O relatório de 1910 também demonstra que as operações haviam se diversificado com o fornecimento de cheques, inclusive para não associados (utilizados para realizar pagamentos em outras praças) e aumento considerável dos depósitos, principalmente a prazo, além da operação com warrants. Considerando todos os créditos concedidos por contratos de penhor, antecipação de parcelas e warrants, os Bancos de Custeio fiscalizados emprestaram 4.393:169\$000 e mantinham um saldo credor para com a Incorporadora em 925:662\$000.

Tabela 8: Empréstimos concedidos pelos 20 Bancos de Custeio auxiliados e fiscalizados pelo governo (mil réis)

\begin{tabular}{|c|c|c|c|c|c|c|c|}
\hline & & 1907 & 1908 & 1909 & 1910 & 1911 & 1912 \\
\hline 1 & Botucatu & 96.150 & 154.949 & 97.200 & 113.700 & & 225.750 \\
\hline 2 & Descalvado & & 158.000 & 190.500 & 333.500 & & 525.500 \\
\hline 3 & Itapira & & 36.194 & 67.995 & 210.304 & 100.400 & 417.000 \\
\hline 4 & Jaboticabal & 104.590 & 113.540 & 205.525 & 172.000 & 250.900 & 249.800 \\
\hline 5 & Jacareí & & 153.585 & 143.586 & 112.449 & & 149.300 \\
\hline 6 & Jaú & 105.390 & 145.990 & 175.190 & 268.200 & & 357.090 \\
\hline 7 & Limeira & & 102.000 & 114.000 & 130.500 & 334.500 & 391.100 \\
\hline 8 & Lorena & & 106.090 & 122.790 & 147.684 & 172.968 & 276.176 \\
\hline 9 & Pindamonhangaba & 99.716 & 170.800 & 158.600 & 179.600 & 512.000 & 201.600 \\
\hline 10 & Pirassununga & & 90.500 & 54.500 & 54.600 & 140.500 & 124.200 \\
\hline 11 & Ribeirão Bonito & 72.180 & 144.300 & 149.300 & 127.700 & & 251.100 \\
\hline 12 & Ribeirão Preto & 73.250 & 154.500 & 217.200 & 435.300 & 672.300 & 797.500 \\
\hline 13 & S. C. do Rio Pardo & & 162.500 & 151.500 & 39.500 & 250.500 & 376.000 \\
\hline 14 & Sta. R. do P. Quatro & & & 69.000 & 143.000 & 195.900 & 278.400 \\
\hline 15 & S. José do Rio Pardo & 74.040 & 221.240 & 192.600 & 300.600 & 176.400 & 455.000 \\
\hline 16 & São Manoel & & & 20.400 & 66.500 & & \\
\hline 17 & Serra Negra & 53.875 & 71.375 & 53.550 & 84.220 & 160.020 & 184.100 \\
\hline 18 & Sertãozinho & 188.250 & 141.000 & 158.000 & 287.000 & & 428.000 \\
\hline 19 & Taquaritinga & & & 58.400 & 185.800 & 222.800 & 334.800 \\
\hline \multirow[t]{2}{*}{20} & Taubaté & 159.000 & 156.230 & 102.030 & 147.630 & 152.300 & 303800 \\
\hline & Total & 1.026 .441 & 2.282.793 & 2.501 .866 & 3.539 .187 & 3.341 .488 & 6.326.216 \\
\hline
\end{tabular}

Lembrando-se que um dos objetivos dos Bancos de Custeio Rural era funcionar como caixa rural, captando pequenos depósitos, principalmente aqueles provenientes das economias dos colonos, os bancos de custeio tinham uma conta de pequenos depósitos remunerados, admitidos a partir de $1 \$ 000$. Para atrair a confiança dos colonos, eles afixaram em suas sedes, com autorização do governo, plaquetas: Banco de Custeio Rural auxiliado e fiscalizado pelo governo do Estado. Em 1914, quando da recusa do governo em salvar a Sociedade Incorporadora e os Bancos de Custeio, um colunista do jornal $O$ Comércio de São Paulo chegou a argumentar que, se o governo não se sentia responsável por salvar aqueles bancos, ele era responsável por salvar as economias dos colonos,

${ }^{359}$ A esse respeito os fiscais informaram que em 1910 muitos dos bancos só conseguiram manter a receita acima das despesas por conta dos juros que a Sociedade Incorporadora pagou por esse crédito. 
incultos, que confiaram na indicação do governo para aplicar suas poupanças. Alertavase que, caso o socorro não ocorresse, a paz social no interior correria sério risco ${ }^{360}$, nos dias seguintes o jornal divulgou notícias de motins e pancadarias promovidas por depositantes, mas isso não foi noticiado por outro veículos.

Tabela 9: Total de depósitos nos BCRs em 1910 (mil reis)

\begin{tabular}{|c|c|c|c|c|}
\hline Banco de Custeio & $\begin{array}{l}\text { Pequenos } \\
\text { depósitos }\end{array}$ & $\begin{array}{c}\text { Depósitos a } \\
\text { prazo fixo }\end{array}$ & $\begin{array}{l}\text { Depósito em } \\
\text { conta corrente }\end{array}$ & $\begin{array}{c}\text { Total de } \\
\text { depósitos }\end{array}$ \\
\hline Botucatu & 34.781 & 47.355 & 75.208 & 157.344 \\
\hline Descalvado & 4.822 & 50.790 & 234.193 & 289.503 \\
\hline Itapira & 30.577 & - & - & 30.577 \\
\hline Jaboticabal & 31.327 & 27.041 & - & 58.368 \\
\hline Jacareí & 6.885 & - & - & 6.885 \\
\hline Jaú & 19.225 & 27.610 & 122.504 & 169.339 \\
\hline Limeira & 22.116 & 75.226 & 115.710 & 213.052 \\
\hline Lorena & 12.810 & 39.213 & 43.811 & 95.834 \\
\hline Pindamonhangaba & 5.750 & 4.360 & 25.193 & 5.749 \\
\hline Pirassununga & 10.630 & - & - & 10.630 \\
\hline Ribeirão Bonito & 14.915 & 64.372 & - & 79.287 \\
\hline Ribeirão Preto & 7.907 & 2.018 & 3.995 & 13.920 \\
\hline Santa Cruz & 2.903 & 9.156 & 20.468 & 32.527 \\
\hline Santa Rita & 3.421 & 39.981 & - & 43.402 \\
\hline S. J. do Rio Pardo & 20.868 & 151.592 & 254.797 & 427.257 \\
\hline São Manoel & 14.833 & - & - & 14.833 \\
\hline Serra Negra & 15.692 & 6.697 & - & 22.388 \\
\hline Sertãozinho & 30.431 & 39.151 & - & 69.582 \\
\hline Taquaritinga & 1.273 & 3.210 & 29.200 & \\
\hline \multirow[t]{2}{*}{ Taubaté } & 2.376 & - & - & 2.376 \\
\hline & 293.542 & 587.772 & 925.079 & 1.742 .854 \\
\hline
\end{tabular}

Conforme se observa pela tabela acima, havia outras duas contas para depósitos, uma para depósitos a prazo, também chamada "letra por dinheiro a prêmio", categoria na qual o banco recebia o dinheiro e entregava ao depositante uma nota promissória em seu favor, contendo o prazo para resgate e a remuneração estipulada, além dos depósitos simples em conta corrente, utilizados principalmente para movimentar valores entre os municípios e fazer pagamentos e cobranças em favor de terceiros

A Incorporadora também realizava uma série de operações que lhe traziam rendimentos, a maioria delas em acordo com seus estatutos, é o caso da cobrança de títulos 
de terceiros. A operação de cobrança, em particular, é muito interessante por ilustrar as práticas creditícias daquele período, marcado pela centralização das atividades bancárias na capital paulista e tendo a letra de câmbio como principal mecanismo de crédito. Nesse contexto, os bancos comerciais da capital paulista realizavam grande quantidade de operações de descontos de letras de câmbio, cujo pagamento, muitas vezes, deveria ser realizado em cidades do interior do estado. Desse modo, os bancos da capital tinham letras para receber em diversas cidades do interior paulista, onde não dispunham de agências e por isso encarregavam a cobrança a terceiros, pagando por esse serviço uma comissão. A Incorporadora como entidade central de uma federação de bancos, presentes em 48 cidades, encontrava-se em condição privilegiada para cobrar esses títulos em nome dos bancos da capital. Essa não era uma operação de crédito e estava prevista em seus estatutos, tendo se constituído em uma importante fonte de receita, haja vista o elevado número de bancos e empresas importadoras que reivindicaram a devolução dessas letras quando se iniciou o processo de falência ${ }^{361}$.

Outra importante atividade da Sociedade Incorporadora era a transferência de dinheiro entre os municípios. Nessa operação qualquer comerciante podia depositar uma quantia em um dos Bancos de Custeio e sacar um cheque contra essa mesma conta e remetê-lo para desconto na capital ou em alguma cidade onde houvesse Banco de Custeio. O relatório da comissão de inspeção dos Bancos de Custeio Rural definia da seguinte forma essas operações: sem fugir aos seus estatutos também tem os bancos de custeio rural prestado ao comercio importantes serviços, encarregando-se da passagem de fundos das diversas localidades em que têm sede para esta Capital e da cobrança de títulos por conta de terceiros ${ }^{362}$. Quando ocorreu a falência da Incorporadora, diversas operações desse tipo foram interrompidas e depositantes reivindicaram à administração da massa falida a devolução do dinheiro, como, por exemplo, a reclamação de Josino de Alvarenga Freire, que poucos dias antes da falência entregou à Incorporadora $a$ importância de seiscentos e sessenta mil réis (Rs. 660\$000) em moeda corrente, para que

${ }^{361}$ SÃO PAULO. TJSP: Arquivo Geral. "20 Oficial da $1^{\text {a }}$ Vara Commercial de São Paulo", Reclamação Reivindicatória, caixas 431-7.

362 SÃO PAULO. Relatorio Apresentado ao Dr. Manuel Joaquim de Albuquerque Lins, Presidente do Estado, Pelo Dr. Carlos Augusto Pereira Guimarães, Secretario Interino da Fazenda, 1910. São Paulo: Typ. Casa Garraux, 1911, p. 369. 
[...] passasse a referida importância para a cidade de Limeira, ao Sr. Manuel de Alvarenga Freire ${ }^{363}$.

Abaixo um modelo de cheque da Sociedade Incorporadora utilizado nas transferências de valores:

Figura 5: Cheque sacado contra a Sociedade Incorporadora pelo BCR de Caçapava



Em outro caso, uma correspondência entre a casa comissária Prado, Chaves \& Cia e o administrador da Fazenda Guatapará, de propriedade da família Prado, datada de primeiro de setembro de 1910, observa-se a utilização dos cheques do Bancos de Custeio Rural de Ribeirão Bonito por aquela fazenda localizada em Ribeirão Preto: Comunicamos lhe ter ontem lançado a credito de sua conta corrente a importância de Rs. $875 \$ 000$, que recebemos em pagamento ao cheque 24.416, a nosso favor, saque do Banco de Custeio Rural de Ribeirão Bonito, a cargo da Sociedade Incorporadora ${ }^{364}$.

Visando agora determinar a importância dos Bancos de Custeio Rural na economia paulista, comparamos os dados dos balanços que esses bancos publicaram no Anuário Estatístico e os dados compulsados por Flávio Saes sobre o volume de crédito que o sistema bancário emprestava no ano de 1912. Verificamos que os 46 bancos de custeio rural existentes naquele ano haviam emprestado pouco mais de 11 mil $\operatorname{contos}^{365}$,

${ }^{363}$ SÃO PAULO. TJSP: Arquivo Geral. "20 Oficial da $1^{\text {a }}$ Vara Commercial de São Paulo", Reclamação Reivindicatória, n. 12.670, caixas 431-7 "Josino Alvarenga Freire".

${ }^{364}$ IEB. FUNDO CAIO PRADO JUNIOR, Fazenda Guatapará. Ref. CPJ-FG-1025.

${ }^{365}$ SÃO PAULO. Repartição de Estatistica e Arquivo do Estado. Annuario Estatistico do Estado de São Paulo, 1912. Estatísticas Economica e Financeira. Vol. II, São Paulo: Typ. Do Diario Official, 1914. 
enquanto os bancos de capital nacional emprestaram 141 mil contos, sendo assim, os Bancos de Custeio representavam, pelo menos nesse ano, quase $8 \%$ dos empréstimos com capital nacional ${ }^{366}$. Entretanto, os bancos de custeio tinham pouco mais de mil contos de réis em depósitos contra 110 mil do restante dos bancos nacionais. Dessa comparação, percebe-se que os bancos de custeio chagaram a ter uma participação expressiva na distribuição do crédito bancário, muito embora não conseguissem captar uma quantia equivalente em depósitos.

\subsection{Os Bancos de Custeio e a Sociedade Incorporadora dentro do sistema bancário paulista}

Até aqui analisamos um primeiro circuito no qual atuavam os Bancos de Custeio Rural em sua relação com os fazendeiros associados. Agora entramos no segundo circuito de operações dessa rede de crédito, que se estabelecia entre os Bancos de Custeio e a Sociedade Incorporadora e entre esta última com a rede bancária. Nesse circuito as letras de câmbio aceitas pelos fazendeiros, os chamados títulos de penhor, eram descontadas pelos Bancos de Custeio e repassadas à Sociedade Incorporadora que as utilizava para tomar empréstimos à rede bancária em favor dos bancos associados. Se os relatórios da Comissão de Inspeção nos proporcionam uma ótima visão do funcionamento dos bancos de custeio, a análise do processo de falência nos revelou o funcionamento da Incorporadora e o seu movimento em conjunto com os bancos de custeio. Ao que tudo indica os bancos de custeio mantiveram suas atividades restritas ao âmbito que lhes fora atribuído pelos estatutos, emprestando apenas aos fazendeiros sob penhor agrícola. Mas a Incorporadora atuava de maneira mais diversa, contrariando, inclusive, seus estatutos ao realizar operações que lhe eram proibidas, como o desconto de letras de terceiros.

Em primeiro lugar, voltemos aos depósitos realizados pela Sociedade Incorporadora nos bancos de custeio e que aparecem sob a denominação de "contas correntes" no relatório fiscal de 1907 e "Sociedade Incorporadora" no relatório de 1910. Por essa conta percebia-se que a Incorporadora havia fornecido aos bancos de custeio por meio de conta corrente o valor de 280:469\$146, em 1907. Não consta em nenhum dos documentos analisados que a Incorporadora houvesse recebido do Tesouro qualquer quantia para auxiliar os bancos de custeio. Uma explicação possível para a origem desses recursos é que os valores dos empréstimos contratados com o British Bank eram maiores

${ }^{366}$ SAES, 1986, op. cit., p. 222. 
que o montante de 502:732\$000 recebido pelos bancos de custeio, de modo que a Incorporadora permanecia com uma parte dos recursos e os redistribuía aos bancos de acordo com suas necessidades e, possivelmente, também aplicava em operações diversas que permitissem a valorização do saldo ocioso.

Por outro lado, a forma como o conjunto, Incorporadora e BCRs, tomavam recursos à rede bancária e os transferiam aos mutuários para fins de custeio encerrava um grave problema. Enquanto o contrato de penhor era a única atividade de crédito realizada pelos bancos de custeio e os pagamentos aos fazendeiros deveriam ser divididos em parcelas mensais, os bancos obtinham os recursos de uma só vez, valor que nesse caso montava a 502:732\$000, muito embora tivessem compromissos de apenas 64:027\$667 a cada mês. Desse modo havia sempre sobra de recursos e a tabela a seguir demonstra a situação do caixa dos Bancos de Custeio em junho de 1908:

Tabela 10: Provisão de recursos em junho de 1908 (réis)

\begin{tabular}{|c|c|c|c|c|c|}
\hline Banco de Custeio & $\begin{array}{l}\text { Empréstimos } \\
\text { obtidos com a } \\
\text { caução }\end{array}$ & $\begin{array}{c}\text { Valor das } \\
\text { mensalidades } \\
\text { dos mutuários }\end{array}$ & $\begin{array}{l}\text { Pequenos } \\
\text { depósitos }\end{array}$ & Caixa & $\begin{array}{c}\text { Capacidade } \\
\text { de } \\
\text { pagamento }\end{array}$ \\
\hline Serra Negra & $43.100,000$ & $3.591,667$ & 304,500 & $25.149,760$ & 12 \\
\hline S. J. do Rio Pardo & $48.912,000$ & $4.936,000$ & $2.349,000$ & $47.590,167$ & 9,9 \\
\hline Ribeirão Preto & $57.600,000$ & $4.850,000$ & 365,000 & $8.892,265$ & 11,9 \\
\hline Sertãozinho & $52.800,000$ & $9.200,000$ & $2.249,700$ & $14.588,650$ & 5,8 \\
\hline Jaboticabal & $50.000,000$ & $6.960,667$ & 180,000 & $23.436,170$ & 7,2 \\
\hline Ribeirão Bonito & $50.000,000$ & $4.560,000$ & $1.736,500$ & $13.477,344$ & 10,9 \\
\hline Jahu & $49.920,000$ & $7.026,000$ & 146,360 & $16.815,000$ & 7,1 \\
\hline Botucatu & $50.000,000$ & $6.410,000$ & 479,000 & $16.845,000$ & 7,8 \\
\hline Pindamonhangaba & $50.000,000$ & $5.893,333$ & 192,000 & $8.005,447$ & 8,5 \\
\hline \multirow[t]{2}{*}{ Taubaté } & $50.400,000$ & $10.600,000$ & $1.118,000$ & $28.000,300$ & 4,8 \\
\hline & $502.732,000$ & $64.027,667$ & $9.120,060$ & 202800,103 & 7,9 \\
\hline
\end{tabular}

Vemos que mesmo tendo recebido pouco mais de $70 \%$ do compromisso assumido nos contratos de penhor, os bancos de custeio tinham a sua disposição quantias muito elevadas diante dos seus compromissos mensais. Em média, os recursos recebidos permitiam pagar 7,9 parcelas, e, em junho de 1908, o caixa dos bancos permanecia com 202:800\$103, quantia que era suficiente para cobrir saques da conta de "pequenos depósitos" no valor de 9:120\$060 e ainda satisfazer o pagamento de três parcelas a mutuários $^{367}$. Por outro lado, percebemos que os recursos não eram distribuídos

\footnotetext{
${ }^{367}$ Normalmente os bancos comerciais têm em caixa apenas um percentual do valor depositado (o chamado encaixe) para cobrir os saques, enquanto o restante permanece aplicado, mas neste caso ocorre o contrário.
} 
igualmente entre os bancos na medida de seus contratos de penhor, pois enquanto a soma dos contratos variou entre 53:875\$000 (BCR de Serra Negra) e 159:000\$000 (BCR de Taubaté), todos os bancos receberam mais ou menos a mesma quantia, por volta de 50:000\$000. Assim, enquanto o BCR de Serra Negra recebeu recursos suficientes para pagar 12 parcelas, o BCR de Taubaté recebeu recursos para apenas 4,8 parcelas. Isso se explicava pelo fato de a Incorporadora redistribuir a liquidez dos bancos federados, fazendo as diferenças se anularem em conta correntes que mantinham em cada banco.

No entanto, no conjunto das operações, a Sociedade Incorporadora tinha um saldo a seu favor de 280:469\$146 em relação aos bancos de custeio em 1907. Esses valores que apareciam em conta corrente não eram provenientes dos 502:732\$000, pois estes apareceriam como haveres dos bancos de custeio e não o contrário, como pudemos observar. O que concluímos é que a Incorporadora levantara com a rede bancária recursos por sua própria conta, possivelmente utilizando-se da posse das letras e apólices dos bancos de custeio, para levantar empréstimos para o seu próprio caixa.

Isso pôde ser observado com maior segurança no relatório de 1910, quando os recursos levantados no mercado de crédito não apareciam mais individualizados como se fossem contraídos individualmente por cada banco, mas contraídos em conjunto pela Incorporadora e depois colocados à disposição dos bancos associados em conta corrente. A tabela seguinte mostra um quadro geral das relações entre Bancos de Custeio e Sociedade Incorporadora dias antes desta última ter declarado falência.

A Incorporadora, munida dos títulos pertencentes aos bancos de custeio contratava com os bancos comerciais sediados na Capital empréstimos em conta corrente que eram redistribuídos aos bancos associados. Inicialmente essa operação era realizada apenas com o British Bank e posteriormente foram estendidas ao London and Brazilian Bank, Banque Bresilienne Italo-Belge, Caixa Filial do Banco do Brasil e com o Banco de Crédito Hypothecário e Agricola do Estado de São Paulo ${ }^{368}$ e esses créditos eram levantados ao custo de $8 \%$ e $12 \%$ e repassados aos bancos de custeio ao juro de $9 \%$ ao ano.

Tabela 11: Movimentação da Sociedade Incorporadora em dezembro de 1913

${ }^{368}$ SÃO PAULO. TJSP: ARQUIVO GERAL. " $2^{\circ}$ Oficial da $1^{a}$ Vara Commercial de São Paulo", Processo de Fallencia, Sociedade Incorporadora (v. 2), n. 12.659 cx 431 (2a Vara Cível, 6 de janeiro de 1914), pp. 420-437. 
Títulos em poder da Incorporadora

\begin{tabular}{lr}
\hline $\begin{array}{l}\text { Letras pignoratícias repassadas pelos BCRs (estoque e fluxo) } \\
\text { Caucionadas }\end{array}$ & $10.671: 200 \$ 000$ \\
Descontadas & $3.757: 700 \$ 000$ \\
$\quad$ Em carteira & $2.077: 700 \$ 000$ \\
Apólices do Estado & $4.835: 800 \$ 000$ \\
\hline $\begin{array}{l}\text { Recursos levantados e repassados aos BCRs } \\
\text { Empréstimos levantados junto a rede bancária }\end{array}$ & \\
Quantia repassada aos BCRs & $5.034: 100 \$ 000$ \\
\hline $\begin{array}{l}\text { Saldo credor e devedor dos BCRs } \\
\text { BCRs devedores à Incorporadora }\end{array}$ & $4.391: 072 \$ 069$ \\
\hline BCRS credores da Incorporadora & $2.115: 990 \$ 499$ \\
\hline Relaçãoda Incorporadora com terceiros & $1.945: 951 \$ 030$ \\
\hline Títulos descontados de terceiros (em carteira e caucionados) & $727: 894 \$ 564$ \\
\hline Contas correntes abertas a terceiros
\end{tabular}

Quando ocorreu a falência da Sociedade Incorporadora, em 1914, diversos jornais paulistas apontaram que o motivo da falência era a insolvência de vários comissários de café de Santos com a Incorporadora. Entretanto, o empréstimo dos fundos pertencentes aos bancos de custeio a terceiros era proibido, o que gerou grande polêmica e diversas matérias, principalmente no $O$ Estado de São Paulo, que acusaram a Incorporadora de se deixar atrair pela especulação e até mesmo de haver fraudado o fundo comum dos bancos de custeio; outro jornal, O Comércio de São Paulo publicou várias colunas em defesa da diretoria e fazia apelos para que o governo socorresse os Bancos de Custeio. Esse jornal publicou uma entrevista com os advogados da Incorporadora em que se explicava que a dívida dos comissários para com a entidade era legal, fruto de letras aceitas por comissários em favor dos fazendeiros que, por sua vez, eram utilizadas por estes para efetuar os pagamentos aos bancos de custeio ${ }^{369}$, versão esta que não foi confirmada pelo relatório dos síndicos da falência, como veremos adiante. Por outro lado, o jornal $O$ Estado de São Paulo deu notável repercussão ao relatório dos síndicos da massa falida, revelado em março de 1914 e que acusava a diretoria da Incorporadora de haver descontando letras de comissários, inclusive a descoberto, além de várias fraudes como lucro fictício e beneficiamento de devedores específicos ${ }^{370}$.

${ }^{369}$ O Commercio de São Paulo, 1.1.1914 a 5.3.1914.

${ }^{370}$ O Estado de São Paulo, 5.3.1914. 
Os jornais publicaram partes do relatório que acusava a entidade de ter se desviado de seus próprios princípios ao não respeitar o artigo $14^{\circ}$ de seus estatutos, o qual determinava que não era permitido fazer empréstimos e abrir crédito senão aos bancos e sociedades da federação, além disso, eles demonstraram uma série de irregularidades cometidas pela diretoria $^{371}$. De fato, a sociedade tinha grande quantidade de letras de comissários em seu poder, inclusive as redescontou na Caixa Filial do Banco do Brasil, o que pudemos perceber era uma atividade realizada sistematicamente ainda que vedada por seus estatutos.

Lembremos mais uma vez que a principal atribuição da Incorporadora era concentrar as garantias dos bancos e com elas arrecadar recursos que deveriam ser remetidos aos bancos associados. No entanto, entre a aquisição desses valores na capital paulista e a sua remessa aos bancos de custeio, havia um intervalo no qual ela aplicava os recursos devidos em descontos de títulos de terceiros, principalmente de casas comissárias de Santos, redescontando-os, por sua vez, na rede bancária. Essas operações eram realizadas em grande monta, tanto que a sua falência se deveu à quebra da casa comissária Uchoa \& Cintra, em 1913. A Incorporadora havia descontado grande valor em títulos dessa casa que, endossados (afiançados) pela Incorporadora foram redescontados na Caixa Filial do Banco do Brasil, que acabou protestando o não pagamento. Como o endosso a tornara corresponsável pelas letras daquela firma, com a falência, a Incorporadora foi protestada e acabou tendo falência declarada em 2 de janeiro de 1914.

Nos bancos citados anteriormente, a Incorporadora havia realizado o mesmo tipo de operação. Ela solicitava um empréstimo em conta corrente e ao mesmo tempo redescontava títulos de terceiros por ela endossados. Essas operações eram, por sua vez, garantidas pelos títulos de penhor de fazendeiros e apólices pertencentes aos Bancos de Custeio. Por exemplo, em um contrato com o The British Bank of South America, ela descontou letras no total de 300:200\$000 e contratou um empréstimo em conta corrente no valor de 277:939\$820 à taxa de 11\% ao ano, e como garantia dessa operação ela entregou ao banco 623:100\$000 em títulos de penhor e 300:000\$000 em apólices do auxílio agrícola ${ }^{372}$.

${ }^{371} 1^{\circ}$ REGISTRO DE IMÓVEIS DA CAPITAL. SOCIEDADE INCORPORADORA. Estatutos da Sociedade Incorporadora.

${ }^{372}$ SÃO PAULO. " $2^{\circ}$ Oficial da $1^{\text {a }}$ Vara Commercial de São Paulo", Processo de Fallencia, Sociedade Incorporadora (v. 2), n. 12.659 cx 431 (2a Vara Cível, 6 de Janeiro de 1914), p. 423. 
Em 1914, a Sociedade Incorporadora era devedora de bancos da capital paulista na quantia de 5.549:989\$242. Sendo 2.215:405\$400 ao Banco de Crédito Hipotecário e Agrícola; 1.143:066\$924 à Caixa Filial do Banco do Brasil; e 1.610:452\$200 ao British Bank. Ela havia descontado letras no valor de 3.614:885\$880 e contraído 2.230:195\$312 na forma de empréstimo em conta corrente. Das letras descontadas, 1.439:130\$660 eram letras de câmbio de terceiros, o que equivale a quase $40 \%$ do total de descontos, sendo a maior parte redescontada na Caixa Filial do Banco do Brasil, no valor total de 792:482\$900373. Os síndicos da massa falida produziram uma lista descriminando esses títulos, em que foi possível observar que a taxa de desconto variara entre $10 \%$ e $12 \%{ }^{374}$. Além disso, a Incorporadora também realizou empréstimos em conta corrente a firmas comerciais e que, segundo os síndicos, foram concedidos a descoberto e atingiram o valor de $727: 894 \$ 564$.

O quadro seguinte demonstra as relações de crédito da Sociedade Incorporadora com terceiros, quando de sua falência em janeiro de 1914.

Tabela 12: Relação da Incorporadora com terceiros em Janeiro de 1914

\begin{tabular}{|c|c|}
\hline Títulos descontados de terceiros (em carteira e caucionados) & 1.945:951\$030 \\
\hline Contas correntes abertas a terceiros & $727: 894 \$ 564$ \\
\hline Total do crédito concedido a terceiros & $2.673: 845 \$ 594$ \\
\hline
\end{tabular}

Tendo analisado como os Bancos de Custeio realizavam os empréstimos aos fazendeiros e como eles levantavam esses recursos na rede bancária, faltava descobrir como tal sistema era mantido, se os empréstimos eram concedidos aos fazendeiros a taxa de $6 \%$ e captados a uma taxa que variava entre $8 \%$ e $12 \%$ ao ano.

Em primeiro lugar, a taxa de juros cobrada pelos BCRs não era efetivamente de $6 \%$ ao ano. Esses bancos faziam o desconto da letra dos fazendeiros a uma taxa de $6 \%$, entretanto, como o dinheiro era entregue em parcelas mensais, e eles seguravam consigo o restante, a taxa real de juros era maior. Em segundo lugar, a Incorporadora pôs em operação um mecanismo de desconto e redesconto de títulos comerciais que se explica da seguinte maneira.

\footnotetext{
${ }^{373}$ Idem, p. 48.

${ }^{374}$ Idem, Lista de descontos sem indicação de página.
} 
Uma parte dos recursos captados era remetida aos BCRs para o pagamento das parcelas devidas aos fazendeiros e o restante permanecia no caixa da Incorporadora. Assim, entre a captação dos recursos e a sua total remessa aos Bancos de Custeio havia um intervalo no qual a Incorporadora aplicava esse dinheiro em desconto de letras de curto prazo, geralmente com taxas maiores.

O resultado da operação com títulos comerciais compensava a diferença entre a taxa de juro paga na captação e a taxa cobrada para custeio agrícola, que na realidade era superior a $6 \%$. Essas operações foram descritas no relatório do processo de falência da Sociedade Incorporadora.

Figura 6: Funcionamento em conjunto: Sociedade Incorporadora, Bancos de Custeio Rural e mercado de letras de câmbio

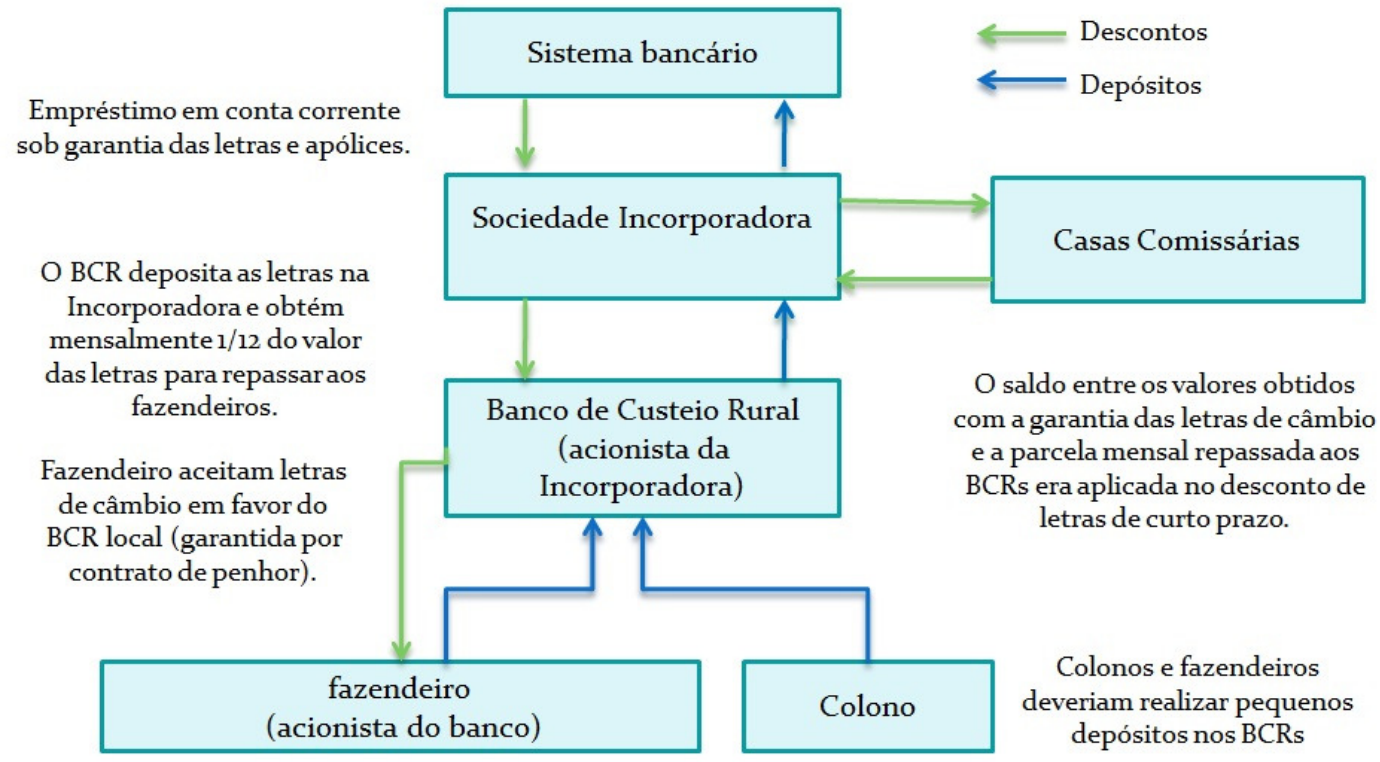

Fontes: Atas e Estatutos dos Bancos de Custeio Rural e Processo de Falência da Sociedade Incorporadora

Entretanto, há ainda um fator a ser observado, como os fazendeiros contratavam os empréstimos e pagavam $6 \%$ sobre o valor integral das letras, mas recebiam menos de $8 \%$ em doze parcelas mensais, o valor realmente pago pelos fazendeiros aos bancos de custeio era maior.

Mas o que mais nos interessa aqui é como esses bancos demonstraram enorme fragilidade em relação às oscilações do comércio cafeeiro. Eles foram concebidos como alternativa ao crédito comercial, devendo suas atividades serem apartadas completamente das operações de caráter comercial, no entanto, eles acabaram falindo em decorrência da quebra de duas firmas comerciais com a qual assumiram elevados compromissos. Por outro lado, eles foram organizados para funcionar como caixas rurais de poupança e 
empréstimos, que deveriam cumprir uma função considerada muito relevante pelos contemporâneos, que era a atração das pequenas poupanças que, acreditava-se, estavam retidas nas mãos dos colonos e que permaneciam sem aplicação reprodutiva por longos períodos. Entretanto, sua captação de depósitos, quando comparada ao volume do crédito concedido por eles e, principalmente, quando comparada à relação empréstimos/depósitos apresentada pelos bancos comerciais da capital paulista era mínima $^{375}$. Dos 3.686:523\$000 emprestados pelos vinte bancos fiscalizados pela Secretaria da Fazenda em 1910, os mesmos bancos tinham apenas 1.742:854\$000 em depósitos, uma relação de 0,43 dos empréstimos sobre os depósitos. Nesse mesmo ano e de acordo com Flávio Saes, os bancos da Capital paulista haviam concedido 84.965:483\$000 em créditos e atraído depósitos no valor de 86.016:892\$000, ou seja, uma relação de empréstimos sobre depósitos de 0,98 .

Em que pese, entretanto, essas considerações desfavoráveis que acabamos de elencar, os Bancos de Custeio Rural chegaram a emprestar 11 mil contos de réis a fazendeiros no ano de 1912, uma quantia admirável, visto se tratar de $8 \%$ dos empréstimos concedidos pelos bancos nacionais naquele ano ${ }^{376}$. Entretanto, em que pese o seu rápido desenvolvimento, eles desapareceram logo após a falência da Sociedade Incorporadora. $\mathrm{O}$ seu fracasso, por outro lado, não impediu que alguns anos mais tarde essa mesma modalidade voltasse a ser experimentada em São Paulo. Altino Arantes, presidente do estado entre 1916 e 1920, em seu primeiro discurso ao Congresso Legislativo, criticou a atuação dos Bancos de Custeio Rural, ressaltando, entretanto, a importância de se resgatar a ideia das "caixas rurais" como mecanismo de financiamento da lavoura. Dizia o presidente que:

O desastre não deve, entretanto, desanimar aos particulares e aos poderes públicos. Convém insistir no restabelecimento desses institutos, agora expurgados dos vícios e falhas que ocasionaram o malogro dos primeiros ensaios. As cooperativas agrícolas ou caixas rurais, constituídas pela associação dos lavradores e ligadas a um estabelecimento central, que exerça sobre elas relativa superintendência e lhes proporcione os fundos necessários para o seu regular funcionamento; representam elementos de maior eficácia na expansão do crédito agrícola.

Em 1918, Altino Arantes elaborou um novo modelo de financiamento que entraria em operação a partir de 1919 e que funcionaria da seguinte forma: as recém- criadas

${ }^{375}$ Cf. SAES, 1986, op. cit.

${ }^{376}$ Idem, ibdem, p. 222. 
Caixas Econômicas Paulistas (futura Caixa Econômica Estadual) constituir-se-iam em diversas agências espalhadas pelo interior do estado onde deveriam captar os depósitos das localidades. Esses recursos, por sua vez, seriam depositados no Banco de Crédito Hipotecário e Agrícola do Estado de São Paulo que, por sua vez, distribuiria os mesmos recursos aos Bancos de Crédito Popular, concebidos como cooperativas de crédito para realizar empréstimo sob penhor, não apenas à lavoura cafeeira, mas também aos criadores de gado e aos demais fazendeiros. Infelizmente não contamos com análises historiográficas das Caixas Econômicas Paulistas e dos Bancos de Crédito Popular, embora possamos identificar sua rápida disseminação pelo estado nos anos seguintes ${ }^{377}$.

${ }^{377}$ Cf. SÃO PAULO. Mensagem apresentada ao Congresso Legislativo, em 14 de julho de 1916, pelo Dr. Altino Arantes, presidente do Estado de São Paulo; CAMPOS, Lycurgo do Amaral. Caixas economicas aulistas: Leis decretos, circulares, avisos, communicados, portarias instruções, contabilidade. São Paulo: s/n, 1936. 


\section{CONCLUSÃo}

Buscamos demonstrar ao longo deste trabalho como a transformações estrurais e conjunturais da economia cafeeira na passagem do século XIX para o XX modificaram a demanda por recursos para o financiamento da cafeicultura que culminaram em experiências bem e mal sucessedidas no sentido de equacionar o sistema de crédito às novas características do sistema produtivo. Em primeiro lugar, o aumento da demanda por recursos para o custeio das plantações exigiu maior esforço financeiro por parte dos agentes envolvidos no comércio tradicionalmente envolvidos no financiamento das safras. Por outro lado, enquanto uma parte considerável do financiamento da produção era fornecida pelo comércio comissário tal característica potencializava os efeitos das oscilações dos preços sobre a oferta de crédito, visto que os comissários regulavam os adiantamentos sobre a safra mediante sua expectativa em relação as cotações do produto. Desse modo, em 1896, a possibilidade de uma baixa acentuada dos preços causou uma severa retração dos adiantamentos concedidos pelo comercio comissário que, por um lado, gerou grande descontentamentio por parte dos fazendeiros e, por outro, permitiu às casas exportadoras e aos agentes locais tomarem parcelas da clientela das firmas comissárias, gerando diversas fissuras no frágil equilíbrio das forças sociais e políticas do estado.

Da parte dos fazendeiros, a desconfiança quanto o fornecimento de crédito pelo comércio comissário e a contração dos preços nos anos seguintes aumentaria a insatisfação dos fazendeiros em relação ao sistema de crédito, principalmente daqueles proprietários mais dependentes do financiamento externo. Comissários e fazendeiros passaram rediscutir o modelo de financiamento da cafeicultura, a política agrícola e o papel do Estado no desenvolvimento da economia cafeeira que culminariam na política de valorização do café imoplementada em meados de 1906. No que diz respeito ao crédito, os governos estadual e federal passaeram sofrem intensa pressão no sentido de criar ou subsidiar instituições de crédito que tornassem o financiamento agrícola independente do crédito comercial - o chamado crédito agrícola.

Como a crise não afetava apenas a camada de fazendeiros mais dependente de financiamento, mas também as próprias firmas comissárias, diversas propostas de reorganização do sistema de crédito surgiram no intervalo de tempo entre 1896 a 1906, buscando atender os diversos interesses em jogo, desde a criação de bancos agrícolas que livrassem os fazendeiros do crédito comercial até a criação de um banco público que 
fornecesse aos comissários os recursos para a manutenção do sistema tradicional de financiamento e proteção contra o comércio exportador. Um dos principais pontos de divergência dizia respeito à legitimidade da intervenção do governo na organização do crédito, questão que acompanhava a própria legitimidade da manipulação dos preços via regulação e que resultaria na aprovação do Convênio de Taubaté e na execução do Plano de Valorização. Várias dessas propostas surgiram conjuntamente em 1896 e evoluíram, ao longo dos dez anos seguintes, para a política agrícola adotado em 1906.

A recusa do PRP em adotar qualquer tipo de intervenção atraiu diferentes níveis de insatisfação entre os diversos setores econômicos e sociais envolvidos na exportação do café, esse estado de insatisfação foi explorado politicamente com grande sucesso pelos opositores do partido e do governo republicano, fazendo com que as críticas ao governo do PRP passassem a se articular em torno da questão do socorro à lavoura, opondo-se aqueles que se diziam defensores dos "interesses da lavoura", ou seja, o interesse "legítimo" dos fazendeiros de menor poder econômico e daqueles que mesmo sendo grandes permaneciam alijados do poder político e, de outro lado, aquele setor mais envolvido com as atividades não agrárias do complexo cafeeiro, não apenas o interesse da fração comercial da burguesia cafeeira, mas, principalmente, do financista ou "capitalista" como era denominado à época o indivíduo que possuía aplicações em diversos setores. Para os partidários da "Lavoura" o interesse do "capitalista", ou melhor, o interesse do estrato superior do capital cafeeiro estaria alojado na cúpula do Partido Republicano Paulista.

Era contra a suposta representação desses interesses pelos dirigentes do PRP que nos congressos agrícolas, as lideranças opositoras (monarquistas, jacobinos e republicanos dissidentes) defendiam a criação do Partido da Lavoura, uma agremiação que buscava vencer de cooptação do governo e arregimentar para o campo oposicionista os fazendeiros insatisfeitos com os efeitos da crise econômica.

Paralelamente, naquele mesmo período, assistia-se no continente europeu à rápida expansão das cooperativas de crédito que experimentaram enorme sucesso ao incorporar os camponeses isolados em suas localidades ao sistema comercial de crédito. Esse modelo de instituição de crédito havia se disseminado na Alemanha e na França devido o empenho da igreja católica em agrupar os agricultores prejudicados pela crise agrária das últimas décadas do século XIX contra o liberalismo econômico, um movimento mais amplo de resistência ao liberalismo e reafirmação dos valores agrários - o chamado 
"agrarismo" - encontrava, ao mesmo tempo, no sindicalismo agrícola e na propagação das cooperativas rurais de crédito um dos principais meios de proteção do interesse agrário diante do liberalismo econômico.

O cooperativismo de crédito foi assimilado no Brasil de acordo com as diversas vertentes existentes na Europa, desde o sindicalismo católico e nobiliárquico de matiz alemão (como foi o caso das caixas agrícolas fundadas pela colônia teutônica no Rio Grande do Sul) e francês (como o sindicalismo e o cooperativismo defendidos pela igreja católica no Rio de Janeiro), passando pelo agrarismo republicano francês (representado pela Sociedade Brasileira de Agricultura - SNA) até uma acepção mais utilitária das instituições cooperativas, como foi o caso dos Bancos de Custeio Rural, inspirados, em grande parte, na experiência dos bancos italianos do tipo Luzzatti, que mesclavam mecanismos dos bancos populares alemães (de orientação liberal) aos das caixas católicas do tipo Raiffeisen, expurgados os seus preceitos doutrinários e a orientação política e contestatória.

Uma das formas de propagação do cooperativismo em São Paulo ocorreu como consequência das discussões em torno da criação de associações de classe de fazendeiros que estavam inspiradas nas sociedades rurais francesas. Essa vertente tinha como estratégia a criação de caixas rurais em torno de sindicatos agrícolas locais que, por sua vez, formariam uma grande federação sindical agrícola. Apesar do apoio inicial dispensado pelo governo paulista, a organização de tais associações passou, rapidamente, a ser desestimulada pelo próprio governo temeroso do rumo contestatório que os congressos agrícolas acabaram trilhando. Mas, por outro lado, havia entre as lideranças políticas do PRP muitos defensores do cooperativismo de crédito que viam nessas associações uma forma de regularizar o crédito agrícola sem intervir diretamente na forma de subvenções a bancos agrícolas e, principalmente, sem alteração da política monetária vigente. Desse modo, buscou-se adotar um modelo de cooperativas de crédito que permanecesse desvinculado da organização de associações de classe, limitando-se os riscos políticos advindos do associativismo ao mesmo tempo em que se refutava a alteração da política monetária.

Em 1900, como resultado das alianças que elegeram Rodrigues Alves para a presidência estadual, o PRP passou a assumir parte das reivindicações dos fazendeiros no sentido de intervir e combater a crise, pondo em prática, ao mesmo tempo, um programa de cooptação das lideranças divergentes e transferindo para dentro da estrutura 
administrativa estadual o lócus dos debates sobre os temas agrários, dessa maneira foram criados o Serviço Agronômico do Estado de São Paulo, o qual, entre outras funções, passou a conduzir a realização das assembleias municipais de fazendeiros. Ao mesmo tempo apoiou a organização da Sociedade Paulista de Agricultura, uma entidade dirigida por grandes fazendeiros e com subvenção estatal que passaria a conduzir os debates sobre política agrícola de acordo com os interesses do estrato superior do capital cafeeiro. Desse modo, separava-se o encaminhamento das questões agrárias em duas esferas: a primeira delas no âmbito dos pequenos e médios fazendeiros que, isolados nas localidades, tinham suas reivindicações conduzidas pelo inspetor do Serviço Agronômico que controlava as reuniões das comissões municipais de agricultura; enquanto isso, as questões de maior relevância para o grande capital cafeeiro passavam a ser conduzidas pela Sociedade Paulista de Agricultura. Realizações que constribuiram para diminuir os comícios agrícolas locais e os congressos agrícolas que, via de regra, servia de palanque aos opositores do regime.

O processo de pacificação política do estado de São Paulo foi concluído no final de 1906, quando se deu o chamado "congraçamento" das alas dissidentes e a incorporação das lideranças monarquistas e "jacobinas" na administração estadual e nos quadros do PRP. Ao mesmo tempo, como resultado da conciliação dos interesses e do agravamento da crise cafeeira, foi colocado em prática o plano de valorização, que desde 1902, vinha sendo encaminhado pela SPA e organizou-se um sistema de crédito agrícola, composto por um banco hipotecário destinado aos empréstimos de longo prazo que começaria a funcionar em 1909 (o Banco de Crédito Hipotecário e Agrícola do Estado de São Paulo) e o incentivo aos Bancos de Custeio Rural, organizados pela Sociedade Incorporadora, entidade que tinha em seu quadro diretivo a representação das lideranças que vinham se opondo à política estadual, mas que agora compartilhavam da liderança do governo e do partido dos republicanos paulistas.

Na constituição dos Bancos de Custeio Rural, observou-se o empenho do governo paulista em suprimir os espaços de possíveis manifestações de divergências. Desse modo, embora a lei $\mathrm{n}^{\circ} 866$, de 7 de abril de 1903, houvesse autorizado o governo estadual a auxiliar na organização de cooperativas de crédito, constituídas sob a forma de sindicatos agrícolas, o modelo que acabaria recebendo auxílios seria aquele desenvolvido por Jacintho de Barros, que consistia na organização de bancos de caráter mutual, mas constituídos como sociedade anônimas e cujos objetivos deveriam se restringir à 
concessão de empréstimos aos associados, sem nenhuma conotação de associações de classe.

Os Bancos de Custeio Rural experimentaram grande sucesso ao realizar a intermediação entre os fazendeiros e o sistema bancário paulista. O seu modo de operação havia permitido ao conjunto desses bancos concentrar as garantias pignoratícias de pequenos fazendeiros em poucas operações de crédito junto aos bancos comerciais da capital paulista. Em conjunto, eles chegaram a emprestar valor equivalente a $10 \%$ dos empréstimos concedidos pelo sistema bancário entre 1909 e 1913, o que é extremamente relevante se considerarmos que tais operações não atraíam a atenção dos bancos sediados na capital paulista.

A Sociedade Incorporadora que contrariou seus estatutos para conceder crédito às casas comissárias, tornara-se extremamente dependente dos sucessos desse ramo de comércio. No entanto, o valor enganosamente baixo das taxas cobradas, 6\% ao ano, apenas se sustentava porque os recursos não eram recebidos pelos fazendeiros em sua totalidade, mas apenas em parcelas mensais de 1/12, enquanto o saldo restante era utilizado na concessão de crédito a comissários de café pelo desconto de suas letras, quando se empregava taxas muito maiores. A Sociedade Incorporadora e os Bancos de Custeio Rural tinham como opção levantar no setor bancário apenas os valores requeridos para o financiamento agrícola, repassando aos fazendeiros os mesmos valores com certo acréscimo, era desse modo que estava colocada a proposta de Jacintho de Barros, no entanto, optou-se por realizar operações de caráter comercial alavancadas com a caução dos títulos de penhor dos fazendeiros associados que estavam em poder dos Bancos de Custeio.

A descoberta de fraudes cometidas pelos diretores da Sociedade Incorporadora e a alavancagem para a realização de operação de caráter comercial foram apontadas pelos síndicos da massa falida como os fatores responsáveis pela falência, entretanto, o insucesso das experiências com o crédito cooperativo e o pífio desenvolvimento dessa modalidade de instituição no Brasil nos sugere outros fatores que nos ajudam a explicar o fracasso dos Bancos de Custeio Rural.

Nos países onde esse tipo de instituição obteve grande sucesso, como Alemanha, França e Bélgica, a economia agrícola diferia radicalmente da economia agroexportadora. $\mathrm{Na}$ Europa, a atividade agrícola era realizada predominantemente por pequenos 
proprietários e arrendatários que exploravam uma enorme variedade de culturas agrícolas e atividades pastoris, tal característica conferia uma demanda muito diversificada de crédito ao longo do ano, enquanto a formação irregular de saldos monetários ociosos possibilitava às redes de caixas rurais organizadas nacionalmente transferir os recursos que permaneciam sem utilização em determinados setores àqueles que demandavam esses recursos, complementando-se tais operações com aplicações e captações ao sistema de crédito convencional.

Por outro lado, a economia agroexportadora é marcada pela especialização monocultora, onde a demanda por crédito e a disponibilidade de saldos ociosos ocorrem praticamente ao mesmo tempo, concentrando-se no período da colheita, quando afluía para o interior do estado uma enorme soma de recursos. O modo de organização dos Bancos de Custeio acentuava ainda mais os efeitos causados pelo sentido agroexportador daquela economia. A constituição desses bancos refletia diretamente a pressão exercida pelo setor agrícola mais afetado pela crise dos preços do café - os cafeicultores, desse modo, os Bancos de Custeio estavam voltados exclusivamente ao atendimento dos produtores de café e ignoravam, por exemplo, as propriedades voltadas à agricultura de abastecimento, cana-de-açúcar e algodão, além da pecuária, setores que embora fossem subordinados ao café ou tivessem menor relevância econômica não contavam com um aparato de financiamento comercial tão organizado como aquele representado pelos comissários de café e, certamente, demandavam grande quantidade de recursos para financiamento e que poderiam ser atendidos pelos Bancos de Custeio Rural. No entanto, a organização desses bancos como associações exclusivas de fazendeiros de café tinha um alcance muito limitado do ponto de vista da otimização dos recursos empregados, mesmo estando federados estadualmente, eles tinham um alcance extremamente limitado. Como todos os mutuários eram fazendeiros de café, a demanda por empréstimos mantinha-se concentrada nos mesmos períodos e, provavelmente, o mesmo ocorria em relação aos recursos disponíveis para depósito e aplicações. Em tal contexto, as únicas possibilidades de se captar os recursos demandados eram, de um lado, a poupança dos colonos, recursos que se existiam realmente em grande monta, os trabalhadores não confiaram em depositar nos BCRs e, por outro lado, a captação de empréstimos junto aos bancos tradicionais, nesse caso, os Bancos de Custeio apenas distribuíam os recursos já disponíveis no sistema bancário, contribuindo muito pouco para multiplicação dos meios de pagamento. Na verdade, no que diz respeito ao efeito multiplicador, a atuação dos 
BCRs como meros correspondentes dos bancos comerciais não apresentava uma alternativa realmente transformadora em relação aos adiantamentos concedidos pelos comissários, na medida em que estes também eram correspondentes do crédito bancário.

Tendo discutido esses fatores, podemos retomar agora a determinação imposta pelos estatutos da Sociedade Incorporadora de apenas operar no âmbito dos Bancos de Custeio Rural. Essa determinação exigia que a instituição ficasse restrita ao financiamento da cafeicultura, o que limitava o seu próprio papel enquanto agente distribuidor dos recursos entre os diversos bancos locais. Entretanto, ao descontar letras de comerciantes, embora contrariando suas diretrizes, a Incorporadora encontrou uma forma de diversificar suas operações, embora a concentração dos créditos em um mesmo ramo de atividade, o comércio comissário, possa ter anulado o efeito doversificador de tais operações, aumentado a sua vulnerabilidade diante das oscilações do mercado de café.

O objetivo dos Bancos de Custeio era prover a lavoura de um meio de financiamento constante e, ao mesmo tempo, independente das especulações no mercado de crédito. Porém, a falência da Sociedade Incorporadora demonstrou como o sistema de crédito era determinado por operações de curto prazo e risco elevado. A própria Incorporadora estava envolvida nesse tipo de atividade, que não era apenas acessória, pois que sustentava as operações com o penhor agrícola. Por outro lado, o período de funcionamento dos Bancos de Custeio foi de grande estabilidade nos preços do café e eles faliram na primeira crise financeira que enfrentaram, ou seja, no momento em que mais se poderiam fazer necessários.

Por fim, o que gostaríamos de demonstrar, à guisa de conclusão, é que a compreensão a respeito da origem, funcionamento e importância dos Bancos de Custeio Rural só pode ser concluída depois de se ter discutido o compasso das disputas políticas no interior do complexo cafeeiro, assim como, essas mesmas disputas não poderiam ser compreendidas apenas pela observação do processo partidário. Nesse caso, buscamos situar a constituição dos Bancos de Custeio Rural no quadro das disputas pelo controle do processo político no estado e demonstrar como, por sua vez, essas disputas estavam pautadas pela dinâmica de acumulação do capital cafeeiro e pela crise dos preços do café, que suscitava contradições latentes, mas que não chegaram a se constituir em verdadeiros antagonismos, visto que acabaram abafadas pelo "congraçamento" político e pelas 
medidas econômicas de combate à crise, das quais os Bancos de Custeio Rural fazem parte, assim como o BCHAESP e o próprio Plano de Valorização do Café. 
Acervos Consultados

Acervo Histórico da Assembleia Legislativa do Estado de São Paulo (ALESP)

Arquivo Público do Estado de São Paulo (APESP)

Arquivo Municipal de Jaboticabal (AMJ)

Arquivo Geral do Tribunal de Justiça do Estado de São Paulo (TJSP)

Arquivo e Biblioteca do Instituto de Estudos Brasileiros (IEB)

$1^{\circ}$ Registro de Imóveis da capital

Biblioteca da Faculdade de Direito (FD-USP)

Biblioteca da Faculdade de Filosofia, Letras e Ciências Humanas, USP (FFLCH-USP)

Biblioteca da Faculdade de Economia, USP (FEA-USP)

Biblioteca Nacional (BN)

Biblioteca Redentorista de Juiz de Fora (BRJF)

Museu Republicano, USP (MR-USP)

Museu Paulista, USP (MP-USP)

Acervos digitalizados e disponíveis na internet

ALESP. Legislação (Pesquisa). Disponível em: http://www.al.sp.gov.br/doc-e-

informacao/legislacao-pesquisa

Center for Research Libraries. Brazilian Government Documents. (CRL-Chicago).

Disponível em: http://www.crl.edu/brazil

Fundação Biblioteca Nacional. Hemeroteca Digital Brasileira. (HD-BN). Disponível

em: http://hemerotecadigital.bn.br/

Fundação SEADE. Biblioteca digital. Disponível em: http://www.seade.gov.br/

Memória estatística do Brasil: no Acervo da Biblioteca do Ministério da Fazenda no Rio de Janeiro. Disponível em: memoria.org.br

Senado Federal. Portal Legislação. Disponível em:

http://legis.senado.gov.br/sicon/index.jsp?action=LegislacaoTextual

Documentos Analisados

Periódicos

O Commercio de São Paulo, janeiro de 1914 a março de 1915 (FD-USP)

O Estado de São Paulo, 1914-1915 (APESP)

Correio Paulistano (HD-BN)

A Capital, $1^{\circ}$ trim. de 1914 (APESP)

A Platéia, $1^{\circ}$ trim. de 1914 (APESP)

Diário Popular, $1^{\circ}$ trim. de 1914 (APESP)

O Alpha, (Rio Claro), $1^{\circ}$ trim. de 1914 (APESP)

O Atalaya (Jaboticabal), janeiro de 1900 a dezembro de 1907 (AMJ)

O Paiz

Diario Official do Estado de São Paulo, 1903-1916 (FD e APESP, busca por números específicos)

Almanaques, Anuários e Revistas

Almanak Laemmert. Annuario administrativo, agricola, profissional, mercantil $e$ industrial dos Estados Unidos do Brasil e indicador para 1911-1912. São Paulo: Typ. AlmanakLaemert, 1911. 
A Lavoura, Boletim da Sociedade Nacional da Agricultura, 1906 a 1909.

Revista agrícola. Sociedade Pastoril e Agrícola. São Paulo: [s.n.], 1895-1907 (MR-USP)

Retrospecto Commercial do Jornal do Commercio, 1896. Rio de Janeiro. Typ. do Jornal do Commercio, 1897.

Retrospecto Commercial do Jornal do Commercio, 1897. Rio de Janeiro. Typ. do Jornal do Commercio, 1898.

Retrospecto Commercial do Jornal do Commercio, 1898. Rio de Janeiro. Typ. do Jornal do Commercio, 1899.

Anuário Estatístico do Estado de São Paulo (FFLCH-USP/FE-USP)

BRASIL. MINISTERIO DA AGRICULTURA. Annuario estatistico do Brasil, $1^{o}$ anno, (1908-1912), volume II, Economia e Finanças. Rio de Janeiro: Typ. da Estatistica, 1917.

SÃO PAULO. REPARTIÇÃO DE ESTATÍSTICA E ARCHIVO DO ESTADO DE S. PAULO. Relatorio do anno de 1896 apresentado em 30 de setembro de 1897 ao Cidadão Dr. Antonio Dino da Costa Bueno, Secretário do Estado dos Negócios do Interior, pelo Dr. Antonio de Toledo Piza, Director. São Paulo: s/n., 1897.

Annuario estatistico do estado de São Paulo, 1901. São Paulo: Typ. Do Diario Official., 1904. Annuario estatistico do estado de São Paulo, 1902. São Paulo: Typ. Do Diario Official., 1905.

Annuario estatistico do estado de São Paulo, 1903. São Paulo: Typ. Espindola \& Comp., 1906.

Annuario estatistico do estado de São Paulo, 1906. Estatistica Econômica e Moral. Vol. II, São Paulo: Typ. Espindola \& Comp., 1909.

Annuario estatistico do estado de São Paulo, 1907. Estatistica Econômica e Moral. Vol. II, São Paulo: Duprat \& Comp., 1910.

Annuario Estatistico do Estado de São Paulo, 1908. Estatistica Econômica e Moral. Vol. II, São Paulo: Typ. do Diario Official, 1911.

Annuario Estatistico do Estado de São Paulo, 1909. Estatistica Econômica e

Moral. Vol. II. São Paulo: Vanorden, 1910.

Annuario Estatistico do Estado de São Paulo, 1910. Estatistica Econômica e

Moral. Vol. II. São Paulo: Duprat \& Comp., 1912.

Annuario Estatistico do Estado de São Paulo, 1911. Estatistica Econômica e

Moral. Vol. II. São Paulo: Rothschild, 1913.

Annuario Estatistico do Estado de São Paulo, 1912. Estatistica Econômica e

Moral. Vol. II. São Paulo: Typ. Do Diario Official, 1914.

Annuario estatistico do Estado de São Paulo, 1913. Estatistica Econômica e

Moral. Vol. II. São Paulo: Typ. Do Diario Official, 1915.

Annuario estatistico do estado de São Paulo, 1914. Estatistica Econômica e

Moral. Vol. II. São Paulo: Typ. Do Diario Official, 1916.

Relatórios de Secretarias do Estado de São Paulo (FE-USP/MP-USP/FFLCH-USP)

SÃO PAULO. SECRETARIA DA FAZENDA. Relatorio do Anno de 1899 Apresentado ao Coronel Fernando Prestes de Albuquerque, Presidente do Estado, Pelo Doutor João Baptista de Mello Peixoto, Secretario da Fazenda. São Paulo: Diario Official, 1900. 
Relatorio Apresentado ao Dr. Francisco de Paula Rodrigues Alves, Presidente do Estado, Pelo Dr. Francisco de Toledo Malta, Secretario da Fazenda, Anno de 1900. São Paulo: Diario Official, 1901.

Relatorio Apresentado ao Dr. Domingos Corrêa de Moraes, Vice-Presidente do Estado, Pelo Dr. Francisco de Toledo Malta, Secretario da Fazenda, Anno de 1901. São Paulo: Diario Official, 1902.

Relatorio Apresentado ao Exm. Sr. Dr. Domingos Correa de Moraes, vicepresidente do estado de São Paulo pelo Dr. Firmiano de Moraes Pinto, Secretario de Estado dos Negocios da Fazenda. São Paulo Diario Oficial 1903.

Relatorio Apresentado ao Exmo. Sr. Dr. Jorge Tibiriçá, Presidente do Estado, Pelo Dr. M. J. de Albuquerque Lins, Secretario da Fazenda, Anno de 1904. São Paulo: Diario Official, 1905.

Relatorio Apresentado ao Dr. Jorge Tibiriçá, Presidente do Estado, Pelo Dr. M. J. de Albuquerque Lins, Secretario da Fazenda, 1905. São Paulo: Diario Official, 1906.

Relatorio Apresentado [...] Secretario da Fazenda, 1907. São Paulo: Typ. do Diario Official, 1908.

Relatorio Apresentado ao Dr. Jorge Tibiriçá, Presidente do Estado, Pelo Dr. Olavo Egydio de Souza Aranha, Secretario da Fazenda, 1907. São Paulo: Diario Official, 1908.

Relatorio Apresentado ao Dr. Manuel Joaquim de Albuquerque Lins, Presidente do Estado, Pelo Dr. Carlos Augusto Pereira Guimarães, Secretario Interino da Fazenda, 1910. São Paulo: Typ. Casa Garraux, 1911.

Relatorio [...] Secretario Interino da Fazenda, 1910. São Paulo: Typ. Casa Garraux, 1911.

Relatório apresentado ao Exmo. Snr. Dr. Francisco de Paula Rodrigues Alves pelo Dr. Raphael de Abreu Sampaio Vidal, Secretário da Fazenda: exercício de 1913. São Paulo, Typ. Casa Garraux, 1916.

Relatório apresentado ao Exmo. Snr. Dr. Francisco de Paula Rodrigues Alves pelo Dr. Raphael de Abreu Sampaio Vidal, Secretário da Fazenda: exercício de 1914. São Paulo, Typ. Casa Garraux, 1916.

Relatório apresentado ao exmo. Snr. Dr. Altino Arantes presidente do Estado pelo Dr. Jose Cardoso de Almeida, Secretário da Fazenda: exercício 1915. São Paulo, Typ. Casa Garraux, 1916.

Indice de Leis e Decretos da Secretaria da Fazenda de 1899 a 1933. São Paulo:

Typ. Bancaria, 1934.

SÃO PAULO. Repartição de Estatistica e Arquivo do Estado. Annuario Estatistico do Estado de São Paulo, 1912. Estatísticas Economica e Financeira. Vol. II, São Paulo: Typ. Do Diario Official, 1914.

SÃO PAULO. SECRETARIA DA AGRICULTURA. Relatório de 1896 apresentado ao Dr. Manoel Ferraz de Campos Salles, presidente do estado, pelo Dr. Alvaro Augusto da Costa Carvalho, Secretário dos Negócios da Agricultura, Commercio e Obras Públicas. São Paulo Espindola, Siqueira 1897.

Relatório de 1897 apresentado ao Dr. Francisco de Assis Peixoto Gomide, VicePresidente do Estado, pelo Dr. Firmiano M. Pinto, Secretário dos Negócios da Agricultura, Commercio e obras Públicas. São Paulo: Typ. Espinola, 1898.

Relatório correspondente ao anno de 1898, apresentado ao Presidente do Estado, Coronel Fernando Prestes de Albuquerque, pelo Dr. Alfredo Guedes, Secretario da Agricultura. São Paulo Typ. do Diario Official 1899. 
Relatorio apresentado ao Dr. Francisco de Paula Rodrigues Alves, Presidente do Estado pelo Dr. Antonio Candido Rodrigues, Secretario da Agricultura, Anno de 1900. São Paulo: Diario Official, 1901.

Relatório apresentado ao Dr. Jorge Tibiriçá, Presidente do Estado, pelo Dr. Carlos Botelho, Secretario da Agricultura: anno de 1906. São Paulo: Rothschild \& Co., 1907.

Relatorio Apresentado ao Dr. M. J. Albuquerque Lins, Presidente do Estado, Pelo Dr. Antonio Candido Rodrigues, Secretario da Agricultura, Anno de 1908. São Paulo: Typ. Brasil de Rothschild, 1909.

Relatorio Apresentado ao Dr. Manuel Joaquim de Albuquerque Lins, Presidente do Estado, Pelo Dr. Olavo Egydio de Souza Aranha, Secretario da Fazenda, 1909. São Paulo: Typ. Casa Garraux, 1910.

Relatorio Apresentado ao Dr. Manuel Joaquim de Albuquerque Lins, Presidente do Estado, Pelo Dr. Carlos Augusto Pereira Guimarães, Secretario Interino da Fazenda, 1910. São Paulo: Typ. Casa Garraux, 1911.

Relatorio Apresentado ao Exmo. Sr. Dr. Francisco de Paula Rodrigues Alves, Presidente do Estado, Pelo Dr. Joaquim Miguel Martins de Siqueira, Secretario Interino da Fazenda, 1912. São Paulo: Typ. Casa Garraux, 1913.

Relatório apresentado ao Exmo. Snr. Dr. Francisco de Paula Rodrigues Alves pelo Dr. Raphael de Abreu Sampaio Vidal, Secretário da Fazenda: exercício de 1913. São Paulo, Typ. Casa Garraux, 1914.

Relatorio Apresentado ao Exmo. Snr. Dr. Francisco de Paula Rodrigues Alves, Presidente do Estado de São Paulo, Pelo Dr. Raphael de Abreu Sampaio Vidal, Secretario da Fazenda, Exercicio de 1914. São Paulo: Typ. Casa Garraux, 1915.

Relatório apresentado ao exmo. Snr. Dr. Altino Arantes presidente do Estado pelo Dr. Jose Cardoso de Almeida, Secretário da Fazenda: exercício 1915. São Paulo, Typ. Casa Garraux, 1916

Almanach da Secretaria de Estado dos Negócios da Agricultura, Commercio e Obras Públicas do estado de São Paulo para o anno de 1917. São Paulo: Typ. Brasil, 1917.

Relatorio Apresentado ao Exmo. Snr. Dr. Altino Arantes, Presidente do Estado, Pelo Dr. José Cardozo de Almeida, Secretario da Fazenda e do Thesouro, Exercicio de 1918. São Paulo: Garraux, 1919.

Indice de Leis e Decretos da Secretaria da Fazenda de 1889 a 1933. São Paulo:

Typ. Bancaria, 1934.

Mensagens Enviadas pelos Presidentes do Estado de São Paulo ao Congresso Legislativo (CRL-Chicago)

SÃO PAULO. PRESIDÊNCIA DO ESTADO. Mensagem enviada ao Congresso Legislativo a 7 de abril de 1897 por Campos Salles Presidente do Estado. São Paulo: Typ. do Diario Official, 1897.

Mensagem apresentada ao Congresso Legislativo a 7 de abril de 1902, pelo Dr. Domingos Correa, Presidente do Estado.

Mensagem enviada ao Congresso Legislativo a $1^{o}$ de julho de 1903 por Domingos Correa de Moraes, Vice-Presidente do Estado.

Mensagem Enviada ao Congresso Legislativo a 5 de março de 1903 por Bernardino de Campos, Presidente do Estado. São Paulo: Typ. Diario Oficial, 1903. 
Mensagem enviada ao Congresso Legislativo a 7 de abril de 1904 pelo Dr. Bernardino de Campos, Presidente do Estado. São Paulo: Typ. Diario Official, 1904 Mensagem enviada ao Congresso Legislativo a 14 de julho de 1905 pelo Dr. Jorge Tibiriça, Presidente do Estado.

Mensagem enviada ao Congresso Legislativo a 14 de julho de 1906 pelo Dr. Jorge Tibiriça, Presidente do Estado.

Mensagem enviada ao Congresso Legislativo a 14 de julho de 1908 pelo Dr. M. J. Albuquerque Lins, Presidente do Estado.

Mensagem enviada ao Congresso Legislativo a 14 de julho de 1909 pelo Dr. M. J. Albuquerque Lins, Presidente do Estado.

Mensagem enviada ao Congresso Legislativo a 14 de julho de 1913 pelo Dr. F. de Paula Rodrigues Alves, Presidente do Estado.

Mensagens Apresentadas ao Congresso de São Paulo pelos Presidentes em exercício, desde a Proclamação da República até o anno de 1916. São Paulo: Typ. Do Diario Official, 1916

Mensagem apresentada ao Congresso Legislativo, em 14 de julho de 1916, pelo Dr. Altino Arantes, presidente do Estado de São Paulo.

Mensagem enviada ao Congresso Legislativo a 14 de julho de 1917 pelo Dr. Altino Arantes, Presidente do Estado.

Mensagem enviada ao Congresso Legislativo a 14 de julho de 1918 pelo Dr. Altino Arantes, Presidente do Estado.

Diário Oficial do Estado de São Paulo

Diario Official do Estado de S. Paulo. 1/2/1907 "Banco de Custeio Rural de Jaboticabal. Acta da Assemblea Geral Constituinte a sete de janeiro de mil novecentos e sete".

Diario Official do Estado de S. Paulo. 18/2/1907, "Estatutos do Banco de Custeio Rural de Pindamonhangaba".

Diario Official do Estado de S. Paulo. 12/5/1907, "Estatutos do Banco de Custeio Rural de Ribeirão Bonito".

Diario Official do Estado de S. Paulo. 27/4/1907, "Estatutos do Banco de Custeio Rural de Ribeirão Preto".

Diario Official do Estado de S. Paulo. //1907 Acta da Assemblea Geral Extraordinaria do banco de Custeio Rural de Ribeirão Bonito, em 14 de abril de 1907

Diario Official do Estado de S. Paulo. 27/4/1907 Banco de Custeio Rural de Ribeirão Preto. Acta da Assemblea Geral Extraordinaria em 31 de março de 1907

Documentos dos Poderes Legislativos Federal e Estadual (FD-USP/ALESP)

BRASIL. CAMARA DOS DEPUTADOS. Política econômica: Caixa de conversão (Série Documentos Parlamentares), 1906. Rio de Janeiro: Câmara dos Deputados, 1914.

Politica Economica, Valorisação do Café (Série Documentos Parlamentares), 1908-1915. Rio de Janeiro: Typ. do Jornal do Commercio, de Rodrigues \& C., 1915. v.2.

Politica Economica, Valorisação do Café (Série Documentos Parlamentares), 1895-1906. Rio de Janeiro: Typ. do Jornal do Commercio, 1915, v.1.

Politica economica, valorisação do café (Série Documentos Parlamentares), 1895-1915. Rio de Janeiro: Typ. do Jornal do Commercio, 1915, v. 2. 
SÃO PAULO, CONGRESSO LEGISLATIVO. Synopse dos trabalhos da sessão de 1906. São Paulo: Typ. Correio Paulistano, 1907.

Annaes da Sessão extraordinária e ordinária de 1906. São Paulo: s/n., 1907.

SÃO PAULO. ALESP: ACERVO HISTÓRICO. Projeto n. 7, de 1899, cx 207 "Providencia sobre a criação de uma sociedade, sob a forma annonyma, que terá a seu cargo a criação de um Banco Popular e Caixa Economica do Estado de São Paulo".

Annaes da Sessão extraordinária e ordinária de 1905. São Paulo: s/n., 1906. Annaes da Sessão extraordinária e ordinária de 1906. São Paulo: s/n., 1907.

Projeto n. 5, de 1907, cx 161.

Projeto n. 40, de 1903, cx 60.

Projeto n. 40, de 1903, cx 229.

Projeto n. 5, de 1907, cx 209.

Projeto $s / n$ de 1903. "Providencia sobre os meios de minorar os effeitos da crise cafeeira", cx 60.

Projeto n. 25 de 1902, "Estabelece medidas destinadas a minorar os effeitos da

crise da lavoura de café". cx 54.

Parecer n. 125 de 1903, cx 226.

Parecer 141 de 1906, cx 229.

Tribunal de Justiça do Estado do São Paulo

SÃO PAULO. TRIBUNAL DE JUSTIÇA DO ESTADO DE SÃO PAULO. ARQUIVO GERAL. ARQUIVO GERAL. " 2 o oficial da $1^{\text {a }}$ Vara Commercial de São Paulo", Processo de Fallencia, Sociedade Incorporadora (v. 1), n. 12.504, cx 431 (2 ${ }^{\mathrm{a}}$ Vara Cível, 6 de janeiro de 1914).

" $2^{\circ}$ Oficial da $1^{\text {a }}$ Vara Commercial de São Paulo", Processo de Fallencia, Sociedade Incorporadora (v. 2), n. 12.659 cx 431 (2 ${ }^{\text {a }}$ Vara Cível, 6 de janeiro de 1914).

"2 ${ }^{\circ}$ Oficial da $1^{a}$ Vara Commercial de São Paulo", Reclamação reivindicatórias, caixas 431-7 (2 $2^{\text {a }}$ ara Cível, 6 de janeiro de 1914).

\section{Relatórios Ministeriais (CRL-Chicago)}

BRASIL. MINISTÉRIO DA FAZENDA. Proposta e relatório apresentados á Assembléa Legislativa na terceira sessão da décima nona legislatura pelo Ministro Secretario dos Negocios da Fazenda, José Antonio Saraiva. Rio de Janeiro: Typ. Nacional, 1885.

Relatorio do Ministro da Fazenda, Ruy Barbosa, Em Janeiro de 1891. Rio de Janeiro: Imprensa nacional, 1891.

Annexos ao Relatório apresentado ao Presidente da republica dos Estados Unidos do Brazil pelo Ministro de Estado dos Negócios da Fazenda Francisco de Paula Rodrigues Alves no anno de 1896. Rio de Janeiro: Imp. Nacional, 1896.

Relatório apresentado ao Presidente da República dos Estados Unidos do Brazil pelo Ministro de Estado dos Negócios da Fazenda Bernardino de Campos no anno de 1897. Rio de Janeiro: Imp. Nacional, 1897.

Annexos ao Relatório apresentado ao Presidente da Republica dos Estados Unidos do Brazil, pelo Ministro de Estado dos Negócios da Fazenda Bernardino de Campos no anno de 1897. Rio de Janeiro: Imp. Nacional, 1897. 
Relatório apresentado ao Presidente da República dos Estados Unidos do Brasil pelo Ministro de Estado dos Negócios da Fazenda Bernardino de Campos no anno de 1898. Rio de Janeiro: Imp. Nacional, 1898.

Annexos ao relatório apresentado ao Presidente da República dos Estados Unidos do Brazil, pelo Ministro de Estado dos Negócios da Fazenda Joaquim Murtinho no anno de 1899. Rio de Janeiro: Imp. Nacional, 1899.

Relatorio apresentado ao Presidente da Republica dos Estados Unidos do Brasil pelo Ministro de Estado dos Negocios da Fazenda Joaquim Murtinho, no anno de 1900. Rio de Janeiro, Imp. Nacional, 1900.

Annexo ao Relatório apresentado ao Presidente da República dos Estados Unidos do Brasil, pelo Ministro de Estado dos Negócios da Fazenda Joaquim Murtinho no anno de 1900. Rio de Janeiro: Imp. Nacional, 1900.

Relatorio apresentado ao Presidente da Republica dos Estados Unidos do Brazil pelo Ministro de Estado dos Negocios da Fazenda Joaquim Murtinho no anno de 1901. Rio de Janeiro: Imp. Nacional 1901.

Annexo ao Relatorio apresentado ao Presidente da Republica dos Estados Unidos do Brazil pelo Ministro de Estado dos Negocios da Fazenda Joaquim Murtinho no anno de 1901. Rio de Janeiro: Imp. Nacional, 1901.

Relatório Apresentado ao Presidente dos Estados Unidos do Brasil pelo Ministro de Estado dos Negócios da Fazenda Dr. João Pandiá Calógeras no ano de 1915. Rio de Janeiro: Imprensa Nacional, 1915.

BRASIL. MINISTRO DA INDÚSTRIA, VIAÇÃO E OBRAS PÚBLICAS. Relatório apresentado ao Presidente da Republica dos Estados Unidos do Brazil pelo Ministro de Estado dos Negocios da Industria, Viação e Obras Publicas, Joaquim Murtinho, Em Maio de 1897. Rio de Janeiro: Imp. Nacional, 1897.

BRASIL. MINISTÉRIO DA AGRICULTURA. Theses sobre colonização do Brasil, Projeto de solução ás questões sociaes, que se prendem a este difícil problema, Relatório apresentado ao Ministério da Agricultura, Commercio e Obras Públicas em 1873 pelo Conselheiro João Carlos de Menezes e Souza. Rio de Janeiro: typ. Nacional, 1875.

\section{Documentos Cartoriais}

$1^{\circ}$ REGISTRO DE IMÓVEIS DA CAPITAL. SOCIEDADE INCORPORADORA. “Ata da Primeira Assemblea Geral da 'Sociedade Incorporadora', em 21 de dezembro de 1907, para elevação do capital de cinqüenta a quinhentos contos de réis". "Ata da Assemblea Geral Extraordinaria da em 12 de dezembro de 1908".

"Ata da Assemblea Constituinte Sociedade Incorporadora em 25 de agosto de 1906".

"Estatutos da Sociedade Incorporadora".

"Relatorio da Directoria da Sociedade Incorporadora para justificar o $4^{\circ}$ augmento de capital perante a assemblea geral extraordinária a realizar-se no dia 11 de dezembro de 1911".

"Ata da Assemblea Geral Extraordinariada da Sociedade Incorporadora realizada a 30 de dezembro de 1911".

"Ata da Assemblea Geral Extraordinariada da Sociedade Incorporadora realizada a 30 de dezembro de 1912".

"Ata da Assemblea Geral Ordinária da Sociedade Incorporadora em 23 de junho de 1909 para aprovação do relatório de contas do ano de 1908 e eleição de um diretor". 
BANCO DE CREDITO REAL DE SÃO PAULO. Relatorio que será apresentado á Assembléa dos accionistas convocada para 7 de maio de 1902. São Paulo: Duprat \& Comp., 1902.

PERNAMBUCO. CONGRESSO LEGISLATIVO. Relatório apresentado ao Congresso de Pernambuco em 1898, pelo então senador dr. Joaquim Tavares de Mello Barretto, na qualidade de membro da commissão de inquerito sobre a 'crise da lavoura'. Recife: Imprensa Industrial, 1909.

SOCIEDADE PAULISTA D'AGRICULTURA, COMMERCIO E INDUSTRIA. Acta da Assembléa Geral Realisada no dia 15 de julho de 1902 contendo parecer da commissão nomeada para estudar a questão relativa a limitação da plantação cafeeira e o trabalho do dr. Carlos Botelho sobre o mesmo assumpto e sobre colonisação. São Paulo: Duprat, 1902.

Relatório relativo ao anno de 1905, apresentado pela Diretoria á Assembléa Geral Ordinaria em 13 de março de 1906. São Paulo: Espindola, 1906.

IEB. FUNDO CAIO PRADO JUNIOR, Fazenda Guatapará [várias caixas]

\section{REFERÊNCIAS BIBLIOGRÁFICAS}

ALBUQUERQUE, Diogo Velho C. de. Regimen Hypothecario Brazileiro (Legislação e Doutrina). Porto Alegre: Livraria Americana, 1918.

ALMICO, Rita de C. Fortunas em movimento: um estudo sobre as transformações na riqueza pessoal em Juiz de Fora / 1870-1914. Campinas: Unicamp (Dissertação de Mestrado), 2001.

Dívida e obrigação: as relações de crédito em Minas Gerais, séculos XIX/XX. Niterói: UFF (Tese de Doutorado), 2009.

ARAUJO FILHO, José Ribeiro de. "O café, riqueza paulista". São Paulo: Boletim Paulista de Geografia. v. 01, n. 23, p. 78-114, 1956.

Santos, o Porto do Café. Rio de Janeiro: IBGE, 1969.

ARRUDA, João. A letra de cambio actual. São Paulo: Siqueira, Nagel \& Comp., 1913.

ANDERSON, Perry. Considerações sobre o marxismo ocidental. São Paulo: Boitempo, 2004.

BARBOSA, Alexandre de F. A Formação do Mercado de Trabalho no Brasil. São Paulo: Alameda, 2008.

BARBOSA, Ruy. Obras completas de Rui Barbosa (V. XVIII Tomo II, Relatório do ministro da Fazenda). Rio de Janeiro: Ministério de Educação e Saúde, 1949.

BARROS, Jacintto. Credito agropecuario. São Paulo: Salesiano, 1917.

BARROZO. J. Liberato. A letra de cambio segundo o direito pátrio, doutrina do titulo XVI do Codigo Commercial. Rio de Janeiro: Garnier, 1868.

BEIGUELMAN, Paula, A formação do povo no complexo cafeeiro: aspectos políticos, São Paulo: EDUSP, 2005.

BESKOW, Paulo Roberto. O Crédito Rural Público numa Economia em Transformação: Estudo Histórico e Avaliação Econômica das Atividades de Financiamento Agropecuário da CREAI/BB, de 1937 a 1965. Campinas: Unicamp (Tese de doutorado), 1994.

BORGES, José Ferreira. Diccionario Juridico-Commercial. Porto: Typ. de Sebastião José Pereira, 1856 ( $2^{\mathrm{a}}$ ed.). 
BRAGONI, Beatriz. "Mercados, monedas y crédito a la luz del funcionamiento de una entidad bancaria (Mendoza, 1866-1879)". Desarollo Económico. V. 45, n. 177 abr. jun. 2005.

BRASIL, IBGE. 500 anos de povoamento. Rio de Janeiro: IBGE, 2007.

BOTERO RESTREPO, María Mercedes. "Instituiciones bancarias en Antioquia, 18721886". Lecturas de Economia, n. 17, maio-agosto de 1885, p. 43-147.

"Moneda y banca en una economía aurífera. La región de Antioquia (Colombia), 1850-1890”. América Latina en la Historia Económica, n. 35, p. 53-81, 2011.

BOXER, Charles. R. O império colonial português. São Paulo: Edições 70, 1977.

CAMARGO, José Francisco. Crescimento da população do Estado de São Paulo e seus aspectos economicos. São Paulo: 1981.

CANABRAVA, Alice Piffer. Uma economia de decadência: os níveis de riqueza na capitania de São Paulo, 1765-67. Revista Brasileira de Economia, 1972, v. 26, n. 4, pp. 95-124.

CANO, Wilson. Raízes da Concentração Industrial de S. Paulo. São Paulo: Queiroz, 1981.

"Padrões Diferenciados das Principais Regiões Cafeeiras (1850-1930)". Estudos Econômicos, vol. 15, $\mathrm{n}^{\mathrm{o}}$ 2, maio/agosto de 1985.

CAPALBO, Clovis Roberto. A história de Jaboticabal. 1828-1978. Jaboticabal: s/e, 1978.

CARDOSO, Fernando Henrique. "Condições Sociais da Industrialização: o caso de São Paulo". São Paulo: Revista Brasiliense, n. 28, Mar/Abr. 1960.

"O Café e a Industrialização da Cidade de São Paulo". São Paulo: Revista de História, n. 42, p. 471-475, 1960.

CARONE, E. A República velha. Instituições e classes sociais. São Paulo: Difel, 1972. A República velha. Evolução Política. São Paulo: Difel, 1974.

CARVALHO. Solução da Crise do Café. São Paulo: Livraria Civilisação, 1901.

CASALECCHI, José Ênio. O Partido Republicano Paulista (1889-1926). São PauloSP: Editora Brasiliense, 1987.

CASTRO, Hebe Maria Mattos. Ao sul da história: lavradores pobres na crise do trabalho escravo. São Paulo: Brasiliense, 1987.

CERUTTI, Mario. "Comerciantes y generalización del crédito laico en México (18601910). Experiencias regionales". Anuario del IEHS, n. 7, p. 211-235, 1992.

CORAZZA, Gentil, "Sistema financeiro (e desenvolvimento) do Rio Grande do Sul", Ensaios FEE. Porto Alegre, v. 23, Número Especial, p. 491-516, 2002.

CORREA, Fábio R. C. "Os Bancos de Custeio Rural e o crédito agrícola em São Paulo (1906-1914)". História Econômica \& História de Empresas, v. 15, n. 2, p. 143-165, 2012.

"Associativismo de crédito entre os fazendeiros paulista, 1890-1914". Tercer Congreso Latinoamericano de Historia Económica y XXIII Jornadas Argentinas de Historia Económica. San Carlos de Bariloche (Argentina), agosto de 2012.

CORREA, Fábio R. C. \& GOMEZ, Juan Lucas. "Un acercamiento al financiamiento hipotecario en Argentina y Brasil durante la primera mitad del siglo XX: las experiencias de F.I.N.C.A y la Associação Predial de Santos". $7^{\circ}$ Congresso do Conselho Europeu de Investigações Sociais sobre a América Latina (CEISAL). Universidade Fernando Pessoa, Braga (Portugal), junho de 2013.

COSTA. Emilia Viotti da. Da senzala a colônia. São Paulo: Liv. Ciências Humanas, 1982.

COSTA, Fernando Nogueira da. Os Bancos de Minas Gerais (1889-1920). Campinas: Unicamp (Dissertação de Mestrado), 1978. 
Brasil dos Bancos. São Paulo: EDUSP, 2012.

COSTA, Wille Duarte. Títulos de crédito. Belo Horizonte: Del Rey, 2005.

COUTY, Louis. Etude de biologie industrielle sur le caffe, imprime du messager du Bresil. Rio de Janeiro, s/n., 1883.

CLUB DA LAVOURA DE SÃO CARLOS. Estatistica agrícola do município de São Carlos do Pinhal. São Paulo: Typ. Panperio\& Comp., 1899.

CROCE. Crises financeiras na primeira década republicana e os bancos em Minas Gerais (1889 - 1903). Belo Horizonte: (Tese de doutorado, CEDEPLAR/UFMG), 2013.

DE PAULA, João Antônio. "Raízes do desenvolvimentismo: pensamento e ação de João Pinheiro". Pesquisa \& Debate. Revista do Programa de Estudos Pós-Graduados em Economia Política, v. 15, n. 2 (26), 2004.

DEAECTO, Marisa M. Comércio e vida urbana na cidade de São Paulo. São Paulo: Senac, 2002.

DEAN, Warren. A Industrialização de São Paulo (1800-1945). São Paulo: Difel, 1971. "A pequena propriedade dentro do complexo cafeeiro: sitiantes no município de Rio Claro, 1870-1920". Revista de História, n. 106, v. LIII, 1976, p. 487-501. Rio Claro: um sistema brasileiro de grande lavoura, 1820-1920. Rio de Janeiro: Paz e Terra, 1977.

DEBES, Célio. Washington Luís: 1869/1924. São Paulo: Imprensa Oficial, 1994.

DELFIM NETTO, Antonio. O problema do café no Brasil. São Paulo: IPE/USP, 1981.

DEPARTAMENTO NACIONAL DO CAFÉ. O Café no Segundo Centenário de Sua Introdução no Brasil. Rio de Janeiro: INC, 1934.

DENIS, Pierre. Bresil au XX siecle. Paris: ArmandColin 1910.

DIAZ, Ana Isabel Grijalva. "La reestructuración de la banca y el crédito agrícola en Sonora después de la Revolución, 1918-1934". Segundo Congreso Latinoamericano de Historia Económica e Cuarto Congreso Internacional de la Asociación Mexicana de Historia Económica. Cidade do México, 2010.

DUARTE, A. Teixeira. Catecismo da Cooperação: O cooperativismo em Minas Gerais (1908-1911)-Seu histórico, suas practicas, seus resultados, Belo Horizonte: Beltrão \& Comp., 1912.

EGYDIO DE CARVALHO, Paulo. Ensaio sobre algumas questões de direito e economia politica. São Paulo: J. G. d'Arruda Leite, 1896.

ELLIS JR, Alfredo. A Evolução da Economia Paulista e Suas Causas. Rio de Janeiro: Cia Ed. Nacional, 1937. O café e a Paulistânea. São Paulo: Edusp, 1951.

FALEIROS, Rogério Naques. Homens do café: Franca 1880-1920. Ribeirão Preto: Holoes, 2002.

Fronteiras do Café: Fazendeiros e Colonos no Interior Paulista (1917-1937). Bauru: Edusc, 2010.

FAUSTO, Boris. "Expansão do Café e Política Cafeeira". Boris FAUSTO (org.) História Geral da Civilização Brasileira. Tomo III: "O Brasil Republicano". São Paulo: Difel, 1985.

"Estado e burguesia agroexportadora na Primeira República: uma revisão historiográfica". Novos Estudos Cebrap, v. 27, 1990.

FERNANDES, Symphoroso Lara. Syndicatos agricolas: notas à lei $n$. 979, de 6 de janeiro de 1903. São Paulo: Rothschild, 1906.

FERREIRA, Marieta de Moraes. A crise dos comissários de café do Rio de Janeiro. Niterói: UFF (Dissertação de Mestrado), 1977. 
FIGUEIREDO, A. de Souza. Credito e os bancos. Rio de Janeiro: Garnier, 1865.

FONTANARI, Rodrigo. O Problema do Financiamento: Uma Análise Histórica Sobre o Crédito no Complexo Cafeeiro Paulista. Casa Branca (1874-1914). Franca: Unesp (Dissertação de Mestrado), 2010.

FRAGOSO, João L. Ribeiro. Homens de grossa aventura: acumulação e hierarquia na praça mercantil do Rio de Janeiro (1790-1830). Arquivo Nacional: 1992.

FRANCO, Bernardo de Souza. Os bancos do Brasil. Brasília: UNB, 1984.

FRANCO, Gustavo H. B. Reforma Monetária e Instabilidade Durante a Transição Republicana. Rio de Janeiro: BNDES, 1983.

A década republicana: o Brasil e a economia internacional - 1888/1900. Rio de Janeiro: IPEA, 1991.

FRANCO, Maria S. de Carvalho. Homens livres na ordem escravocrata. São Paulo: Ática, 1974.

FREITAS FILHO, Almir Pita e MARTINS, Margareth G. "Maria Bárbara Levy: Historiadora de Empresas no Brasil". Revista Economia Contemporânea. v. 6, n. 2, jul./dez. 2002.

FRITSCH, Winston. “Aspectos da Política Econômica do Brasil, 1906-1914”. In: Paulo NEUHAUS (coord.). Economia Brasileira: uma visão histórica. Rio de Janeiro: Campus, 1980.

"Sobre as Interpretações Tradicionais da Lógica Política da Política Econômica da Primeira República" Revista de Estudos Econômicos, v. 15, nº 2, 1985.

FUNDAÇÃO JOÃO PINHEIRO, "Congresso agrícola, comercial e industrial de Minas Gerais, em 1903”. Análise e Conjuntura, Belo Horizonte, v. 11, n. 5, p. 122-220, 1981.

FURTADO, Celso. Formação Econômica do Brasil. São Paulo: Cia. Ed. Nacional, 2000.

GAMBI, Thiago Fontenlas Rosado. O banco da ordem: política e finanças no império brasileiro (1853-66), Campinas: UNICAMP (Tese de Doutorado), 2010.

"Projetos políticos e crises econômicas: análise do caso do Banco do Brasil na crise bancária de 1864". IV Conferência Internacional de História Econômica \& VI Encontro de Pós-Graduação em História Econômica. Associação Brasileira de História Econômica (ABPHE). São Paulo, out. de 2012.

GARCIA, Graciela Bonassa, "Registros paroquiais de terras". In: Marcia M. MOTTA e Elione GUIMARAES. Propriedades e disputas: fontes para a história do oitocentos. Niterói: Eduff, 2011, p. 65-70.

GARCIA LOPEZ, Jose Ramon. "El sistema bancário español del siglo XIX: Una estructura dual? Nuevos planteamientos y nuevas propuestas". Revista de Historia Económica. Madri, v. VII, n. 1, 1989.

GOMES, Amanda Muzzi. "Monarquistas restauradores e jacobinos: ativismo político". Revista Estudos Históricos. v. 21, n. 42, p. 284-302, 2009.

GORENDER, Jacob. O escravismo colonial. São Paulo: Ática, 1978.

POULAT, Emile. "Les origines du crédit agricole: (1840-1914) (resenha da tese de André Gueslin)". Archives des sciences sociales des religions, v. 48, n. 2, p. 292-3, 1978.

GUESLIN, André. "Crédit agricole et agriculture en France au XX esiècle". Économie rurale, v. 184, n. 1, p. 107-115, 1988.

"Les banques de l'économiesocialeen France: perspectives historiques". Revue d'économiefinancière, v. 67, n. 3, p. 21-43, 2002.

GUIMARAES, A. "O Comissário de Café como Banqueiro do Fazendeiro no Interior". In: O Café no Segundo Centenário de Sua Introdução no Brasil. Rio de Janeiro: Dep. Nacional do Café, 1934. 
GUIMARAES, Carlos Gabriel. "O Império e os bancos comerciais do Rio de Janeiro na segunda metade do século XIX. Os casos do Banco Mauá, MacGregor\& Cia., do Banco Rural e Hipotecário do Rio de Janeiro e do Banco Comercial e Agrícola". Anais do III Congresso Brasileiro de História Econômica e da $4^{a}$ Conferência Internacional de História de Empresas. Curitiba: ABPHE/UFPR, 1999.

"O Banco Rural e Hipotecário do Rio de Janeiro e o Pós-Guerra do Paraguai, 1871-1875". V Congresso Brasileiro de História Econômica e $\sigma^{a}$ Conferência Internacional de História de Empresas ABPHE. Caxambu, 2003.

"A Guerra do Paraguai e a atividade bancária no Rio de Janeiro no período 18651870: o caso Banco Rural e Hipotecário do Rio de Janeiro." Universidade Federal Fluminense, 2007.

A presença inglesa nas finanças e no comércio do Brasil imperial: os casos da Sociedade Bancária Mauá, McGregor \& Cia (1854-1866) e da firma inglesa Samuel Phillips \& Cia (1808-1840). São Paulo: Alameda, 2012.

"O império e o crédito hipotecário: o estudo de caso do Banco Commercial e Agricola 1858-1861". I Seminário Interno do Programa de Pós-Graduação em Desenvolvimento Socioeconômico. UFMA, 3 a 4 de junho de 2013.

GRANZIERA, Rui. Moeda e Credito no Limiar do Capitalismo no Brasil: (a outra história financeira). Campinas: IE-UNICAMP (Tese de Doutorado), 1976.

A Guerra do Paraguai e o capitalismo no Brasil. São Paulo: Hucitec, 1979.

GRAHAN, Richard. Grã-Bretanha e o início da modernização no Brasil. São Paulo: Brasiliense, 1973.

GODOY, José H. Artigas de. Coronelismo em Ribeirão Preto de 1889 a 1937. São Paulo: FFLCH/USP (Dissertação de mestrado em Ciência Política), 2000.

HANLEY, Anne G. e MARCONDES, Renato Leite. "Bancos na transição republicana em São Paulo: o financiamento hipotecário (1888-1901)". Est. econ., São Paulo, v. 40, n. 1, p. ,103-131 JANEIRO-MARÇO 2010.

HAUTCEEUR, Pierre-Cyrille; GALLAIS-HAMONNO, Georges. Le marché financier français au XIXe siècle: Récit. Publications de la Sorbonne, 2007.

HILFERDING, Rudolf. O Capital Financeiro. São Paulo: Nova Cultural, 1985.

HOBSBAWM, Eric J. A era dos impérios.

HOLLOWAY, Thomas H. "Condições do mercado de trabalho e organização do trabalho nas plantações na economia cafeeira de São Paulo, 1885-1915”. Estudos econômicos, São Paulo, v. 2, n. 6, p. 145-205, dez. 1972.

Vida e Morte do Convenio de Taubaté. Rio de Janeiro: Paz e Terra, 1978.

Imigrantes para o café. Rio de Janeiro: Paz e Terra, 1984.

JANOTTI, Maria de L. Mônaco. Os subversivos da República. São Paulo: Brasiliense, 1986.

JORDAO, Carlos. “A Ação dos comissários de café” in: O Café no segundo centenário de sua introdução no Brasil. Rio de Janeiro: Dep. Nacional do Café, 1934.

KAUTSKY, Karl. A Questão Agrária. São Paulo: Nova Cultural, 1986.

KAREPOVS, Dainis (Coord.). Prudente de Moraes, Parlamentar da Província de São Paulo (1868-1889). São Paulo: ALESP, 2004.

KOCKA, Jürgen; MARTİNEZ, Marina Sanchis. "Los artesanos, los trabajadores y el Estado: hacia una historia social de los comienzos del movimiento obrero alemán". Historia Social, n. 12, p. 101-118, 1992.

KUGELMAS, Eduardo. "Políticas Públicas na Administração Paulista". Cadernos Fundap. São Paulo, v. 9, p. 41-67, 1985.

A Difícil Hegemonia: Um Estudo Sobre São Paulo na Primeira República. São Paulo: FFLCH-USP (tese do doutorado), 1987. 
"Estado e Federação na República Velha”. Revista São Paulo em Perspectiva. São Paulo, v. 2, n.4, p. 8-10, 1988.

"Moeda, Café e Poder na Primeira República". In: Anuário Ciências Sociais Hoje. São Paulo, Vértice/Ed. Revista dos Tribunais/ANPOCS, 1988.

KUNIOCHI, Marcia Naomi. Crédito, negócios e acumulação: Rio de Janeiro, 18441857. Diss. 2001.

"Crédito, Especulação e Acumulação nos Negócios Mercantis, Rio de Janeiro: 1842-1857". História e Economia: revista interdisciplinar (BBS), v. 4, n. 2, 2008 pp. 199-220.

FRANCO, A. de Lacerda. Estudos Sobre a Aplicação da Mutualidade ao Credito Rural e Agrícola no Brasil. São Paulo: Ed. Spindola, 1900

FRAGOSO, João L. Ribeiro. Homens de grossa aventura: acumulação e hierarquia na praça mercantil do Rio de Janeiro (1790-1830). Arquivo Nacional: 1992.

Sistemas agrários em Paraíba do Sul (1850-1920): um estudo de relações não capitalistas de produção. Rio de Janeiro: UFF (Dissertação de Mestrado), 1983

LACOMBE, Americo Jacobina. "A igreja no início do século XX". In: Luiz Antonio Severo da Costa. Brasil: 1900-1910. Rio de Janeiro: Biblioteca Nacional, 1980, p. 47-60.

LACERDA, Joaquim Franco. Producção e Consumo de Cafe no Mundo. Situação Economica e Financeira do Brazil. Questoes Economicas e Sociaes. São Paulo: Typ. Ind. de São Paulo, 1897.

LAÈRNE, C F van Delden. Le Brésil et Java rapport sur la culture du café en Amerique, Asie et Afrique. Paris: Challamel, 1885.

LALIÈRE. A. Le Café dans l'Etat de Saint Paul (Bresil). Paris: Challamel, 1909.

LAMOUNIER, M. L. Da escravidão ao trabalho livre: a lei de locação de serviços de 1879. Campinas: Papirus, 1988.

"Agricultura e mercado de trabalho: trabalhadores brasileiros livres nas fazendas de café e na construção de ferrovias em São Paulo, 1850-1890". Estudos Econômicos. 37 (2), abril-junho 2007, p. 353-372.

LANNA, Ana Lúcia. A transformação do trabalho: a passagem para o trabalho livre na zona da Mata Mineira, 1870-1920. Campinas: Ed. Da Unicamp, 1988.

LAUNAY, Marcel. "Le clergé et la naissance des caisses rurales en Bretagne (18931914)". In: Annales de Bretagne et despays de l'Ouest. Presses Universitaires de Rennes, 1987. p. 553-564.

LEAL, Victor Nunes. Coronelismo Enxada e Voto $(\mathrm{O}$ município e o Regime Representativo no Brasil). São Paulo: Companhia das Letras, 2012.

LEVI, Darrell E. A família Prado. São Paulo: Cultura, 1977.

LEVY, Maria Barbara. História da bolsa de valores do Rio de Janeiro. Rio de Janeiro: Ibmec, 1977. Ibmec, 1977.

A indústria do Rio de Janeiro através de suas sociedades anônimas: esboços de história empresarial. Rio de Janeiro: Editora UFRJ, 1994.

O encilhamento. Economia brasileira: uma visão histórica. Rio de Janeiro: Campus, p. 191, 1980.

LEVY, María Barbara; ANDRADE, Ana Maria de. "Fundamentos do sistema bancário no Brasil: 1834-1860". Estudos Econômicos, v. 15, p. 17-48, 1985.

LINK, Arthur S. História moderna dos Estados Unidos. Rio de Janeiro: Zahar, 1965.

LLOYD, Reginald. Impressões do Brazil no século vinte. Londres: Lloyd's Greater Britain, 1913. 
LLUCH, Andrea. "Comercio y comerciantes rurales. Un estudio de los perfiles y prácticas crediticias de los comerciantes de campaña, 1885-1930". Red de Estudios Rurales (RER). Programa de Estudios Rurales, 2004.

Repensando a los comercios rurales de la pampa argentina: 1900-1930. Anuario del Centro de Estudios Históricos" Prof. Carlos SA Segreti", v. 2, n. 2, p. 135-160, 2002.

LOBO, Maria Eulália Lahmeyer. "O encilhamento". Revista Brasileira de Mercado de Capitais, v. 2, n. 5, p. 261-301, 1976.

História do Rio de Janeiro: Do Capital Comercial ao Capital Industrial e Financeiro. Rio de Janeiro: IBMEC, 1978.

LOVE, J. São Paulo na Federação Brasileira: 1889-1937: A Locomotiva. Rio de Janeiro: Paz e Terra, 1982.

MAGALHÃES, Wanda Moreira. Eleitores e eleitosos agentes do poder em Campinas, na segunda metade do século XIX. São Paulo 1992.

MARCONDES, Renato Leite. A Arte de Acumular na Economia Cafeeira: Vale do Paraíba Século XIX. Lorena: Stiliano, 1998.

"O financiamento hipotecário da cafeicultura do Vale do Paraíba Paulista (1865-1887)". Revista Brasielira de Economia, v. 56, n. 1, p. 147-170, JAN-MAR, 2002.

MARICHAL, Carlos. "Historiografia de la Banca Latinoamericana". América Latina en la historia económica. Boletín de fuentes, v. 2, n. 03, p. 73-90, Ene-Jun, 1995.

MARQUES, Teresa C. N. "Bancos e desenvolvimento econômico: uma revisão das teses de Gerschenkron à luz da Cervejaria Brahma, 1888-1917”. História e Economia. 1 (1), 2005.

MÁRQUEZ, José Ignacio Díez. "El Banco Nacional, 1880-1904: el fracaso de la moneda legal”. Lecturas de Economía [Medellín], n. 28, p. 29-76, 1989.

MARTINEZ-SOTO, Ángel Pascual. "Los orígenes del cooperativismo de crédito agrario en España". CIRIEC-ESPAÑA, n. 44, p. 57-104, 2003.

e RODRÍGUEZ, Susana Martínez. "Cooperativismo Agrario de Credito en Espana (1890-1935); Solidaridad Desde Abajo?" Segundo Congreso Latinoamericano de Historia Económica e Cuarto Congreso Internacional de la Asociación Mexicana de Historia Económica. Cidade do México, 2010.

MARTINS, Ana Luiza, Revistas em Revista: Imprensa e Práticas Culturais em Tempos de República, São Paulo (1890-1922). São Paulo: Edusp, 2001

MARTINS, José de Souza. O Cativeiro da Terra. São Paulo: LECH, 1981

MEIRA, Roberta Barros. Banguês, engenhos centrais e usinas: o desenvolvimento da economia açucareira em São Paulo e a sua correlação com as políticas estatais (1875-1941). São Paulo: Alameda, 2010.

"Os louvores ao açúcar nas terras do café: o crescimento da produção açucareira paulista e fluminenses entre 1875-1889", Revista Territórios \& Fronteiras, v. 2, n. 1, p. 6-26, 2011.

MELLO, João Manoel C. de. O Capitalismo Tardio. Rio de Janeiro: Brasiliense, 1987.

MELLO, Pedro Carvalho de. "Os Fazendeiros de Café e o mercado financeiro e de Capitais, 1871/88”. Estudos Econômicos, v. 14, n. 1, p.145-161, 1984.

MENDONÇA, Sonia R. de. O ruralismo brasileiro: 1888-1931. São Paulo: Hucitec, 1997.

"A Sociedade Nacional de Agricultura e a institucionalização de interesses agrários no Brasil", Revista do Mestrado em História. (Universidade Severino Sombra), V. 2, 1999. 
A política de cooperativização agrícola do estado brasileiro (1910-1945). Niterói: EDUFF, 2002.

MENDRAS, Henri. "Les organisations agricoles et la politique". Revue Française de Science Politique, v. 5, n. 4, p. 736-760, 1955.

MENZ, M. M. "O Crédito e a Economia Colonial: século XVIII". In: CARRARA, Angelo Alves. (org.). A Vista ou a Prazo: comércio e crédito nas Minas Setencistas. Juiz de Fora, Ed. UFJF, 2010.

MILLIET, Sérgio. Roteiro do café e outros ensaios. São Paulo: Editora Sergio Milliet, 1939.

MOGLIA, Leandro. "La intervención del Estado en el proceso de formación del Cooperativismo agrícola chaqueño y sus posteriores relaciones (1918-1960)". Segundo Congreso Latinoamericano de Historia Económica e Cuarto Congreso Internacional de la Asociación Mexicana de Historia Económica. Cidade do México, 2010.

MOMBEIG, Pierre. Pioneiros e Fazendeiros de São Paulo. São Paulo: Hucitec, 1998

MELLO, Zélia M. Cardoso de. "Contribuição ao estudo da formação do empresariado paulista". Revista Brasileira de História, v 2, n. 4, p. 193-216, Set. 1982

Metamorfose da Riqueza, São Paulo, 1845-1895. São Paulo: Hucitec, 1985

MELLO, Pedro Carvalho de. "Os fazendeiros de café e o mercado financeiro e de capitais, 1871/88”. Estudos Econômicos, v. 14, n. 1, p.145-161, 1984

MORAES, Maria Luiza Paiva Melo. Companhia Agrícola Francisco Schmidt: origem, formação e desintegração (1890-1924). São Paulo: FFLCH (Dissertação de Mestrado), 1980.

Atuação da firma Theodor Wille \& Cia. no mercado cafeeiro do Brasil, 18441918. São Paulo: FFLCH (Tese de Doutorado), 1988.

MOTTA, Márcia Maria Menendes. Nas fronteiras do poder, conflito e direito a terra no Brasil do século XIX. Rio de Janeiro: Vício de Leitura, 1998.

MOURA, Valdiki. Bibliografia brasileira do cooperativismo: pequeno ensaio de sistematização. Rio de Janeiro: Casa do Estudante do Brasil, 1951.

NABUCO, Joaquim. Um estadista do Império, Nabuco de Araujo, sua vida, suas opiniões, sua época, por seu filho Joaquim Nabuco. Rio de Janeiro: Garnier, 1897.

NICOLAS, Philippe. "Emergence, développement et rôle des coopératives agricoles en France. Aperçus sur une histoire séculaire", Économie rurale, v. 184, n. 1, p. 116$122,1988$.

NORONHA, Andrius E. Beneméritos empresários: história social de uma elite de origem imigrante do sul do Brasil (Santa Cruz do Sul, 1905-1966). Porto Alegre: PUC-RS (Tese de doutorado), 2012.

NOZOE, Nelson Hideiki. São Paulo: economia cafeeira e urbanização. São Paulo: IPE/USP, 1984.

OBERACKER JUNIOR, Carlos H. "Vestígios suíços na história do Brasil". Revista de História, São Paulo, v. XXXV, n. 72, p. 463-482, 1967.

OLIVEIRA, Maria Luiza Ferreira de Oliveira. Entre a Casa e o Armazém: Relações Sociais e Experiência da Urbanização em São Paulo, 1850-1900. São Paulo: Alameda, 2005.

OLIVEIRA, Marcos Fabio Martins de. O pensamento econômico de Francisco Salles, João Pinheiro e João Luís Alves e o desenvolvimento de Minas Gerais (1889-1914). São Paulo: FFLCH/USP (Tese de doutorado), 2012.

OÑATE, Abdiel. "El credit foncier mexican ó las vicitudes de un banco de crédito territorial francês em México: la banca anterior al cooperativismo revolucionário, 1900-1929”. Segundo Congreso Latinoamericano de Historia Económica e Cuarto 
Congreso Internacional de la Asociación Mexicana de Historia Económica. Cidade do México, 2010.

OURO PRETO, Affonso Celso de Assis Figueiredo, Visconde de. Credito movel pelo penhor e o bilhete de mercadorias. Rio de Janeiro: Laemmert, 1898.

"Finanças", In: A década republicana. Rio de Janeiro: Cia. Typ. Do Brasil, 1899, vol. I.

PAZ FONTENLA, Vicente. Bancos (teoría e realidade). Rio de Janeiro: Atlas, 1944. História dos bancos no Brasil. Rio de Janeiro: s/n., 1975.

PELAĖZ, Carlos Manuel e SUZIGAN, Wilson. História Monetária do Brasil: Análise da Política, Comportamento e Instituições Monetárias. Brasilia: Ed. UnB, 1981.

PEREIRA, Maria Apparecida Franco. Comissário de café no porto de Santos: 1870-1920. São Paulo, 1980.

PEREIRA, Robson Mendonça. O municipalismo de Washington Luís em sua atuação em Batatais (1893-1900): aspectos da modernização urbana do interior paulista na República Velha. Franca: UNESP-FHDSS (Dissertação de Mestrado), 1998.

PERISSINOTO, Renato M. Classes dominantes e hegemonia na república velha. Campinas: Ed. Unicamp, 1994.

"Classe dominate e política econômica na economia cafeeira (1906 - 1930)." Perspectivas, 1993: 165-189.

"Classes dominantes, Estado e os conflitos políticos na Primeira República em São Paulo: Sugestões para pensar a década de 1920." In A década de 1920 e as origens do Brasil moderno. LORENZO H. C. e COSTA, W. P. 1997. São Paulo: Unesp.

Estado e Capital Cafeeiro em São Paulo (1889-1930). São Paulo: Fapesp, 1999.

PETRONE. M. T. S. O Barão de Iguape. São Paulo: Cia Ed. Nacional, 1976.

PIÑERO, Théo Lobarinhas. "A Carteira Hipotecária do Banco do Brasil: os conflitos em torno do Crédito Agrícola no II Reinado". In GUIMARAES, Elione S. e MOTTA, Márcia M. de M. (orgs.). Campos em disputa: história agrária e companhia. São Paulo, Annablume pp. 41-62, 2007.

PINHEIRO, Marcos Antonio Henriques. Cooperativas de crédito história da evolução normativa no Brasil. Brasília: Banco Central do Brasil, 2008

PINHO, Diva Benevides (Org.). A problemática do cooperativismo no desenvolvimento econômico. São Paulo: Fund. Friederich Naumann, 1973.

Dicionário de cooperativismo. São Paulo: FFLCH, 1962.

Sindicalismo e cooperativismo - evolução doutrinária e problemas atuais. São Paulo: Instituto Cultural do Trabalho, 1966.

PINTO, Liliane Faria Corrêa. As políticas públicas de incentivo ao cooperativismo em Minas Gerais, 1903-1922. São Paulo, 2005.

PIRES, Anderson. Café, finanças e bancos: uma análise do sistema financeiro da zona da Mata de Minas Gerais: 1889/1930. Juiz de Fora/São Paulo: FFLCH-USP, 2004

e Rita de C. ALMICO. "Crédito e finanças em uma sociedade cafeeira". São Paulo: História e Economia: Revista Interdisciplinar (BBS), v. 4, n. 2, 2008, pp. 221244.

PRADO Jr, C. História econômica do Brasil. São Paulo: Brasiliense, 1945.

POULAT, Emile. "Gueslin (André) Les Origines du Crédit Agricole (1840-1914)". Archives des sciences sociales des religions, v. 48, n. 2, p. 292-293, 1979.

QUEIROZ, Joaquim Silverio da Fonseca. Informações uteis sobrea a cafeicultura. São Paulo, 1914. 
RAMOS, João Eremita da Silva Ramos. Indice alphabetico das leis e decretos do estado de São Paulo, 1889-1921. São Paulo: Saraiva, 1922.

RIBEIRO, Maria A. R. "Padrão de acumulação dos fazendeiros do Oeste, 1850-1901: primeiras notas de três estudos de caso - um Comendador, um Marques e um conde". Hermes \& Clio: Grupo de estudos e pesquisa em história econômica FEA/USP Seminários de História Econômica, $1^{\circ}$ de setembro de 2010 (texto para discussão).

RIGUZZI, Paolo. "Sistema financiero, banca privada y crédito agrícola en México, 18971913: ? Un desencuentro anunciado?". Estudios Mexicanos, v. 21, n. 2, 2005, pp. 333-367.

RODRIGUES, Pedro Parga, "A Lei Hipotecária de 1864 e a propriedade no XIX". In: Anais do XIII Encontro de História ANPUH. Rio de Janeiro: UFRRJ, 2008.

"Augusto Teixeira de Freitas e o Registro Geral de Imóveis no Império". Anais do XXV Simpósio Nacional de História, ANPUH, Fortaleza, 2009.

ROCHA, Alfredo. Caixas economicas e o credito agrícola. Rio de Janeiro: Imprensa Nacional, 1905.

SALLES, Campos. Discursos: na propaganda. Rio de Janeiro: Imp. Nacional, 1902.

SALLUM JR, Basílio. Capitalismo e cafeicultura. São Paulo: Duas cidade, 1982.

SAES, Alexandre Macchione. Conflitos do Capital - Light Versus Cbee na Formação do Capitalismo Brasileiro (1988-1927). Bauru: Edusc, 2010.

SAES, Flávio A. M. de. "Estado e sociedade na Primeira República: a questão monetária e cambial durante a crise cafeeira (1896-1906)". Revista Brasileira de História, v. 1, n. 2, 1981.

"A questão do crédito na economia paulista da primeira república". SAES et alli. História Econômica: ensaios. São Paulo: IPE-USP, 1983 pp. 121-152

Crédito e bancos no desenvolvimento da economia paulista 1850 - 1930. São Paulo: IPE/USP, 1986.

A grande empresa de serviços públicos na economia cafeeira. São Paulo: Hucitec, 1986.

"Credito e desenvolvimento em economias agroexportadoras: o caso de São Paulo (1850-1930).In: Revista do Instituto de Estudos Brasileiros. São Paulo: IEB, 1988, n. 29, pp. 29-48.

"Fontes para a história dos bancos no Brasil (o caso de São Paulo: 1850-1930)". América Latina en la Historia Económica, v. 2, n. 03, p. pp. 63-71, 1995.

SCHALLENBERGER, Erneldo. "Cooperativismo e desenvolvimento comunitário". Mediações-Revista de Ciências Sociais, v. 8, n. 2, p. 9-26, 2003.

SANTOS, Lucio José dos. Ao povo mineiro: as caixas agrarias do systema Raiffeisen. Rio de Janeiro: A Patria Brasileira, 1911.

SANTOS, Pedro Joaquim dos. Penhor mercantil, Sua Prova, direitos e accoes resultantes deste contracto: como se distingue do penhor civil e agricola. Salvador: Wilcke Picard, 1898.

SECCO, L. . "Cooperativas e Conselhos Operários". Lutas Sociais (PUCSP), São Paulo, v. 9/10, p. 169-178, 2003.

SIMONSEN, Roberto. "Aspectos da história econômica do café”. In: Revista do Arquivo Municipal. São Paulo: Prefeitura do Município de São Paulo, 1940, v. 65

SOARES, José Julio. Idéas Cooperatistas. Belo Horizonte: Salesiano, 1914.

Sociedades cooperativas e o regime democrático: teoria e prática das instituições mutualistas acomodadas à legislação atual. Rio de Janeiro: s/n., 1955.

SINGER, P. “O Brasil no Contexto do Capitalismo Internacional (1889-1930)”. História Geral da Civilização Brasileira, v. III, 1985. 
SILVA, Giovane José da. O batismo de clio: catolicismo-social e história em Jonathas Serrano (1908-1931). São João Del Rei: UFSJ (Dissertação de mestrado), 2013.

SILVA, Ligia Osorio. Terras devolutas e latifúndio. Campinas: Ed. Unicamp, 2008.

SILVA, Sergio. Expansão Cafeeira e Origens da Industria no Brasil. São Paulo: AlfaOmega, 1995.

"Formas de acumulação e desenvolvimento do capitalismo no campo". In: Jaime PINSKY (Org.) Capital e trabalho no campo. São Paulo. Hucitec, 1977.

SOARES Jr, Rodrigo. Jorge Tibiriçá e sua Época. Rio de Janeiro: Cia Ed. Nacional., 1958.

SOBRINHO, A. Motta. A Civilização do Café (1820-1920). São Paulo: Brasiliense, 1978,

STEIN, Stanley J. Grandeza e Decadência do Café no vale do Paraíba. São Paulo: Brasiliense, 1961.

SCHULZ, John. A Crise Financeira da Abolição 1875-1901. São Paulo: Edusp, 1996.

SCHWARTZ, Stuart B. Segredos internos: engenhos e escravos na sociedade colonial, 1550-1835Stuart B. Schwartz. São Paulo: Cia. das Letras, 2011.

TANNURI, Luis Antônio. O Encilhamento. São Paulo: Hucitec-Funcamp, 1981

TAUNAY, Afonso d'Escragnolle. Pequena história do café no Brasil (1727-1937)

Rio de Janeiro: Dep. Nacional do Café, 1945.

TELLES, Augusto C da Silva. Cafe: defenda-se a lavoura. Rio de Janeiro: Officinas Graphicas do Jornal, 1919.

TEODORO, R. S. O Crédito no mundo dos senhores do café: Franca 1885-1914. Campinas: UNICAMP (Dissertação de Mestrado), 2006.

"Crédito e Expansão da Cafeicultura: o caso do município paulista de Franca 1887-1914". Heera: História Econômica e Economia Regional Aplicada, v. 01, p. 01-23, 2006.

TESSARI, Cláudia Alessandra. Braços para colheita: sazonalidade e permanência do trabalho temporário na agricultura paulista (1890-1915). Campinas: UNICAMP, 2010.

TOPOROWSKI, Jan. "La banque mutuelle: de l'utopie au marché des capitaux, le cas britannique". Revue d'economie financiere, v. 67, n. 3, p. 45-55, 2002.

TORELI, Leandro Salman. Defesa do café e a política cambial: os interesses da elite paulista na primeira república (1898-1920). Campinas: IE/Unicamp (Dissertação de Mestrado), 2004.

TORRES, Manuel Martins. Lei Hypothecaria. Rio de Janeiro: Livraria Cruz Coutinho, 1875.

TOSI, Pedro Geraldo, Rogério Naques FALEIROS and Rodrigo da Silva TEODORO. "Crédito e pequena cafeicultura no oeste paulista: Franca/SP 1890-1914."Revista Brasileira de Economia, v. 3, n. 61, 2007, p. 405-426.

"Fragmentos de um modelo: pequenas lavouras de café e acumulação de capitais. Franca/São Paulo, 1890-1914." História. São Paulo 24.2 (2005): 291-327.

TOSI, Pedro Geraldo, Rogério Naques FALEIROS, and Rodrigo FONTANARI. "Modalidades e hierarquias do crédito na cafeicultura paulista (1889-1930)."Revista Brasileira de Economia, v. 4, n. 65, 2011, p. 401-412.

TULCHIN, Joseph S. "El Crédito Agrário em La Argentina, 1910-1926". Desarollo Económico. v. 18, n. 71, 1978, p. 381-408.

TOPIK, Steven. A Presença do Estado na Economia Política do Brasil de 1889 a 1930. Rio de Janeiro: Ed. Record, 1987.

TAUNAY, Affonso de E. História do café no Brasil. Rio de Janeiro: INC, 1941 v. 6-11 Pequena História do Café no Brasil (1727-1937). Rio de Janeiro: DNC, 1945. 
História Colonial da Cidade de São Paulo no Século XIX. São Paulo: Arquivo Público do E. de S. Paulo, 1956.

WHITAKER, José Maria. Letras de cambio. São Paulo: Saraiva, 1932.

O Milagre de Minha Vida. S. Paulo: Hucitec, 1978.

VEIGA, Didimo Agapito da. Direito hypothecario: commentario ao decreto n.169A de 19 de janeiro de 1890. Rio de Janeiro: Laemmert, 1899.

VEIGA FILHO, João Pedro. Estudos Econômico e Financeiros Sobre o Estado de São Paulo. São Paulo: Diario Official, 1896.

VIDAL, Rafael de A. Sampaio. Organização commercial da defesa do café - armazéns gerais e seus títulos (warrant, etc.): lei vigente e comentário. São Paulo: Duprat, 1906.

VILLELA, Annibal V. e Wilson Suzigan. Política do Governo e Crescimento da Economia Brasileira, 1889-1945. Rio de Janeiro: IPEA/INPES, 1973.

VOGT, Olgário Paulo \& Roberto RADÜNZ. "De matriz conservadora a uma postura progressista: catolicismo social no Rio Grande do Sul - RS - Brasil". Redes, v. 18, n. 2, p. 124-141, 2013.

ZIOLI, Miguel. Política com café no oeste do estado de São Paulo, Bento de Abreu Sampaio Vidal (1872-1948). Assis: UNESP-FCLA (Dissertação de mestrado), 2006. 
Nosso corpo documental compõe-se de fontes discursivas, principalmente, periódicos, publicação editorial contemporânea, relatórios oficiais e discussões parlamentares; fontes cartoriais e contábeis, tais como atas, estatutos, leis, balanços e relatórios fiscais e fontes judiciais como o processo de falência da Sociedade Incorporadora.

A respeito das fontes discursivas, utilizamos: matérias publicadas em periódicos que cobriram desde as discussões sobre a necessidade de se introduzir cooperativas de crédito em São Paulo, passando pela primeira experiência de organização de um Banco de Custeio Rural em Capivari e Ribeirão Bonito, em 1903, até as discussões em torno da falência da Sociedade Incorporadora em 1914 ${ }^{378}$; analisamos também o discurso oficial contido nos relatórios dos secretários de Fazenda (1890-1915) e Agricultura de São Paulo (1896-1914), além dos relatórios dos ministros da Fazenda (1896-1898), Indústrias e Obras Públicas (1897) e Agricultura (1909-1915), assim como as mensagens enviadas pelos presidentes do estado ao Congresso Legislativo entre 1896 e $1914^{379}$. Outras fontes de enorme importância para compreender os debates ocorridos foram as de natureza legislativa, compostas pelos anais da Câmara e do Senado paulista e projetos de lei que tramitavam no Congresso Legislativo que diziam respeito ao nosso objeto ${ }^{380}$.

Para compreender o modo de funcionamento estatutário e legal dos Bancos de Custeio Rural, utilizamos atas e estatutos da Sociedade Incorporadora e dos dez primeiros bancos autorizados a funcionar entre 1907 e $1908^{381}$. Enquanto na quantificação das operações desses bancos, utilizamos os balanços publicados no Anuário Estatístico

\footnotetext{
378 Os jornais O Estado de São Paulo e O Comércio de São Paulo foram fotografados ou fichados ainda durante a graduação no acervo do Arquivo Público do Estado de São Paulo e na biblioteca da Faculdade de Direito da USP. O jornal O Atalaya, encontramos no Arquivo Municipal de Jaboticabal, enquanto os jornais Correio Paulistano, O Paiz, A Platea, Correio do Sertão foram consultados na Hemeroteca Digital da Biblioteca Nacional.

${ }^{379}$ Esta documentação foi consultada em acervos diversos: os relatórios estaduais estão espalhados pelas bibliotecas da Faculdade de Direito (USP) e Florestan Fernandes (FFLCH-USP), Museu Paulista, Museu Republicano, Arquivo Público do Estado de São Paulo, enquanto os relatórios produzidos pelo governo federal estão disponíveis no site do Center for Research Libraries (Fundo: Brazilian Government Document Digitization Project).

${ }^{380}$ Principalmente o Projeto s/n, de 1903, que versava sobre as "medidas destinadas a minorar os efeitos da crise da lavoura de café" e que resultaria na aprovação da Lei no 866, de 7 de abril de 1903 e, principalmente, o Projeto $n^{\circ} 40$, de 1903, que resultaria na aprovação da Lei $n^{\circ} 1.062$ de 29 de dezembro de 1906, que estabelecia as bases estatutárias aos Bancos de Custeio Rural para que pudessem receber um auxílio em apólices da dívida pública. O levantamento desse material foi realizado com o Acervo Histórico da Assembleia Legislativa do Estado de São Paulo (ALESP).

${ }^{381} 1^{\circ}$ Registro de Imóveis da Capital. Arquivo Público do Estado de São Paulo.
} 
do Estado de São Paulo ${ }^{382}$ e os relatórios anuais da comissão responsável pela fiscalização dos Bancos de Custeio Rural, esta última, além de nos fornecer dados contábeis que nos permitiram cotejar com os dos balanços, trouxeram detalhes sobre os contratos de empréstimos realizados. Enquanto isso, o processo de falência da Sociedade Incorporadora constituiu-se em uma de nossas principais fontes para reconstrução do modo de funcionamento dos Bancos de Custeio Rural, pois, enquanto os relatórios fiscais nos permitiram reconstituir a relação dos Bancos de Custeio com os fazendeiros associados, o processo de falência nos possibilitou compreender as relações entre dos BCRs com a Sociedade Incorporadora e desta com o sistema de crédito comercial e bancário $^{383}$.

O relatório de falência, aliás, mostrou-se uma documentação privilegiada, ainda muito pouco utilizada, diga-se de passagem, pois pudemos verificar que ela permite ao historiador de empresas algo semelhante àquilo que o inventário post mortem representou para a pesquisa dos negócios realizados por particulares. Na falência, assim como na partilha, as informações não são expostas de acordo com a vontade do falecido/falido e sim conforme as necessidades dos diversos interessados em seu espólio. Assim, as contas da empresa são expostas com o máximo de veracidade, permitindo, por exemplo, que desfalques e operações escusas apareçam mesmo quando habilmente disfarçadas nos balanços contábeis, geralmente para o estarrecimento dos interessados. Essa documentação não nos serviu apenas para cotejar balanços fraudulentos, pois, em nosso caso, ela demonstrou grande valia para a compreensão das práticas comerciais, creditícias e bancárias do período e, no caso da Sociedade Incorporadora, nos possibilitou compreender o seu complexo modo de operação por meio de operações de desconto e redesconto de letras de câmbio que envolviam, além dos Bancos de Custeio Rural, firmas comissárias e bancos.

\footnotetext{
${ }^{382}$ Esta documentação foi consultada no Arquivo Público do Estado de São Paulo e, posteriormente, foi digitalizada pela Biblioteca do Ministério da Fazenda no Rio de Janeiro (BMF/RJ), sendo disponibilizada no site Memória Estatística do Brasil (http://memoria.org.br).

383 Este documento é composto por um processo principal com três volumes e dezenas de processos paralelos, chamados "reclamações reivindicatórias", em que cada interessado no espólio da empresa expõe seus motivos e apresenta as provas que lhe permitiriam participar da distribuição dos bens da massa falida. Os processos foram consultados no Arquivo Histórico do Tribunal de Justiça do Estado de São Paulo.
} 